Jane Raquel Silva de Oliveira

\title{
Pesquisa participativa na elaboração de um material didático sobre comunicação e expressão em linguagem científica para estudantes de graduação em Química
}

Dissertação apresentada ao Instituto de Química de São Carlos, da Universidade de São Paulo, para a obtenção do título de Mestre em Ciências (Química Analítica)

Orientadora: Profa. Dra. Salete Linhares Queiroz 


\section{DEDICATÓRIA}

Dedico este trabalho a meu avô Pedro Mendes

(in memorian), cujo caráter forte, mas por vezes sensível, serviu de base para minha formação. 


\section{AGRADECIMENTOS}

A Deus, o melhor dos mestres, pela vida, a eterna "sala de aula".

A minha família pelo constante apoio e estímulo ao meu crescimento - mesmo à distância - durante todos estes anos.

A minha orientadora, Salete Linhares Queiroz, pelo "sim" quando tudo tendia a um “não", pela cuidadosa condução deste trabalho e pelas importantes lições que foram além do desenvolvimento de trabalhos científicos.

A meu namorado, Guilherme, pela paciência durante as fases mais difíceis, pelo constante incentivo e pelo carinho doado incondicionalmente todos os dias.

Aos amigos do Edifício dos Pinhais, minha "segunda família", pela confortável acolhida e por tornarem os dias longe de casa mais alegres e descontraídos.

Às amigas distantes, Venina, Fernanda, Flávia, Olívia, Renata, Jaqueline, pelos pequenos gestos de apoio e carinho, constantemente presentes em $e$-mails - mesmo sabendo que eu não responderia à maioria deles.

Aos colegas da farmácia, pela convivência agradável, pelas preciosas lições de vida colhidas no dia-a-dia e pelo importante aprendizado do trabalho em grupo.

Aos colegas do grupo de Pesquisa em Ensino de Química, Cristiane, Luciana Sá, Gelson, Ribeiro, Luciana Massi, Daniel, Luciane Jatobá, pelos agradáveis momentos na "salinha", apesar do pouco tempo disponível para manter um convívio mais freqüente e pelos conhecimentos compartilhados nos seminários do grupo. 


\section{AGRADECIMENTO ESPECIAL}

Aos alunos de graduação e de pós-graduação e ao professor que participaram nas várias etapas deste trabalho como sujeitos de pesquisa, cujos nomes, por questões éticas, não mencionaremos aqui e sem os quais não seria possível a realização desta pesquisa participativa.

Agradecemos, portanto, a tais sujeitos pelo tempo generosamente dedicado nas vindas às reuniões de grupos, pela cuidadosa leitura de todos os textos, pelas críticas e sugestões gratuitamente fornecidas durante o desenvolvimento do material e, sobretudo, pelo apoio e estímulo presentes em todas as etapas deste estudo. 


\section{RESUMO}

Diante do acentuado crescimento da comunicação científica, tanto em número de artigos publicados em revistas quanto em importância para aqueles que se dedicam à área de Ciências, a capacidade de expressão em linguagem científica tem se tornado uma habilidade valiosa para a formação do graduando em Química. Com o intuito de contribuir no desenvolvimento de tais habilidades, objetivamos neste trabalho elaborar e validar um material didático sobre o tema em foco destinado a alunos de graduação em Química. A elaboração do material foi realizada baseando-se nos fundamentos da pesquisa participativa. Através de reuniões de grupo com alunos de graduação, de pós-graduação e um docente da área de Química foram planejados os objetivos, as estratégias e o conteúdo do material, bem como sua forma de apresentação e organização. Depois de concluído, o material foi validado por novos sujeitos através de um questionário de avaliação. A partir dos debates em grupo foi possível analisar as diferentes visões dos sujeitos da pesquisa sobre diversos temas relacionados à comunicação científica no cenário atual. Vários aspectos do material produzido foram consequiências das idéias, críticas e sugestões do grupo durante as reuniões. Desta forma, foi possível observar constantes transformações durante sua elaboração, bem como a inclusão de novos conteúdos e abordagens ao longo do texto. Portanto, a pesquisa participativa influenciou consideravelmente o desenvolvimento do referido material, demonstrando ser um importante modelo de construção conjunta do conhecimento. As respostas fornecidas ao questionário de avaliação do material demonstraram sua boa conceituação entre os novos sujeitos da área de Química. Desta forma, foi possível perceber que o material pode ser um importante instrumento didático de apoio para o desenvolvimento de habilidades de comunicação e expressão em linguagem científica. 


\section{ABSTRACT}

Considering the accentuated growth of the scientific communication, so much in number of papers published in periodicals as in importance for those who are devoted to the area of Sciences, the capacity of expression in scientific language has been presented as a valuable ability for the formation of the graduation student in Chemistry. With the intention of contributing in the development of such abilities, in the present work, we aimed at elaborating and validating a didactic material about the theme in focus destined for graduation students in Chemistry. The elaboration of the material was accomplished basing on the foundations of the participatory research. Through group meetings with graduation students, masters degree students and a professor of Chemistry, the objectives, the strategies and the contents of the material were drifted, as well as their presentation form and organization. After having ended, the material was validated by new subjects through an evaluation questionnaire. Starting from the group debates, it was possible to analyze the different visions of the subject of the research about several themes related to the scientific communication in the current scenery. Several aspects of the produced material were consequences of the ideas, criticism and suggestions of the group during the meetings. This way, it was possible to observe constant transformations during their elaboration, as well as the inclusion of new contents and approaches along the text. Therefore, the participatory research influenced the development of the referred material considerably, demonstrating to be an important model of united construction of the knowledge. The answers supplied to the evaluation questionnaire of the material demonstrated their good concept among the new subject of the area of Chemistry. This way, it was possible to notice that the material can be an important didactic instrument of supporting for the development of communication abilities and expression in scientific language. 


\section{LISTA DE ILUSTRAÇÕES}

Figura 1 - A espiral da cultura científica: modelo de classificação, difusão e evolução do conhecimento científico, segundo Vogt (2003).....

Quadro 1 - Falas dos sujeitos nas reuniões e suas conseqüências sobre o título do material.

Quadro 2 - Falas dos sujeitos nas reuniões e suas conseqüências sobre os títulos de alguns tópicos do material.

Quadro 3 - Falas dos sujeitos nas reuniões e suas consequiências sobre a elaboração da seção Apresentação do material.

Quadro 4 - Falas dos sujeitos nas reuniões e suas consequiências sobre a abordagem de questões éticas no tópico Considerações sobre a Comunicação Científica do material

Quadro 5 - Falas dos sujeitos nas reuniões e suas conseqüências sobre a seção Relatórios do material.

Quadro 6 - Falas dos sujeitos nas reuniões e suas consequiências sobre a utilização de exemplos extraídos de revistas da área de Química no material

Quadro 7 - Falas dos sujeitos nas reuniões e suas consequiências sobre a elaboração de exemplos no material.

Quadro 8 - Falas dos sujeitos nas reuniões e suas conseqüências na elaboração da seção

Introdução do material.

Quadro 9 - Falas dos sujeitos e suas conseqüências sobre a descrição de apud no material.

Quadro 10 - Falas dos sujeitos e suas consequiências sobre a elaboração do tópico Algumas Características da Linguagem Científica do material.

Quadro 11 - Falas dos sujeitos e suas consequiências sobre a elaboração da seção $O s$

Tempos Verbais nos Textos Científicos no material 


\section{LISTA DE TABELAS}

Tabela 1 - Resumo das reuniões de grupo, ocorridas durante a fase de análise crítica dos problemas considerados prioritários, para elaboração participativa de um material didático sobre comunicação científica.....

Tabela 2 - Resumo das reuniões de grupo, ocorridas durante a fase de programação $e$ execução de um plano de ação, para elaboração participativa de um material didático sobre comunicação científica.................................................................

Tabela 3 - Categorias de temas relacionados à comunicação científica e número de citações entre os sujeitos de pesquisa.

Tabela 4 - Distribuição percentual das respostas fornecidas pelos oito sujeitos ao questionário de avaliação do material (etapa de validação)............................... 
RESUMO

ABSTRACT

LISTA DE ILUSTRAÇÕES

LISTA DE TABELAS

1 INTRODUÇÃ

1.1 EVOLUÇÃO DA COMUNICAÇÃO CIENTÍFICA ........................................ 12

1.2 DISCIPLINAS DE GRADUAÇÃO QUE VISAM O DESENVOLVIMENTO DE HABILIDADES DE COMUNICAÇÃO EM LINGUAGEM CIENTÍFICA ............ 22

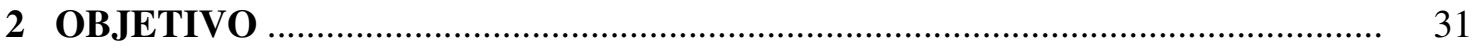

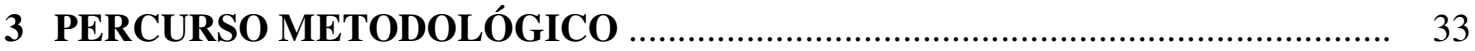

3.1 REFERENCIAL TEÓRICO ADOTADO PARA O DELINEAMENTO DO PERCURSO METODOLÓGICO: PESQUISA PARTICIPATIVA _......................... 33

3.2 METODOLOGIA DA PESQUISA E FORMA DE COLETA DE DADOS ........... 36

3.2.1 Montagem Institucional e Metodológica ................................................... 37

3.2.2 Estudo Preliminar Provisório ………….................................................... 38

3.2.3 Análise Crítica dos Problemas Considerados Prioritários ............................... 39

3.2.4 Programação e Execução de um Plano de Ação ............................................. 42

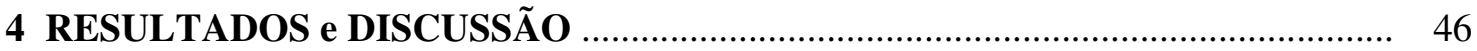

4.1 A COMUNICAÇÃO CIENTÍFICA NA VISÃO DOS SUJEITOS DA

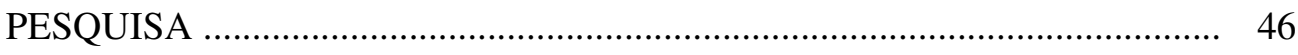

4.1.1 A Importância da Comunicação Científica ................................................ 49

4.1.2 O Relatório de Laboratório ..................................................................... $\quad 50$

4.1.3 Apresentações Orais e Escrita Científica ..................................................... 53 
4.1.4 Marketing e Ética em Comunicação Científica ........................................ 57

4.1.5 A Evolução da Ciência e sua Especialização ................................................... 59

4.2 DE COMO AS DISCUSSÕES EM GRUPO SE REFLETIRAM NA

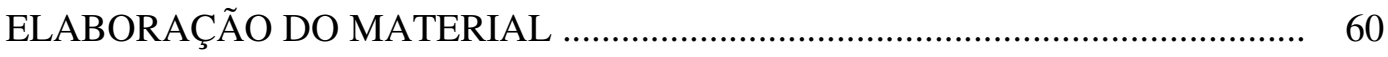

4.2.1 Considerações Sobre o Título ................................................................ 61

4.2.2 Considerações Sobre os Títulos de Alguns Tópicos .................................... 62

4.2.3 Considerações Sobre a Seqüência dos Tópicos ........................................ 63

4.2.4 Considerações Sobre a Seção Apresentação ................................................... 65

4.2.5 Considerações Sobre Marketing e Ética .................................................... 66

4.2.6 Considerações Sobre o Relatório de Laboratório ....................................... 67

4.2.7 Uso de Revistas para Obtenção dos Exemplos ......................................... 68

4.2.8 Considerações Sobre a Seção Introdução ................................................. 71

4.2.9 Considerações Sobre a Descrição de Apud ….............................................. 72

4.2.10 Considerações Sobre Características da Linguagem Científica …................. 73

4.2.11 Considerações Sobre os Tempos Verbais nos Textos Científicos ................ 75

4.3 CARACTERÍSTICAS GERAIS DO MATERIAL …........................................ 76

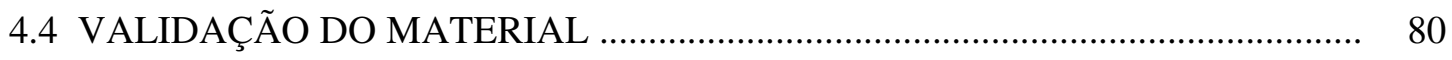

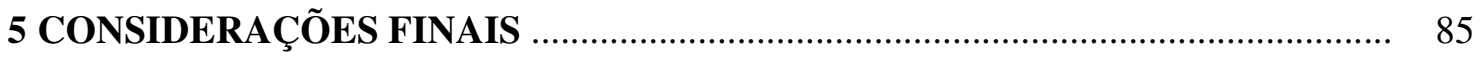

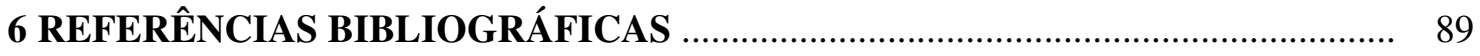

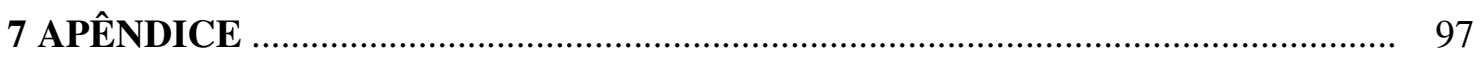




\section{INTRODUÇÃo}

Desde a publicação, em março de 1665, do primeiro periódico da área de Ciências Naturais, o Philosophical Transactions, a comunidade científica tem presenciado o crescimento rápido do número de publicações científicas (MEADOWS, 1999). Além disso, é crescente também o número de artigos submetidos à publicação em muitos periódicos. Este aumento, bem como a disponibilidade da informação científica, de certa forma está ligado ao avanço na comunicação eletrônica e a difusão da tecnologia computacional, o que revolucionou a tradicional publicação em jornais. Esta revolução na comunicação científica teve início na metade do século XIX e culminou com o extraordinário progresso nas telecomunicações e na tecnologia computacional nos últimos anos do século XX (GARSON, 2004). Tais constatações demonstram que a comunicação científica tem crescido rapidamente não apenas em número, mas também em importância para aqueles que se dedicam à Ciência.

Diante desse quadro, o desenvolvimento das habilidades de comunicação em linguagem científica tem sido considerado como altamente desejável na formação dos alunos em cursos de Ciências (LUZ JÚNIOR et al., 2004). Desta forma, juntando-se ao rol de pesquisadas direcionadas à investigação de questões que possam vir a contribuir para o desenvolvimento dessas habilidades, neste trabalho, através da realização de uma 
investigação, pautada nos princípios da pesquisa participativa (BRANDÃO, 1999), foi produzido e validado um material instrucional dirigido ao aprimoramento das habilidades de comunicação em linguagem científica de alunos de graduação em Química.

Apresenta-se a seguir algumas considerações sobre a evolução da comunicação científica e sobre atividades realizadas em disciplinas de cursos superiores de Química voltadas ao aprimoramento das referidas habilidades. Tais considerações foram úteis para o desenvolvimento do material instrucional em questão e apontam para a necessidade da realização de ações nos cursos de graduação em Química que favoreçam o aprimoramento das habilidades de comunicação em linguagem científica dos estudantes.

\subsection{EVOLUÇÃO DA COMUNICAÇÃO CIENTÍFICA}

Desde há muitos anos os cientistas têm se preocupado não só com a geração do conhecimento, mas também com a sua divulgação. Embora não se possa afirmar com exatidão quando se iniciou a comunicação científica, pode se dizer que sua origem está diretamente ligada à própria produção da Ciência.

Segundo Meadows (1999), a comunicação científica na forma oral já ocorria na Grécia nos séculos V e IV a.C. Nesta época os gregos reuniam-se na Academia, em Atenas, para tratar de questões filosóficas Os gregos foram ainda os precursores da comunicação científica na forma escrita: os debates de Aristóteles, por exemplo, foram conservados em manuscritos e copiados repetidas vezes, influenciando a cultura árabe e a européia, sobretudo durante o Renascimento entre os séculos XIV e XVI.

A introdução da imprensa na Europa no século XV foi um fator de grande importância para a comunicação científica, pois facilitou a difusão das informações e impulsionou as publicações científicas. A possibilidade de produção de textos impressos fez com que a 
produção média de livros aumentasse consideravelmente. Embora muitos desses livros não versassem especificamente sobre Ciência, o livro impresso foi também um importante veículo de transmissão dos resultados da pesquisa científica. Um dos exemplos mais marcantes dessa época foi a publicação, em 1543, do De revolutions orbitum coelestium [Das revoluções dos corpos celestes], de Copérnico - obra fundadora da Astronomia moderna.

Durante o século XVII e XVIII alguns manuscritos científicos eram produzidos, sobretudo na forma de cartas que circulavam entre um grupo reduzido de pesquisadores que debatiam sobre temas comuns. No entanto, a necessidade de difundir as novas idéias e descobertas a um grupo cada vez maior levou à criação, na segunda metade do século XVII, das primeiras revistas científicas. Sua origem está ligada à fundação, em 1662, da Royal Society, em Londres. Tal instituição, além de reuniões onde eram discutidas questões filosóficas, mantinha membros no estrangeiro, que eram responsáveis por enviar relatórios sobre os progressos científicos ocorridos em seus países. Todas as correspondências eram enviadas a um secretário geral da sociedade, Henry Oldeburg, que, ao enviar cartas para outros membros, tanto do país como do estrangeiro, atuava como um centro difusão de novas idéias e pesquisas. Como o volume de tais cartas aumentava consideravelmente, optou-se por fazê-las como uma publicação impressa. Assim, em março de 1665, o conselho da Royal Society determinou que o Philosophical Transactions, preparado por Oldenburg, fosse impresso na primeira segunda-feira de cada mês. O texto seria antes revisto por alguns de seus membros e julgado pelo conselho, aprovando-o, ou não. Portanto, o Philosophical Transactions é considerado o precursor dos periódicos da área de Ciências Naturais.

O formato de apresentação dos artigos nos periódicos evoluiu gradualmente ao longo dos anos. Os títulos dos primeiros artigos, por exemplo, não ofereciam informações tão detalhadas sobre seu conteúdo como os títulos dos artigos publicados atualmente. Em geral eram bem mais curtos, semelhantes aos títulos de livros atuais. Além disso, os artigos tinham 
geralmente um único autor e não apresentavam um formato rígido como os exigidos pela maioria dos periódicos modernos. Outras características da evolução do formato de apresentação dos artigos científicos podem ser observadas até mesmo em periódicos nacionais. Os artigos publicados na revista Química Nova há 30 anos, por exemplo, não apresentavam o Resumo (Abstract) em seus textos. Ademais, não havia um formato uniforme (divisão em Introdução, Parte Experimental, Resultados e Discussão) estabelecido para apresentação do manuscrito. Em geral cada autor organizava seu texto de forma livre.

A evolução da comunicação científica foi ditada pelo crescimento da comunidade científica ao longo dos séculos. Esse crescimento pode ser verificado através do número de doutores formados anualmente. Os programas de pós-graduação em Química do Brasil, por exemplo, entre 1983 e 1984 formaram 75 doutores. Entre 2001 e 2003 esse número passou para 890 doutores formados. Como conseqüência deste crescimento, o número de trabalhos publicados em revistas especializadas também aumentou. Entre 1983 e 1984 foram publicados na área de Química em revistas científicas 477 artigos, e entre 2001 e 2003, um total de 6.565 artigos (GAMA; FERREIRA, 2004). Além disso, o número de publicações por pesquisador também cresceu. Portanto, conclui-se que o número de artigos publicados aumentou em proporção ainda maior que o crescimento da própria comunidade científica, no Brasil. Isto provavelmente se verifica no exterior de forma geral.

Outra conseqüência imediata do crescimento da comunidade científica foi o aumento do número de títulos de periódicos, compartimentando áreas específicas do conhecimento. Além disso, o volume de informações em cada periódico também sofreu transformações: mais fascículos de cada periódico passaram a ser publicados por ano e o número de páginas em cada fascículo também aumentou. Na área de Ciência e Tecnologia podemos citar como exemplo a revista Química Nova que há 30 anos apresentava periodicidade trimestral e hoje é bimestral. Além de publicar mais volumes por ano, a mesma revista aumentou ao longo dos 
anos também o número de páginas publicadas: na década de 80 cada volume da Química Nova possuía, em média, 50 páginas e, na atual década, esse número está em cerca de 200 páginas por volume.

Este crescimento rápido do número de publicações científicas pode ser observado também em diversos periódicos internacionais. O número de artigos submetidos à publicação no Journal of the American Chemical Society, por exemplo, passou de cerca de 4.000 artigos no ano de 1994 para 8.000 em 2004 (JACS FACTS, 2006). Diante da expansão de informações publicadas nos periódicos, o número de livros que versam sobre temas científicos também cresceu significativamente.

A forma encontrada pela comunidade científica para lidar com o grande número de informações foi através da especialização. Desta maneira, os cientistas foram cada vez mais se aprofundando em uma área da Ciência e, mais adiante, em assuntos ou linhas de pesquisa dentro de uma mesma área. Ou seja, tornava-se extremamente difícil a um cientista ler e acompanhar todo o progresso ocorrido em Biologia, Física, Química e Matemática, por exemplo. Alguns cientistas passaram a ser estudiosos da área de Química. Posteriormente, outros cientistas, diante do grande número de informações na área Química, optaram, por exemplo, por direcionar mais especificamente seus estudos à Química Orgânica, ou em subáreas desta, tais como Síntese de Compostos Orgânicos, Produtos Naturais, Fármacos Orgânicos, Polímeros etc. A especialização ocorrida nas comunidades científicas se refletiu também nos títulos dos periódicos. Surgiram, assim, periódicos cujos artigos abordam assuntos cada vez mais específicos. Hoje temos, por exemplo, periódicos como o Nitric Oxide, destinado especificamente a publicar trabalhos de pesquisas relacionadas ao óxido nítrico.

Em face à grande quantidade de literatura científica, foram criadas, como forma de organizar e facilitar pesquisas bibliográficas, as publicações de resumos e índices. Uma das 
mais marcantes publicações dessa categoria para a área de Química é o Chemical Abstracts, criado em 1907 pela American Chemical Society, o qual pode ser consultado atualmente em sua tradicional versão impressa ou em sua versão eletrônica (disponível através do software SciFinder Scholar). Cabe ressaltar que à medida que aumentavam as publicações primárias (como os artigos), conseqüentemente cresciam as publicações secundárias (como livros) e as publicações terciárias (como os resumos). É de se concluir, portanto, que cada vez mais a comunidade científica detinha a árdua tarefa de localizar, em meio às mais variadas publicações, as informações que lhe interessavam.

O surgimento e expansão dos computadores contribuíram significativamente para facilitar a localização da literatura científica e aprimorar a comunicação. O uso dos computadores na comunicação científica data da década de 60, embora apenas na década de 80, com produção de computadores menores e com maior capacidade de armazenamento de dados e elaboração de textos e elementos gráficos, esse recurso passou a ser amplamente aceito e utilizado por vários pesquisadores (PACKER et al., 1998). A localização de publicações científicas foi realizada desde o início através de palavras-chave. Inicialmente, era possível localizar trabalhos apenas através de palavras contidas em seus títulos. À medida que os computadores avançavam em tecnologia e capacidade de armazenamento de informações, as buscas através das palavras-chave passaram a abranger o resumo do trabalho. Atualmente, as bases de dados de pesquisa bibliográfica localizam trabalhos até mesmo através de palavras contidas em seu texto integral, bem como através do nome dos autores, ano de publicação, título dos periódicos etc.

A criação e a rápida universalização da Internet contribuíram decisivamente para integrar e divulgar as publicações científicas em todo o mundo. Surgiram as bases de dados on-line, onde são reunidas publicações de diversos periódicos. Aos poucos, os pesquisadores passaram a localizar com frequiência artigos em meios eletrônicos. Atualmente, algumas bases 
de dados científicas, como a SCOPUS, da Editora Elsevier, dispõem de grandes acervos. Esta última tem um acervo de cerca de 14.000 periódicos, cujos artigos podem ser facilmente localizados e oferece ao usuário acesso aos resumos e textos completos dos artigos. Outro recurso disponível através da Internet é a submissão de trabalhos à publicação via on-line, bem como submissão de resumos para congressos e outras reuniões científicas.

Diante da expansão da comunicação e da difusão do conhecimento, alguns autores preocuparam-se em discutir como a literatura científica é produzida e difundida, não apenas entre os pesquisadores (pares), mas também em diversos meios da sociedade. Carlos Vogt (2003), em seu trabalho A Espiral da Cultura Científica, analisa a dinâmica do processo de produção literária do conhecimento científico - ou cultura científica, como é chamada por ele - como uma espiral. Segundo este modelo, o conhecimento científico produzido circula, através de diversos meios de comunicação, entre pesquisadores, estudantes, jornalistas e a sociedade como um todo. A Figura 1 ilustra o modelo de espiral da cultura científica sugerido por Vogt.

Neste modelo, o autor inicialmente agrupa a cultura científica relacionada à produção e difusão da ciência entre os pares, onde cientistas produzem a literatura científica para outros cientistas ( $1^{\circ}$ quadrante $)$. Estão envolvidas neste primeiro processo de produção do conhecimento científico as universidades, centros de pesquisa, agências de fomento à pesquisa, revistas científicas etc. Em um segundo plano ( $2^{\circ}$ quadrante), agrupam-se os trabalhos relacionados ao ensino de ciências e a formação de cientistas, onde os cientistas e professores, ligados às universidades e instituições de ensino médio, levam a cultura científica a estudantes. Em um outro estágio deste caminho ( $3^{\circ}$ quadrante), o autor agrupa as atividades de ensino para Ciência, no qual tanto cientistas, quanto professores, diretores de museus levam a cultura científica para os jovens de um modo geral. No último estágio ( $4^{\circ}$ quadrante) - mas não o fim do percurso - observa-se as atividades de divulgação científica, onde 
jornalistas e cientistas, através de revistas de divulgação científica ou de páginas de jornais voltadas para o tema, divulgam a cultura científica à sociedade como um todo.

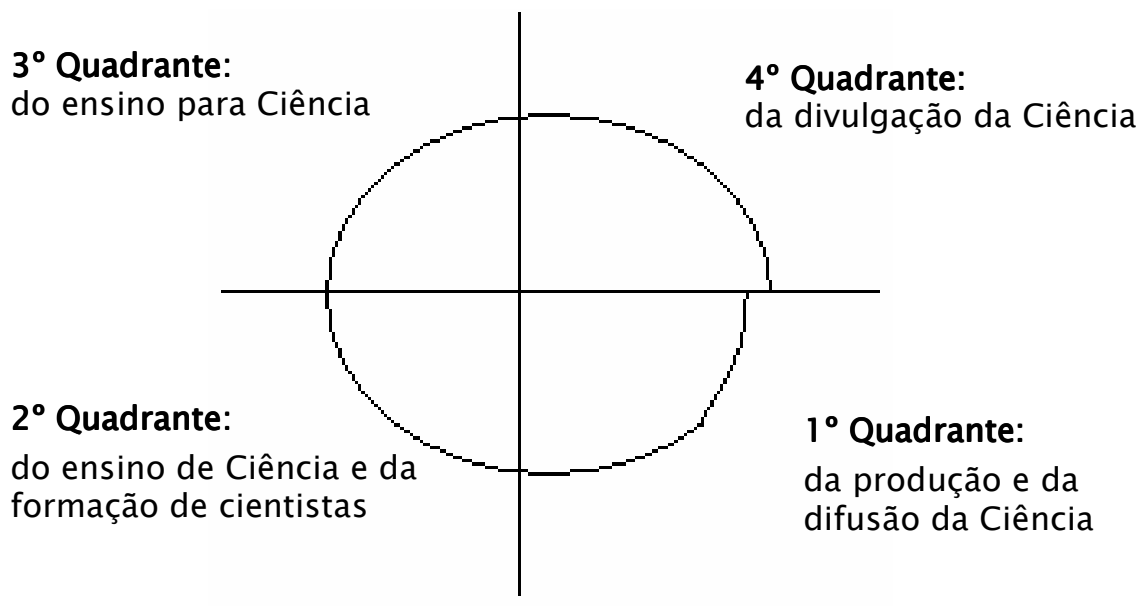

Figura 1. A espiral da cultura científica: modelo de classificação, difusão e evolução do conhecimento científico, segundo Vogt (2003).

Um fato notório no modelo proposto por Vogt é que a cultura científica circula, mas não volta para o mesmo ponto. Por isto é chamada de espiral e não de círculo. Afinal, ao completar o percurso, o conhecimento científico já evoluiu e, portanto, aqueles que produzem, ensinam ou divulgam a cultura científica não podem partir de um mesmo ponto do conhecimento. É a evolução natural da Ciência.

Com o decorrer do tempo e em face ao grande número de publicações lançadas continuamente no meio científico, surgiu a necessidade de se avaliar a qualidade da literatura científica produzida. Para analisar aspectos referentes à geração, propagação e emprego das publicações científicas são utilizadas informações sobre a literatura científica mundial, produzidas anualmente, contidas em bancos de dados. Pinto e Andrade (1999), em artigo publicado na revista Química Nova, discutem como é calculado e o que significa o Fator de Impacto de revistas científicas. 
O Institute for Scientific Information (ISI) fornece o principal banco de dados utilizado para avaliar as publicações científicas. Esta avaliação é realizada através do Fator de Impacto - também chamado Índice de Impacto - dos principais periódicos científicos indexados no ISI. O ISI publica o Science Citation Index, uma base que contém cerca de 5.330 revistas indexadas cobrindo 160 campos do conhecimento. Todas as informações são organizadas no sentido de revelar o número de citações dos artigos publicados no próprio periódico e nos demais, em determinado ano. As informações contidas no Science Citation Index são utilizadas para o cálculo do Fator de Impacto dos principais periódicos, cujos resultados são divulgados no Journal of Citation Reports (JCR), também publicado pelo ISI.

O crescimento das publicações, bem como a criação de sistemas de avaliação da literatura científica, demonstra que a comunicação científica tem adquirido, nos últimos anos, grande relevância não apenas para aqueles que fazem Ciência, mas também para as instituições que os abrigam. Uma das formas de avaliar o mérito de instituições de ensino e pesquisa é através das publicações de seus pesquisadores (ROSENFELDT, et al., 2000). Podemos citar como exemplo o sistema de avaliação dos programas de pós-graduação, criado pela CAPES (Coordenação de Aperfeiçoamento de Pessoal de Nível Superior) em 1976. Através de critérios estabelecidos para cada área, a CAPES avalia os programas de pósgraduação existentes nas instituições de ensino superior e fornece um conceito que varia de 1 a 7. Embora este sistema avalie outros aspectos como, por exemplo, a atividade docente, a CAPES também avalia o corpo docente "pelas publicações em periódicos internacionais de impacto elevado, participação em corpo editorial de periódicos e outras comissões acadêmicas, organização de congressos, convites para palestras, prêmios e publicações citadas internacionalmente" (CAPES, 2006).

Para os pesquisadores a publicação vem se tornando cada vez mais importante. Publicar pode significar possibilidades de crescimento, de reconhecimento nacional ou 
internacional, obtenções de bolsas de estudo, recursos financeiros para pesquisas etc. Ao submeter um projeto às agências de financiamento, por exemplo, é obrigatória a apresentação do currículo atualizado dos pesquisadores. A análise da produção científica, obviamente, é um dos critérios adotados na aprovação de recursos para projetos de pesquisa.

Cabe ainda mencionar outro programa governamental de estímulo à produção científica: a Bolsa de Produtividade em Pesquisa, do CNPq. Esta bolsa é concedida a pesquisadores em função do mérito e quantidade de suas publicações, sua capacidade de formar pesquisadores e qualidade do projeto apresentado. Os valores das bolsas são variáveis de acordo com a categoria do pesquisador, a qual está relacionada com sua qualificação, experiência e capacidade de produção científica.

Em suma, podemos afirmar que a comunicação científica vem se tornando, ao longo dos tempos, uma das moedas mais fortes do pesquisador. Quanto mais ele tem, mais terá meios para continuar produzindo. Infelizmente, às vezes fazer Ciência implica em uma busca por quantidade e nem sempre por qualidade. Nesse contexto, verifica-se na comunidade científica, ao longo da história, a preocupação com a qualidade dos escritos e a veracidade das informações descritas. Para evitar que textos científicos sem o devido mérito sejam publicados, foram desenvolvidos mecanismos de avaliação da qualidade dos escritos, bem como estabelecidos normas de conduta ética em comunicação científica.

Um dos exemplos mais recentes e que despertou ainda mais a preocupação da comunidade científica em relação à ética na comunicação científica foi a descoberta de falsos resultados sobre clonagem de células-tronco publicada na Science, umas das revistas científicas mais prestigiadas no mundo (BENÍTEZ-BRIBIESCA; MODIANO-ESQUENAZI, 2006). O autor do artigo sobre o assunto, o coreano Woo-Suk Hwang, era considerado uma referência mundial nas pesquisas em células-tronco e seus resultados tiveram repercussão espetacular no meio científico. Este episódio demonstra que as publicações científicas podem 
ser alvos de conduta ética inadequada. O caso Hwang levantou também questionamentos sobre o cenário atual da Ciência, em que a ética é freqüentemente confrontada com a competitividade.

Outras condutas antiéticas, por parte dos autores, podem ainda ser observadas em publicações científicas, como o plágio e a autoria inadequada de trabalhos (PESSANHA, 1998; RODE; CAVALCANTI, 2003).

Uma das formas mais primitivas - e ainda presente atualmente - de tentar avaliar a qualidade das publicações científicas é a avaliação por pares, em um sistema conhecido na comunidade científica como peer review ou referee system. O processo de avaliação de um trabalho científico é realizado através do editor e dos avaliadores (conhecidos no Brasil como referee, revisor ou assessor). Desta forma, cada trabalho submetido à publicação em periódicos é analisado pelo assessor que emite seu parecer sobre o trabalho recebido. Este parecer é enviado ao editor que promove o julgamento final do texto.

O sistema de avaliação por pares, no entanto, também é passível de condutas antiéticas. Por parte dos assessores podem ocorrer: emissão de parecer não verdadeiro, ou influenciado por interesses pessoais ou comerciais; retardo na apresentação do parecer, sem motivos coerentes ou para obter vantagens pessoais; ou ainda a apropriação de idéias do texto que esteja examinando. Uma das formas da comunidade científica tentar evitar tais distorções é a utilização de vários analisadores, bem como solicitar declarações de compromissos. Além disso, enviam-se todos os pareceres sobre o trabalho analisado aos demais assessores, como forma de promover o controle de um avaliador sobre outro (PESSANHA, 1998).

O caráter confidencial no processo de avaliação de um trabalho também é bastante discutido em ética científica. Embora o grau de confidencialidade seja variável entre os periódicos, via de regra, os avaliadores desconhecem os autores e vice-versa. É uma forma de 
tentar evitar que haja condutas antiéticas na emissão do parecer. No entanto, nem todos os periódicos adotam este sistema de avaliação conhecido como "avaliação às cegas".

Uma preocupação freqüente na comunidade científica é a proteção do conhecimento científico. Há anos, estabeleceu-se nos periódicos a descrição da data de recebimento do trabalho, como forma de identificar e julgar quem foi o primeiro a publicar um novo resultado de pesquisa. A criação de patentes também tem aumentado bastante nos últimos anos, como forma encontrada pelos pesquisadores de garantir o direito à propriedade intelectual.

A conduta inadequada na comunicação científica levou a comunidade a criar comitês de ética específicos para tratarem desse tema. Em 1990, foi criado nos Estados Unidos o Comitê de Integridade Científica. A França criou em 1994 o Comitê de Ética para as Ciências do Centre National pour la Recherche Scientifique. Embora menos freqüente na área Química, vale ainda lembrar a existência de comitês e procedimentos especiais para a realização de pesquisas envolvendo seres humanos os animais de laboratório. E por fim, a preocupação ecológica também tem sido alvo de cuidados durante a realização de pesquisa de campo em ambientes de preservação ambiental, bem como a coleta de amostras em áreas de florestas, rios ou mares.

\subsection{DISCIPLINAS DE GRADUAÇÃO QUE VISAM O DESENVOLVIMENTO DE HABILIDADES DE COMUNICAÇÃO EM LINGUAGEM CIENTÍFICA}

Tendo em vista os aspectos anteriormente mencionados, a divulgação do conhecimento, tanto na forma oral quanto escrita, adquire grande relevância para aqueles que fazem Ciência e para as instituições que os abrigam. Sendo, portanto, a capacidade de expressão em linguagem científica uma habilidade valiosa entre aqueles que se dedicam à produção do conhecimento científico (caminho que costuma ser seguido principalmente por 
alunos de bacharelado em Química), é preocupante o fato de que menções sobre a flagrante dificuldade encontrada pelos estudantes de graduação em Química na comunicação de seus conhecimentos sejam constantemente encontradas em revistas especializadas de Educação em Ciências.

Como o campo da Química é potencialmente quantitativo, os currículos dos cursos de Química no ensino superior, de uma forma geral, enfatizam o desenvolvimento de habilidades quantitativas, em prejuízo do desenvolvimento de habilidades qualitativas, como a escrita e a expressão oral (QUEIROZ, 2001). No entanto, na tentativa de eliminar, ou pelo menos amenizar essa dificuldade, várias universidades têm oferecido disciplinas que lançam mão de estratégias de ensino, usadas tanto em sala de aula como no laboratório.

Em uma revisão feita no periódico Journal of Chemical Education, no período de 1995 a junho de 2006, encontramos 31 artigos que relatam experiências relacionadas ao desenvolvimento da expressão oral e escrita em cursos de Química, os quais são listados no Apêndice A desta dissertação. De uma maneira geral estes se subdividem em dois tipos: a) Disciplinas voltadas especificamente para o desenvolvimento de tais habilidades, as quais representaram 39\% dos artigos pesquisados; b) Disciplinas direcionadas para o ensino de Química, mas que trazem em seu bojo a preocupação com o desenvolvimento de tais habilidades, compreenderam $61 \%$ dos artigos.

Nas disciplinas específicas o tempo disponível para a realização de atividades que visam o aprimoramento das habilidades acima descritas é sempre maior, quando comparado às disciplinas direcionadas para o ensino de Química. Em contrapartida, estas últimas permitem uma contextualização das atividades, que é entendida como extremamente estimulante para os estudantes e que tem rendido bons frutos.

As disciplinas específicos adotam, de um modo geral, estratégias para o desenvolvimento de habilidades de comunicação científica que são aplicadas em sala de aula 
como aulas expositivas sobre características da redação científica e das apresentações orais e de painéis, realização de tarefas pelos alunos que abarcam atividades escritas e orais, dentre outras. No trabalho relatado por Ordman (1996), por exemplo, foi aplicada uma disciplina chamada Practical Skill for Undergraduate Science Major cujos tópicos abordados envolviam preparo de resumos, de apresentações orais, de utilização dos recursos disponíveis no Chemical Abstracts, pesquisa bibliográfica em bases de dados, utilização de processadores de texto, visita a indústrias e planejamento da carreira. Observa-se, portanto, duas preocupações distintas: a comunicação científica e o preparo profissional.

O objetivo de preparar o aluno para a vida profissional também está presente na disciplina Research Skills \& Ethics, na qual são apresentados aos alunos temas como ética em ciência, segurança no laboratório, pesquisa bibliográfica, técnicas de apresentações orais e redação de artigos científicos. Os alunos também aprendem a preparar cartões sociais, currículos profissionais, cartas a empresas, além de assistirem a aulas de informática, planejamento de experimentos, estatística e análise de dados (MABROUK, 2001). A utilização de recursos da web em atividades direcionadas ao desenvolvimento de tais habilidades também é explorada por McGowan e Sendall (1997), bem como atividades que habilitem os alunos na pesquisa de literatura em Química em diversas bases de dados (COOKE, 1994). Sob o aspecto da comunicação científica, a disciplina descrita por Paulson (2001), Chem 360: Writing for Chemistry, bastante semelhante ao citado por Mabrouk (2001), apresenta aulas sobre pesquisa bibliográfica, redação científica e técnicas de apresentação oral e de painéis. Nas atividades realizadas em Chem 460: Senior Seminar os alunos recebem temas comuns e produzem individualmente resumos, artigos curtos e artigos completos e ainda realizam uma apresentação oral sobre os temas. No entanto, todos os textos são elaborados a partir de discussões em grupo, objetivando-se, assim, uma troca de informações e aprendizado coletivo (BOWYER; KAYDOS, 1997). 
A produção de textos científicos, seguida de uma apresentação oral sobre o mesmo tema também é bastante explorado em outras disciplinas (ROSSI, 1997). O processo de avaliação também é utilizado como recurso para promover o envolvimento dos alunos com seu aprendizado e o dos colegas. Um exemplo é o trabalho descrito por Walner e LatosiSawin, (1999), no qual o professor solicita que os alunos avaliem seus colegas e fornece, para isso, os critérios que eles devem utilizar no processo. Esta estratégia leva a uma maior atenção dos alunos com relação às atividades e lhes permite aprender com os erros e acertos dos colegas. Atividades nas quais os alunos devem desenvolver texto no formato exigido por um periódico específico foram observadas na disciplina relatada por Bressette e Breton (2001), na qual os alunos têm um semestre para escrever um artigo que será publicado no The Berry College Journal of Chemistry, um jornal produzido na própria universidade. Neste caso, durante o semestre eles recebem instruções sobre pesquisa bibliográfica e redação de artigos, além de terem seus textos periodicamente revisados pelos professores. Na disciplina Chem 300: The Literature of Chemistry, observa-se uma proposta semelhante: os alunos escrevem, em grupo, um artigo que é revisado pelo professor para que seja publicado no Journal of Household Chemistry, também produzido na própria universidade (SCHMIDT, 1997).

No que diz respeito às disciplinas regulares da grade curricular de Química, nas quais os professores utilizam várias estratégias, seja em sala de aula ou no laboratório, para o desenvolvimento de habilidades de comunicação científica, as atividades de leitura e análise por escrito de artigos científicos (WILLIAMS, 1997) ou mesmo livros textos são amplamente exploradas (COMEFORD, 1997), bem como estratégias de aprendizado cooperativo (DOUGHERTY et al, 1995; DOUGHERTY, 1997). A avaliação mútua é a estratégia relatada por Shirbley et al. (2001), na qual os alunos, além de redigirem textos científicos, têm seus escritos avaliados por outros dois colegas. Assim, cada aluno faz uma análise crítica dos trabalhos dos colegas e, ao mesmo tempo, tem seu trabalho analisado para uma posterior 
revisão. A avaliação por parte dos próprios alunos é também observada na disciplina descrita por Mill et al. (2000), que exige o preparo e apresentação de painéis sobre algumas das atividades práticas de laboratório ou outro tema ligado ao curso. Em seguida, cada estudante avalia o painel apresentado pelo colega através de uma ficha fornecida pelo professor. Cabe ressaltar que a utilização de painéis é um freqüente recurso para o desenvolvimento de habilidades de expressão oral e escrita e para reforçar o conteúdo de Química em disciplinas de graduação (DUNSTAN; BASSINGER, 1997; SISAK, 1997).

Na maioria das disciplinas não-específicas, um fato observado foi a posição ativa dos alunos no processo de ensino-aprendizagem. Embora estas disciplinas ofereçam aulas expositivas, alguns dos mecanismos utilizados tornam os próprios alunos mais responsáveis pelo desenvolvimento de habilidades de expressão oral e escrita. Como exemplo, podemos citar o trabalho relatado por Nilsson (2001), no qual os alunos ministram aulas de revisão para os colegas. O conteúdo da aula é dividido previamente pelo professor entre os alunos que, em pares, ministram a aula supervisionada e complementada pelo professor. Desta forma, os alunos reforçam o conteúdo, tiram suas dúvidas para a prova, sentem-se mais comprometidos com a atividade proposta e ainda desenvolvem habilidades de expressão oral. Em outros casos os alunos realizam atividades como escrever artigos sobre um método experimental e redigir textos argumentando contra ou a favor da compra de um determinado modelo de instrumento para o método escolhido, além de pesquisarem modelos, fornecedores, cotação, etc. (HUNTER, 1998). Assim, além de desenvolver habilidades de escrita e capacidade de argumentação, a atividade ambienta os alunos em questões práticas de laboratório. A redação de cartas aos colegas sobre seu dia-a-dia e atividades realizadas em sala de aula também é solicitada visando estimular a escrita de forma simples entre os alunos de Química (KIRMS, 2004). No trabalho relatado por Kovac e Sheerwood (1999), os alunos escrevem sobre microtemas relacionados ao conteúdo da aula, além de realizarem práticas de leitura de livros 
texto. A escrita, portanto, parece ser é o foco principal destas disciplinas e de outras como os relatados por Hermann (1994) e Wilson (1994), nos quais ambos, em disciplinas de Química Orgância, utilizaram diversas atividades que objetivaram desenvolver a habilidade de escrita e promover um aprendizado mais consistente.

O laboratório, conforme mencionado anteriormente, também é um importante locus para a prática da comunicação científica em cursos de graduação em Química. Tilstra (2001) relata a experiência realizada em uma disciplina de Química Geral, na qual algumas práticas de laboratório foram selecionadas para que os alunos preparassem, a partir dos dados coletados, relatórios no formato exigido para publicação de artigos no Journal of The American Chemical Society. Para o cumprimento da atividade, os alunos recebem informações sobre pesquisa bibliográfica e técnicas de redação científica e produzem quatro relatórios, cuja profundidade do conteúdo e organização crescem seqüencialmente, fazendo com que os alunos corrijam seus erros e melhorem a cada nova atividade. Em uma outra disciplina, Theory and Practice of Quantitative Chemistry, as atividades de laboratório também são direcionadas às práticas de redação e expressão oral. Para tanto, os alunos desenvolvem, em grupo, pequenos projetos de pesquisa, fazem pesquisa bibliográfica, lêem e discutem artigos relacionados ao tema, escrevem relatórios dos experimentos realizados e, ao término da disciplina, fazem uma apresentação oral do trabalho desenvolvido. Todas as orientações sobre o formato da escrita e fala científica são fornecidas pelo professor no decorrer da disciplina em aulas expositivas (WHELAN; ZARE, 2003).

Ademais, desenvolver no aluno a capacidade de realizar pesquisas em bases de dados na área de Química também é objetivo presente em disciplinas como a descrita por Rossenstein (2005), onde os alunos realizam pesquisa no Chemical Abstract através do software Scifinder Scholar para resolução de exercícios da disciplina de Química Orgânica. Em outra disciplina de Química Orgânica é possível perceber o enfoque dados às atividades 
de pesquisa bibliográfica, leitura e análise crítica da literatura primária (ALMEIDA; LIOTTA, 2005).

No Brasil, de acordo com o levantamento bibliográfico realizado, existem duas disciplinas de graduação que se destinam especialmente ao desenvolvimento de habilidades de comunicação científica, ambas ministradas para alunos do primeiro ano do Curso de Bacharelado em Química do Instituto de Química de São Carlos. A primeira delas, denominada Comunicação e Expressão em Linguagem Científica I, tem como objetivo discutir as diversas formas como a Ciência é divulgada e apresentar aos estudantes os tipos de artigos científicos e suas características peculiares Esta disciplina visa ainda apresentar diversas fontes de informação em Ciência e fomentar discussões sobre a importância da comunicação para o profissional da área de Química, com ênfase no papel da linguagem escrita na pesquisa científica. A segunda, Comunicação e Expressão em Linguagem Científica II, objetiva familiarizar os estudantes com a leitura e interpretação de artigos científicos e discutir aspectos inerentes à produção de painéis e de apresentações orais (OLIVEIRA; QUEIROZ, 2005).

As estratégias utilizadas na disciplina Comunicação e Expressão em Linguagem Científica I incluem aulas expositivas, nas quais são apresentados aos alunos os principais tipos de documentos produzidos no meio científico. Também são apresentados aspectos sobre o público a que se destinam e a estrutura do texto dos diversos tipos de artigos científicos. Para atingir tal objetivo, os alunos, em aulas práticas na biblioteca, localizam artigos das revistas Eclética Química e/ou Química Nova e os classificam de acordo com os critérios previamente estudados. Além disso, os estudantes são apresentados às principais bases de dados existentes na biblioteca do Instituto de Química de São Carlos, e recebem informações sobre a utilização das seguintes bases: Metadex, Portal Capes, Dedalus (Base bibliográfica de trabalhos existentes na USP), Scielo, Web of Science. Em aulas práticas posteriores os alunos 
localizam informações científicas solicitadas pelo docente fazendo uso destas bases. Os alunos também aprendem a consultar o Currículo Lattes de pesquisadores e a realizar pesquisa bibliográfica na versão em papel e on-line do Chemical Abstracts, principal coletânea de index e resumos de trabalhos publicados na área de química. Todas as atividades são realizadas em grupo (OLIVEIRA; QUEIROZ, 2005).

As estratégias utilizadas na disciplina Comunicação e Expressão em Linguagem Científica II incluem: aulas expositivas, aulas práticas sobre a utilização do programa Power Point, a organização de um mini-simpósio, no qual os estudantes apresentam resultados expostos em um artigo científico no formato oral e de painel, e a resolução de um caso investigativo. Assim, através de atividades dirigidas, realizadas em sala de aula e na biblioteca, os alunos estudam e discutem o conteúdo de um determinado artigo, extraído das revistas Eclética Química e Química Nova, realizando o reconhecimento de suas principais seções e de outros componentes como: título, autores, instituições de origem dos autores etc. Os alunos realizam ainda apresentações sobre o conteúdo do artigo no formato oral e de painel em um mini-simpósio (SANTOS, 2006). A última estratégia colocada em prática nesta disciplina visa fortalecer nos alunos a habilidade de comunicação oral e a capacidade de busca em fontes de informação de Ciência através da resolução em grupos de um caso investigativo. As resoluções dos casos propostos são apresentadas oralmente em um segundo simpósio (SÁ; QUEIROZ, 2005; SÁ, 2006).

Todas as disciplinas mencionadas, via de regra, foram aplicadas em turmas reduzidas e a metodologia de avaliação sobre a eficácia das mesmas foi usualmente feita de forma qualitativa, levando em conta os relatos e as percepções dos alunos sobre as atividades realizadas. Uma das raras exceções no formato da avaliação das disciplinas foi verificada na disciplina Scientific Communication, na qual se aplicou um teste quantitativo, o PRPSA (Personal Report of Speaking Public Anxiety), para avaliar os níveis de ansiedade dos alunos 
em relação a expressão oral em público, antes ao término da disciplina (MEYER, 2003). Cabe ainda ressaltar que, a partir do levantamento bibliográfico realizado, percebemos na maioria das disciplinas escassez de material didático específico para ser utilizado em sala de aula. Em alguns casos foram apresentadas algumas aulas teóricas sobre formas de comunicação escrita e oral, artigos extraídos de revistas foram utilizados para realização das atividades de ensino e fichas contendo informações do tipo "dicas de como fazer" foram distribuídas entre os alunos. 
A importância do desenvolvimento das habilidades de comunicação em linguagem científica dos alunos das áreas de Ciências Naturais conduziu alguns autores à publicação de livros relacionados à temática. Entre eles estão A Guide to Write in Science (GILPIN; PATCHET-GOLUBEV, 2000), no qual as características inerentes aos diferentes tipos de textos científicos são descritas e Writing Papers in Biological Sciences (McMILLAN, 1997), que trata detalhadamente de aspectos relacionados à escrita científica e se destina a estudantes mais experientes, como mestrandos e doutorandos. Livros produzidos especificamente para a área de Química são também encontrados na literatura, como o The ACS Style Guide: A Manual for Authors and Editors (DODD, 1997), no entanto, são também destinados a autores e a editores mais experientes.

De acordo com a pesquisa realizada na literatura, não existem relatos sobre a publicação de materiais didáticos sobre comunicação científica, específicos para a área de Química, no Brasil. Considerando a ausência, no nosso país, de materiais didáticos dos tipos acima citados e a importância que é creditada ao desenvolvimento das habilidades em foco entre os alunos de graduação em Química, tem-se como objetivo principal a elaboração e validação de um material didático dessa natureza a eles destinado. Acredita-se que o material 
poderá vir a auxiliar a realização de ações que conduzam ao desenvolvimento das habilidades mencionadas.

A elaboração do referido material se deu com base nos fundamentos da pesquisa participativa (LE BOTERF, 1999). Foram sujeitos da pesquisa alunos de graduação e pósgraduação em Química e um docente da área. O percurso metodológico seguido permitiu, além da elaboração do próprio material, o conhecimento da visão dos sujeitos da pesquisa sobre a comunicação científica. Nesse contexto, objetivou-se também apresentar uma análise das discussões em grupo nas quais professores e alunos de Química expõem suas concepções e experiências sobre diversos temas relacionados à comunicação científica, correlacionandoas com experiências similares relatadas na literatura.

A participação dos sujeitos, através da apresentação de idéias e críticas, foi fundamental no desenvolvimento do material, de modo a torná-lo mais próximo das necessidades dos alunos e de fácil compreensão para os mesmos. A estrutura e organização do conteúdo foram planejadas de acordo com os dados obtidos das discussões em grupo e considerando ainda informações que foram adquiridas em livros e artigos nacionais e internacionais. Após concluído, o material foi validado através de questionário de avaliação aplicado a alunos de graduação e pós-graduação em Química e a docentes da área. 


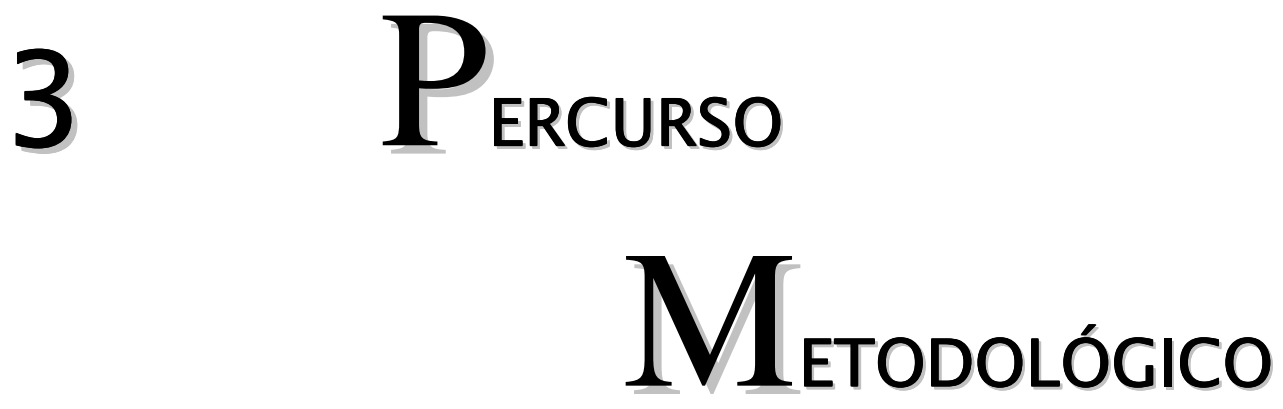

\subsection{REFERENCIAL TEÓRICO ADOTADO PARA O DELINEAMENTO DO PERCURSO METODOLÓGICO: PESQUISA PARTICIPATIVA}

A pesquisa participativa é definida resumidamente como uma pesquisa da ação voltada para as necessidades básicas do indivíduo. É a metodologia que procura incentivar o desenvolvimento autônomo dos sujeitos envolvidos direta ou indiretamente na construção do conhecimento. Assim, reconhece-se que a Ciência por ser constituída por regras, métodos e técnicas elaboradas na racionalidade humana está sujeita às influências provocadas pelos interesses, crenças e interpretações humanas e, portanto, não pode existir verdade absoluta na construção do conhecimento, sobretudo se construída isoladamente pelo cientista (BORDA, 1999).

Portanto, para a pesquisa participativa, o cientista deve recriar, de dentro para fora, formas concretas possibilitando às pessoas, aos grupos e às classes de participarem do direito de pensarem, produzirem e dirigirem os usos do seu saber e a respeito de si próprios. Desta 
forma, os grupos tornam-se responsáveis por si mesmos, assumindo seus problemas e buscando solução para os mesmos (BRANDÃO, 1999). Portanto, muda o papel do sujeito da pesquisa: ele não é só objeto estudado. Muda também o papel do pesquisador: ele não é mais o único dono da verdade, manipulando os sujeitos e ditando os objetivos. Muda, além disso, o papel da Ciência: não só o progresso do conhecimento muda, mas também a elaboração de possibilidade de ação que oriente a ação comum (VALLE, 1988).

A pesquisa participativa apresenta algumas modalidades ou estilos alternativos de trabalhos. Apesar das várias propostas, todas têm em comum a produção e apropriação coletiva do saber através da participação conjunta de pesquisadores e interessados (SILVA, 1991). A investigação participativa é um método que envolve seus supostos beneficiários num processo de investigação, educação-aprendizagem e ação.

A área de Ciências Sociais foi o berço da pesquisa participativa, embora atualmente possa ser utilizada como metodologia de estudo em diversas áreas do conhecimento. Na área da Saúde, esta metodologia tem apresentado crescimento significativo. Podemos citar como exemplo o trabalho descrito por Mello et al (1998), no qual a pesquisa participante, articulada à Educação em Saúde, foi realizada com a finalidade de diagnosticar condições de saneamento de uma comunidade, bem como promover ações de saúde e educação popular.

Como a pesquisa participante combina técnicas de pesquisa, processos de ensinoaprendizagem e programas de ação educativa, foi selecionada como estratégia na elaboração de um hipertexto digital juntamente com alunos, professores e outros agentes educacionais da comunidade de Quissamã, Rio de Janeiro. A tais sujeitos foi dada a oportunidade de analisar sua própria realidade e desenvolver ações que resultem em benefício social. Nesse estudo, o autor coloca a pesquisa participante "como instrumento metodológico adequado para permitir que a comunidade possa atuar, ao mesmo tempo, como usuário e produtor de informações sobre identidade cultural do município" (SANTO; FREIRE, 2004, p.160). 
No Brasil a pesquisa participativa ocupa um espaço também crescente na área da Pesquisa Educacional, inclusive com apoio institucional. Nesta metodologia, o problema de pesquisa consiste em alcançar determinados objetivos, conceber organizações, práticas educacionais e suportes materiais com características e critérios aceitos pelos grupos interessados (THIOLLENT, 2003). Araújo (2001), em trabalho publicado na revista Educação e Pesquisa, relata um estudo baseado em metodologia de pesquisa participante cujo objetivo foi compreender como as vivências escolares de jovens cujo cotidiano é marcado pela violência reorientam atitudes dos alunos entre si, e desses em relação aos professores e outros agentes escolares. Podemos citar também outros casos de aplicação da pesquisa participativa na área de Educação como, por exemplo, o trabalho desenvolvido por Fonseca (2002), no qual esta metodologia foi utilizada para o desenvolvimento de um material didático de Educação em Saúde - Cartilha Educativa de Atenção ao Bebê Prematuro - através da ação conjunta de pesquisadores, enfermeiras e mães de bebês prematuros.

Assim, delinear o percurso metodológico nesse trabalho, tendo por base a pesquisa participativa, mostrou-se conveniente uma vez que o objetivo da pesquisa foi a elaboração de um material didático-instrucional sobre comunicação em linguagem científica e acredita-se que, para atingir tal objetivo, seria importante a participação dos interessados durante todo o processo a ser adotado, a fim de que fosse possível conhecer suas realidades e obter suas impressões sobre o material.

Desta forma, o presente trabalho foi realizado através da participação de seis alunos (em diferentes graus de formação) e de um professor no processo de elaboração de um material didático, o qual poderá beneficiá-los direta ou indiretamente. O aluno poderá ser beneficiado diretamente com o material voltado especificamente para suas necessidades de desenvolvimento de habilidades de comunicação. Poderá ser beneficiado o professor, pois terá alunos mais bem preparados para a realização de várias atividades que necessitam da 
expressão oral ou escrita em linguagem científica, melhorando desta forma a participação dos alunos nas disciplinas. Por esse motivo, educandos e educadores, participaram ativamente do processo, desde a identificação dos problemas que os alunos enfrentam na expressão de seus conhecimentos, a definição dos principais tópicos a serem abordados no material, até sua forma de organização e apresentação para os alunos.

\subsection{METODOLOGIA DA PESQUISA E FORMA DE COLETA DE DADOS}

No que se refere ao processo metodológico, neste trabalho foi seguida seguinte sequiência metodológica adaptada da proposta definida por Le Boterf (1999), dividida em quatro etapas:

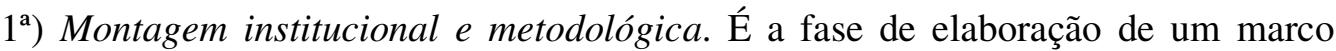
teórico geral para um trabalho futuro, ou seja, elaboram-se as estratégias adotadas, definem-se os sujeitos da pesquisa, a área de atuação;

$2^{\mathrm{a}}$ ) Estudo preliminar e provisório. Busca-se a percepção concreta dos indivíduos relacionados à pesquisa. Pode-se realizar nessa fase análises de documentos, entrevistas semi-estruturadas para obtenção de conhecimento prévio;

$3^{\mathrm{a}}$ ) Análise crítica dos problemas considerados prioritários. Esta fase é realizada através de discussões livres dos sujeitos participantes da pesquisa;

$\left.4^{\mathrm{a}}\right)$ Programação e execução de um plano de ação (incluindo ações educativas). Nesta fase busca-se definir a melhor estratégia para atingir os objetivos da pesquisa de maneira que responda aos questionamentos levantados nas discussões em grupo. 
É importante ressaltar que as fases de uma pesquisa participativa não se constituem em uma seqüência linear, podendo uma pesquisa se concentrar mais em uma fase ou em outra, conforme o contexto e objetivos dos participantes (SILVA, 1991).

\subsubsection{Montagem Institucional e Metodológica}

A primeira fase do presente trabalho, montagem institucional e metodológica, consistiu na seleção dos sujeitos envolvidos na pesquisa. Foram convidados os seguintes participantes: dois alunos do segundo ano do curso de Química $\left(\mathrm{AG}_{1}\right.$ e $\left.\mathrm{AG}_{2}\right)$; dois alunos de iniciação científica em fase de conclusão do curso de Química $\left(\mathrm{AI}_{1}\right.$ e $\left.\mathrm{AI}_{2}\right)$; dois estudantes de pós-graduação, sendo um mestrando e um de doutorando $\left(\mathrm{AP}_{1}\right.$ e $\left.\mathrm{AP}_{2}\right)$; e um professor do ensino superior de Química (PR), o qual ministra disciplinas de graduação e pós-graduação e atua como pesquisador na área de Química.

Cada um dos sujeitos de pesquisa tem sua particularidade e importância no andamento do processo. Como o material didático a ser produzido seria direcionado aos estudantes de graduação, estes estiveram presentes em maior número nesta pesquisa. Assim, foram selecionados alunos do segundo ano do Curso de Bacharelado em Química pelo fato de, supostamente, ainda não conhecerem todo o processo de produção de documentos científicos e, desta forma, poderiam informar sobre as primeiras dificuldades encontradas com a expressão em linguagem científica, o que esperavam de um material didático sobre este tema, bem como poderiam expor suas concepções iniciais sobre a importância da comunicação científica. Além disso, pelo fato de tais sujeitos possivelmente já terem produzido seus primeiros trabalhos nos quais foram necessárias as habilidades de comunicação oral ou escrita, como os relatórios de laboratório ou seminários, poderiam também apresentar idéias a respeito dos temas abordados durante a elaboração do material. 
Foram selecionados também alunos de iniciação científica em fase de conclusão do Curso de Licenciatura em Química, os quais necessitaram ao longo do curso desenvolver habilidades de comunicação científica (pesquisa bibliográfica, redação de relatórios, resumos, apresentações orais) para elaboração de seus trabalhos acadêmicos e, portanto, já tinham possivelmente algum conhecimento sobre o assunto em pauta. Por esse motivo, tais sujeitos de pesquisa poderiam analisar criticamente, a partir de um certo conhecimento prático prévio, além de assuntos relacionados à comunicação científica, o material didático como um todo.

Os estudantes de pós-graduação, por já terem passado por várias etapas que os levaram a desenvolver diversos trabalhos em linguagem científica, bem como saberem reconhecer as dificuldades encontradas para desenvolvê-los, foram selecionados no sentido de vir a fornecer informações úteis para a elaboração do material didático, além de expor suas visões críticas baseadas em suas experiências pessoais relacionadas à comunicação científica.

O docente, no contexto de sua experiência em sala de aula ou no laboratório, poderia relatar as dificuldades enfrentadas por seus alunos para a realização de trabalhos nos quais é requerida a expressão oral e escrita em linguagem científica. Ademais, poderia descrever importantes habilidades de comunicação científica a serem desenvolvidas na formação do graduando em Química. Desta forma, forneceria importantes informações para a elaboração do material didático. Cabe lembrar também que, tendo em vista a sua experiência como pesquisador, poderia manifestar uma visão mais crítica sobre como a comunicação tem se apresentado nos dias atuais.

\subsubsection{Estudo Preliminar Provisório}

A segunda fase da pesquisa participativa consistiu de um estudo preliminar provisório da população investigada ou, particularmente em nossa pesquisa, da população beneficiária da pesquisa proposta, buscando-se compreender como os indivíduos interpretam 
os problemas relacionados à comunicação científica. Desta forma, pretendeu-se compreender quais as impressões que os alunos de graduação em Química, particularmente os iniciantes, têm sobre a comunicação e expressão em linguagem científica.

Convém ressaltar que nessa fase, a maneira utilizada para inserir o pesquisador no meio sem interferir na dinâmica normal dos alunos investigados foi através do Programa de Aperfeiçoamento de Ensino (PAE) da Universidade de São Paulo (USP, 2006). Ao participar como estagiário na disciplina Comunicação e Expressão em Linguagem Científica I, o pesquisador pode interagir livremente com os alunos, observar suas dificuldades e recolher suas impressões sobre a comunicação científica. Tais informações foram utilizadas como ponto de partida para as discussões em grupo, realizadas na fase subseqüente da pesquisa.

\subsubsection{Análise Crítica dos Problemas Considerados Prioritários}

Após a consolidação do grupo de pesquisa e tendo-se executado o estudo preliminar provisório, foram realizadas reuniões periódicas, segundo cronograma de atividade previamente elaborado, nas quais foi realizada a terceira fase da pesquisa: análise crítica dos problemas considerados prioritários. Assim, foram discutidos os problemas dos alunos, bem como dos professores, no contexto da comunicação científica, estabelecidos os objetivos do material didático, selecionados os tópicos considerados primordiais para sua execução, os conteúdos a serem abordados em cada tópico, sua forma de organização e apresentação, bem como adequação ao grupo-alvo. Enfim, foram realizadas discussões sobre todo o processo de desenvolvimento do material didático. A Tabela 1 resume as reuniões realizadas nessa fase e as atividades desenvolvidas.

Foi realizada uma reunião inicial para apresentação da proposta de estudo ao grupo. Foi entregue na ocasião o Termo de Consentimento Informado, apresentado no Apêndice B 
deste trabalho, no qual foram esclarecidos a cada participante os objetivos do estudo e as normas éticas que regiam a pesquisa. Estabeleceu-se ainda na ocasião a programação das reuniões a serem realizadas naquele semestre.

Tabela 1 - Resumo das reuniões de grupo, ocorridas durante a fase de análise crítica dos problemas considerados prioritários, para elaboração participativa de um material didático sobre comunicação científica.

\begin{tabular}{|c|c|c|}
\hline & PARTICIPANTES & ATIVIDADES REALIZADAS \\
\hline $1^{\mathrm{a}}$ & $\mathrm{PR}, \mathrm{AG}_{1}, \mathrm{AG}_{2}$ & Apresentação do problema de estudo e da proposta da \\
\hline $19 / 04 / 05$ & $\mathrm{AI}_{1}, \mathrm{AI}_{2}$ e $\mathrm{AP}_{1}$ & pesquisa (objetivos gerais e dinâmica de trabalho). \\
\hline $2^{\mathrm{a}}$ & $\mathrm{AG}_{1}, \mathrm{AG}_{2}$ & Discussão sobre as dificuldades relacionadas à \\
\hline 03/05/05 & $\mathrm{AI}_{1}$ e $\mathrm{AI}_{2}$ & comunicação científica. \\
\hline & & Discussões sobre a importância do material didático. \\
\hline $\begin{array}{c}2^{\mathrm{a}} \\
03 / 05 / 05\end{array}$ & $\mathrm{PR}, \mathrm{AP}_{1}$ & $\begin{array}{l}\text { Discussão sobre as dificuldades relacionadas à } \\
\text { comunicação científica. }\end{array}$ \\
\hline & & Discussões sobre a importância do material didático \\
\hline $3^{\mathrm{a}}$ & $\mathrm{PR}, \mathrm{AG}_{1}, \mathrm{AG}_{2}$ & Discussões sobre os tópicos considerados prioritários a \\
\hline 07/06/05 & $\begin{array}{l}\mathrm{AI}_{1}, \mathrm{AI}_{2}, \mathrm{AP}_{1} \\
\mathrm{e} \mathrm{AP}_{2}\end{array}$ & $\begin{array}{l}\text { serem abordados (temas geradores dos debates), bem } \\
\text { como sua seqüência e conteúdo. }\end{array}$ \\
\hline $\begin{array}{c}4^{\mathrm{a}} \\
21 / 06 / 05\end{array}$ & $\mathrm{PR}, \mathrm{AP}_{1}$ e $\mathrm{AP}_{2}$ & $\begin{array}{l}\text { Discussão sobre a forma de apresentação do material } \\
\text { (veículo de divulgação a ser adotado). }\end{array}$ \\
\hline & & $\begin{array}{l}\text { Apresentação da lista de tópicos a serem abordados no } \\
\text { material sugeridos pelos participantes. }\end{array}$ \\
\hline
\end{tabular}

$\mathrm{Na}$ segunda reunião foram iniciados os debates sobre questões relacionadas à comunicação científica, mais especificamente sobre as dificuldades enfrentadas e/ou 
observadas pelos alunos e pelo professor para o desenvolvimento de trabalhos orais e escritos em linguagem científica. Foram utilizadas na ocasião questões direcionadoras dos debates, descritas logo a seguir.

- Que tipo de dificuldade os alunos apresentam mais freqüentemente em relação à comunicação e expressão em linguagem científica?

- Qual a importância da comunicação científica para o graduando de Química?

- Você acha que um material didático sobre comunicação científica pode contribuir para aprimorar habilidades de comunicação científica?

Tais questões, no entanto, serviram apenas para início das discussões sobre diversos temas relacionados à comunicação científica, uma vez que, dada às características desta pesquisa, os sujeitos poderiam expressar livremente suas idéias e críticas sobre o assunto em pauta. Convém ressaltar que particularmente nesta etapa foram formados pequenos e grandes grupos de discussão. Ou seja, esses debates (segunda reunião) ocorreram em grupos separados: no primeiro grupo estiveram presentes os alunos de graduação, e no segundo grupo, os alunos de pós-graduação e o professor. O objetivo destas reuniões em grupos menores foi deixar os participantes mais livres de influências externas para expressarem suas opiniões e idéias. Assim, os alunos de graduação, por exemplo, puderam se sentir mais à vontade sem a presença do professor e de outros alunos "mais conhecedores" do tema. Os outros participantes, da mesma forma, puderam expressar livremente suas idéias e contribuições à pesquisa.

$\mathrm{Na}$ terceira reunião desta fase iniciaram-se as discussões sobre os tópicos considerados importantes para elaboração do material didático. Para o direcionamento dos debates, foi entregue aos participantes uma lista de tópicos a serem discutidos, a qual está 
apresentada na íntegra no Apêndice $\mathrm{C}$ deste trabalho. De um modo geral, essa lista focalizou os seguintes assuntos:

- A importância da comunicação científica na vida profissional do químico;

- A circulação das informações no meio científico;

- Ética em comunicação científica;

- Tipos de documentos científicos (projetos, relatórios, artigos, dissertações etc);

- Apresentações orais;

- Principais componentes de trabalho científico (título, autores, introdução etc);

- A linguagem científica em Química.

Na última reunião dessa fase, apresentou-se aos sujeitos uma nova lista de tópicos a serem abordados no material, revisada de acordo com suas sugestões e críticas. Além disso, levantou-se também na ocasião questionamentos sobre o veículo de divulgação a ser adotado para apresentação do material (texto impresso, CD-ROM, página na Internet etc.). Todos os encontros dessa fase foram gravados em áudio e, posteriormente, transcritos para análise das falas dos sujeitos de pesquisa.

\subsubsection{Programação e Execução de um Plano de Ação}

A última fase da pesquisa foi a realização da programação e execução de um plano de ação, a qual incluiu a produção e a validação do material didático. Para a elaboração do material, uma extensa revisão bibliográfica foi realizada em livros e periódicos nacionais e internacionais que tratam do tema: linguagem científica. Foram estudadas as formas mais utilizadas de comunicação, as quais foram discutidas por todos os participantes da pesquisa. $\mathrm{O}$ desenvolvimento de cada tópico do material didático, seus conteúdos, seqüência dos tópicos, 
subdivisões, linguagem utilizada etc., foi conduzido a partir de dados obtidos na literatura e, principalmente, da participação do grupo de pesquisa com suas idéias, sugestões e críticas fornecidas no decorrer das reuniões de grupo. A Tabela 2 resume as atividades realizadas nessa etapa.

Tabela 2 - Resumo das reuniões de grupo, ocorridas durante a fase de programação $e$ execução de um plano de ação, para elaboração participativa de um material didático sobre comunicação científica.

\section{PARTICIPANTES ATIVIDADES REALIZADAS}

\begin{tabular}{cll}
\hline $1^{\mathrm{a}}$ & $\mathrm{PR}, \mathrm{AG}_{1}$ e $\mathrm{AP}_{1}$ & Discussão sobre o tópico do material "Componentes \\
$11 / 10 / 05$ & Principais dos Textos Científicos"
\end{tabular}

$2^{\mathrm{a}} \quad \mathrm{AG}_{1}, \mathrm{AG}_{2}$ e $\mathrm{AP}_{1} \quad$ Discussão sobre o tópico do material "Algumas Formas de Documentos Científicos"

$3^{\mathrm{a}} \quad \mathrm{AG}_{1}, \mathrm{AG}_{2}$ e $\mathrm{AP}_{1}$

Discussão sobre os tópicos do material "Considerações 20/04/06 Sobre a Comunicação Científica", "Localizando e Utilizando a Literatura em Química" e "Linguagem Científica em Química”

$4^{\mathrm{a}} \quad \mathrm{PR}, \mathrm{AG}_{1}, \mathrm{AG}_{2}, \quad$ Discussão final sobre todo o material. $11 / 05 / 06 \quad \mathrm{AP}_{1}$ e $\mathrm{AP}_{2}$ Aplicação do questionário de avaliação do material.

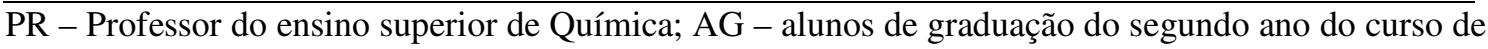
Química; AP - alunos de pós-graduação em Química.

Assim, pode-se observar que após a elaboração de cada parte do material, esta foi entregue para avaliação e discussão entre os sujeitos da pesquisa. Após cada reunião, os tópicos do material, analisados na ocasião, foram reorganizados de acordo com as sugestões e críticas do grupo, ou seja, o material foi desenvolvido de forma participativa.

$\mathrm{Na}$ primeira reunião foi analisado pelos participantes o tópico do material Componentes Principais dos Textos Científicos. Na ocasião foram discutidas as diferentes 
partes de um trabalho científico (Título, Autores, Afiliações, Resumos, Palavras-chave, Introdução, Materiais e Métodos etc.). Diante de todas essas informações, o material foi sendo reorganizado.

A segunda reunião contemplou a análise e discussão do tópico do material Algumas Formas de Documentos Científicos. Na ocasião os sujeitos analisaram as informações expostas sobre relatórios, artigos científicos, trabalhos apresentados em reuniões científicas, projetos de pesquisa, artigos científicos de divulgação, artigos relacionados à Educação em Ciência, livros didáticos, artigos de divulgação da Ciência.

Os tópicos Considerações Sobre a Comunicação Científica, Localizando e Utilizando a Literatura em Química e A Linguagem Científica em Química foram analisados e discutidos na terceira reunião. Convém ressaltar que devido ao término do semestre após a segunda reunião (23/11/2006), esses tópicos foram elaborados durante um período de tempo mais longo até a realização da terceira reunião. Por esse motivo, três tópicos foram analisados simultaneamente na terceira reunião. Desta forma, na ocasião os sujeitos de pesquisa analisaram inicialmente o tópico Considerações sobre a Comunicação Científica, onde foi apresentado um breve histórico da evolução da comunicação cientifica, bem como aspectos relacionados ao marketing e ética em divulgação científica. Posteriormente foi analisado o tópico Localizando e Utilizando a Literatura em Química, no qual foram descritas as principais fontes de pesquisa bibliográficas (primárias, secundárias e terciárias), bem como as principais bases de dados de localização bibliográfica em Ciência. Por último, os sujeitos analisaram nessa reunião o tópico A Linguagem Científica em Química, onde se apresentam as principais características da linguagem científicas, os tempos verbais utilizados nos textos científicos e os jargões científicos.

A quarta reunião desta fase consistiu em uma discussão geral sobre o material como um todo. Assim, além de rediscutirem alguns pontos já citados em outros encontros ou pontos 
que passaram despercebidos na ocasião, foram analisadas também questões referentes ao título do material, a organização do Sumário, a seção Apresentação etc., bem como aspectos de apresentação visual (fontes, espaçamento, realces e sublinhados).

Todos os encontros dessa fase também foram gravados em áudio e, posteriormente, transcritos para análise das falas dos sujeitos de pesquisa.

Após a realização das últimas correções de todo o material, de acordo com as críticas e sugestões do grupo, foi realizada, ainda nesta fase, a etapa de validação final do material. Assim, foram selecionados novos sujeitos relacionados à área de Química para análise do Material: dois alunos de pós-graduação, dois alunos de graduação matriculados na disciplina Comunicação e Expressão em Linguagem Científica I, dois alunos de iniciação científica em Química e dois professores de Química que ministram aulas no ensino superior. A estes sujeitos foi entregue o material final impresso e o questionário de avaliação apresentado no Apêndice D. 


\section{4 $\mathrm{R}_{\text {esultados }}$}



Conforme mencionamos anteriormente, neste trabalho foi elaborado e validado um material didático capaz de subsidiar a realização de ações que conduzam ao desenvolvimento das habilidades de comunicação em linguagem científica de alunos de graduação em Química. Uma vez que a elaboração do referido material se deu com base nos fundamentos da pesquisa participativa (LE BOTERF, 1999), o percurso metodológico seguido permitiu, além da elaboração do próprio material, o conhecimento da visão dos sujeitos da pesquisa sobre a temática "comunicação científica". Assim, neste capítulo discute-se inicialmente essas visões e, em seguida, a maneira como as discussões realizadas entre os sujeitos da pesquisa e as suas observações a respeito do material didático, se refletiram na construção do mesmo.

\subsection{A COMUNICAÇÃO CIENTÍFICA NA VISÃO DOS SUJEITOS DA PESQUISA}

$\mathrm{Na}$ segunda fase desta pesquisa, definida como análise crítica dos problemas considerados prioritários, foram realizadas reuniões de grupos, nas quais ocorreram 
discussões que conduziram à compreensão das diferentes visões dos sujeitos de pesquisa sobre aspectos relacionados à comunicação científica. Convém ressaltar que as informações a respeito de tais visões foram coletadas no contexto de debates sobre a produção de um material didático sobre comunicação científica. A apresentação e a discussão dessas visões são aqui colocadas tendo em vista de que podem ser utilizados como referenciais na elaboração de estratégias de ensino direcionadas ao desenvolvimento de habilidades de expressão em linguagem científica dos alunos de graduação em Química.

Diversos trabalhos reportados na literatura também buscam reconhecer as concepções de um determinado grupo sobre algum tema de interesse, através da análise de dados obtidos em entrevistas, transcrições de debates em grupo, questionários etc. Sant'Ana (2005) descreve estudo no qual foram analisadas as concepções de professores e diretores sobre questões relacionadas à inclusão escolar. Segundo a autora, a descrição das dificuldades existentes e as necessidades apontadas por esses profissionais são fontes de informações relevantes que devem ser levados em consideração quando da decisão de novas ações no contexto inclusão escolar. Buchweitz (2001) descreve um outro trabalho onde foram analisadas idéias de alunos concluintes de cursos de Licenciatura em Física e Ciências Biológicas, visando a identificação de aspectos relacionados à aprendizagem significativa. Investigações a partir das falas dos sujeitos de pesquisa também foram realizadas em outros trabalhos na literatura como, por exemplo, no estudo realizado por Chamlian (2003) em que foram analisadas entrevistas nas quais docentes da universidade descreviam suas experiências inovadoras. O objetivo desse trabalho foi procurar subsídios para a formação do professor universitário.

Nesse contexto, é apresentada a seguir uma análise das discussões em grupo nas quais professores e alunos de Química expõem suas concepções e experiências sobre diversos temas relacionados à comunicação científica. 
Dada às características da pesquisa participativa, na qual os sujeitos colaboraram voluntariamente, nem sempre foi possível ter presente nas reuniões todos os sujeitos de pesquisa. No entanto, alguns destes, embora não tenham participado dos debates orais, expuseram algumas de suas visões sobre o tema abordado através de textos escritos.

Após análise das transcrições das exposições orais dos sujeitos de pesquisa e de seus textos escritos foi possível realizar a identificação e categorização dos temas mais discutidos entre os alunos e o professor. Embora houvesse um roteiro com os tópicos direcionadores das discussões, em todas as reuniões os alunos e o professor expuseram livremente suas idéias e críticas relacionadas à comunicação científica. As principais categorias de discussão sobre a comunicação científica identificadas neste estudo foram: A Importância da Comunicação Científica; O Relatório de Laboratório; Apresentações Orais e Escrita Científica; Marketing e Ética em Comunicação Científica; e A Evolução da Ciência e sua Especialização.

A Tabela 3 apresenta o número de vezes em que os sujeitos de pesquisa relataram nas reuniões assuntos relacionados às categorias identificadas neste estudo.

Tabela 3 - Categorias de temas relacionados à comunicação científica e número de citações entre os sujeitos de pesquisa.

\section{Categorias}

$\begin{array}{lcc}\begin{array}{l}\text { Alunos de } \\ \text { graduação }\end{array} & \begin{array}{c}\text { Alunos de } \\ \text { pós-graduação }\end{array} & \text { Professor }\end{array}$

A Importância da Comunicação Científica

1

6

12

Marketing e Ética em Comunicação

Científica

A Evolução da Ciência e sua Especialização

O Relatório de Laboratório

Apresentações Orais e Escrita Científica

$-$
5 5
3

2

5

7

2 
Apresenta-se a seguir uma análise dessas categorias, correlacionando-as com trabalhos presentes na literatura que tratam do tema em questão.

\subsubsection{A Importância da Comunicação Científica}

Um dos primeiros assuntos abordados entre os sujeitos foi a importância da comunicação científica para os alunos de graduação em Química. Embora eles tenham discutido em outras reuniões aspectos relacionados à vida do pesquisador e sua relação com a publicação científica, como será comentado mais adiante, neste primeiro momento o foco do debate deste tema foi direcionado aos alunos. Todos os sujeitos de pesquisa ressaltaram a importância das habilidades de expressão em linguagem científica para graduandos de Química. No entanto suas concepções não foram uniformes, como pode ser observado em trechos de textos produzidos pelos participantes, onde versam sobre este tema.

Os alunos de graduação se posicionam sobre o tema, como ilustrado a seguir.

$\left(\mathbf{A G}_{2}\right)$ "De fundamental importância, não só para o graduando de química quanto para outros graduandos de cursos de ciências, a comunicação científica é a única forma de fazer com que as pessoas se comuniquem, a entender e explicar modelos e conceitos, tirar dúvidas, relatar idéias, fazer monografias, apresentações e até mesmo a responder questões de prova".

O professor, por outro lado, enfatiza a importância da comunicação científica a partir de uma visão de benefícios em longo prazo, sobretudo na vida profissional.

(PR) "Qualquer aluno de química deve dominar a linguagem científica sobre sua área, pois esta é sua moeda de sucesso. Só através da transmissão de seus conhecimentos, e suas idéias, é que o aluno, futuro profissional de química, poderá galgar sucesso".

E por fim, o aluno de pós-graduação, embora também direcione a comunicação científica para o futuro profissional do Químico, ressalta ainda sua importância tanto no universo acadêmico quanto em qualquer outra área de atuação profissional. 
$\left(\mathbf{A P}_{2}\right)$ “Ela é fundamental não só para os graduando que se direcionam para a vida acadêmica, mas também para os indivíduos que exercerão qualquer atividade diária onde seja necessária a expressão por meios de relatórios, projetos, memorandos etc. ou a comunicação direta com pessoas, palestras, consultorias etc.".

A importância e o papel da comunicação para o profissional da área de Química são abordados em alguns cursos de Química em disciplinas especialmente voltadas ao desenvolvimento de habilidades de expressão oral e escrita em linguagem científica. Conforme mencionado anteriormente, pode-se citar o exemplo da disciplina Comunicação e Expressão em Linguagem Científica I, onde são aplicadas estratégias que objetivam mostrar aos alunos a importância da comunicação nas várias áreas de atuação do Químico, enfatizando a importância da linguagem escrita no dia-a-dia de um pesquisador. Para atingir tal objetivo, uma atividade, pautada na leitura realizada pelos estudantes do capítulo Visita de um Antropólogo ao Laboratório, presente no livro A Vida de Laboratório, de Bruno Latour e Steve Woolgar (1997), fomenta as discussões sobre este tema (ZANON, ALMEIDA E QUEIROZ, 2005).

\subsubsection{O Relatório de Laboratório}

Um dos temas mais discutido entre os participantes foi o relatório de laboratório. Analisando-se as falas dos alunos de graduação, verificou-se que eles demoram um certo tempo até entrarem em contato verdadeiramente com a elaboração de relatório, pois, inicialmente, em sua maioria, apenas preenchem fichas sobre as aulas práticas. A seguir é apresentado o relato de um aluno de graduação sobre o fato.

$\left(\boldsymbol{A} \boldsymbol{G}_{I}\right)$ “É no começo, assim, para a gente preparar os relatórios eles (os professores) tentam facilitar um pouco. Eles dão um caderno e a gente só vai preenchendo. É na verdade é uma ficha. Então, quer dizer, em parte tirou do aluno ter que correr atrás digitar os relatório, preparar. A gente só preenche 
dados, não monta a estrutura, pois ela já está pronta. Parte que acaba só no segundo semestre, quando a gente começa a fazer".

Por outro lado, os alunos de pós-graduação contam que quando elaboram seus próprios relatórios, esses, de um modo geral, guardam muitas semelhanças com relatórios já produzidos por outros membros do laboratório de pesquisa onde atuam, conforme explicitado a seguir.

$\left.\mathbf{A P}_{2}\right)$ “É, muitas vezes a gente faz um trabalho e vai se guiando por outros. Eu peguei alguns trabalhos e tinha alguns relatórios que tinham algumas técnicas que a gente estava aprendendo. Uma série de pessoas fez idêntico, inclusive nos títulos! Então ocorre uma má impressão nisso, parece que você não está evoluindo muito... Era gritante, era tudo muito parecido! E acaba a Introdução sendo muito parecido numa tese de doutorado ou que seja numa tese de mestrado... tudo a mesma coisa! Você acaba olhando o anterior. 'Olha lá como fulano fez e faz assim'. Eu achei que ficou feio.”

E por fim, o professor questiona a falta de um padrão ou modelo que direcione a elaboração de um relatório de laboratório. Esta visão é manifestada com as palavras que seguem.

(PR) "Eu digo o que acontece, e diria que aqui deve acontecer isso também: é que ninguém nos ensinou a fazer isso, não é. Um laboratório faz assim, os outros, já são outras pessoas que fazem diferente e ninguém diz 'leia aqui como fazer um relatório"”.

Alguns questionamentos importantes foram levantados pelos alunos, tanto de graduação quanto de pós-graduação, em relação ao relatório de laboratório. O primeiro foi sobre a utilização de fichas para preenchimento de dados em vez da solicitação de um relatório mais formal e completo, fazendo com que não se proporcione ao aluno a oportunidade de desenvolver habilidades de escrita científica, interpretar dados obtidos e discutir os fenômenos químicos observados com base em conceitos científicos. Outro ponto levantado relaciona-se à "paráfrase”, por vezes realizada pelos alunos de pós-graduação, dos trabalhos escritos pelos colegas do laboratório de pesquisa, pois esta ação pode provocar uma barreira à evolução da capacidade de produção de textos científicos com maior independência. 
Percebe-se assim, de acordo com o que foi relatado, que o relatório de laboratório está presente no cotidiano de todos os sujeitos de pesquisa: dos alunos de graduação, que escrevem seus relatórios de laboratório de ensino; dos estudantes de pós-graduação, que elaboraram e redigem seus relatórios de pesquisa; e também do professor, cujo papel geralmente é de orientar na elaboração de tais relatórios, bem como corrigi-los. Estes fatos corroboram a noção de que a capacidade de comunicação escrita em linguagem científica é uma habilidade importante para o aluno de Química. Tilstra (2001) também relata em seu trabalho que, em geral, os alunos ingressantes na graduação não possuem ainda as habilidades necessárias à expressão em linguagem científica e aponta o relatório laboratório como uma ferramenta importante que pode ser utilizada para promover esse aprendizado, proporcionando ao aluno a capacidade de conectar seus conhecimentos sobre os conceitos químicos com os fatos e dados observados no laboratório e de apresentá-los de forma organizada, com padrão e linguagem científica apropriados.

Uma importante visão do professor em relação ao relatório de laboratório também é exposta no momento em que questiona sua própria formação. No depoimento a seguir observa-se que o professor, por não ter certeza se foi ensinado a como preparar um relatório adequadamente, também questiona o formato de relatório que ensina a seus alunos, uma vez que repassa a estes alunos aquilo que lhe foi ensinado por outros professores preparados da mesma forma que ele.

(PR) "É, isso faz muito sentido, porque, por exemplo, relatórios - que é um problema sério na vida do aluno. Vários aspectos nos levam a não ensinar bem o aluno a escrever um relatório. Primeiro porque nós aprendemos aos trancos e barrancos, ninguém nos ensino. Então, cada uma faz um relatório como acha que deve ser feito. [...] ( $O$ aluno) copia do colega, mas esse colega copiou do outro colega que foi ensinado por um professor mal preparado para isso também, no qual eu me incluo também. Eu não aprendi, eu acho que eu sei fazer um relatório”.

Fica claro, então, como o professor percebe a importância do relatório de laboratório para a formação de seus alunos, questionando inclusive seu próprio modelo de relatório. A 
visão do professor sobre a importância do relatório de laboratório para os alunos de Química também é relatada em outros trabalhos na literatura. Em disciplinas experimentais tem sido dada especial atenção ao relatório de laboratório produzido pelos alunos, através de fornecimento de roteiros detalhados para sua elaboração, bem como sua correção pelo professor seguida de discussão sobre os erros cometidos em sua redação. Para alguns professores do ensino superior de Química o relatório de laboratório tem sido apontado como ferramenta importante na formação acadêmica do graduando de Química, sobretudo diante do cenário de pesquisa científica na área de Química (LUZ JÚNIOR et al., 2004).

\subsubsection{Apresentações Orais e Escrita Científica}

Não apenas a dificuldades com a escrita científica foi discutida entre os sujeitos de pesquisa, mas também suas percepções e dificuldades em relação às apresentações orais. A seguir é apresentado um trecho de um diálogo no qual estavam presentes, além do pesquisador, apenas os alunos de graduação onde discutiram suas próprias dificuldades em relação à prática de apresentações orais. Observa-se que, embora os alunos reconheçam a tensão gerada diante da exposição oral em público, eles gostariam que fossem acrescentadas às aulas mais atividades em que pudessem exercitar a apresentação oral.

$\left(\mathbf{A G}_{\mathbf{2}}\right)$ - Eu lembro que a gente nunca apresentou...

$\left(\mathbf{A G}_{1}\right)$ - É algo que eu ia comentar... a gente tinha apresentações de seminários, a gente resolve o caso e depois apresenta. Só que no grupo somos em 4 ou em 5, ai só um apresenta. Só um passa pela experiência...

(PQ) - Mas no começo, o que vocês lembram, o que era mais difícil? Falar ou preparar os trabalhos escritos?

(AI $\left.\mathbf{I}_{1}\right)$ - Eu acho que é falar, por que você fica assim naquela tensão, de... De repente te dá um branco no meio da apresentação, ou fica imaginando o que o professor esta pensando

(PQ) - Porque de qualquer forma você está sendo avaliado ali. Então, o fato de você está sendo avaliado já gera uma tensão. 
$\left(\mathbf{A G}_{1}\right)$ - Eu não sei, eu acho que só treino mesmo. E a gente conseguir achar uma maneira de, por exemplo, mais pessoas apresentarem. É como a gente falou o professor vê, tanto da primeira e da segunda vez, mas o grupo tem 4 ou 5 elementos, mas só 2 apresentam, os outros ficaram sem passar por essa experiência.Todos treinaram, mas...

(AI $\left.\mathbf{I}_{1}\right)$ - Talvez na graduação se tivesse algumas matérias em que isso pudesse ser encaixado poderia até ser facilitado a comunicação porque exigiria mais da parte do aluno. Eu acho que até quando é muito concentrado, é perdida essa parte do aluno. O aluno fica muito na escrita e perde a parte da linguagem da fala.

Esta carência de atividades práticas com apresentações orais é também relatada pelos alunos de graduação em um outro momento, onde falam sobre a postura em apresentações científicas. Observe no trecho de um diálogo exposto a seguir como os alunos descrevem tais dificuldades.

$\left(\mathbf{A I}_{2}\right)$ - Os meninos da minha turma reclamam muito é sobre postura, porque chega lá na frente eles não sabem como ficar. E aí fica meio desajeitado e aquilo acaba atrapalhando a apresentação. E aí não sabe se coloca a mão na cadeira, na frente, ou se fica na frente da mesa ou atrás da mesa, e às vezes ficam com aquele "negocinho" na mão, mesmo às vezes não estando usando. E vai para um lado $e$ para o outro...[...]

$\left(\mathbf{A G}_{1}\right)$ - Às vezes as pessoas fazem uma apresentação e colocam slides muito pesados que jogam muita informação ou outro muito rápido. É você está lendo lá e quando ainda você não terminou de ler, a pessoa para e começa a falar, e parece que você não prestou a atenção.

$\left(\mathbf{A I}_{2}\right)$ - A professora, falou lá, da apresentação Karaokê; às vezes a pessoa coloca tudo o que vai falar no slide...

As dificuldades encontradas pelos alunos em relação às apresentações orais são também relatadas em vários trabalhos na literatura. Meyer (2003) em seu trabalho demonstra através de testes quantitativos que a exposição oral em público gera alto grau de ansiedade nos alunos e que através de atividades práticas de apresentações de seminários é possível desenvolver nos alunos habilidades de expressão oral, reduzindo assim o grau de ansiedade diante do público. Grace e Gilsdorf (2004) também relatam estratégias desenvolvidas em sala de aula visando desenvolver tais habilidades. Para atingir tal objetivo, este autor cita a realização de várias apresentações orais pelos alunos, sempre partindo de temas mais simples 
e com menor tempo de exposição para apresentações com temas mais complexos e com maior duração. Estes exemplos demonstram mecanismos de proporcionar ao aluno mais "treino" em apresentações orais - como foi sugerido por um dos sujeitos de pesquisa no presente trabalho.

Se por um lado os alunos de graduação relatam ser a expressão oral a maior dificuldade que enfrentam em relação à comunicação científica, opiniões divergentes em relação a este mesmo tema foram citadas pelo professor e pelos alunos de pós-graduação, em reunião onde, além do pesquisador, apenas estes estavam presentes. De acordo com suas visões, a escrita científica é mais difícil que a apresentação oral, conforme exposto no diálogo a seguir.

(PQ) - Nas suas aulas, então, você observa que os alunos têm mais dificuldade para escrever que falar? Ou é igual?

(PR) - A dificuldade, pra mim - eu sou muito radical nisso -, é falta de conhecimento de que falar, pra mim é o principio de tudo. Quando você conhece o tema que você vai falar, isso para qualquer um de nós, as coisas ficam mais fácies.

(AP1) - Antes do senhor chegar, eu estava discutindo que falar não é difícil, a pessoa se preparando para aquele momento antes. Já escrever não, precisa de uma maior bagagem de conhecimento, que ela vai ganhando com o tempo de... de conhecimento diário.

(PR) - O negócio que eu vejo, é que para escrever, você esta registrando, você precisa de uma pouco mais de precisão, então fica mais difícil. Quando você vai falar você pode explicar o que você está querendo dizer. Agora, quando você vai escrever, a priori, é para você mesmo, você não tem um interlocutor para te questionar, o que você quer dizer, daí a dificuldade. Muitas vezes quando a gente vai corrigir uma prova, que o indivíduo por falta da precisão ele escreve coisas que não são inteligíveis, daí ele diz "Mas está claro!". Está claro pra ele, mas não para mim.

Esta divergência de opiniões sobre a dificuldade maior, se escrita ou oral, levantou também questionamentos relacionados à precisão na redação de textos científicos. Observe a seguir o trecho de um diálogo onde professor e o aluno de pós-graduação manifestam suas visões sobre esse tema.

$\left(\boldsymbol{A} \boldsymbol{P}_{1}\right)$ - E não é só um problema da graduação. A gente estava discutindo a dificuldade, por exemplo, de reproduzir um experimento em um artigo. E ai cai justamente nisso, a pessoa deixa passar alguma coisa... 
(PR) - Não está claro! Aí "tal experimento pode ser feito em certas circunstâncias". Ele pode ser feito ou ele deve ser feito? Porque são coisas diferentes, se você falar que deve ser feito é que se não fizer assim vai dar errado. Deve ser feito na ausência de luz, é diferente de pode ser feito na ausência de luz.

Nesse contexto, Kovac e Sherwood (1999) analisam como a produção de textos está intimamente ligada à produção literária do cientista, e, desta forma, demonstram que a redação científica é bastante importante para os estudantes, não apenas na vida acadêmica, como também na vida profissional. Apesar da reconhecida importância, o que tem se observado é o relato na literatura sobre o despreparo dos alunos para a elaboração de textos científicos, em parte devido à pouca leitura de artigos científicos, pois geralmente estão mais habituados apenas à leitura de livros (WALLNER; LATOSI-SAWIN, 1999). Por esse motivo, várias estratégias têm sido desenvolvidas em sala de aula com o intuito de desenvolver habilidades de escrita em linguagem científica, tais como atividades de leitura de artigos científicos e redação de resumos sobre os tais artigos (SANTOS; SÁ; QUEIROZ, 2006).

Shirbley e colaboradores (2001) relatam uma estratégia na qual os alunos, além de redigirem textos científicos, têm seus escritos avaliados por outros dois colegas. Assim, cada aluno desenvolve habilidades de escrita em linguagem científica, ao mesmo tempo em que faz uma análise crítica dos trabalhos dos colegas. Isso possibilita ao aluno rever seus erros, bem como aprender com os erros e acertos do colega.

Aplicações de atividades pautadas no uso da literatura primária em uma disciplina de Físico-Química demonstraram ser esta um recurso bastante útil para reforçar a aprendizagem em Química, bem como desenvolver a "capacidade de expressão em linguagem escrita e de localização de referências primárias e secundárias" (SANTOS; SÁ; QUEIROZ, 2006). No referido trabalho, além das atividades de leitura de artigos e posterior redação de resumos sobre o conteúdo desses artigos, foram realizadas também apresentações orais nas quais os 
alunos expuseram as principais idéias contidas no texto lido, bem como suas opiniões a respeito das propostas aplicada em sala de aula.

\subsubsection{Marketing e Ética em Comunicação Científica}

Diante da reconhecida importância da escrita para aqueles que se dedicam ao estudo de Ciências, seja aluno ou professor, os sujeitos de pesquisa abordaram assuntos relacionados ao marketing em comunicação científica. Segundo suas concepções, a habilidade de escrita pode ser utilizada como ferramenta para promover o marketing de seu próprio trabalho e, desta forma, valorizá-lo diante dos leitores. Observe a seguir as palavras do professor ao comentar sobre alguns componentes de um trabalho científico, em particular, do título.

$(\boldsymbol{P R})$ "Em relação ao Título. O título tem que ser atraente também. Por exemplo, se eu coloco um título que não diz nada, não vai ter ... Porque você quer ver, ele deve ter algo que transmita eventualmente o objetivo do trabalho. Eu fico chateado com meus alunos quando eles colocam "Síntese e caracterização de não sei o quê". Gente, isso aí não diz nada! Se tem lá um pesticida, e você apenas cita "Caracterização de um pesticida", isso não serve para nada. Agora quando você coloca "Novo composto para matar formigas", aí o cara vai ler, porque o título já é atraente".

Além do marketing, questões relacionadas à ética também foram citadas e discutidas entre os sujeitos de pesquisa. Conforme pode ser observado no trecho de um diálogo exposto a seguir, os alunos e o professor demonstram uma visão crítica e realista sobre a forma como a Ciência vem sendo produzida e divulgada atualmente. Assim, de acordo com suas concepções percebem a importância do bom marketing para publicação dos trabalhos, mas reconhecem a necessidade de limites éticos na divulgação científica.

(PR) "Porque, de fato, o que a gente vê aí no ambiente cientifico é que aqueles que fazem marketing são tidos com os grandes, aquele que só trabalha... Você vê... tem gente que é garganta que só fala o que faz, mas na hora que você aperta para saber o que faz, você vê que não faz nada, é só fala. É o marketing".

$\left(\boldsymbol{A P}_{2}\right)$ "Tem que vê se... Tem um lado ruim disso aí. Porque tem que aprender a vender o peixe dele. Ele precisa, não é?".

(PR) "Precisa! Mas também você não pode ser só antiético, o que muita gente é". 
Neste sentido, são reportados na literatura diversos trabalhos onde são discutidos o marketing e a ética na comunicação científica. A idéia de que a quantidade de publicação científica influencia diretamente na vida profissional do pesquisador é amplamente reconhecida e divulgada. Em seu trabalho, Rosenfeldt et al. (2000) aponta, por exemplo, que um dos motivos para que os pesquisadores publiquem um número significativo de trabalhos é, além da divulgação do conhecimento, a obtenção de reconhecimento da comunidade científica. Desta forma, para o pesquisador publicar pode significar possibilidades de crescimento, obtenções de bolsas de estudo e recursos financeiros para pesquisas etc. Por exemplo, ao submeter um projeto às agências de financiamento, um dos critérios adotados na aprovação de recursos para projetos de pesquisa é a produção científica apresentada no currículo dos pesquisadores.

Diante, então, da grande pressão das agências de financiamento e dos órgãos governamentais para que os cientistas publiquem cada vez, muitos pesquisadores - às vezes por uma questão básica de sobrevivência no meio - têm enfrentado a busca constante por quantidade de publicação. As conseqüências desta busca têm se refletido na forma como a pesquisa científica é conduzida no Brasil. Em trabalho apresentado na revista Ciência Hoje, Hermes-Lima (2005) descreve alguns dados sobre as publicações brasileiras.

De fato aumentamos muito o número de publicações indexadas pelo Institute for Scientific Information (ISI) entre 1990 e 2002 passamos de $0,64 \%$ para $1,55 \%$ da produção mundial. Mas a quantidade média de citações por trabalho só aumentou de 1,8 (no período de 1992-1996) para 2,0 (entre 1998 e 2002), de acordo com dados do CNPq. [...]

$\mathrm{Na}$ contagem de King, o Brasil publicou $1,21 \%$ do total de artigos publicados entre 1997-2001 (dado semelhante ao do CNPq) dando-nos o $17^{\circ}$ lugar. [...]. Entretanto, os trabalhos dos brasileiros (de 1997 a 2001) receberam apenas $0,71 \%$ do total de citações mundiais, também abaixo da Austrália $(2,84 \%)$, China (1,56\%), Índia $(0,86 \%)$ e Coréia do Sul $(0,84 \%)$. (Ciência Hoje, v.36, n.212, 76-77, 2005) 
É possível perceber no texto anteriormente descrito que o autor chama a atenção para seu aumento quantitativo, sem, no entanto, verificar-se o crescimento de suas citações na mesma proporção.

Diante destes fatos, podemos entender como a comunicação científica tem sido analisada pelos sujeitos de pesquisa no presente trabalho. Em suma, eles reconhecem que a comunicação científica é uma das moedas mais fortes do pesquisador - ele necessita dela para sobreviver no meio - embora questionem a conduta ética na forma como ela é realizada.

\subsubsection{A Evolução da Ciência e sua Especialização}

Os debates sobre quantidade e qualidade em Ciência levantaram ainda questionamentos sobre a forma como os pesquisadores têm limitado seu estudo diante do grande número de informações publicadas na literatura científica e como a Ciência tem se tornada cada vez mais especializada. Descreve-se a seguir um trecho de um diálogo onde tais assuntos são abordados.

$(\boldsymbol{P R})$ - E nós mesmos, não só os jovens, temos que ler tanta coisa que você lê apenas os Abstract de uma coisa. Você não lê o todo para poder interpretar. Não é só o jovem que passa por isso, não.

(PQ) - É uma tendência, da especialização... é você saber cada vez mais de cada vez menos.

(PR) -Aí você realmente fica com dificuldade. Você pega a ciência, ela esta tão ampla também que às vezes você vai a algum seminário e você não entende nada. Às vezes o cara está falando de uma coisa tão avançada que já fugiu da realidade e você não entende nada do que se está se falando. Aqueles de 20 anos atrás, quando você ia a um seminário a coisa era restrita, os assuntos eram limitados. Hoje os assuntos são especificados.

Observa-se, então, que o próprio professor reconhece suas limitações de estudo diante do grande universo de conhecimento produzido continuamente. Este fato, de certa forma, está relacionado à forma como a comunidade científica encontrou para lidar com o grande número de informações: a especialização. Conforme mencionado anteriormente, os cientistas foram, 
ao longo dos tempos, cada vez mais se aprofundando em uma área da ciência e, mais adiante, em assuntos ou linhas de pesquisa dentro de uma mesma área. Esta especialização do conhecimento pode observada de forma mais intensa nas transformações ocorridas títulos dos periódicos os quais se destinam à, publicação de artigos com assuntos cada vez mais específicos. Algo semelhante também é observado na organização das reuniões científicas. Podemos citar, por exemplo, encontros mais abrangentes como a Reunião da Sociedade Brasileira para o Progresso da Ciência (SBPC), ou de uma única área da ciência como a Reunião Anual da Sociedade Brasileira de Química (SBQ), ou ainda de subáreas como o Congresso Brasileiro de Catálise (CBCat).

\subsection{A REPERCUSSÃO DAS DISCUSSÕES EM GRUPO NA ELABORAÇÃO DO} MATERIAL

Conforme mencionado no tópico Objetivos desta pesquisa, buscou-se elaborar um material didático sobre comunicação científica direcionado especificamente às necessidades de estudantes de graduação em Química. A partir de uma análise conjunta do material final produzido e das transcrições das reuniões de grupos, foi possível perceber em várias partes do material como as críticas e sugestões fornecidas pelos sujeitos da pesquisa se refletiram na sua elaboração. Ou seja, o texto foi elaborado baseado em informações coletadas na literatura relacionado ao tema, mas sobretudo levando-se em consideração a participação dos alunos e do professor. Assim, apresenta-se a seguir alguns dos reflexos da participação do grupo na construção final do material. 


\subsubsection{Considerações Sobre o Título}

Embora presente no início do material, o título foi abordado apenas na última reunião do grupo e alterado de acordo com a sugestão dos sujeitos da pesquisa. O título sugerido inicialmente foi Comunicação Científica em Química: um guia para estudantes de graduação, o qual foi modificado para Comunicação e Expressão em Linguagem Científica: um guia para estudantes de graduação em Química. Assim, conforme descrito no Quadro 1 a seguir, pode-se observar nas falas dos participantes que o título do material deveria destacar seu conteúdo de forma genérica e, em seguida, mais específica.

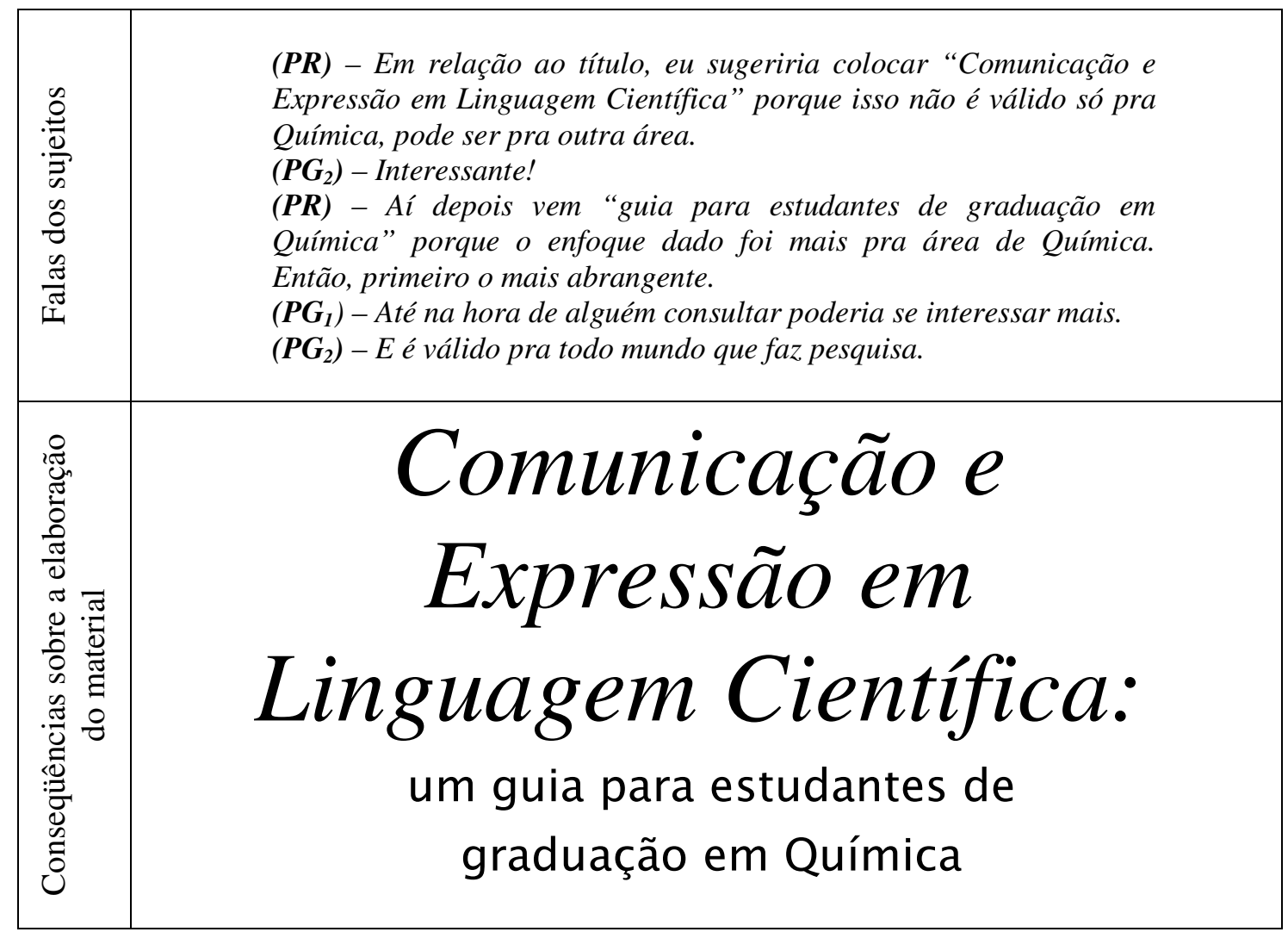

Quadro 1 - Falas dos sujeitos nas reuniões e suas conseqüências sobre o título do material.

É possível perceber, portanto, que, segundo os participantes, o título Comunicação e Expressão em Linguagem Científica transmite a idéia de que o conteúdo do referido 
trabalho possa ser aplicado em outras áreas da Ciência, além da Química. E mais adiante, no subtítulo um guia para estudantes de graduação em Química, deixa-se claro que o material foi desenvolvido de forma mais direcionada a estudantes de graduação em Química, conforme poderá ser evidenciado pelo leitor nos exemplos apresentados ao longo do texto.

A mudança ocorrida em relação ao título do material demonstra um aspecto característico de abordagens qualitativas, como a pesquisa participante: as mudanças de perspectiva do observador durante a evolução da pesquisa (MENGA; ANDRÉ, 1986). Assim, é importante ressaltar que a participação dos sujeitos neste estudo foi além da simples análise de seus debates, foi crucial para construção ou transformação do conhecimento produzido sobre o tema em questão.

\subsubsection{Considerações Sobre os Títulos de Alguns Tópicos}

Os títulos dos tópicos apresentados no material também foram alterados pelos grupo durantes as reuniões. No Quadro 2 a seguir apresenta-se um exemplo da participação dos sujeitos da pesquisa na denominação de alguns tópicos. Neste trecho do diálogo, ocorrido na terceira fase da pesquisa, os sujeitos debatiam sobre o tópico no qual seria apresentada a estrutura geral de relatórios, projetos, artigos etc., cuja denominação ficou Algumas Formas de Comunicação Científica. Ademais, discutia-se se também o tópico onde seriam descritas as características principais de resumos, introdução, parte de materiais e métodos etc, chamado de Componentes Principais do Texto Científico.

Este momento da pesquisa nos mostra como, através da pesquisa participante, é possível construir e reconstruir detalhes do objeto de estudo. Ou seja, é possível constantemente promover transformações consideradas importantes pelo grupo para a elaboração do material. Santo e Freire (2004), em um estudo no qual promoveram a 
construção participativa de um hipertexto, observaram que durante a realização do trabalho foi possível ao mesmo tempo em que produziam o conhecimento, também socializar a informação com todos os participantes.

\begin{tabular}{|c|c|}
\hline 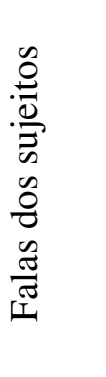 & $\begin{array}{l}(\boldsymbol{P Q}) \text { - Então, se você fosse detalhar cada parte do relatório, cada } \\
\text { parte do artigo, do projeto o texto iria ficar muito repetitivo, porque } \\
\text { tem casos que vai mudar um pouco, mas nem todos vão ter tudo isso } \\
\text { aqui, vai ter alguns que vai estar em todos. Então eu achei melhor... } \\
(\boldsymbol{A P}) \text { - Poderia ser "componentes principais de um texto cientifico"? } \\
(\boldsymbol{P Q}) \text { - É, ficaria melhor. } \\
{[\ldots]} \\
(\mathbf{P R}) \text { - Mas se você colocasse, por exemplo, "Formas de } \\
\text { Comunicação Científica"[..]. }\end{array}$ \\
\hline 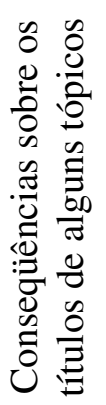 & $\begin{array}{l}2 \text { LGUMAS FORMAS DE COMUNICAÇÃO CIENTÍFICA } \\
3 \backsim \text { OMPONENTES PRINCIPAIS DOS TEXTOS } \\
\text { CIENTÍFICOS }\end{array}$ \\
\hline
\end{tabular}

Quadro 2 - Falas dos sujeitos nas reuniões e suas consequiências sobre os títulos de alguns tópicos do material.

\subsubsection{Considerações Sobre a Seqüência dos Tópicos}

Durante várias reuniões, a seqüência de apresentação dos tópicos e subtópicos foi amplamente discutida. Durante uma reunião na qual abordava-se o tópico do material onde seriam descritos os tipos de documentos científicos (artigos, relatórios, painéis etc), os sujeitos questionaram sua seqüência de apresentação, conforme pode ser observado nas falas transcritas a seguir.

$\left(\boldsymbol{A P}_{2}\right)$ - Mas antes de tudo, tem na parte do sumário, aqui o tópico 3, "Principais formas da comunicação científica”. Não seria melhor colocar dos mais simples 
para os mais complicados? Eu fiz outra numeração. Por exemplo eu acho que ficaria melhor Relatório, depois Artigos Científicos, Artigos de Revisão, depois Projetos de Pesquisa e por último Livro de Ensino. Só mudar a ordem. [...]

$(\boldsymbol{P Q})$ - Então, vou responder sua pergunta, por que eu iniciei do mais complexo para o simples. Porque na realidade eu analisei a maneira como todo o processo é realizado, um trabalho científico normalmente começa com um projeto que é desenvolvido, a seguir vem os relatórios, os artigos científicos, alguns desse trabalhos são publicados na forma de artigos de divulgação...

(PQ) - Pois é, mas esse material é para a graduação, pois primeiro o que vai interessar são os relatórios. Com tempo é que vou tendo contato com os artigos a medida que eu for avançando na graduação.

Em outra reunião, a sequiência de apresentação dos tópicos Algumas Formas de Comunicação Científica (2) e Componentes Principais dos Textos Científicos (3) foi também debatida entre o grupo. Na ocasião refletia-se sobre o que seria mais fácil para o aluno: apresentar primeiro os componentes de um texto, tais como introdução, materiais e métodos, ou apresentar primeiramente em linhas gerais o conceito de cada tipo de documento e seus componentes principais para, em outro tópico, abordar mais detalhadamente cada um desses componentes. Ao final, optou-se por apresentar primeiro as formas de comunicação e depois seus componentes. A seguir apresenta-se um trecho da reunião onde tais questões foram discutidas.

$(\boldsymbol{P R})$ - O 3 vem antes do 2, você inverteu. Sempre que você escrever um projeto, um artigo, você tem que saber primeiro os componentes deles.

(PQ) - Mas seria interessante já saber o conceito dele, o que é cada um deles, pra depois entender o porquê de cada componente.

(PR) - Mas quando você vai falar disso você já devia falar de conceitos. E quando você vai escrever um projeto, um relatório, ou qualquer coisa, um artigo, você tem saber o que ele deve conter.

$(\boldsymbol{P Q})$ - Então! Mas aí nessa primeira parte seria uma visão geral... "um projeto deve conter essas e essas partes", depois na outra parte seria detalhar.

As constantes discussões e transformações ocorridas durante a elaboração do material também são relatados em estudos no qual a pesquisa participante foi aplicada. No trabalho de Santo e Freire (2004), já citado anteriormente, foi possível observar que durante a construção participativa a análise das reuniões e os eventos ocorridos na pesquisa serviram de 
base para tomadas de decisões, tais como manter, aperfeiçoar, reelaborar, ou estabelecer novos procedimentos para o desenvolvimento de seu objeto de estudo.

\subsubsection{Considerações Sobre a Seção Apresentação}

Na primeira versão da seção Apresentação do material entregue para avaliação pelos sujeitos de pesquisa sugeria-se apenas o "observar" como caminho para o aprendizado. No entanto, a partir das críticas e sugestões apresentadas nas reuniões, acrescentou-se o "criticar" e o "assimilar" (semelhante ao "absorver" sugerido na reunião), uma vez que o desenvolvimento de habilidades de comunicação científica requer muito mais que a simples observação, requer também uma análise crítica do que lhe é apresentado como forma de promover uma assimilação de conhecimento mais significativa. No quadro a seguir são apresentadas as falas dos participantes sobre tais questionamentos e suas consequiências na elaboração da seção Apresentação..

\begin{tabular}{|c|c|}
\hline 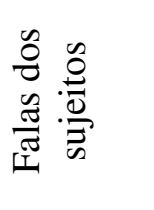 & $\begin{array}{l}(\boldsymbol{P Q}) \text {-Foi mais uma sugestão... } \\
(\boldsymbol{P R}) \text { - Pois é se resume a três palavras, você tem que observar, } \\
\text { criticar e absorver. É claro que observar é diferente de absorver. } \\
\text { Você tem que absorver com um senso crítico. Tem muita gente que } \\
\text { observa igual coruja. Mas não sai nada. }\end{array}$ \\
\hline 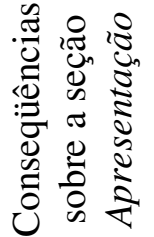 & $\begin{array}{l}\text { A regra do OBSERVE, no entanto, pode ser em alguns momentos } \\
\text { incompleta, sobretudo quando se trata da formação de pesquisadores. } \\
\text { Desta forma, acrescentaríamos mais duas palavras que tornam o } \\
\text { aprendizado da comunicação científica mais completo: CRITICAR e } \\
\text { ASSIMILAR. }\end{array}$ \\
\hline
\end{tabular}


A construção do conhecimento e as mudanças de opinião ocorridas durante o desenvolvimento de trabalhos baseados em metodologia de pesquisa participativa também são reportados por outros autores. Araújo (2001), ao analisar como a violência vivenciada fora da escola reorienta atitudes e comportamentos dos alunos, reconhece que graças à participação desses alunos foi possível sair do senso comum e construir novas referências, permitindo assim compreender como constroem suas identidades, tendo a violência como pano de fundo.

\subsubsection{Considerações Sobre Marketing e Ética}

Conforme já mencionado anteriormente, foram também bastante discutidas entre os sujeitos questões relacionadas ao marketing e à ética em comunicação científica, bem como debates sobre a forma como a produção científica é avaliada atualmente, no que diz respeito a aspectos quantitativos e qualitativos. Ao discutirem sobre o tópico Considerações Sobre a Comunicação Científica, foi sugerida a inclusão de aspectos relacionados aos referidos temas. No Quadro 4 a seguir apresenta-se um trecho de tais debates, cujas críticas e sugestões refletiram-se na elaboração do texto onde foram abordadas questões de marketing e ética em comunicação científica.

É possível observar, no contexto dos debates sobre questões éticas em comunicação científica, que as reflexões críticas sobre temas relacionados ao cotidiano dos sujeitos da pesquisa estão presentes freqüentemente em trabalhos baseados em pesquisa participativa. Outros trabalhos na literatura também reportam a pesquisa participativa como metodologia capaz de proporcionar "estímulo à reflexão crítica da realidade, assim como da efetivação da construção, apropriação e socialização do conhecimento" (MELLO et al., 1998). 


\begin{tabular}{|c|c|}
\hline  & $\begin{array}{l}(\boldsymbol{P R}) \text { - Eu sugeriria que você colocasse alguma coisa assim: "a } \\
\text { comunicação com um marketing de financiamento". } \\
(\boldsymbol{P Q}) \text { - Ficou mais suave. } \\
(\boldsymbol{P R}) \text { - Porque aí nesse tópico você aborda como chegar a essas fontes } \\
\text { de financiamento. Porque de fato, o que a gente vê aí no ambiente } \\
\text { cientifico é que aqueles que fazem marketing são tidos com os grandes. } \\
\left.(\boldsymbol{A P})_{2}\right) \text { - Tem que vê se tem um lado ruim disso aí. Porque tem que } \\
\text { aprender a vender o peixe dele. Ele precisa, não é? } \\
(\boldsymbol{P R}) \text { - Precisa, é, mas também você não pode ser só... antiético, o que } \\
\text { muita gente é. } \\
\left.(\boldsymbol{A P})_{2}\right) \text { - Claro! Essa é a questão da ética. } \\
(\boldsymbol{P R}) \text { - Pode colocar ética da comunicação. } \\
(\boldsymbol{P Q}) \text { - Isso tudo é inserido nessa primeira parte ou separa? } \\
(\boldsymbol{P R}) \text { - Seria a ética da comunicação, dá para por nessa parte aí. }\end{array}$ \\
\hline 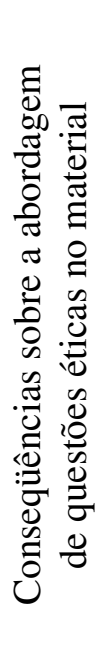 & $\begin{array}{l}\text { Para os pesquisadores a publicação vem se tornado cada vez mais } \\
\text { importante. Publicar pode significar possibilidades de crescimento, de } \\
\text { reconhecimento nacional ou internacional, obtenções de bolsas de estudo, } \\
\text { recursos financeiros para pesquisas etc. Ao submeter um projeto às agências de } \\
\text { financiamento, como o CNPq e a FAPESP, é obrigatória a apresentação do } \\
\text { currículo atualizado dos pesquisadores. A análise da produção científica, } \\
\text { obviamente, é um dos critérios adotados na aprovação de recursos para projetos } \\
\text { de pesquisa.[...] } \\
\text { Um dos exemplos mais recentes e que despertou ainda mais a } \\
\text { preocupação da comunidade científica em relação à ética na comunicação } \\
\text { científica foi a descoberta de falsos resultados sobre clonagem de células-tronco } \\
\text { publicada na Science, umas das revistas científicas mais prestigiadas no mundo } \\
\text { (NEIVA, 2006). [...] Este episódio demonstra que as publicações científicas } \\
\text { podem ser alvo de má conduta ética. }\end{array}$ \\
\hline
\end{tabular}

Quadro 4 - Falas dos sujeitos nas reuniões e suas consequiências sobre a abordagem de questões éticas no tópico Considerações Sobre a Comunicação Científica do material.

\subsubsection{Considerações Sobre o Relatório de Laboratório}

Vários aspectos sobre o relatório de laboratório foram relatados pelos sujeitos de pesquisa, conforme já discutido anteriormente. Embora tais discussões tenham fornecido mais informações sobre as visões dos sujeitos em relação ao relatório de laboratório, suas críticas e sugestões também refletiram-se no conteúdo do material. Assim, no subtópico Relatórios, 
conforme pode ser observado no quadro a seguir, questões sobre a presença do caderno de laboratório em substituição ao relatório foram mencionadas de acordo com os debates.

\begin{tabular}{|c|c|}
\hline 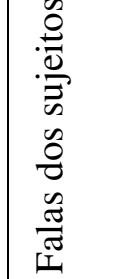 & $\begin{array}{l}(\boldsymbol{P R}) \text { - Quando o aluno for ler isso ele já vai ter feito um relatório na vida } \\
\text { dele, então ele já sabe. } \\
\left(\boldsymbol{A} \boldsymbol{G}_{\boldsymbol{I}}\right) \text { - Não vamos esquecer de colocar aqui no nosso estudo é que } \\
\text { quando a gente chega... tem um caderno de laboratório que é tipo um } \\
\text { formulário que a gente preenche dados, que na verdade a gente não faz } \\
\text { um relatório... }\end{array}$ \\
\hline 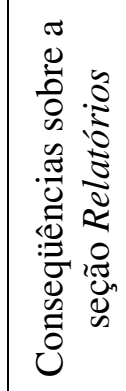 & $\begin{array}{l}\text { Os relatórios de aulas práticas de laboratório de ensino, embora também } \\
\text { sejam relatos de trabalhos já realizados - tal qual nos relatórios de pesquisa - têm } \\
\text { alguns aspectos diferenciados quanto ao seu objetivo, conteúdo e forma de } \\
\text { apresentação. Tem se observado nas disciplinas experimentais dos Cursos de } \\
\text { Química, até em uma mesma instituição, a falta de uniformidade ou padrão no } \\
\text { formato dos relatórios exigidos em cada disciplina. Em alguns casos, a elaboração } \\
\text { de um relatório chega a ser substituída pelo preenchimento de fichas-relatório ou } \\
\text { pelo caderno de laboratório. }\end{array}$ \\
\hline
\end{tabular}

Quadro 5 - Falas dos sujeitos nas reuniões e suas conseqüências sobre a seção Relatórios do material.

\subsubsection{Uso de Revistas Para Obtenção dos Exemplos}

Uma das características mais marcantes do material produzido é a riqueza de exemplos apresentados em vários tópicos, os quais foram em sua maioria direcionados à área de Química. No Quadro 6 são apresentados trechos dos debates do grupo onde tais questões foram abordadas e dois exemplos apresentados no material: o primeiro obtido de um artigo da revista Química Nova e o segundo obtido da revista Eclética Química.

Embora inicialmente já existisse a idéia de trabalhar com exemplos para ilustrar as informações expostas no texto, foi baseada nas sugestões dos sujeitos de pesquisa que tal idéia foi reforçada. Desta forma, a participação do grupo foi de crucial importância na utilização de artigos publicados em revistas da área de Química para obtenção dos exemplos. 


\begin{tabular}{|c|c|}
\hline 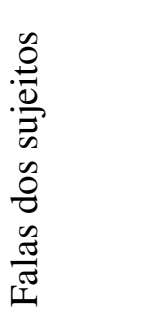 & $\begin{array}{l}(\boldsymbol{P R}) \text { - Eu acho que valeria à pena você se fixar nas revistas } \\
\text { nacionais. } \\
(\boldsymbol{P R}) \text { - Já que é em Química, você pegaria Química Nova... } \\
(\boldsymbol{P Q}) \text { - É eu peguei mais exemplos da Química Nova, porque são } \\
\text { em português, e assim fica mais fácil para os alunos do primeiro } \\
\text { ano. O que eu tive de pegar um pouco diferente da Química Nova } \\
\text { foi a Eclética para mostrar os exemplos de resumos, porque a } \\
\text { Química Nova só tem os resumos em inglês. }\end{array}$ \\
\hline \multirow{2}{*}{ 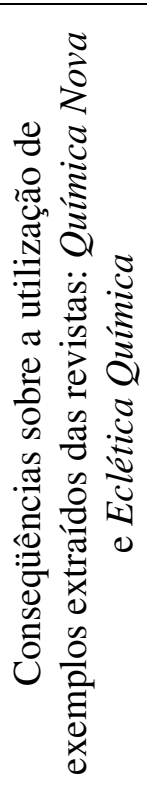 } & $\begin{array}{l}\text { Observe estes exemplos encontrados em publicações científicas: } \\
\text { Karina Omuro Lupetti, Lucinéia Cristina de Carvalho, André Farias de } \\
\text { Moura e Orlando Fatibello-Filho } \\
\text { (Química Nova, v.28, n.3, 548-554, 2005) }\end{array}$ \\
\hline & $\begin{array}{l}\begin{array}{l}\text { O autor apresenta, em um só parágrafo, o } \\
\text { objetivo do trabalho e a principal técnica } \\
\text { empregada... }\end{array} \\
\text { Resumo: O objetivo deste trabalho foi caracterizar ácidos húmicos (HA) de } \\
\text { diferentes origens por eletroforese capilar de zona (CZE) e avaliar a influencia da } \\
\text { concentração do tampão borato nesta caracterização. Os resultados mostraram } \\
\text { que HA de diferentes origens podem ser rapidamente caracterizados por CZE. } \\
\text { Por essa técnica, a caracterização de HA é devido a diferenças na razão } \\
\text { carga/tamanho e das propriedades dos componentes individuais e duas origens. } \\
\text { (Eclet. Química, v. 29, n.2, 47-52, 2004). } \\
\text { e descreve os principais resultados do trabalho }\end{array}$ \\
\hline
\end{tabular}

Quadro 6 - Falas dos sujeitos nas reuniões e suas consequiências sobre a utilização de exemplos extraídos de revistas da área de Química no material.

Além da revista Química Nova e da revista Eclética Química, foram também utilizados artigos publicados na revista Pesquisa Fapesp, onde foram obtidos os exemplos de textos característicos de artigos de divulgação científica. A seguir apresenta-se um dos exemplos exposto no material, o qual foi reproduzido da revista Pesquisa Fapesp.

TRAQUINAGENS ETÍLICAS

Nos próximos dias é quase certo que alguém lhe estenderá uma taça de espumante - ou de champanhe, a original francesa, se as finanças familiares estiverem no azul e dólar, bem comportado.(...)Mas é preciso ter cuidado: tão ruim quanto exagerar na dose é consumir produtos de qualidade ou autenticidade duvidosa.(..) Nos últimos cinco anos, pesquisadores brasileiros passaram a estudar o grau de adulteração em produtos...

(Pesquisa Fapesp, n.74, 72-75, 2003) 
As sugestões sobre utilização de exemplos estiveram presentes em várias reuniões e refletiram-se, conseqüentemente, em várias partes do material. No quadro a seguir apresentase um outro momento onde os participantes discutiam sobre a presença de exemplos no material. Observe no Quadro 7, uma parte do material onde são abordadas algumas características dos artigos de revisão e como o exemplo complementa a informação apresentada - às vezes vaga para quem desconhece o assunto - e assim reforça no leitor a capacidade de observação e assimilação da idéia transmitida em cada parte do texto.

Assim, baseado na sugestão do grupo, buscou-se acrescentar em cada tópico exemplos que facilitassem a compreensão das informações expostas bem como a visualização das diferenças entre os tipos de documentos científicos e das principais características de cada parte de um texto científico. Compreende-se que, por ser direcionado a alunos de graduação, muitos dos quais supostamente ainda não entraram em contato com a diversidade de documentos científicos, os exemplos mostraram-se de extrema importância no desenvolvimento do material.

\begin{tabular}{|c|c|}
\hline 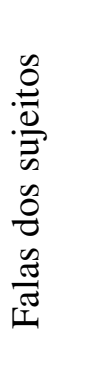 & $\begin{array}{l}\left(\boldsymbol{A P}_{2}\right)-E \text { É que esse material didático ele é voltado para o aluno que esta } \\
\text { ingressando. É você poderia colocar um exemplo de cada um, citar um } \\
\text { pedacinho de cada. } \\
(\boldsymbol{P Q}) \text { - De cada assunto? } \\
(\boldsymbol{A P})-\text { - Eu acho que sim. } \\
(\boldsymbol{P Q}) \text { - É, eu vou ter que buscar... } \\
(\boldsymbol{P R}) \text { - Exemplos, eu acharia que é para usar mesmo. } \\
(\boldsymbol{P R}) \text { - É interessante o exemplo pra chamar a atenção, a diferença de um e } \\
\text { de outro. Você não colocou aqui, mas seria interessante, é review. }\end{array}$ \\
\hline 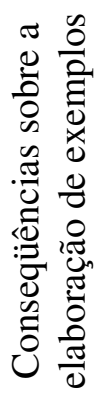 & $\begin{array}{l}\text { Os artigos de revisão abordam de um modo geral os seguintes aspectos: } \\
\text { ESTADO DA ARTE: apresenta uma síntese do conhecimento sobre um } \\
\text { determinado assunto, com ênfase na literatura mais recente. } \\
\text { Em revisão recente desta técnica, Chester e Pinkstone', em 2002, ressaltaram o } \\
\text { crescimento de aplicações de SFC [...]. Nos sistemas unificados, desenvolvidos } \\
\text { até então, foram empregados hélio para CG e CO } \text { CO }_{2} \text { para SFC, } \\
\text { independentemente } 26-30 \text {, metanol e éter dietílico como gás e líquido }{ }^{24} \text {. } \\
\text { (Química Nova, v.27, n.5, 747-753, 2004) }\end{array}$ \\
\hline
\end{tabular}


Quadro 7 - Falas dos sujeitos nas reuniões e suas conseqüências sobre a elaboração de exemplos no material.

\subsubsection{Considerações Sobre a Seção Introdução}

O tópico Componentes Principais dos Textos Científicos, sobretudo onde foram abordadas as principais formas de apresentação da seção Introdução nos textos científicos, foi motivo de intensas discussões entre os sujeitos de pesquisa, até que chegassem a um consenso. No quadro a seguir são apresentados trechos da reunião na qual a seção Introdução foi alvo de discussões entre os sujeitos e como estas se refletiram na elaboração desta parte do material.

\begin{tabular}{|c|c|}
\hline 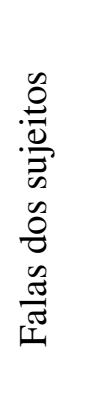 & $\begin{array}{l}(\boldsymbol{P Q})-\text { Então, citar outros exemplos? } \\
\left(\boldsymbol{A} \boldsymbol{P}_{1}\right) \text { - Pois, ou você cita separadamente que num artigo a introdução é mais } \\
\text { completa, não tem a parte de objetivos e revisão bibliográfica separada, } \\
\text { então é mais completa a introdução. Já numa tese não, essas partes são } \\
\text { separadas.[..] } \\
\left(\boldsymbol{A} \boldsymbol{P}_{I}\right)-\tilde{E} \text {, o problema é esse. Mas de qualquer forma como mais a frente } \\
\text { você fala, "segue-se com a revisão da literatura e da bibliografia e mais o } \\
\text { que se conhece sobre o que foi estudado e por último o que se pretende } \\
\text { fazer". Isso é um tópico: objetivo. Eu acho que precisa da Introdução ter } \\
\text { essas partes. }\end{array}$ \\
\hline 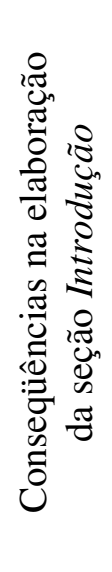 & $\begin{array}{l}\text { Nos artigos e relatórios de pesquisa é comum a introdução ser redigida } \\
\text { em um único tópico, como demonstrado no exemplo a seguir. No entanto, em } \\
\text { monografias, teses, dissertações, projetos de pesquisa é comum dividir os } \\
\text { elementos da introdução em tópicos bem distintos. Inicialmente apresenta-se } \\
\text { uma introdução curta na qual o tema do trabalho é apresentado e sua } \\
\text { importância é justificada. Segue-se com a Revisão da Literatura (ou Revisão } \\
\text { Bibliográfica), bem mais extensa e aprofundada sobre o que se conhece sobre o } \\
\text { tema estudado. Em alguns casos, a Introdução pode ser ainda dividida em } \\
\text { subtópicos, como demonstrado no exemplo extraído de uma dissertação de } \\
\text { mestrado exposto mais adiante. E por último apresenta-se claramente o que se } \\
\text { pretende fazer no tópico Objetivos, que pode às vezes ser subdividido em } \\
\text { Objetivos Específicos. }\end{array}$ \\
\hline
\end{tabular}


Quadro 8 - Falas dos sujeitos nas reuniões e suas conseqüências na elaboração da seção Introdução do material.

Durante uma das reuniões, na qual esta seção foi debatida, apresentou-se inicialmente como exemplo apenas uma Introdução obtida de um artigo científico publicado na revista Química Nova. Entretanto, foi relatada também a importância de mostrar ao aluno que existem outras formas de elaborar esta seção, dependendo do tipo de documento que esteja sendo produzido. Assim, conforme foi demonstrado no Quadro 8, considerou-se importante não apenas citar que a Introdução de um artigo científico é diferente em sua forma de apresentação que a Introdução de uma dissertação, por exemplo, mas também acrescentar um outro exemplo.

\subsubsection{Considerações Sobre a Descrição de Apud}

Os tópicos com conteúdo mais direcionado à redação em linguagem científica foram elaborados com considerável influência da pesquisa bibliográfica realizada na literatura relacionada ao tema, embora em vários momentos também tenham existido importantes considerações, sugestões e críticas fornecidas pelos sujeitos. Pode-se citar como exemplo a inclusão de informações mais detalhadas sobre o apud (citação da citação) durante a elaboração da seção na qual descreviam-se as formas de apresentação de citações e referências bibliográficas em textos científicos.

Assim, mais uma vez a participação dos sujeitos foi decisiva para promover mudanças importantes na construção do material. O Quadro 9 descreve um trecho da reunião onde abordou-se a apresentação do apud e em seguida, o reflexo de tais sugestões no material. 


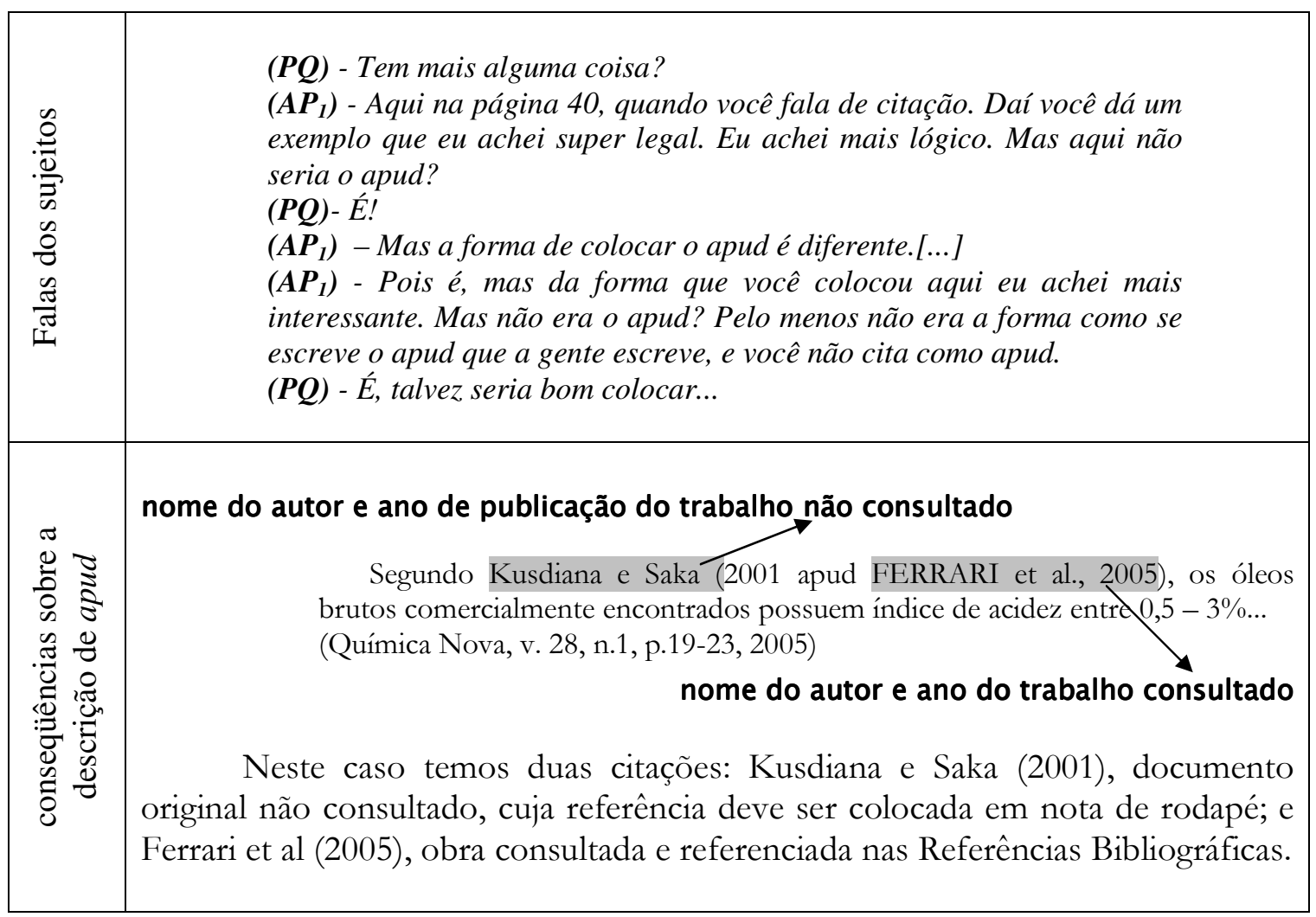

Quadro 9 - Falas dos sujeitos e suas conseqüências sobre a descrição de apud no material.

Nesse contexto, é possível observar que a pesquisa participante promove uma reflexão coletiva, a qual influencia na construção dos conceitos sobre um determinado tema de estudo e no entendimento de seus aspectos técnicos, conforme também reportado em outros estudos pautados nesta metodologia de pesquisa (MELLO et al., 1998).

\subsubsection{Considerações sobre Características da Linguagem Científica}

A inclusão do tópico Algumas Características da Linguagem Científica foi uma das primeiras sugestões fornecidas pelos sujeitos, sobretudo durante reuniões onde foram debatidas as principais dificuldades encontradas pelo aluno para expressar seus conhecimentos. No Quadro 10 apresentamos como as discussões relacionadas à linguagem científica contribuíram para a elaboração do referido tópico do material. No trecho 
apresentado no Quadro 10 os sujeitos discutem particularmente sobre a precisão na linguagem científica.

\begin{tabular}{|c|c|}
\hline 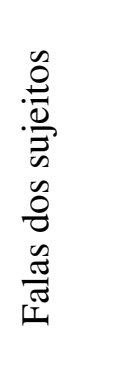 & $\begin{array}{l}(\boldsymbol{P R}) \text { - E depois dentro de relatórios existem palavras que devem ser } \\
\text { usadas, porque indicam a precisão. Então, você tem que indicar nos } \\
\text { relatórios científicos as palavras que têm peso, muitas vezes para indicar } \\
\text { precisão. Claro que você sabe que tem que ser assim, não que pode ser } \\
\text { assim, deve ser feito assim. Aí, "tal experimento pode ser feito em certas } \\
\text { circunstâncias". Ele pode ser feito ou ele deve ser feito? Porque são coisas } \\
\text { diferentes, se você falar que deve ser feito é que se não fizer assim vai dar } \\
\text { errado. Deve ser feito na ausência de luz, é diferente de pode ser feito na } \\
\text { ausência de luz. }\end{array}$ \\
\hline 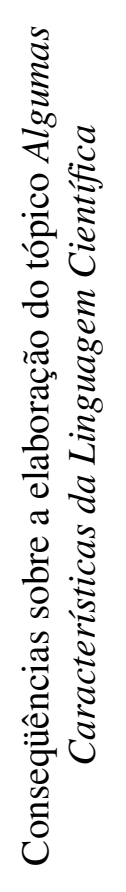 & 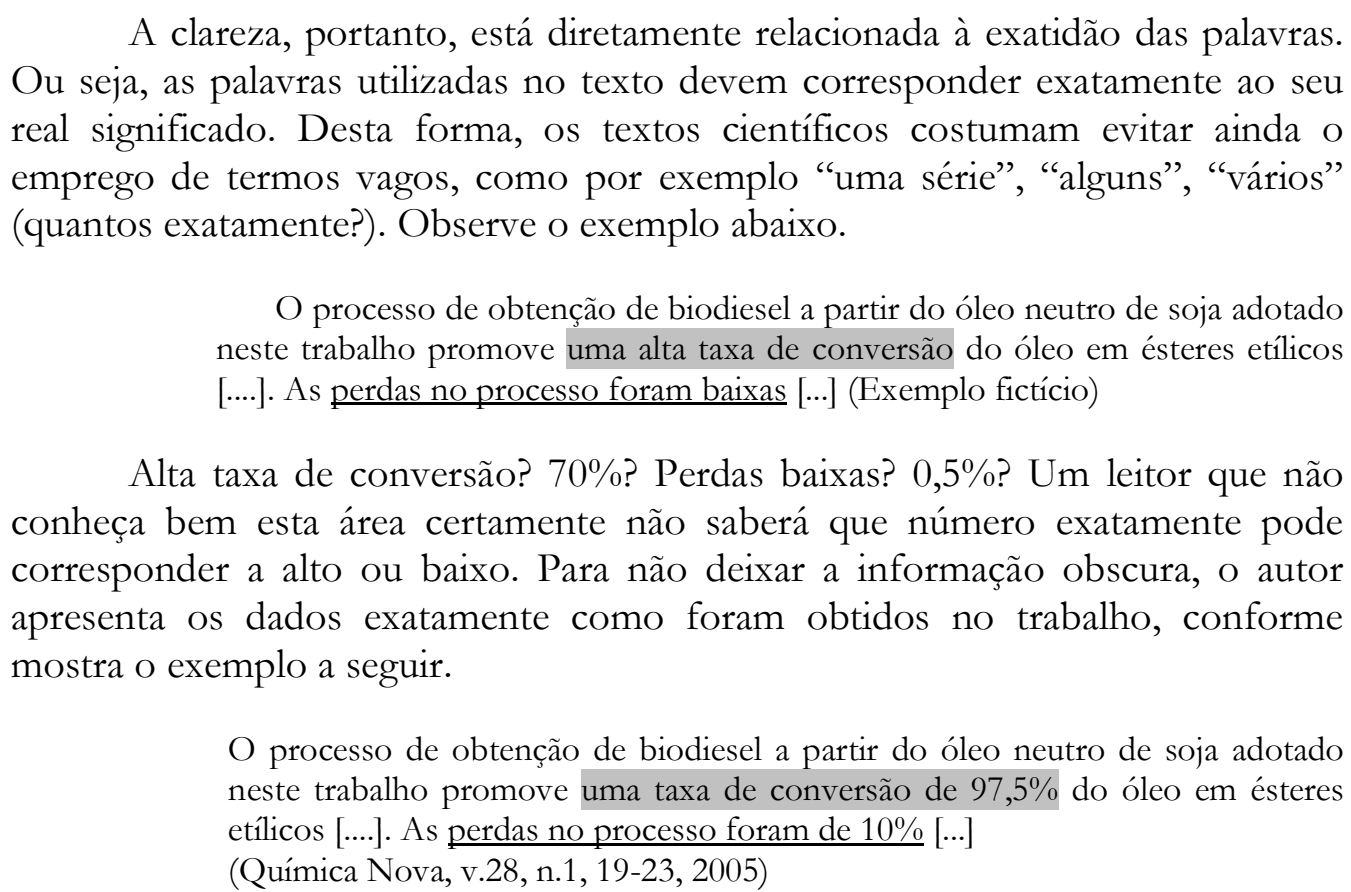 \\
\hline
\end{tabular}

Quadro 10 - Falas dos sujeitos e suas conseqüências sobre a elaboração do tópico Algumas Características da Linguagem Científica do material.

Talvez a questão da linguagem científica tenha surgido como umas das primeiras preocupações do grupo por ser uma habilidade que requer geralmente um tempo considerável para ser desenvolvida, sendo uma dificuldade ainda presente entre muitos alunos de pósgraduação. 
Convém ressaltar que abordar as características da linguagem científica e relacionálas à área de Química foi uma tarefa desafiadora para o grupo, embora de reconhecida importância. Apesar das limitações, tanto do pesquisador quanto dos sujeitos de pesquisa, e da carência de informações na literatura sobre a escrita científica para a área de Química, foram abordados no referido tópico alguns aspectos da linguagem através de exemplos obtidos de artigos da área.

Nesse contexto, compreende-se como a pesquisa participante mostra-se importante como meio de promover benefício direto e imediato à população, ao mesmo tempo em que apresenta os sujeitos envolvidos no processo de busca de soluções e interpretações de seus problemas (DEMO, 2001).

\subsubsection{Considerações Sobre os Tempos Verbais nos Textos Científicos}

Discussões sobre questões relacionadas à escrita científica estiveram presentes em outros momentos das reuniões de grupo e, conseqüentemente, contribuíram para a elaboração de novas abordagens existentes no material. Como outro exemplo, pode-se citar a elaboração de uma seção especialmente direcionada a descrever os diferentes tempos verbais utilizados nos textos científicos. Assim, foram apresentados os tempos verbais mais freqüentemente utilizados em cada tipo de documento ou em cada seção do texto. Além disso, as informações expostas nessa seção foram ilustradas através de exemplos da área de Química.

A forma como as sugestões fornecidas pelos grupos durante reuniões influenciaram na elaboração da seção Os Tempos Verbais nos Textos Científicos pode ser observada no Quadro 11, apresentado a seguir. 


\begin{tabular}{|c|c|}
\hline 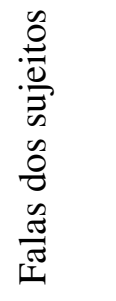 & $\begin{array}{l}\left(\boldsymbol{A} \boldsymbol{P}_{I}\right)-\text { Você pode dar uma dica para cada, para cada forma de } \\
\text { comunicação, qual o tempo verbal mais adequado. } \\
(\boldsymbol{P R}) \text { - Na hora de escrever o projeto é no futuro, quando você escreve } \\
\text { um artigo você escreve no passado ou no presente, mas não pode } \\
\text { misturar. } \\
\left(\boldsymbol{A} \boldsymbol{P}_{I}\right) \text { - Você poderia... nessa parte de erros, falar de tempo verbal, você } \\
\text { poderia ter um tópico sobre estes componentes. }\end{array}$ \\
\hline 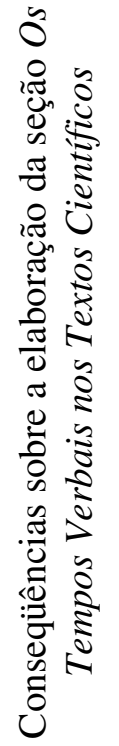 & 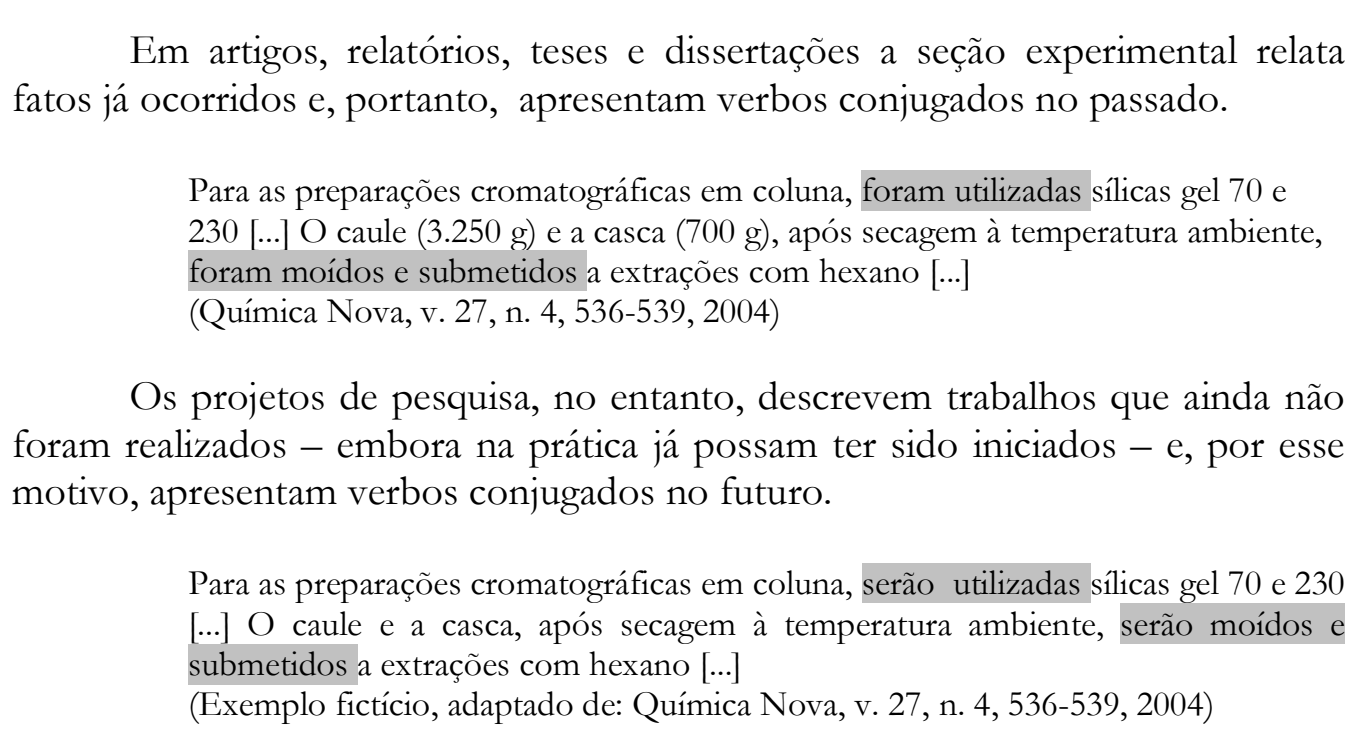 \\
\hline
\end{tabular}

Observa-se, assim, mais uma vez, uma característica da pesquisa participativa importante para o presente trabalho: o processo de conhecer e agir. Ou seja, a população engajada no estudo não apenas busca o conhecimento de um tema em particular, mas também parte para ações de mudanças em seu benefício, a qual manifesta-se substancialmente em ações educativas (DEMO, 2001).

\subsection{CARACTERÍSTICAS GERAIS DO MATERIAL}

O material didático produzido, o qual está apresentado no Apêndice D desta dissertação, foi dividido em cinco tópicos principais: (1) Considerações sobre a Comunicação 
Científica; (2) Algumas Formas de Comunicação Científica; (3) Componentes Principais dos Textos Científicos; (4) Localizando e Utilizando a Literatura em Química; e (5) Algumas Características da Linguagem Científica.

O primeiro deles, Considerações sobre a Comunicação Científica, foi elaborado com a finalidade de proporcionar ao aluno uma visão geral de como a comunicação científica evoluiu ao longo dos séculos. Para atingir esta finalidade fez-se um breve histórico do tema, destacando tanto aspectos relacionados à publicação científica quanto à evolução da própria comunidade científica. Ademais, foram abordadas ainda nesse tópico questões relacionadas às avaliações quantitativas e qualitativas das publicações, como, por exemplo, Fator de Impacto e avaliação por pares, bem como aspectos éticos, ressaltando a importância da publicação para a vida profissional do cientista. De um modo geral podemos afirmar que esse tópico pode ser um direcionador de reflexões críticas sobre aspectos relacionados à comunicação científica.

No segundo tópico, dá-se início à parte mais direcionado ao reconhecimento e elaboração de documentos científicos. Nesse tópico são apresentadas Algumas Formas de Comunicação Científica, tais como: relatórios, artigos científicos, trabalhos apresentados em reuniões científicas (resumos, painéis, apresentações orais), projetos de pesquisa, artigos de divulgação da ciência etc. Ao abordar cada forma de comunicação buscou-se descrever seu conceito e seus componentes principais, bem como apresentar exemplos que mostrassem suas características principais. O objetivo principal desse tópico foi, portanto, apresentar ao aluno a diversidade de documentos produzidos pelos cientistas e auxiliá-los no seu reconhecimento e diferenciação.

Após a apresentação de uma visão geral sobre as principais formas de comunicação científica, foram abordadas de forma mais detalhada os Componentes Principais dos Textos Científicos, tais como: título, autores, resumo, introdução, palavras-chave, materiais e métodos, resultados e discussão etc. Além de descrever as principais características de cada 
um desses componentes, foram destacados alguns cuidados adotados pelos autores ao elaborálos e tais informações foram complementadas com vários exemplos na área de Química. Assim, objetivou-se nesse tópico auxiliar o aluno no reconhecimento das principais formas de apresentação de cada seção de um trabalho científico e oferecer subsídios para a elaboração de seus próprios textos.

No decorrer dos tópicos anteriores, foram apresentados diversos tipos de textos científicos, detalhes de seus componentes principais e suas relações com outras publicações existentes na literatura. Assim, foi considerado importante, no tópico Localizando $e$ Utilizando a Literatura em Química, apresentar ao aluno a classificação das fontes de informação em Ciência, auxiliando-os a reconhecer e diferenciar fontes primárias, secundárias e terciárias. Além disso, foram descritas algumas bases de dados que podem ser utilizadas para a realização de pesquisas bibliográficas na área de Química.

Por fim, foram apresentadas também neste material Algumas Características da Linguagem Científica. Nesse tópico foram destacadas as características da linguagem tais como impessoalidade, clareza, concisão e continuidade, através de conceitos e exemplos obtidos de publicações da área de Química. Além disso, foi abordada a utilização dos tempos verbais nos diferentes tipos de documentos e nas seções que os compõem. Por fim, ainda nesse tópico foram apresentados os conceitos e alguns exemplos de jargões bastante freqüentes na área de Química. Embora para redigir textos cuja linguagem apresente as características relatadas nesse tópico seja necessário um contínuo exercício, objetivou-se desenvolver nos alunos uma visão crítica sobre seus próprios trabalhos, chamando sua atenção para tais aspectos da redação científica.

Convém ressaltar que, de um modo geral, todos os tópicos foram elaborados com o intuito de serem mais informativos que instrutivos. Ou seja, levando-se em conta as limitações do pesquisador e do grupo diante do tema, evitou-se ensinar "como fazer" ou 
apresentar uma receita pronta para os alunos. Buscou-se, porém, descrever como a comunidade científica costuma agir diante da necessidade da comunicação, oral e escrita, de seus resultados. Assim, em vários momentos no texto foram utilizadas expressões como "geralmente", “costuma-se observar", “os autores costumam elaborar...". A idéia, portanto, foi tornar o aluno receptivo a outras formas de elaboração de textos científicos, muitas vezes tão eficientes quanto às formas expostas no material.

A fonte utilizada (Garamond), tamanho 13, foi selecionada por razões tais como sua simplicidade, facilitando assim a compreensão dos caracteres e por ser serifada (com traços ao final de cada letra) proporcionando idéia de continuidade, facilitando a leitura linear do texto. Para proporcionar destaque a alguns componentes do material, como títulos, subtítulos e frases ressaltando características dos exemplos, foi selecionada uma fonte não-serifada (Lucida Sans Unicode), diferenciando-os, assim, do corpo do texto. Ademais, com a finalidade de dar maior destaque visual, foi utilizada uma fonte decorativa (LittleLordFontleroy) nas iniciais dos tópicos principais e no título do material.

Foi utilizado espaçamento simples em todo o texto, com espaços entre cada parágrafo. Este recurso foi utilizado como objetivo de agrupar as informações em cada parágrafo, condensando-os em espaços simples entre as linhas, e, ao mesmo tempo, não sobrecarregar o leitor com excesso de caracteres, separando cada parágrafo com um espaço simples entre eles.

Outro recurso aplicado para chamar atenção do leitor para algumas partes do texto, sobretudo nos exemplos, foi a utilização de setas, as quais garantiram um aspecto bastante didático ao material produzido. Além disso, o recurso Realçar (preenchimento de linhas em 
cinza $25 \%$ ) foi também bastante utilizado para dar destaque a palavras ou frases nos exemplos apresentados no material.

Por fim, foi produzido um material impresso apresentado 81 páginas formatadas em papel A4. A opção por fazê-lo impresso foi oriunda de debates entre os sujeitos da pesquisa, em reuniões nas quais questionava-se qual o melhor veículo de divulgação do material para o público a que se destina, conforme pode ser observado nas falas dos sujeitos a seguir.

$\left(\boldsymbol{A} \boldsymbol{P}_{1}\right)$ - No termo de facilidade para o aluno, eu sugeria uma página. Mas tem que ser bem explicada...

$(\boldsymbol{P Q})$ - Atualizar, não é?

$(\boldsymbol{A P})$ - Porque isso é complicado, não é, ficar mantendo a página.

(PR) - Sobre a página, eu acho que o ideal seria ter á pagina e a apostila. Porque a página, você pode modificar, mas, imagina você estando em casa e precisando de apoio e se você não tem computador? Então possibilita o acesso. É dinâmico, você pode modificar... Já apostila seria mais importante.

$(\boldsymbol{P Q})$ - Tem acesso sempre.

É possível observar, portanto, que dentre as opções relatadas estavam uma página na Internet ou um texto impresso. A opção de disponibilizar o material via web mostrou-se interessante ao suprimir custos com impressão, além de permitir atualizações de seu conteúdo. Por outro lado, seu acesso dependeria do aluno ter disponível um computador sempre que necessitassem consultá-lo. Por esse motivo, o material impresso mostrou-se a opção de escolha dos participantes da pesquisa.

\subsection{VALIDAÇÃO DO MATERIAL}

Ainda na fase da pesquisa de programação e execução de um plano de ação foi realizada a etapa de validação do material, na qual o material impresso foi entregue juntamente com um questionário (Apêndice D) para sua avaliação a outros sujeitos também relacionados à área de Química, mas não envolvidos no processo de elaboração do material. 
Assim, buscou-se promover uma análise mais precisa da receptividade do material produzido, tanto por alunos, quanto por professores da área de Química.

O questionário de avaliação do material abordou diversos aspectos referentes ao conteúdo e aparência do material. A Tabela 4 a seguir apresenta as perguntas e a distribuição das respostas fornecidas pelos sujeitos ao questionário, referentes a tais aspectos.

Tabela 4 - Distribuição percentual das respostas fornecidas pelos oito sujeitos ao questionário de avaliação do material (etapa de validação).

\begin{tabular}{|c|c|c|c|c|c|}
\hline \multirow[b]{2}{*}{ QUESTÕES } & \multicolumn{5}{|c|}{ RESPOSTAS (\%) } \\
\hline & 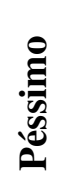 & $\stackrel{\Xi}{\Xi}$ & 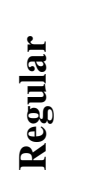 & 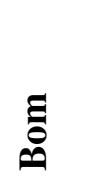 & 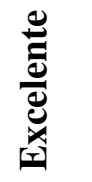 \\
\hline $\begin{array}{l}\text { 1- O título é atraente? Indica o conteúdo do } \\
\text { material? }\end{array}$ & - & - & - & 62,5 & 37,5 \\
\hline $\begin{array}{l}\text { 2- Os tópicos descritos no Sumário são } \\
\text { interessantes? São úteis no desenvolvimento } \\
\text { de trabalhos científicos? }\end{array}$ & - & - & - & $12,5-$ & 87,5 \\
\hline $\begin{array}{l}\text { 3- A seqüência dos tópicos é adequada? Facilita a } \\
\text { leitura do material? }\end{array}$ & - & - & - & 50,0 & 50,0 \\
\hline $\begin{array}{l}\text { 4- O conteúdo apresentado em cada tópico é } \\
\text { adequado? Relaciona-se coerentemente com o } \\
\text { título de cada tópico? }\end{array}$ & - & - & - & 37,5 & 62,5 \\
\hline $\begin{array}{l}\text { 5- As seções (sub-divisões) de cada tópico estão } \\
\text { bem organizadas? Facilitam a localização do } \\
\text { conteúdo? }\end{array}$ & - & - & - & 50,0 & 50,0 \\
\hline $\begin{array}{l}\text { 6- A linguagem utilizada no material é clara? Não } \\
\text { dificulta a compreensão dos tópicos abordados? }\end{array}$ & - & - & - & 37,5 & 62,5 \\
\hline $\begin{array}{l}\text { 7- A linguagem e os tópicos abordados são } \\
\text { apropriados a alunos do primeiro ano de } \\
\text { graduação? }\end{array}$ & - & - & 12,5 & 50,0 & 37,5 \\
\hline $\begin{array}{l}\text { 8- Os exemplos apresentados são adequados? } \\
\text { Tornam mais claras as informações descritas? }\end{array}$ & - & - & - & 62,5 & 37,5 \\
\hline $\begin{array}{l}\text { 9- Os destaques realizados nos exemplos } \\
\text { (preenchimento, sublinhado, setas) tornam sua } \\
\text { apresentação mais didática e compreensível? }\end{array}$ & - & - & - & 50,0 & 50,0 \\
\hline
\end{tabular}


10- A aparência do texto (fonte, espaçamento) é agradável e favorece sua leitura?

$-\quad-\quad 12,5 \quad 50,0 \quad 37,5$

O título do material foi bem aceito entre os sujeitos, sendo considerado bom $(62,5 \%)$ e excelente (37,5\%). A principal consideração apresentada no questionário foi em relação ao público-alvo descrito no título, pois, conforme relatado por um dos professores do ensino superior de Química, o material “servirá também para alunos de pós-graduação”. Esse aspecto também foi abordado por um dos alunos de pós-graduação, ao descrever material como sendo "útil durante toda a vida acadêmica do aluno". Além disso, foi questionado por outro professor pelo fato do título "fechar numa clientela: graduação em Química", uma vez que pode ser também direcionado a outros alunos de Ciências.

Foram fornecidos pelos sujeitos conceitos de bom ou excelente, tanto em relação aos tópicos abordados no material (12,5\% bom e $87,5 \%$ excelente) quanto em relação a sua seqüência de apresentação (50,0\% bom e 50,0\% excelente). Segundo um dos alunos de graduação do primeiro ano de Química, "a distribuição foi feita de forma direta o que ajuda na localização do leitor" ou ainda, como relatado por um dos alunos de iniciação científica "os tópicos são muito úteis, para nós estudantes, permitindo um desenvolvimento melhor de trabalhos". Estas considerações indicaram que um dos objetivos a que se propõe o material foi atingido: auxiliar os alunos no desenvolvimento de seus trabalhos científicos.

O conteúdo apresentado em cada tópico foi bem conceituado entre os sujeitos, sendo considerado bom por $37,5 \%$ e excelente por $62,5 \%$ dos sujeitos. As divisões apresentadas nos tópicos em seções também tiverem uma boa aceitação.

As questões relacionadas à linguagem também forneceram importantes informações sobre a impressão dos sujeitos tanto em relação à sua clareza (37,5\% bom e 62,5\% excelente) quanto em relação a sua adequação a alunos de primeiro ano de graduação (12,5\% regular, 
$50,0 \%$ bom e $37,5 \%$ excelente). Segundo um dos alunos de iniciação científica, o material "apresenta um linguagem gostosa, atrativa e bem didática, de fácil entendimento". Ao ser questionado se a linguagem e os tópicos abordados são apropriados a alunos de primeiro ano de graduação, um dos professores do ensino superior de Química considerou que, embora o texto possa ser lido por alunos do primeiro ano, "é muita informação para um aluno que está iniciando a graduação e ainda não entrou em um grupo de pesquisa".

A apresentação de exemplos no material, uma estratégia adotada para tornar mais claras as informações descritas nos tópicos, também foi analisadas pelos sujeitos no questionário de avaliação. Nesse aspecto, os sujeitos consideraram a utilização dos exemplos bom $(62,5 \%)$ ou excelente $(37,5 \%)$. Segundo um dos alunos de graduação do primeiro ano de Química “os exemplos ilustram muito bem o conteúdo". Sua importância foi ainda enfatizada por um dos professores do ensino superior de Química, como relatado com as seguintes palavras: "sem os exemplos, penso que iria dificultar a compreensão".

Ainda com relação às estratégias utilizadas no material para tornar as informações mais compreensíveis aos alunos, foram aplicados nos exemplos alguns destaques, tais como preenchimento, sublinhado e setas. Tais estratégias também foram abordadas no questionário de avaliação, cujas impressões relatadas pelos sujeitos em suas respostas foram boas $(50,0 \%)$ ou excelentes $(50,0 \%)$. Segundo um dos alunos de iniciação científica "as setas são os melhores destaques, pois direcionam o aluno a prestar atenção em algo específico".

A aparência geral do texto, fontes e espaçamento utilizados, também foram avaliados pelos sujeitos, os quais consideraram tais aspectos do material regular $(12,5 \%)$, bom $(50 \%)$ ou excelente $(37,5 \%)$. Nesse aspecto, um dos alunos de iniciação científica teceu o seguinte comentário: "O fato das letras não serem tão pequenas, existirem espaçamento entre um parágrafo e outro, letras maiores nos subtítulos, ...tornaram a leitura mais agradável”. Por outro lado, um dos alunos de iniciação científica manifestou preferir "um espaçamento um 
pouco maior entre as frases, pois facilita mais a leitura". Tais considerações nos permitem concluir que, apesar não agradar completamente todos os sujeitos, o material de um modo geral causou uma boa impressão, sendo, portanto, bem aceito entre os avaliadores. 


\section{Considerações}

Finals

A capacidade de comunicação e expressão em linguagem científica vem sendo descrita em revistas especializadas em Educação em Ciências como uma habilidade importante para a formação dos graduandos de Ciências. Na área de Química, tais habilidades também têm sido apontadas como essenciais tanto para a vida acadêmica, quanto para a vida profissional. Apesar da reconhecida dificuldade encontrada pelos alunos na expressão de seus conhecimentos, segundo a pesquisa realizada na literatura não existem relatos sobre a publicação de materiais didáticos sobre comunicação científica, específicos para a área de Química no Brasil, sobretudo com conteúdos direcionados a estudantes de graduação. Desta forma, é possível vislumbrar a importância da elaboração deste material sobre comunicação científica, o qual será capaz de auxiliar no desenvolvimento das habilidades de expressão oral e escrita em linguagem científica.

O conteúdo do material foi elaborado tendo como público-alvo alunos de Química, o que pode ser percebido na riqueza de exemplos extraídos de congressos e revistas da área de 
Química. No entanto, consideramos que as informações expostas no material também podem ser aproveitadas por alunos de outras áreas das Ciências Naturais, como Física e Biologia, por exemplo.

A elaboração do referido material, baseada nos fundamentos da pesquisa participativa (LE BOTERF, 1999), mostrou-se um caminho bastante enriquecedor, uma vez que permitiu a inclusão de idéias e críticas de alunos e professores no seu processo de elaboração, de modo a torná-lo mais próximo das necessidades do público-alvo. A etapa de validação demonstrou com mais intensidade a boa aceitação do material tanto por alunos quanto por professores.

Assim, foi possível perceber no decorrer da pesquisa as constantes transformações ocorridas durante a elaboração do material, tais como o título do material, os títulos dos tópicos e sua seqüência de apresentação. A inclusão de novos conteúdos e abordagens, em resposta às sugestões do grupo, também esteve presente neste modelo de construção participativa do conhecimento, como por exemplo, as abordagens de questões relacionadas ao marketing e ética em comunicação científica. Pode-se citar ainda outras contribuições do grupo consideradas importantes na elaboração do material: a inclusão de exemplos extraídos de revistas da área de Química para ilustrar as informações apresentadas no material; a abordagem de características da linguagem científica, como clareza, precisão, continuidade, no contexto da área de Química; a inclusão de uma seção sobre os diversos tempos verbais em documentos científicos. Portanto, a elaboração participativa do referido material refletiu-se em vários aspectos do texto, tanto no conteúdo quanto na sua forma de apresentação.

Ao transmitir seus conhecimentos no decorrer das reuniões, todos os sujeitos contribuíram para a elaboração do material didático, mas também se beneficiaram com a aquisição de novos conhecimentos compartilhados pelo grupo. Assim, a pesquisa participativa demonstrou ser um importante instrumento metodológico, na qual a produção do 
conhecimento manifesta-se em ação reflexiva - pelos sujeitos e para os sujeitos. Essa característica reflexiva da pesquisa participante pode ser observada em outros estudos presentes na literatura, na qual esta metodologia foi aplicada. Durante a elaboração de um material didático de Educação em Saúde, através da ação conjunta de pesquisadores, enfermeiras e mães de bebês prematuros, Fonseca (2002) descreve, com as palavras a seguir, tais aspectos da pesquisa participativa também presente em seu trabalho.

Essa metodologia, apesar de relativamente nova e pouco explorada na confecção de material didático, mostrou-se adequada, de fácil compreensão e condução para o alcance do objetivo proposto. Na dinâmica, os participantes são atores ativos mas que também se beneficiam do processo através da aquisição de conhecimento.

(FONSECA, 2002, p.125)

O percurso metodológico seguido neste trabalho permitiu, além da elaboração do próprio material, o conhecimento das diferentes visões dos sujeitos da pesquisa sobre vários aspectos relacionados à comunicação científica. Os alunos de graduação vêem a importância da comunicação científica sobretudo para suas atividades acadêmicas, porém os alunos de pós-graduação e o professor já visualizam sua importância para a vida profissional. Ficou evidenciado também que as concepções dos sujeitos sobre o relatório de laboratório também é bastante divergente: os alunos de graduação questionaram o fato de no início do curso preencherem fichas nas aulas de laboratório ao invés de escreverem um relatório completo; os alunos de pós-graduação relataram que os relatórios, em geral, são quase cópias de outros já elaborados por "veteranos" do laboratório; e o professor questiona se o modelo de relatório que passa aos alunos é o mais adequado, pois não foi preparado para ensiná-los como preparar um relatório. Outro ponto também polêmico foi em relação às apresentações orais e a escrita científica: os alunos de graduação descrevem ser a exposição em público sua maior dificuldade, embora sintam necessidade de exercitar mais esta habilidade; alunos de pósgraduação e professor descrevem, ao contrário dos alunos de graduação, a escrita como sendo mais difícil que a apresentação oral, pois a escrita requer precisão e na exposição oral é 
possível explicar novamente pontos que não ficaram claros. Em relação a marketing e ética em comunicação todos reconhecem a importância da publicação para o pesquisador, mas questionam a forma como a comunicação científica vem sendo realizada: a busca por quantidade e nem sempre por qualidade. E por fim os sujeitos, sobretudo o professor e os alunos de pós-graduação, discutiram a evolução da ciência e sua especialização, onde reconhecem suas limitações de estudo e conhecimento diante de um universo de informações lançadas continuamente na literatura científica.

Tais concepções de alunos e professor foram obtidas no contexto das discussões em grupo sobre o desenvolvimento do material didático sobre comunicação científica e serviram também de subsídio para sua elaboração. As experiências e relatos dos sujeitos de pesquisa, além de fomentarem novas discussões sobre como a comunicação científica tem se apresentado no cenário atual, podem servir de subsídio para a elaboração de propostas de ensino direcionadas ao desenvolvimento de habilidades de comunicação científica. 
ABRAHAMSOHN, P. Redação científica. Rio de Janeiro: Guanabara Koogan, 2004. 267p.

ALMEIDA, C. A.; LIOTTA, L. Organic chemistry of the cell: an interdisciplinary approach to learning with a focus on reading, analyzing, and critiquing primary literature. Journal of Chemical Education, v. 82, n. 12, p. 1794-1799, 2005.

ANDRADE, J.B. A avaliação por pares. Química Nova, v. 28, n. 6, p. 939, 2005.

ARAÚJO, C. As marcas da violência na construção da identidade de jovens da periferia. Educação e Pesquisa, v. 27, n. 1, p. 141-160, 2001.

BENÍTEZ-BRIBIESCA, L.; MODIANO-ESQUENAZI, M. Ethics of science publication after stem cell scandal. Archives of Medical Research, v. 37, p. 423-424, 2006.

BORDA, O.F. Aspectos teóricos da pesquisa participante. In: BRANDÃO, C.R. Pesquisa Participante. São Paulo: Brasiliense, 1999. 211p.

BOWYER, W.J.; KAYDOS, J.A. A novel format for seminar during the senior year of the college chemistry curriculum. Journal of Chemical Education, v. 74, n. 2, p. 184-185, 1997. 
BRANDÃO, C.R. Repensando a pesquisa participante. São Paulo: Brasiliense, 1999. 252p.

BRESSETTE, A.R.; BRETON, G.W. Using writing to enhance the undergraduate research experience. Journal of Chemical Education, v. 78, n. 12, p. 1626-1627, 2001.

BUCHWEITZ, B. Aprendizagem significativa: idéias de estudantes concluintes de curso superior. Investigações em Ensino de Ciências, v. 6, n. 2, 2001. Disponível em:

<http://www.if.ufrgs.br/public/ensino/vol6/n2/v6_n2_a2.html>. Acesso em: 08 mar 2006.

BUTZ, A. M.; KOHR, L.; JONES, D. Developing a successful poster presentation. Journal of Pediactric Health Care, v. 18, n. 1, p. 45-48, 2004.

CAPES. Critérios para avaliação dos programas de pós-graduação da área de Química 2001/2003. Disponível em: <http://www.capes.gov.br/capes/portal/conteudo/QUIMICA.pdf>. Acesso em: 9 jun 2006.

CHAMLIAN, H. C. Docência na universidade: professores inovadores na USP. Cadernos de Pesquisa, n. 18, p. 41-64, 2003.

COMEFORD, L. Writing assignments in Physical Chemistry. Journal of Chemical Education, v. 74, n. 4, p. 392, 1997.

COOKE, R. C. Undergraduate online chemistry literature searching: an open-ended, course segment approach. Journal of Chemical Education, v. 71, n. 10, p. 867-871, 1994.

DEMO, P. Elementos metodológicos da pesquisa participante. In: BRANDÃO, C.R. (Org.) Repensando a pesquisa participante. São Paulo: Brasiliense, 1999. 252p.

DODD, J. S. The ACS Style Guide: a manual for authors and editors. 2.ed. Oxford: University Press, 1997. 472p.

DOUGHERTY, R.C. Grade/study-performance contracts, enhanced, communication, cooperative learning, and student performance in undergraduate organic chemistry. Journal of Chemical Education, v. 74, n. 6. p. 722-726, 1997.

DOUGHERTY, R.C.; BOWEN, C.W.; BERGER, T.; REES, W.; MELLON, E.K.; PULLIAM. Cooperative learning enhanced communication. Journal of Chemical Education, v. 72, n. 9, p. 793-797, 1995. 
DUNSTAN, M.; BASSINGER, P. An innovative model: undergraduate poster sessions by health profession majors as a method for communicating chemistry in context. Journal of Chemical Education, v. 74, n. 9, p. 1067-1069, 1997.

FONSECA, L. M. M. Cuidados ao bebê prematuro: cartilha educativa para orientação materna. Ribeirão Preto, 2002. 151f. Dissertação (Mestrado) - Escola de Enfermagem de Ribeirão Preto, Universidade de São Paulo, Ribeirão Preto, 2002.

GAMA, A. A. S.; FERREIRA, V. F. A pós-graduação em química no Brasil melhor seus indicadores de qualidade. Química Nova, v. 27, n. 5, p. 687, 2004.

GARSON, L.R. Communication original research in chemistry and related sciences. Accounts of Chemistry Research, v. 37, n. 3, p. 141-148, 2004.

GILPIN, A. A.; PATCHET-GOLUBEV, P. A guide to writing in sciences. Toronto: University of Toronto Press, 1969. 109p.

GRACE, D.M.; GILSDORF, J.W. Classroom strategies for improving students oral communication skills. Journal of Accounting Education, v. 22, p. 165-172, 2004.

HERMANN, C.K.F. Teaching qualitative organic chemistry as a writing-intensive class. Journal of Chemical Education, v. 71, n. 10, p. 861-862, 1994.

HERMES-LIMA, M. Publicar e perecer? Ciência Hoje, v. 36, n. 212, p. 76-77, 2005.

HUNTER, A.D. A capstone writing experience in polymer chemistry: writing a proposal for an instrument purchase. Journal of Chemical Education, v. 75, n. 11, p. 1424, 1998.

JACS FACTS. Disponível em: <http://pubs.acs.org/journals/jacsat/promo/facts.pdf> Acesso em: 10 fev 2006.

KIRMS, L.M. Students as letter writers: how letters inform instructors. Journal of Chemical Education, v. 81, n. 7, p. 982-984, 2004.

KOVAC, J.; SHEERWOOD, D.W. Writing in chemistry: an effective learning tool. Journal of Chemical Education, v. 76, n. 10, p. 1399-1403, 1999. 
LATOUR, B.; WOOLGAR, S. A vida de laboratório. Rio de Janeiro: Editora Relume Dumará, 1997. 310p.

LE BOTERF, G. Pesquisa participante: propostas e reflexões metodológicas. In BRANDÃO, C.R. (Org.) Repensando a pesquisa participante. São Paulo: Brasiliense, 1999. 252p.

LEMOS, A. A. B. Publicar e perecer. Ciência da Informação, v. 34, n. 2, p. 7-8, 2005.

LUZ JÚNIOR, G. E.; SOUSA, S. A.; MOITA, G. C; MOITA NETO, J. M. Química geral experimental: uma nova abordagem didática. Química Nova, v. 27, n. 1, p. 164-168, 2004.

MABROUK, P.A. Research Skills \& Ethics - A graduate course empowering graduate students for productive research careers in graduate school and beyond. Journal of Chemical Education, v. 78, n. 12, p. 1628-1631, 2001.

McGOWAN, C.; SENDALL, P. Using the World Wide Web to enhance writing assignments in introductory chemistry courses. Journal of Chemical Education, v. 74, n. 4, p. 391. 1997.

McMILLAN, V. E. Writing papers in the biological sciences. 2.ed. Boston: Bedford Books, 1997. 199p.

MEADOWS, A. J. A comunicação científica. Brasília: Briquet de Lemos Livros, 1999. p.263.

MELlO, D. A.; ROUQUAYROL, M. Z.; ARAÚJO, D.; AMADEI, M.; SOUZA, J.; BENTO, L. F.; GONDIN, J.; NASCIMENTO, J. Promoção à saúde e educação: diagnóstico de saneamento através da pesquisa participante articulada à educação popular (Distrito São João dos Queiroz, Quixadá, Ceará, Brasil). Caderno de Saúde Pública, v. 14, n. 3, p. 583-595, 1998.

MENGA, L.; ANDRÉ, M. E. D. A. Pesquisa em educação: abordagens qualitativas. São Paulo: EPU, 1986. 99p.

MEYER. G.M. Scientific communication for chemistry majors: a new course. Journal of Chemical Education, v. 80, n. 10, p. 1174-1177, 2003.

MILL, P.A.; SWEENEY, W.V.; DeMEO, S.; MARINO, R.; CLARKSON, S. Using poster sessions as an alternative to written examinations - the poster exam. Journal of Chemical Education, v. 77, n. 9, p. 1158-1161, 2000. 
MOURA, M. L. S.; FERREIRA, M. C.; PAINE, P. A. Manual para elaboração de projetos de pesquisa. Rio de Janeiro: EdUERJ, 1998. 134p.

NELSON, S. Manual para redação de teses, projetos de pesquisa e artigos científicos. 2.ed. Rio de Janeiro: Guanabara Koogan, 2001. 150p.

NILSSON, M.R. Student taught review sessions: fostering communication skills and reinforcing concepts. Journal of Chemical Education, v. 78, n. 5, p. 628, 2001.

OLIVEIRA FILHO, R. S.; HOCHMAN, B.; NAHAS, F. X.; FERREIRA, L. M. Fomento à publicação científica e proteção do conhecimento científico. Acta Cirúrgica Brasileira, v. 20, p. 35-39, 2005. Suplemento 2.

OLIVEIRA, J.R.S.; QUEIROZ, S.L. O desenvolvimento de habilidades de comunicação científica em disciplinas de cursos de graduação em química. In: ENCONTRO NACIONAL DE PESQUISA EM ENSINO DE CIÊNCIAS, 5., 2005, Bauru. Anais... Bauru: Associação Brasileira de Pesquisa em Educação em Ciências, 2005. Disponível em: $<$ http://www.fc.unesp.br/abrapec/venpec/atas/artigos/1/pdf/p83.pdf $>$. Acesso em: 02 mai 2006.

ORDMAN, A.B. A course of practical skills for undergraduate science majors. Journal of Chemical Education, v. 73, n. 8, p. 753-755, 1996.

PACKER, A. L. ; BIOJONE, M. R.; ANTONIO, I.; TAKENAKA, R. M.; GARCÍA, A. P.; SILVA, A. C.; MURASAKI, R. T.; MYLEK, C.; REIS, O. C.; DELBUCIO, H. C. R. F. SciELO: uma metodologia para publicação eletrônica. Ciência da Informação, v. 27, n. 2, p. 109-121, 1998.

PAULSON, D. R. Writing for chemistry: satisfying the CDU Upper-Division writing requirement. Journal of Chemical Education, v. 78, n. 8, p. 1047-1049, 2001.

PESSANHA, C. Critérios editoriais de avaliação científica: notas para discussão. Ciência da Informação, v. 27, n. 2, p. 226-229. 1998.

PETROiAnU, A. Autoria de um Trabalho Científico. Revista da Associação Médica Brasileira, v. 48, n. 1, p. 60-65, 2002. 
PINTO, A.C.; ANDRADE, J.B. Fator de impacto de revistas científicas: qual o significado deste parâmetro? Química Nova, v. 22, n. 3, p. 448-453, 1999.

QUEIROZ, S.L. A linguagem escrita nos cursos de química. Química Nova, v. 24, n. 1, p.143-146, 2001.

RODE, S. M.; CAVALCANTI, B. N. Ética em autoria de trabalhos científicos. Pesquisa Odontológica Brasileira, v. 17, p. 65-66, 2003. Suplemento 1.

ROSENFELDT, F. L.; DOWLING, J. T.; PEPE, S.; FULLERTON, M. J. How to write a paper for publication. Heart, Lung and Circulation, v. 9, p. 82-87, 2000.

ROSSENSTEIN, I. J. A literature exercise using Scifinder Scholar for the sophomore-level organic chemistry course. Journal of Chemical Education, v. 82, n. 4, p. 652-654, 2005.

ROSSI, F. M. Writing in an advanced undergraduate chemistry course: an assignment exploring the development of scientific ideas. Journal of Chemical Education, v. 74, n. 4, p. 395-396, 1997.

SÁ, L. P.; QUEIROZ, S. L. Argumentação no ensino superior de química: investigando uma atividade fundamentada em estudos de caso. Enseñanza de las Ciencias. Espanha, v.extra, p.1-5, 2005.

SÁ, L. P. A argumentação no ensino superior de Química: investigando uma atividade fundamentada em estudos de casos. 2006. 152f. Dissertação (Mestrado em Ciências) Instituto de Química de São Carlos, Universidade de São Paulo, São Carlos, 2006.

SAN'TANA, I. M. Educação inclusiva: concepções de professores e diretores. Psicologia em Estudo, v. 10, n. 2, p. 227-234, 2005.

SANTO, C. E.; FREIRE, I. M. “Quissamã somos nós!”: construção participativa de hipertexto. Ciência da Informação, v. 33, n. 1, p. 155-168, 2004.

SANTOS, G. R. O artigo científico no ensino superior de Química: desenvolvendo habilidades de leitura e interpretação. 2006. 122f. Dissertação (Mestrado em Ciências) Instituto de Química de São Carlos, Universidade de São Paulo, São Carlos, 2006.

SANTOS, G. R.; SÁ, L. P.; QUEIROZ, S. L. Uso de artigos científicos em uma disciplina de físico-química. Química Nova, v. , ano. no prelo. 
SCHMIDT, M.H. Using "Household Chemistry Projects" to develop research skills and to teach scientific writing. Journal of Chemical Education, v. 74, n. 4, p. 393-395, 1997.

SHIRBLEY JR., I.A.; MILAKOFSKY, L.M.; NICOTERA, C.L. Incorporating a substantial writing assignment into organic chemistry: library research, peer review, and assessment. Journal of Chemical Education, v.78, n. 1, p. 50-53, 2001.

SILVA, M. O. S. Refletindo a pesquisa participante. 2.ed. São Paulo: Cortez, 1991. 124p.

SISAK, M.E. Poster sessions as a learning technique. Journal of Chemical Education, v. 74, n. 9. p. 1065-1066, 1997.

SPECTOR, N. Manual para redação de teses, projetos de pesquisa e artigos científicos, 2.ed. Rio de Janeiro: Guanabara Koogan, 2001. 149p.

THIOLLENT, M. Metodologia da pesquisa-ação. 12.ed. São Paulo, Cortez, 2003. 107p.

TILSTRA, L. Using journal of articles to teach writing skills for laboratory reports in general chemistry. Journal of Chemical Education, v. 78, n. 6, p. 762-764, 2001.

UNIVERSIDADE DE SÃO PAULO - USP. PAE: programa de aperfeiçoamento de ensino. Disponível em: <http://www.usp.br/prpg/pt/index.htm\#topo >. Acesso em: 9 jun 2006.

VALLE, E.R.M. A pesquisa participante como metodologia de pesquisa em enfermagem. Enfoque, v. 16, n. 1, p. 20-23, 1988.

VOGT, C. A espiral da cultura científica. Comciência, n. 45, 2003. Disponível em: $<$ http://www.comciencia.br/reportagens/framereport.htm>. Acesso em: 03 mai 2006.

VOLPATO, G. L.; FREITAS, E. G. Desafios da publicação científica. Pesquisa Odontológica Brasileira, v. 17, p. 49-56, 2003. Suplemento 1.

WALNER, A.S.; LATOSI-SAWIN, E. Technical writing and communication in a seniorlevel chemistry seminar. Journal of Chemical Education, v. 76, n. 10, p. 1404-1406, 1999. 
WHELAN, R.J.; ZARE, R.N. Teaching effective communication in a writing-intensive analytical chemistry course. Journal of Chemical Education, v. 80, n. 8, p. 904-906, 2003.

WILLIAMS, E.T. C\&EN: a good resource for student papers. Journal of Chemical Education, v. 74, n. 4, p. 389-390, 1997.

WILSON, J.W. Writing to learn in a organic chemistry course. Journal of Chemical Education, v. 71, n. 12, p. 1019-1020, 1994.

ZANON, D. A. V.; ALMEIDA, M. J. P. M.; QUEIROZ, S. 1. Contribuições da leitura de um texto de Bruno Latour e Steve Woolgar sobre a vida de laboratório por graduandos em Química. In: ENCONTRO NACIONAL DE PESQUISA EM EDUCAÇÃO EM CIÊNCIAS, 5., 2005, Bauru. Anais... Bauru: Associação Brasileira de Pesquisa em Educação em Ciências. Disponível em: <http://www.fc.unesp.br/abrapec/venpec/atas/artigos/3/pdf/p361.pdf> Acesso em: 02 mai 2006. 
APÊNDICE A - Revisão bibliográfica realizada na revista Journal of Chemical Education no período de janeiro de 1994 a junho de 2006 sobre disciplinas cujas estratégias de ensino são direcionadas ao desenvolvimento de habilidades de comunicação e expressão em linguagem científica em cursos de graduação em Química.

$\underline{1994}$

COOKE, R. C. Undergraduate online chemistry literature searching: na open-ended, course segment approach. Journal of Chemical Education, v.71, n.10, p.867-871, 1994.

HERMANN, C.K.F. Teaching qualitative organic chemistry as a writing-intensive class. Journal of Chemical Education, v. 71, n.10, p. 861-862, 1994.

WILSON, J.W. Writing to learn in a organic chemistry course. Journal of Chemical Education, v. 71, n.12, p. 1019-1020, 1994.

$\underline{1995}$

DOUGHERTY, R.C.; BOWEN, C.W.; BERGER, T.; REES, W.; MELLON, E.K.; PULLIAM. Cooperative learning enhanced communication. Journal of Chemical Education, v. 72, n. 9, p. 793-797, 1995. 
$\underline{1996}$

BERKA, K.M.; BERKA, L.H. Developing student speaking skill: a project/independent study in forensic science. Journal of Chemical Education, v.73, n.10, p.931-933, 1996.

ORDMAN, A.B. A course of practical skills for undergraduate science majors. Journal of Chemical Education, v.73, n.8, p.753, 1996.

$\underline{1997}$

BOWYER, W.J.; KAYDOS, J.A. A novel format for seminar during the senior year of the college chemistry curriculum. Journal of Chemical Education, v.74, n.2, p.184-185, 1997.

COMEFORD, L. Writing assignments in physical chemistry. Journal of Chemical Education, v. 74, n. 4, p.392, 1997.

DOUGHERTY, R.C. Grade/study-performance contracts, enhanced, communication, cooperative learning, and student performance in undergraduate organic chemistry. Journal of Chemical Education, v. 74, n. 6. p.722-726, 1997.

DUNSTAN, M.; BASSINGER, P. An innovative model: undergraduate poster sessions by health profession majors as a method for communicating chemistry in context. Journal of Chemical Education., v. 74, n. 9, p.1067-1069, 1997.

McGOWAN, C.; SENDALL, P. Using the world wide web to enhance writing assignments in introductory chemistry courses. Journal of Chemical Education, v. 74, n .4, p.391. 1997.

ROSSI, F.M. Writing in an advanced undergraduate chemistry course: an assignment exploring the development of scientific Ideas. Journal of Chemical Education, v. 74, n.4, p. 395-396, 1997.

SCHMIDT, M.H. Using "Household Chemistry Projects" to develop research skills and to teach scientific writing. Journal of Chemical Education, v. 74, n. 4, p. 393-395, 1997.

SISAK, M.E. Poster sessions as a learning technique. Journal of Chemical Education, v.74, n. 9. p.1065-1066, 1997. 
WILLIAMS, E.T. C\&EN: a good resource for student papers. Journal of Chemical Education, v.74, n.4, p.389-390, 1997.

$\underline{1998}$

HUNTER, A.D. A capstone writing experience in polymer chemistry: writing a proposal for an instrument purchase. Journal of Chemical Education, v. 75, n. 11, p.1424, 1998.

$\underline{1999}$

KOVAC, J.; SHEERWOOD, D.W. Writing in chemistry: an effective learning tool. Journal of Chemical Education, v. 76, n.10, p.1399-1403, 1999.

WALNER, A.S.; LATOSI-SAWIN, E. Technical writing and communication in a seniorlevel chemistry seminar. Journal of Chemical Education, v.76, n.10, p.1404-1406, 1999.

$\underline{2000}$

MILL, P.A.; SWEENEY, W.V.; DeMEO, S.; MARINO, R.; CLARKSON, S. Using poster sessions as an alternative to written examinations - the poster exam. Journal of Chemical Education, v.77, n. 9, p. 1158-1161, 2000.

$\underline{2001}$

BRESSETTE, A.R.; BRETON, G.W. Using writing to enhance the undergraduate research experience. Journal of Chemical Education, v. 78, n. 12, p. 1626-1627, 2001.

MABROUK, P.A. Research Skills \& Ethics - A graduate course empowering graduate students for productive research careers in graduate school and beyond. Journal of Chemical Education, v.78, n. 12, p.1628-1631, 2001.

NILSSON, M.R. Student taught review sessions: fostering communication skills and reinforcing concepts. Journal of Chemical Education, v. 78, n. 5, p.628, 2001.

PAULSON, D. R. Writing for chemistry: satisfying the CDU Upper-Division writing requirement. Journal of Chemical Education, v. 78, n. 8, p.1047-1049, 2001.

SHIRBLEY JR., I.A.; MILAKOFSKY, L.M.; NICOTERA, C.L. Incorporating a substantial writing assignment into organic chemistry: library research, peer review, and assessment. Journal of Chemical Education, v.78, n. 1, p. 50-53, 2001. 
TILSTRA, L. Using journal of articles to teach writing skills for laboratory reports in general chemistry. Journal of Chemical Education., v.78, n. 6, p.762-764, 2001.

$\underline{2002}$

SCHILDCROUT, S.M. Learning chemistry research outside the laboratory: novel graduate and undergraduate courses in research methodology. Journal of Chemical Education, v. 79, n.11, p. 1340-1343, 2002.

$\underline{2003}$

MEYER. G.M. Scientific communication for chemistry majors: a new course. Journal of Chemical Education, v. 80, n. 10, p. 1174-1177, 2003.

WHELAN, R.J.; ZARE, R.N. Teaching effective communication in a writing-intensive analytical chemistry course. Journal of Chemical Education, v. 80, n. 8, p. 904-906, 2003.

$\underline{2004}$

KIRMS, L.M. Students as letter writers: how letters inform instructors. Journal of Chemical Education, v. 81, n. 7, p.982-984, 2004.

$\underline{2005}$

ALMEIDA, C. A.; LIOTTA, L. Organic Chemistry of the Cell: an interdisciplinary approach to learning with a focus on reading, analyzing, and critiquing primary literature. Journal of Chemical Education, v.82, n.12, p.1794-1799, 2005.

ROSSENSTEIN, I. J. A literature exercise using Scifinder Scholar for the sophomore-level organic chemistry course. Journal of Chemical Education, v.82, n.4, p.652-654, 2005. 


\section{APÊNDICE B - Termo de Consentimento entregue aos sujeitos de pesquisa}

\section{Termo de Consentimento}

Nome da Pesquisa: Pesquisa Participativa na Elaboração de um Material Didático de Comunicação em Linguagem Científica para Estudantes de Graduação em Química.

Pesquisadores responsáveis: Profa. Dra. Salete Linhares Queiroz (orientadora), Jane Raquel Silva de Oliveira (aluna de mestrado).

Informações sobre a pesquisa: Nesta pesquisa queremos que você participe do desenvolvimento de um material educativo sobre comunicação e expressão em linguagem científica para estudantes de graduação em Química. Com esse material esperamos que os estudantes aprendam, desde o início do curso, a desenvolver trabalhos nos quais são requeridas habilidades de comunicação em linguagem científica.

Assim, convidamos você, ( ) aluno de graduação em Química no primeiro ano/ ( ) aluno de graduação em Química no último ano/ ( ) aluno de pós-graduação/ （ ) docente do ensino de Química, a participar deste estudo. Assumimos o compromisso de manter sigilo quanto a sua identidade, como também garantimos que o desenvolvimento da pesquisa foi planejado de forma a não produzir riscos ou desconforto para os participantes. Pedimos também autorização para gravar o que for falado durante as reuniões. No caso da aceitação, você terá o direito de retirar o seu consentimento a qualquer momento.

\footnotetext{
Profa. Dra. Salete Linhares Queiroz (orientadora)

Jane Raquel Silva de Oliveira

(aluna de mestrado)
} 
$\mathrm{Eu}$,

$\mathrm{RG}$ abaixo assinado, tendo recebido as informações acima, e ciente dos meus direitos, concordo em participar da referida pesquisa, bem como ter:

1. A garantia de receber todos esclarecimentos sobre todas as discussões antes e durante o desenvolvimento da pesquisa, podendo afastar-me a qualquer momento assim que desejar.

2. A segurança plena de que não serei identificado, mantendo o caráter oficial da informação, assim como está assegurado que a pesquisa não acarretará nenhum prejuízo individual ou coletivo.

3. A segurança de que não terei nenhum tipo de despesa material ou financeira durante o desenvolvimento da pesquisa, bem como esta pesquisa não causará nenhum tipo de risco, dano físico, ou mesmo constrangimento moral e ético.

4. A garantia de que toda e qualquer responsabilidade nas diferentes fases da pesquisa é dos pesquisadores, bem como fica assegurado que haverá ampla divulgação dos resultados finais nos meios de comunicação e nos órgão de divulgação científica em que a mesma seja aceita.

5. A garantia de que todo material resultante será usado exclusivamente para a construção da pesquisa e ficará sob guarda dos pesquisadores, podendo ser requisitado pelo participante a qualquer momento.

Tendo ciência do exposto acima, desejo participar da pesquisa.

São Calos, 19 de abril de 2005

assinatura do participante 


\section{APÊNDICE C - Roteiro para discussão dos tópicos abordados no material}

TÓPICOS PARA DISCUSSÃO (Partes do Material Didático em Linguagem Científica)

PARTE 1 - A importância da comunicação científica na vida profissional do Químico.

$\Rightarrow$ A circulação das informações no meio científico.

$\Rightarrow$ Índice de impacto.

$\Rightarrow$ Fontes de financiamento.

PARTE 2 - Localizando e utilizando a literatura em Química.

$\Rightarrow$ Fontes primárias.

$\Rightarrow$ Fontes secundárias.

$\Rightarrow$ Bases de dados mais importantes em Química.

PARTE 3 - Tipos de trabalhos escritos.

$\Rightarrow$ Projetos.

$\Rightarrow$ Relatórios (laboratório, iniciação científica).

$\Rightarrow$ Artigos científicos (trabalho original, revisão bibliográfica).

$\Rightarrow$ Artigos de divulgação.

PARTE 4 - Partes de um trabalho científico

$\Rightarrow$ Título

$\Rightarrow$ Autores

$\Rightarrow$ Resumo

$\Rightarrow$ Introdução

$\Rightarrow$ Materiais e métodos

$\Rightarrow$ Resultados e Discussão

$\Rightarrow$ Conclusão

$\Rightarrow$ Referências bibliográficas

$\Rightarrow$ Agradecimentos

PARTE 5 - Outras formas de comunicação científica.

$\Rightarrow$ Painel

$\Rightarrow$ Apresentação oral

PARTE 6 - A linguagem científica em química

$\Rightarrow$ Erros mais freqüentes (jargões, etc.)

$\Rightarrow$ Noções de estilo de linguagem

1 - Dentre os tópicos relacionados anteriormente, qual (ou quais) você considera mais importante para o desenvolvimento de habilidades de comunicação científica?

2 - O que você acha da seqüência com que os tópicos são apresentados?

3 - Ainda com relação aos mesmos tópicos, você teria alguma crítica, sugestão, acréscimo modificação...? 


\section{APÊNDICE D - Questionário aplicado na etapa de validação do material.}

\section{Questionário de Avaliação do Material}

Indique sua opinião sobre o material de acordo com os tópicos relacionados a seguir.

1- O título é atraente? Indica o conteúdo do material?

( ) Péssimo

( ) Ruim

( ) Regular

( ) Bom

( ) Excelente

COMENTÁRIOS:

2- Os tópicos descritos no Sumário são interessantes? São úteis no desenvolvimento de trabalhos científicos?

( ) Péssimo

( ) Ruim

( ) Regular

( ) Bom

( ) Excelente

COMENTÁRIOS:

3- A seqüência dos tópicos é adequada? Facilita a leitura do material?

( ) Péssimo

( ) Ruim

( ) Regular

( ) Bom

( ) Excelente

COMENTÁRIOS:

4- O conteúdo apresentado em cada tópico é adequado? Relaciona-se coerentemente com o título de cada tópico?

( ) Péssimo

( ) Ruim

( ) Regular

( ) Bom

( ) Excelente

COMENTÁRIOS: 
5- As seções (sub-divisões) de cada tópico estão bem organizadas? Facilitam a localização do conteúdo?

( ) Péssimo

( ) Ruim

( ) Regular

( ) Bom

( ) Excelente

COMENTÁRIOS:

6- A linguagem utilizada no material é clara? Não dificulta a compreensão dos tópicos abordados?

( ) Péssimo

( ) Ruim

( ) Regular

( ) Bom

( ) Excelente

COMENTÁRIOS:

7- A linguagem e os tópicos abordados são apropriados a alunos do primeiro ano de graduação?

( ) Péssimo

( ) Ruim

( ) Regular

( ) Bom

( ) Excelente

COMENTÁRIOS:

8- Os exemplos apresentados são adequados? Tornam mais claras as informações descritas nos tópicos?

( ) Péssimo

( ) Ruim

( ) Regular

( ) Bom

( ) Excelente

COMENTÁRIOS:

9- Os destaques realizados nos exemplos (preenchimento, sublinhado, setas) tornam sua apresentação mais didática e compreensível? 
( ) Péssimo

( ) Ruim

( ) Regular

( ) Bom

( ) Excelente

COMENTÁRIOS:

10- A aparência do texto (fonte, espaçamento) é agradável e favorece sua leitura?

( ) Péssimo

( ) Ruim

( ) Regular

( ) Bom

( ) Excelente

COMENTÁRIOS:

\section{Comentário geral}

\section{O avaliador:}

Sexo: ( )M ( )F

Idade: ......

Escolaridade: ( ) Aluno matriculado na disciplina de Comunicação e Expressão em Linguagem Científica I no $1^{\circ}$ semestre de 2006

( ) Aluno de iniciação científica/ Qual ano ?.......

( ) Aluno de pós-graduação (mestrado)

( ) Aluno de pós-graduação (doutorado)

( ) Professor do ensino superior/ Quantos anos como docente?......... 
APÊNDICE E - Material produzido: Comunicação e Expressão em Linguagem

Científica: um Guia para Estudantes de Graduação em Química

Universidade de São Paulo

Instituto de Química de São Carlos

Comunicação e

Expressão em

Linguagem

Científica:

um guia para estudantes

de graduação em Química 
São Carlos

2006

\section{$\sum$ ista de abreVIaturas \\ E SIGLAS}

ABNT - Associação Brasileira de Normas Técnicas

ABQ - Associação Brasileira de Química

ACS - American Chemical Society

BMIC - Brazilian Meeting of Inorganic Chemistry

CAPES - Coordenação de Aperfeiçoamento de Pessoal de Nível Superior

CBCat - Congresso Brasileiro de Catálise

CBQ - Congresso Brasileiro de Química

CNPq - Conselho Nacional de Desenvolvimento Científico e Tecnológico

FAPESP - Fundação de Amparo à Pesquisa do Estado de São Paulo

Fi - Fator de Impacto

IBGE - Instituto Brasileiro de Geografia e Estatística

ISI - Institute for Scientific Information

JCR - Journal of Citation Reports

MEC - Ministério da Educação e Cultura 
SBPC - Sociedade Brasileira para o Progresso da Ciência

SBQ - Sociedade Brasileira de Química

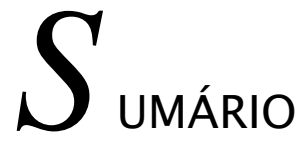

$L$ ISTA DE ABREVIATURAS E SIGLAS

$A$ Presentação

4

1 Considerações sobre a cOMUniCAÇÃo CIENTífica

5

$2 A$ lgumas fORMAS DE COMUNiCAÇÃO CIENTÍfICA 15

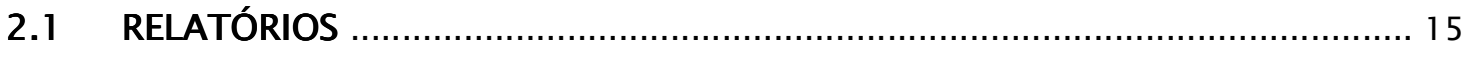

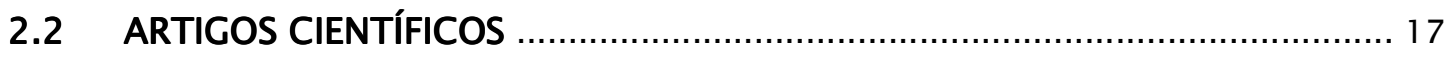

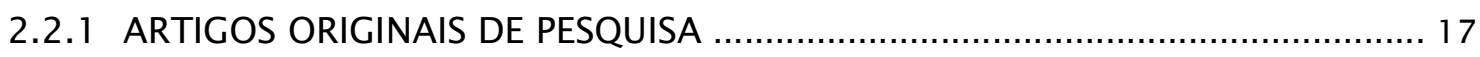

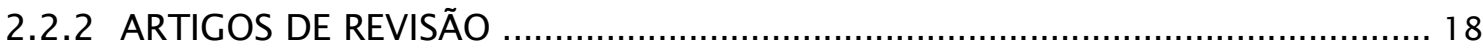

2.3. TRABALHOS APRESENTADOS EM REUNIÕES CIENTÍFICAS ..................... 20

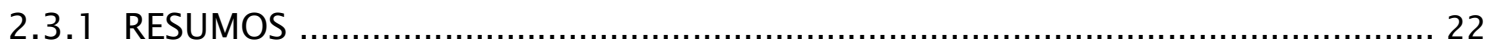

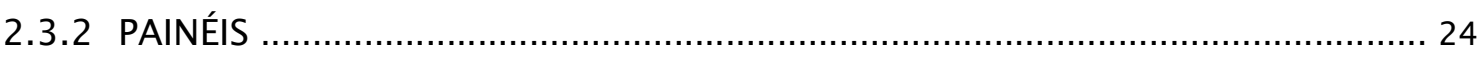

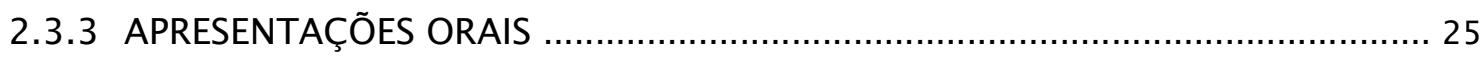

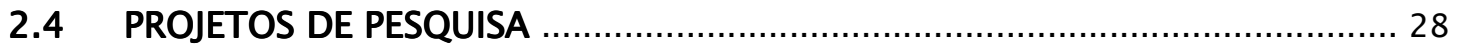

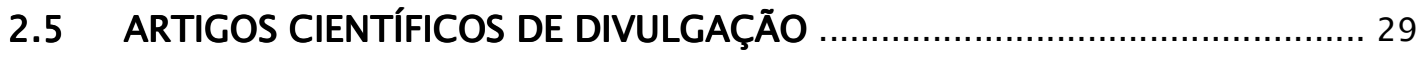

2.6 ARTIGOS RELACIONADOS À EDUCAÇÃO EM CIÊNCIA …....................... 30

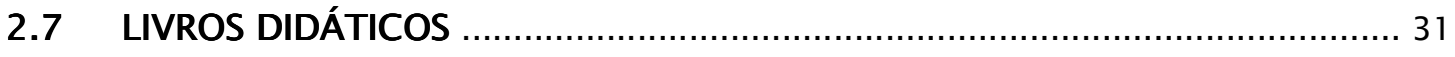

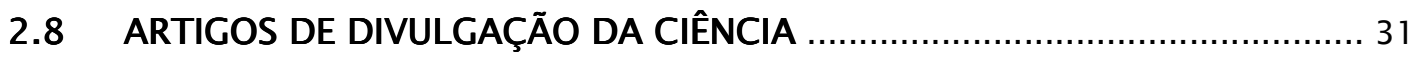


$3 P$ rincipals componente dos textos científicos

33

$3.1 \quad$ TÍTULO

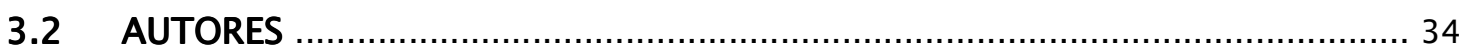

3.3 AFILIAÇÕES

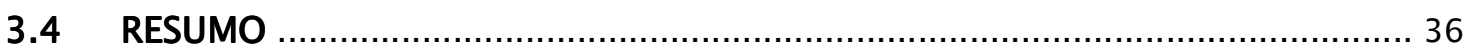

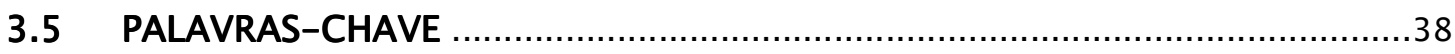

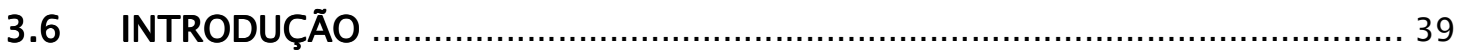

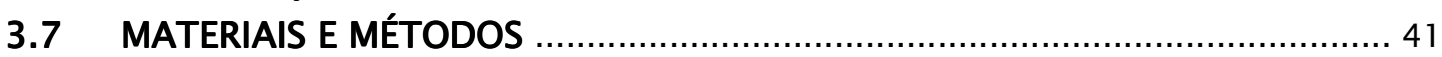

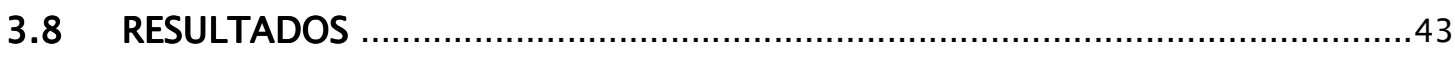

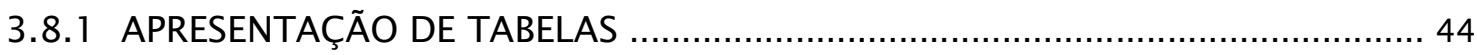

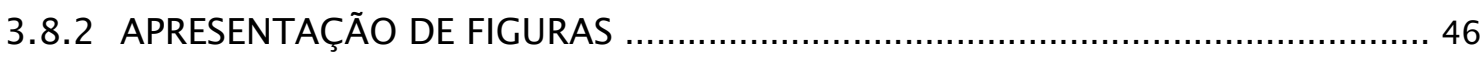

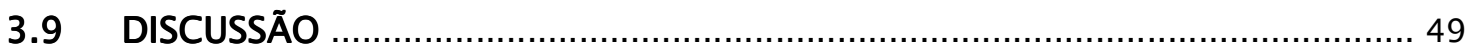

3.10 CONCLUSÕES

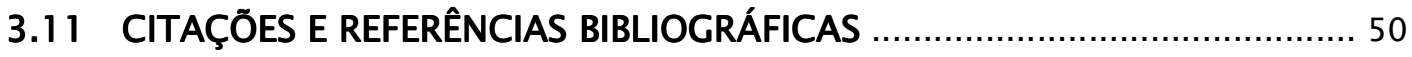

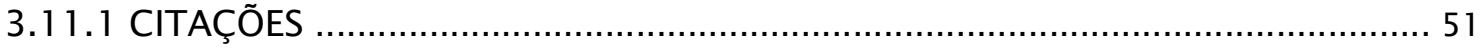

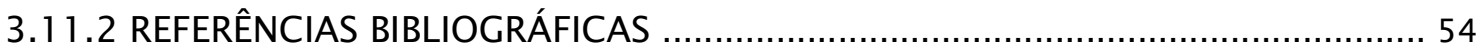

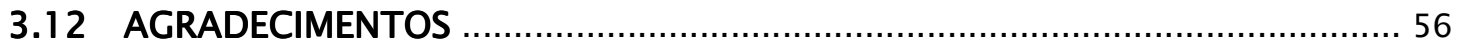

4 Localizando e utilizando a literatura em QuímiCA ...

57

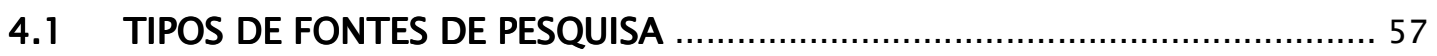

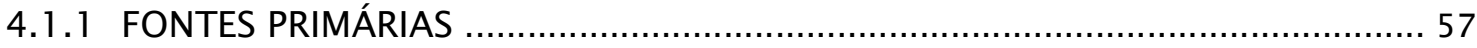

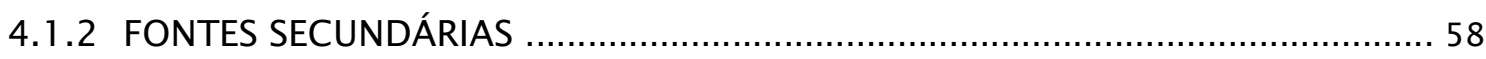

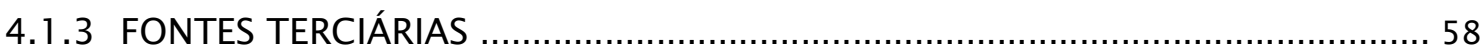

4.2 ALGUMAS BASES DE DADOS EM QUÍMICA …………............................ 59

4.2.1 BASES DE DADOS DE ACESSO PÚBLICO ……........................................... 59

4.2.2 BASES DE DADOS DE ACESSO REGULAMENTADO ........................................ 61

5 Algumas características da linguagem Científica ..... 68

5.1 ALGUMAS CARACTERÍSTICAS DA LINGUAGEM CIENTÍFICA ……..............6 68

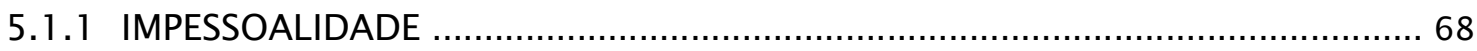

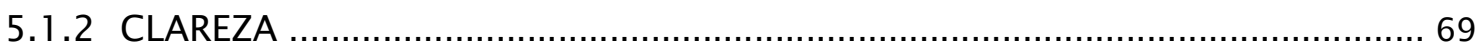

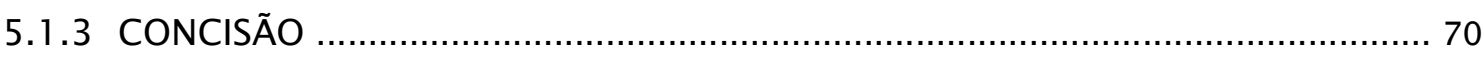

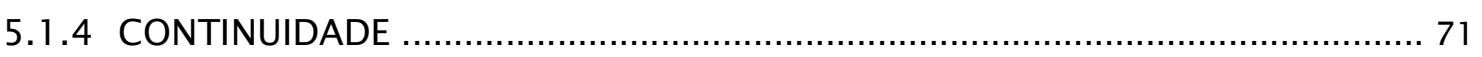

5.2 OS TEMPOS VERBAIS NOS TEXTOS CIENTÍFICOS …….............................. 74

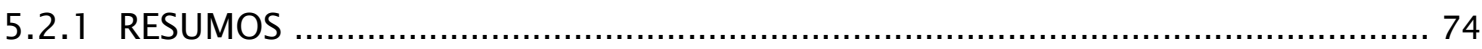




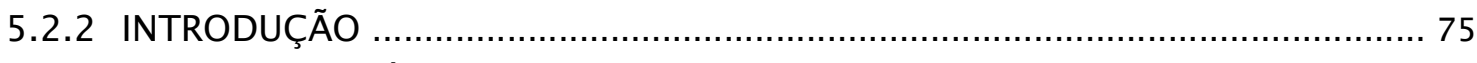

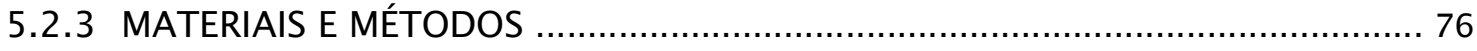

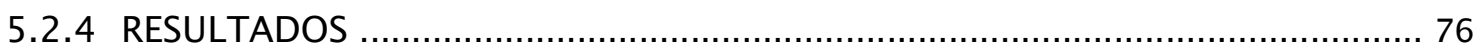

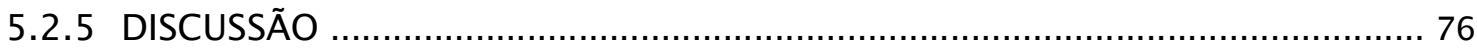

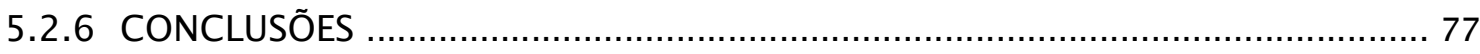

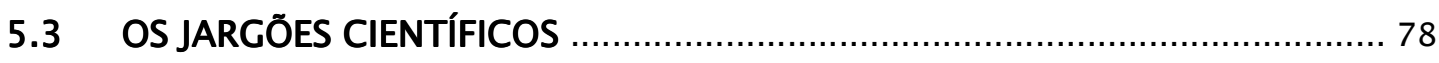

\section{B ibliografia consultada}

80

\section{$\Lambda_{\text {presentação }}$}

Poderíamos resumir este Manual em uma palavra: OBSERVAR. Esta, na realidade, é uma regra válida para tudo que pretendemos aprender na vida, inclusive para se realizar com sucesso a comunicação científica.

Uma criança aprende a falar, a caminhar e a se expressar OBSERVANDO os adultos e outras crianças. Da mesma forma, podemos aprender a desenvolver a capacidade de expressão em linguagem científica OBSERVANDO quem a faz. Leia artigos e OBSERVE como são construídos. Veja painéis em congressos e OBSERVE como eles são organizados. Assista a apresentações orais e OBSERVE como os palestrantes conduzem suas falas e estruturam suas apresentações.

A OBSERVAÇÃO, no entanto, em alguns momentos pode ser incompleta, sobretudo quando se trata da formação de pesquisadores. Desta forma, acrescentaríamos mais duas palavras que tornam o aprendizado da comunicação científica mais completo: CRITICAR e ASSIMILAR.

Além disso, o OBSERVAR é um longo caminho para o aprendizado. Acreditamos que algumas orientações podem facilitar esse percurso. Por este motivo escrevemos este guia de Comunicação e Expressão em Linguagem Científica voltado principalmente ao estudante de Química - o que não impede sua utilização por estudantes de outras áreas do conhecimento. 
Todas as informações aqui expostas não são regras fixas que devam ser rigorosamente seguidas. Use-as com bom senso e adapte-as às suas necessidades. Enfim, OBSERVE, CRITIQUE e ASSIMILE.

Jane Raquel Silva de Oliveira

Salete Linhares Queiroz 


\section{COMUNICAÇÃO CIENTÍFICA}

Desde há muito os cientistas têm se preocupado não apenas com a geração do conhecimento, mas também com a sua divulgação. Embora não se possa afirmar com exatidão quando se iniciou a comunicação científica, pode-se dizer que sua origem esteja diretamente ligada à própria produção da Ciência.

Segundo Meadows (1999), a comunicação científica na forma oral ocorreu na Grécia nos séculos V e IV a.C. Nesta época os gregos reuniam-se na Academia, em Atenas, para tratar de questões filosóficas Os gregos foram também os precursores da comunicação científica na forma escrita: os debates de Aristóteles, por exemplo, foram conservados em manuscritos e copiados repetidas vezes, influenciando a cultura árabe e a européia, sobretudo durante o Renascimento entre os séculos XIV e XVI.

A introdução da imprensa na Europa, no século XV, foi fator de grande importância para a comunicação científica, pois facilitou a difusão das informações e impulsionou as publicações científicas. A possibilidade de produção de textos impressos fez com que a produção média de livros aumentasse consideravelmente. Embora muitos desses livros não versassem especificamente sobre Ciência, o livro impresso foi também um importante veículo de transmissão dos resultados da pesquisa científica. Um dos exemplos mais marcantes dessa época foi a publicação, em 1543, do De revolutions orbitum coelestium [Das revoluções dos corpos celestes], de Copérnico - obra precursora da astronomia moderna.

Durante o século XVII e XVIII, alguns manuscritos científicos eram produzidos principalmente na forma de cartas que circulavam entre um grupo reduzido de pesquisadores que debatiam temas comuns. No entanto, a necessidade de difundir as novas idéias e descobertas a um grupo cada vez maior levou à criação, na segunda metade do século XVII, das primeiras revistas científicas. Sua origem está ligada à fundação, em 1662, da Royal Society, em Londres. Essa instituição, além de reuniões nas quais eram discutidas questões filosóficas, tinha membros no estrangeiro, responsáveis por enviar relatórios sobre os progressos científicos ocorridos nos países. Todas as correspondências eram enviadas ao secretário geral da sociedade, Henry Oldeburg, que, ao enviar cartas para outros membros, atuava como centro de difusão de novas idéias e pesquisas. Como o volume dessas cartas aumentava consideravelmente, optou-se por divulgá-las como uma publicação impressa. Assim, em março de 1665, o conselho da Royal Society determinou que o Philosophical Transactions, preparado por Oldenburg, fosse impresso na primeira segunda-feira de cada mês. O texto antes era revisto por alguns de seus membros e julgado pelo conselho, que o aprovava, ou não. Portanto, o Philosophical Transactions é 
considerado como um dos primeiros precursores dos periódicos da área de Ciências Naturais.

O formato de apresentação dos artigos nos periódicos evoluiu gradualmente ao longo dos anos. Os títulos dos primeiros artigos, por exemplo, não ofereciam informações tão detalhadas sobre seu conteúdo como os títulos dos artigos publicados atualmente. De modo geral eles eram bem mais curtos, semelhantes aos títulos de livros atuais. Além disso, os artigos geralmente eram de um único autor e não apresentavam formato rígido como os exigidos pela maioria dos periódicos modernos. Outras características da evolução do formato de apresentação dos artigos científicos podem ser observadas até mesmo em periódicos nacionais. Os artigos publicados na revista Química Nova há 30 anos, por exemplo, não apresentavam o Resumo (Abstract) em seus textos. Ademais, não havia formato uniforme (divisão em Introdução, Parte Experimental, Resultados e Discussão) estabelecido para apresentação do manuscrito. Em geral cada autor organizava seu texto de forma livre.

A evolução da comunicação científica foi ditada pelo crescimento da comunidade científica ao longo dos séculos. Esse crescimento pode ser verificado através do número de doutores formados anualmente. Os programas de pós-graduação em Química no Brasil, por exemplo, entre 1983 e 1984 formaram 75 doutores. Entre 2001 e 2003 esse número passou para 890 doutores formados. Como conseqüência deste crescimento, o número de trabalhos publicados em revistas especializadas também aumentou. Entre 1983 e 1984, na área de Química, foram publicados em revistas científicas 477 artigos, e entre 2001 e 2003, 6.565 artigos (GAMA e FERREIRA, 2004). Além disso, o número de publicações por pesquisador também cresceu. Portanto, conclui-se que o número de artigos publicados aumentou em proporção ainda maior que o crescimento da própria comunidade científica, no Brasil. Isto, de forma geral, provavelmente se verifica no exterior.

Outra conseqüência imediata do crescimento da comunidade científica foi o aumento do número de títulos de periódicos, compartimentando áreas específicas do conhecimento. Além disso, o volume de informações em cada periódico também sofreu transformações: mais fascículos de cada periódico passaram a ser publicados por ano e, em cada fascículo, o número de páginas também aumentou. $\mathrm{Na}$ área de Ciência e tecnologia podemos citar como exemplo a revista Química Nova que há 30 anos apresentava periodicidade trimestral e hoje é bimestral. Além de publicar mais volumes por ano, a mesma revista, ao longo dos anos, também aumentou o número de páginas publicadas: na década de 80 cada volume da Química Nova possuía, em média, 50 páginas e, na atual década, esse número está em cerca de 200 páginas por volume.

Este crescimento rápido do número de publicações científicas também pode ser observado em diversos periódicos internacionais. O número de artigos submetidos à publicação no Journal of the American Chemical Society, por exemplo, passou de cerca de 4.000 artigos no ano de 1994 para 8.000 em 2004 (JACS FACTS, 2006). Diante da expansão de informações publicadas nos periódicos, o número de livros que versam sobre temas científicos também cresceu significativamente. 
Uma das formas que a comunidade científica encontrou para lidar com o grande número de informações foi a especialização. Desta maneira, os cientistas foram cada vez mais aprofundando-se em uma área da Ciência e, mais adiante, em assuntos ou linhas de pesquisa dentro de uma mesma área. Ou seja, tornou-se extremamente difícil para um cientista ler e acompanhar todo o progresso ocorrido em Biologia, Física, Química e Matemática, por exemplo. Alguns cientistas passaram a ser estudiosos da área de Química. Posteriormente, outros cientistas, diante do grande número de informações na área Química, optaram, por exemplo, por direcionar mais especificamente seus estudos à Química Orgânica, ou em subáreas desta, tais como Síntese de Compostos Orgânicos, Produtos Naturais, Fármacos Orgânicos, Polímeros etc. A especialização ocorrida nas comunidades científicas refletiu-se também nos títulos dos periódicos. Surgiram, desta forma, periódicos cujos artigos tratam de assuntos cada vez mais específicos. Hoje temos periódicos como, por exemplo, o Nitric Oxide, destinado especificamente a publicar trabalhos de pesquisas relacionadas ao óxido nítrico.

Algo semelhante também pode ser observado na organização das reuniões científicas. Os pesquisadores passaram a organizar eventos cada vez mais específicos, destinados ao debate sobre uma única área da Ciência ou ainda um mesmo tema de pesquisa. Podemos citar também no Brasil, encontros mais abrangentes como a Reunião da Sociedade Brasileira para o Progresso da Ciência (SBPC), ou de uma única área da Ciência como a Reunião Anual da Sociedade Brasileira de Química (SBQ), ou ainda de subáreas como o Congresso Brasileiro de Catálise (CBCat).

Face ao grande quantidade de trabalhos científicos, surgiram, como forma de organizar e facilitar pesquisas bibliográficas, as publicações de resumos e índices. Uma das mais marcantes publicações dessa categoria para a área de Química é o Chemical Abstracts, criado em 1907 pela American Chemical Society, o qual pode ser consultado atualmente em sua tradicional versão impressa ou em sua versão eletrônica (disponível através do software SciFinder Scholar). Cabe ressaltar que à medida que aumentavam as publicações primárias (como os artigos), conseqüentemente cresciam as publicações secundárias (como livros) e as publicações terciárias (como os resumos). É de se concluir, portanto, que cada vez mais a comunidade científica deteve a árdua tarefa de localizar, em meio às mais variadas publicações, as informações que lhe interessavam.

O surgimento e expansão dos computadores contribuíram significativamente para facilitar a localização da literatura científica e aprimorar a comunicação. $O$ uso dos computadores na comunicação científica data da década de 60 , embora apenas na década de 80, devido à produção de computadores menores e com maior capacidade de armazenamento de dados e elaboração de textos e elementos gráficos, esse recurso passou a ser amplamente aceito e utilizado por vários pesquisadores (PACKER, 1998). A localização de publicações científicas foi realizada desde o início através de palavraschave. Inicialmente, era possível localizar trabalhos apenas através de palavras contidas em seus títulos. À medida que os computadores avançavam em tecnologia e capacidade de armazenamento de informações, as buscas através das palavras-chave passaram a abranger o resumo do trabalho. Atualmente, as bases de dados de pesquisa bibliográfica localizam trabalhos até mesmo através de palavras contidas em seu texto integral, bem como pelo do nome dos autores, ano de publicação, título dos periódicos etc. 
Por fim, a criação e a rápida universalização da Internet contribuíram decisivamente para integrar e divulgar as publicações científicas em todo o mundo. Surgiram as bases de dados on-line, nos quais são reunidas publicações de diversos periódicos. Aos poucos, os pesquisadores passaram a localizar cada vez mais artigos em meio eletrônico que em sua versão impressa. Um exemplo dessas bases de dados científicas é a base SCOPUS, da Editora Elsevier, que dispõe de um acervo de cerca de 14.000 periódicos, cujos artigos podem ser facilmente localizados, além de oferecer ao usuário acesso aos resumos e textos completos. Outro recurso disponível através da Internet é a submissão de trabalhos à publicação via on-line, bem como submissão de resumos para congressos e outras reuniões científicas.

Diante da expansão da comunicação e da difusão do conhecimento, alguns autores preocuparam-se em discutir como a literatura científica é produzida e difundida, não apenas entre os pesquisadores, mas também na sociedade em geral. Em seu trabalho, intitulado A Espiral da Cultura Científica, Carlos Vogt (2003) analisa a dinâmica do processo de produção literária do conhecimento científico - ou cultura científica, como é chamada por ele - como uma espiral. Segundo esse modelo, o conhecimento científico produzido circula, através de diversos meios de comunicação, entre pesquisadores, estudantes, jornalistas e a sociedade como um todo. A Figura 1 ilustra o modelo de espiral da cultura científica sugerido por Vogt.

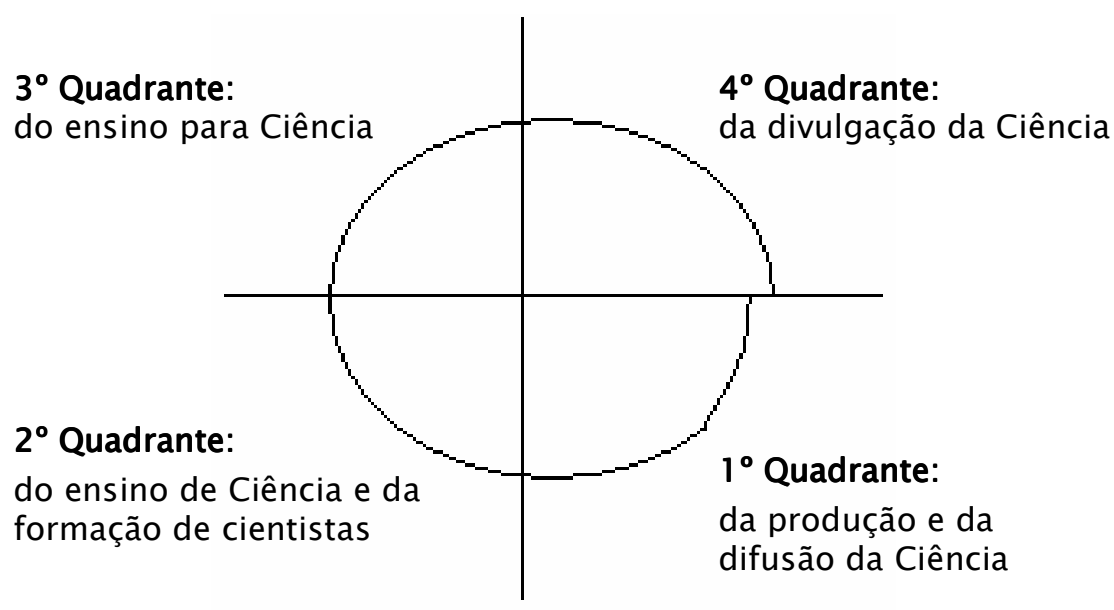

Figura 1. A espiral da cultura científica: modelo de classificação, difusão e evolução do conhecimento científico, segundo Vogt (2003).

Neste modelo, o autor inicialmente agrupa a cultura científica relacionada à produção e difusão da Ciência entre os pares, em que os cientistas produzem a literatura científica para outros cientistas $\left(1^{\circ}\right.$ quadrante). Estão envolvidas neste primeiro processo de produção do conhecimento científico as universidades, centros de pesquisa, agências de fomento à pesquisa, revistas científicas etc. Em um segundo plano (2 ${ }^{\circ}$ quadrante), 
agrupam-se os trabalhos relacionados ao ensino de Ciências e a formação de cientistas, em que os cientistas e professores, ligados às universidades e instituições de ensino médio, levam a cultura científica aos estudantes. Em um outro estágio deste caminho (3ำ quadrante), o autor agrupa as atividades de ensino para Ciência, no qual tanto cientistas, quanto professores e diretores de museus levam a cultura científica para os jovens de um modo geral. No último estágio ( $4^{\circ}$ quadrante) - mas não o final do percurso - observa-se as atividades de divulgação científica, onde jornalistas e cientistas, através de revistas de divulgação científica ou de páginas de jornais voltadas para o tema, divulgam a cultura científica à sociedade como um todo.

Um fato notório no modelo proposto por Vogt é que a cultura científica circula, mas não volta para o mesmo ponto. Por isto é chamada de espiral e não de círculo. Afinal, ao completar o percurso, o conhecimento científico já evoluiu e, portanto, aqueles que produzem, ensinam ou divulgam a cultura científica não podem partir de um mesmo ponto do conhecimento. É a evolução natural da Ciência.

Para que a Ciência possa evoluir e atingir todos os setores da sociedade, é necessário que os pesquisadores sigam o que chamamos aqui de percurso literário. Ou seja, diversos tipos de publicações científicas estão presentes no desenvolvimento de um trabalho científico. O esquema da Figura 2 demonstra como tais formas de comunicação científica estão ligadas entre si. Nele observamos que, de maneira geral, os documentos científicos que fazem parte da literatura primária (destacados nas elipses) podem ser utilizados para elaboração de documentos que compreendem a literatura secundária (destacados em retângulos) ou ainda para elaboração de novos trabalhos da própria literatura primária.

Os tipos de documentos científicos apresentados no esquema da Figura 2 sugerem, ainda, o percurso seguido por diversos cientistas. Assim, para obtenção de financiamentos para pesquisas, vários pesquisadores escrevem projetos que são encaminhados a agências que fomentam a pesquisa científica, como a FAPESP (Fundação de Amparo à Pesquisa do Estado de São Paulo), o CNPq (Conselho Nacional de Desenvolvimento Científico e Tecnológico), bancos, fundações etc. Ao elaborar um projeto de pesquisa, um cientista precisa, além de apresentar novas propostas, embasar seu estudo e sua metodologia de trabalho na literatura científica já existente. No decorrer e ao final da pesquisa, os resultados alcançados geralmente são expostos através de relatório de pesquisa, apresentados à agência financiadora ou à instituição na qual o trabalho foi desenvolvido. A elaboração de tais relatórios também se pauta no conteúdo de artigos já publicados.

Dados novos de pesquisas costumam ser apresentados em reuniões científicas na forma de painéis e resumos ou em apresentações orais. Além disso, os resultados finais de um trabalho científico, em sua maioria, são publicados em periódicos específicos no formato de artigos que reportam resultados de pesquisas (artigos originais). Outros artigos originais já publicados são utilizados para embasar a produção de novo artigo, o qual, ao ser publicado, torna-se parte da literatura científica. 
Os artigos originais também servem de base para produção de artigos de revisão, igualmente presentes em periódicos científicos. Além disso, os cientistas também produzem, a partir da literatura primária, os artigos de divulgação destinados aos pares. Trabalhos de pesquisas que possam despertar o interesse da sociedade geralmente dão origem a artigos de divulgação destinados ao público em geral, presentes em revistas de maior circulação. Por fim, os cientistas também escrevem, a partir da literatura já existente, livros direcionados a diversos níveis e a diversos públicos.

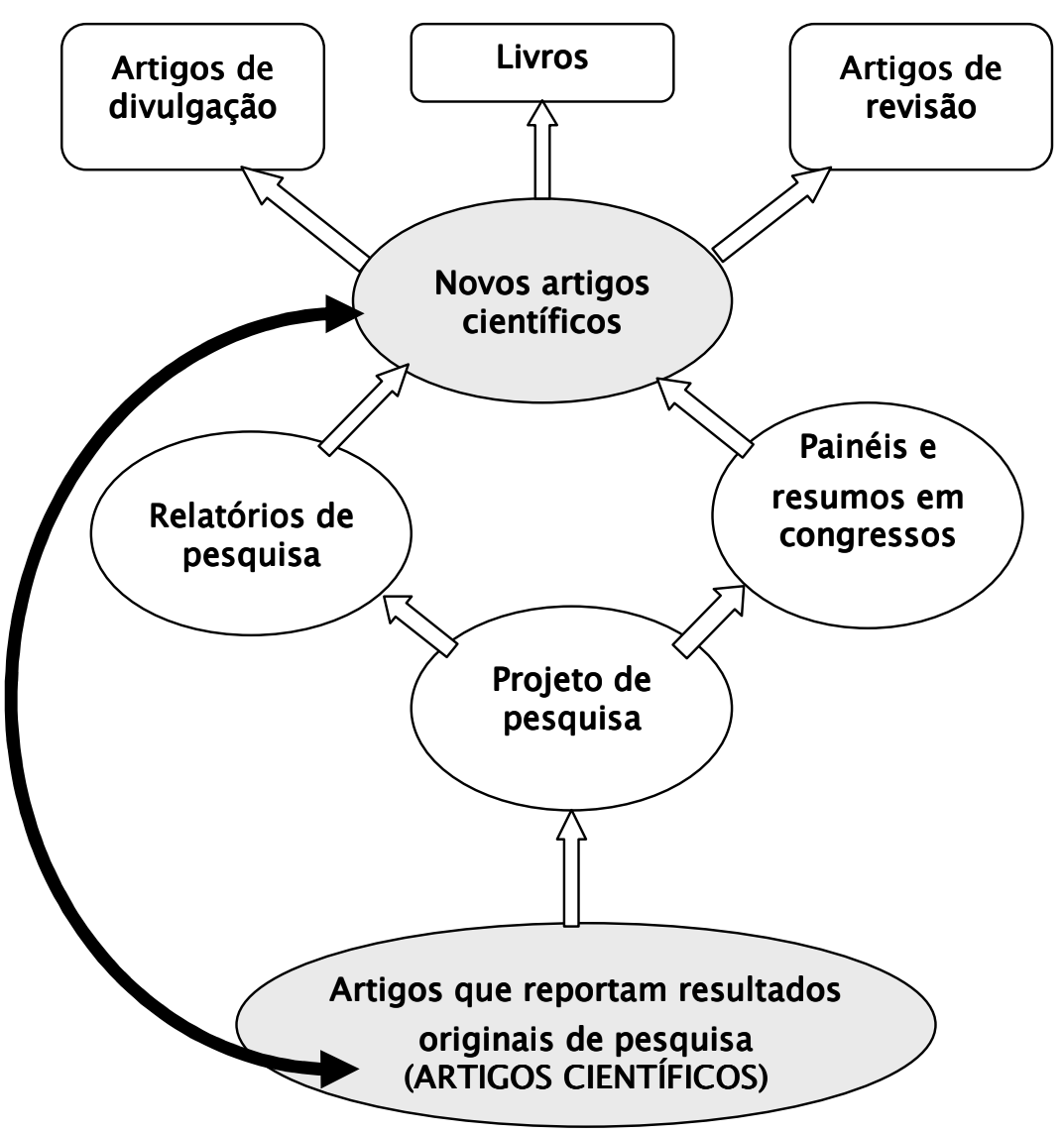

Figura 2. Relações entre os diversos tipos de publicações científicas. A literatura primária (em elipse) é utilizada como base para elaboração de outros documentos, tanto para a literatura primária quanto para a literatura secundária (em retângulo).

Com o decorrer do tempo e em face ao grande número de publicações continuamente lançadas no meio científico, surgiu a necessidade de avaliação da qualidade da literatura científica produzida. Para analisar aspectos referentes à geração, propagação e emprego das publicações científicas são utilizadas informações sobre a literatura científica mundial, produzidas anualmente, contidas em bancos de dados. Em artigo publicado na revista Química Nova, Pinto e Andrade (1999) discutem como é calculado e o que significa Fator de Impacto de revistas científicas. 
O Institute for Scientific Information (ISI) fornece o principal banco de dados utilizado para avaliar as publicações científicas. Esta avaliação é realizada através do Fator de Impacto - também chamado Índice de Impacto - dos principais periódicos científicos indexados no ISI.

O ISI publica o Science Citation Index, uma base que contém cerca de 5.330 revistas indexadas cobrindo 160 campos do conhecimento. Todas as informações são organizadas no sentido de revelar o número de citações dos artigos publicados no próprio periódico e nos demais, em determinado ano. As informações contidas no Science Citation Index são utilizadas para cálculo do fator de impacto dos principais periódicos, cujos resultados são divulgados no Journal of Citation Reports (JCR), também publicado pelo ISI.

O fator de impacto (Fi) de um periódico é calculado da seguinte maneira:

\section{$\mathbf{N}^{\circ}$ de citações dos artigos publicados em um periódico nos dois últimos anos}

$\mathrm{Fi}=$

$N^{\circ}$ de artigos publicados nesses dois anos

Exemplificando: o periódico X publicou em 2003 e 2004 um total de 89 artigos. Tais artigos, em 2005, foram citados 122 vezes. O fator de impacto deste periódico é de 122/89. Ou seja, o Fi do periódico X em 2005 é igual a 1,37. Obviamente, quando o Fi de um periódico é mais alto significa que seus artigos foram mais lidos e mais citados em outros periódicos ou no próprio periódico em que foi publicado.

$\mathrm{Na}$ área de Química, o Brasil possui duas revistas indexadas no ISI, a Química Nova e o Journal of the Brazilian Chemical Society. Esta última é a revista de maior fator de impacto entre todas as revistas latino-americanas na área de Ciências exatas (ANDRADE, 2005).

O crescimento das publicações, bem como a criação de sistemas de avaliação da literatura científica, demonstra que a comunicação científica, nos últimos anos, tem adquirido grande relevância não apenas para aqueles que fazem Ciência, mas também para as instituições que os abrigam. Uma das formas de avaliar o mérito de instituições de ensino e pesquisa é através das publicações de seus pesquisadores. Podemos citar como exemplo o sistema de avaliação dos programas de pós-graduação, criado pela CAPES (Coordenação de Aperfeiçoamento de Pessoal de Nível Superior) em 1976. Através de critérios estabelecidos para cada área, a CAPES avalia os programas de pós-graduação existentes nas instituições de ensino superior e fornece um conceito que varia de 1 a 7 . Embora este sistema avalie outros aspectos como a atividade docente, a CAPES também avalia o corpo docente "pelas publicações em periódicos internacionais de impacto elevado, participação em corpo editorial de periódicos e outras comissões acadêmicas, organização de congressos, convites para palestras, prêmios e publicações citadas internacionalmente" (CAPES, 2006).. 
Para os pesquisadores a publicação tem se tornado cada vez mais importante. Publicar pode significar possibilidades de crescimento, de reconhecimento nacional ou internacional, obtenções de bolsas de estudo, recursos financeiros para pesquisas etc. Ao submeter um projeto às agências de financiamento, por exemplo, é obrigatória a apresentação do currículo atualizado dos pesquisadores. A análise da produção científica, obviamente, é um dos critérios adotados na aprovação de recursos para projetos de pesquisa.

Um importante programa governamental de estímulo à produção científica é a Bolsa de Produtividade em Pesquisa, do CNPq. Essa bolsa é concedida a pesquisadores em função do mérito e quantidade de suas publicações, sua capacidade de formar pesquisadores e qualidade do projeto apresentado. Os valores das bolsas são variáveis de acordo com a categoria do pesquisador, a qual está relacionada à sua qualificação, experiência e capacidade de produção científica.

Desta forma, diante da grande pressão das agências de financiamento e dos órgãos governamentais para que os cientistas publiquem cada vez mais ao ano, muitos pesquisadores - às vezes por uma questão básica de sobrevivência no meio - têm publicado trabalhos pouco relevantes, incompletos ou em revistas pouco conhecidas. A busca constante por mais publicações tem se refletido na forma como a pesquisa científica, em alguns casos, é conduzida no Brasil. O trabalho apresentado na revista Ciência Hoje (HERMES-LIMA, 2005) descreve alguns dados sobre as publicações brasileiras. O texto chama atenção para seu aumento quantitativo, sem, no entanto, verificar-se o crescimento de suas citações na mesma proporção.

De fato aumentamos muito o número de publicações indexadas pelo Institute for Scientific Information (ISI) entre 1990 e 2002 passamos de 0,64\% para $1,55 \%$ da produção mundial. Mas a quantidade média de citações por trabalho só aumentou de 1,8 (no período de 1992-1996) para 2,0 (entre 1998 e 2002), de acordo com dados do CNPq. [...]

$\mathrm{Na}$ contagem de King, o Brasil publicou 1,21\% do total de artigos publicados entre 1997-2001 (dado semelhante ao do CNPq) dando-nos o $17^{\circ}$ lugar. [...]. Entretanto, os trabalhos dos brasileiros (de 1997 a 2001) receberam apenas $0,71 \%$ do total de citações mundiais, também abaixo da Austrália (2,84\%), China $(1,56 \%)$, Índia $(0,86 \%)$ e Coréia do Sul $(0,84 \%)$.

(Ciência Hoje, v.36, n.212, 76-77, 2005)

Em suma, podemos afirmar que a comunicação científica é uma das moedas mais fortes do pesquisador. Quanto mais ele faz uso dela, mais meios terá para continuar produzindo. Infelizmente, às vezes fazer Ciência implica em busca por quantidade e nem sempre por qualidade. Nesse contexto, verifica-se na comunidade científica a preocupação com a qualidade dos escritos e a veracidade das informações descritas. Para evitar que textos científicos, sem o devido mérito, sejam publicados, foram desenvolvidos mecanismos de avaliação da qualidade dos escritos, bem como estabelecidas normas de conduta ética em comunicação científica.

Um dos exemplos mais recentes e que despertou ainda mais a preocupação da comunidade científica em relação à ética na comunicação científica foi a descoberta de falsos resultados sobre clonagem de células-tronco publicada na Science, umas das revistas 
científicas mais prestigiadas no mundo (BENÍTEZ-BRIBIESCA; MODIANOESQUENAZI, 2006). O autor do artigo sobre o assunto, o coreano Woo-Suk Hwang, era considerado uma referência mundial nas pesquisas em células-tronco e seus resultados tiveram espetacular repercussão no meio científico. Este episódio demonstra que as publicações científicas podem ser alvos de conduta ética inadequada. O caso Hwang levantou também questionamentos sobre o cenário atual da Ciência, em que a ética é freqüentemente confrontada com a competitividade.

Outras condutas antiéticas, por parte dos autores, ainda podem ser observadas em publicações científicas. A mais freqüente está relacionada à definição de autoria dos trabalhos, como a inclusão de autores que não colaboraram com o trabalho ou omissão de autores que participaram do mesmo. Os autores de um trabalho devem ser, obviamente, aqueles que colaboraram efetivamente no desenvolvimento da pesquisa e da redação do artigo fornecendo, principalmente, contribuição intelectual. Também bastante conhecida na comunidade científica, o plágio é conduta antiética na qual realiza-se a cópia de textos de outros autores sem que lhes sejam atribuídas a devida autoria. O sistema de citação nos textos científicos é uma maneira simples e clara de prestigiar quem realmente foi o autor de uma idéia. Outra função igualmente importante da citação é isentar o autor de responsabilidades sobre informações eventualmente incorretas colocadas em seu trabalho, mas extraídas de textos de outros autores (PESSANHA, 1998; RODE e CAVALCANTI, 2003).

Uma das formas mais primitivas - ainda presente atualmente - de tentar avaliar a qualidade das publicações científicas é a avaliação por pares, em um sistema conhecido na comunidade científica como peer review ou referee system. O processo de avaliação de um trabalho científico é realizado através do editor e dos avaliadores (conhecidos no Brasil como referees, revisores ou assessores). Desta forma, cada manuscrito submetido à publicação em periódicos é analisado pelo assessor que emite seu parecer sobre o trabalho. Este parecer é enviado ao editor que promove o julgamento final do texto.

O sistema de avaliação por pares, no entanto, também é passível de condutas antiéticas. Por parte dos assessores podem ocorrer: emissão de parecer não verdadeiro, ou influenciado por interesses pessoais ou comerciais; retardo na apresentação do parecer, sem motivos coerentes ou para obter vantagens pessoais; ou ainda a apropriação de idéias do texto em exame. Uma das formas da comunidade científica tentar evitar tais distorções é a utilização de vários analisadores. Além disso, são enviados todos os pareceres sobre o trabalho analisado aos demais assessores, como forma de promover o controle de um avaliador sobre outro (PESSANHA, 1998).

O caráter confidencial no processo de avaliação de um trabalho também é bastante discutido em ética científica. Embora o grau de confidencialidade seja variável entre os periódicos, via de regra, os avaliadores desconhecem os autores e vice-versa. É uma forma de tentar evitar que hajam condutas antiéticas, positiva ou negativa, na emissão do parecer. No entanto, nem todos os periódicos adotam este sistema de avaliação conhecido como "avaliação às cegas". 
A FAPESP, com o objetivo de manter a credibilidade em seus processos de avaliação, solicita aos seus assessores que, antes de iniciarem a análise de um processo, considerem a possibilidade de haver algum tipo de conflito de interesse em relação ao documento recebido. Segundo a FAPESP, configuram conflito potencial de interesse situações como: participação atual ou anterior do assessor no projeto analisado; colaboração regular do assessor, em atividades de pesquisa ou publicações, com um dos pesquisadores solicitantes; relação orientador/orientado com o solicitante; interesse comercial do assessor na pesquisa proposta; relação familiar do assessor com um dos proponentes etc. Assim, caso seja observada uma ou mais circunstâncias que possa gerar conflito de interesse, solicita-se, por questões éticas, que o assessor devolva o processo recebido.

Atualmente uma das preocupações mais freqüente na comunidade científica é a proteção do conhecimento científico. Há anos, estabeleceu-se nos periódicos a descrição da data de recebimento do trabalho, como forma de identificar e julgar quem foi o primeiro a submeter e publicar um novo resultado de pesquisa. A criação de patentes de pesquisas também tem aumentado bastante nos últimos anos, como forma encontrada pelos pesquisadores de garantir direito à propriedade intelectual.

O Código de Ética dos Profissionais da Química aprovado pelo Conselho Federal de Química, embora date da década de 70 (Resolução Ordinária N 927/70), estabelece algumas condutas relacionadas à propriedade intelectual que não devem ser tomadas pelos profissionais da Química. O código determina, por exemplo, que o profissional não deve "usufruir de concepção ou estudos alheios sem fazer referência ao autor" ou "usufruir de planos ou projetos de outrem, sem autorização".

A conduta inadequada na comunicação científica levou a comunidade a criar comitês de ética específicos para tratarem desse tema. Em 1990, foi criado nos Estados Unidos o Comitê de Integridade Científica. A França criou em 1994 o Comitê de Ética para as Ciências do Centre National pour la Recherche Scientifique. Embora menos freqüente na área Química, vale ainda lembrar a existência de comitês e procedimentos especiais para a realização de pesquisas envolvendo seres humanos e animais de laboratório. Por fim, a preocupação ecológica também tem sido alvo de cuidados durante a realização de pesquisa de campo em ambientes de preservação ambiental, bem como a coleta de amostras em áreas de florestas, rios ou mares. 


\section{DE COMUNICAÇÃO CIENTÍFICA}

A produção e a divulgação do conhecimento científico envolvem diversas formas de comunicação, aqui organizadas de acordo com a espiral da cultura científica proposta por Carlos Vogt (2003) e anteriormente comentada.

PRODUÇÃO E DIFUSÃO DA CIÊNCIA: incluem os trabalhos direcionados à circulação do conhecimento científico entre os pares.

- Relatórios de pesquisa

- Artigos científicos

- Trabalhos apresentados em reuniões científicas

- Projetos de pesquisa

ENSINO DE CIÊNCIAS E FORMAÇÃO DE CIENTISTAS: incluem trabalhos nos quais cientistas e professores, ligados a universidades e instituições de ensino médio, levam a cultura científica aos estudantes.

- Artigos científicos de divulgação

- Artigos de educação em Ciência

- Materiais didáticos

ENSINO PARA A CIÊNCIA: incluem trabalhos nos quais tanto cientistas, quanto professores e diretores de museus levam a cultura científica para os jovens de um modo geral.

- Programas de extensão cultural da universidade, museus etc.

DIVULGAÇÃO DA CIÊNCIA: incluem trabalhos produzidos por jornalistas e cientistas destinados a levar a cultura científica à sociedade como um todo.

- Artigos de divulgação científica

Algumas dessas formas de comunicação científica serão descritas a seguir.

\section{$2.1 \quad$ RELATÓRIOS}

Os relatórios são documentos escritos nos quais são apresentados os resultados de um trabalho em realização ou recentemente concluído. Sua forma de apresentação é bem 
semelhante à dos artigos científicos, diferindo destes, sobretudo, na descrição detalhada dos materiais e métodos empregados e nos resultados obtidos.

Os principais componentes de um relatório são:

- Título

- Resumo

- Introdução

- Objetivos

- Materiais e Métodos

- Resultados e Discussão

- Conclusões

- Referências Bibliográficas

Os relatórios de aulas práticas de laboratório de ensino, embora também sejam relatos de trabalhos já realizados - tal como nos relatórios de pesquisa - têm alguns aspectos diferenciados quanto a objetivo, conteúdo e forma de apresentação. Tem se observado nas disciplinas experimentais dos cursos de Química, até mesmo em um mesma instituição, a falta de uniformidade ou padrão no formato dos relatórios exigidos em cada disciplina. Em alguns casos, a elaboração de um relatório é substituída pelo preenchimento de fichas ou pelo caderno de laboratório.

As distintas finalidades dos relatórios de laboratório também contribuem para a diversidade observada na forma de apresentação de tais documentos. Algumas disciplinas objetivam desenvolver nos alunos, através da elaboração de relatórios, a capacidade de relacionar a teoria e a prática, capacidade de interpretação e senso crítico dos resultados, organização formal de um texto científico, visando ampliar sua formação profissional. Nestes casos, costuma-se solicitar relatórios mais elaborados, semelhantes a artigos científicos. Os relatórios assim produzidos costumam seguir modelos como, por exemplo, o proposto por Luz Júnior et al. (2004) em artigo publicado na revista Química Nova:

Tratando-se de um relatório de uma disciplina experimental aconselhamos a seguinte seqüência:

- TÍTULO: Frase sucinta que indica o principal objetivo da experiência.

- RESUMO: Texto de no máximo cinco linhas, descrevendo o que foi feito, inclusive os resultados alcançados.

- INTRODUÇÃO: Descrição de toda teoria necessária ao entendimento da prática e da discussão dos resultados. [...] O objetivo do trabalho deve aparecer no último parágrafo da introdução, podendo ficar separado desta para maior destaque.

- PARTE EXPERIMENTAL: Descrever o procedimento experimental, ressaltando os principais materiais e equipamentos utilizados. Preferencialmente dividir em dois subitens: Materiais e Reagentes e Procedimento Experimental (Materiais e Métodos).

- RESUlTADOS: Consiste na apresentação de todos os dados colhidos em laboratório ou dos calculados decorrentes dos dados. Devem ser apresentados na forma de tabela, gráficos etc. [...] 
- DISCUSSÃO: Discutir os dados obtidos à luz da teoria exposta e comparar com os dados da literatura. [...]

- Obs.: Estes dois itens podem ser agrupados em um único item: RESULTADOS E DISCUSSÃO.

- CONCLUSÃO: Síntese pessoal sobre as conclusões alcançadas com o seu trabalho.

- REFERÊNCIAS: Livros e artigos usados para escrever o relatório. [...]

(Quimica Nova, v. 27, n.1, 164-168, 2004)

Por outro lado, alguns relatórios de laboratório de ensino destinam-se a descrever o experimento realizado de modo que o aluno demonstre compreender a teoria relacionada à prática. Ou seja, tais relatórios objetivam reforçar o aprendizado do conteúdo de uma disciplina. Assim, apresentam-se mais resumidos e mais direcionados ao experimento realizado, embora, de forma geral, mantenham o mesmo formato apresentado anteriormente.

Convém mencionar ainda que as partes que compõem um relatório devem ter uma divisão de conteúdo compatível com a importância de cada uma delas. O roteiro de laboratório adotado pela Faculdade de Engenharia Química da UNICAMP sugere a seguinte divisão: Introdução (10\%); Revisão Teórica (20\%); Materiais e Métodos (10\%); Resultados e Discussão (40\%); Conclusões e Sugestões (10\%) e Memória de Cálculo $(10 \%)$. Embora não específico para a área de Química, esse exemplo demonstra, em termos de proporção, como as partes de um relatório costumam ser distribuídas.

\section{$2.2 \quad$ ARTICOS CIENTÍFICOS}

Os artigos científicos destinados aos pares podem ser apresentados de diversas formas: artigos originais ou completos, notas ou comunicações curtas, artigos de revisão, artigos de divulgação.

\subsubsection{ARTIGOS ORIGINAIS DE PESQUISA}

São relatos definitivos de trabalhos originais ou apresentação de novos dados significativos sobre um assunto já estabelecido. O texto como um todo geralmente é mais resumido que o dos relatórios de pesquisa, sobretudo na descrição da metodologia empregada e na apresentação dos resultados.

O formato do artigo científico varia bastante de acordo com as regras estabelecidas pela revista na qual será publicado. Os artigos do periódico Química Nova, por exemplo, de modo geral, apresentam os seguintes componentes:

- Título

- Autores e Afiliações

- Abstract e Keywords 
- Introdução

- Parte Experimental

- Resultados e Discussão

- Conclusões

- Agradecimentos

- Referências

Cabe esclarecer que os artigos originais também são apresentados na forma de notas ou comunicações curtas. Estas são publicações que apresentam relatos concisos de trabalhos preliminares relevantes e, geralmente, não apresentam a divisão nas diversas seções que constam nos artigos completos. Estes artigos geralmente não apresentam a divisão do texto nas diversas seções que constam nos artigos completos. Periódicos internacionais como Journal of Materials Chemistry ou Molecular Biosystems apresentam a seção Communication nas quais podem ser encontrados esses tipos de artigos.

\subsubsection{ARTIGOS DE REVISÃO}

São trabalhos que integram, correlacionam e avaliam resultados de vários trabalhos publicados sobre um assunto particular. São acompanhados, portanto, de extensa revisão bibliográfica.

Algumas revistas costumam convidar pesquisadores qualificados em uma área ou assunto específico para escrever artigos de revisão, embora aceitem submissão livre. É desejável também que o autor tenha trabalhos originais de pesquisa publicados na área ou sobre o assunto que é objeto da revisão.

Os artigos de revisão são de especial importância para alunos que iniciam suas pesquisas, pois permitem uma visão geral dos principais trabalhos desenvolvidos na área, além de fornecerem ampla lista de referências bibliográficas úteis aos iniciantes e possibilitarem o reconhecimento dos principais grupos de pesquisa que desenvolvem trabalhos sobre determinado assunto.

Os artigos de revisão, de modo geral, abordam os seguintes aspectos:

ESTADO DA ARTE: apresenta uma síntese do conhecimento sobre determinado assunto, com ênfase na literatura mais recente, conforme demonstra o exemplo a seguir.

Em revisão recente desta técnica, Chester e Pinkstone ${ }^{1}$, em 2002, ressaltaram o crescimento de aplicações de SFC [...]. Nos sistemas unificados, desenvolvidos até então, foram empregados hélio para $\mathrm{CG}$ e $\mathrm{CO}_{2}$ para $\mathrm{SFC}$, independentemente ${ }^{26-30}$, metanol e éter dietílico como gás e líquido 24 .

(Quimica Nova, v.27, n.5, 747-753, 2004)

HISTÓRICO: examina o desenvolvimento histórico de determinada área do conhecimento. Aborda os trabalhos pioneiros na área, a mudança de perspectivas, o desenvolvimento de novas metodologias. Tais características podem ser observadas no exemplo a seguir. 
Os primeiros artigos envolvendo a cromatografia como uma Ciência foram publicados em 1906 por Michael Tswett, [...]Desde então, essa técnica desenvolveu-se e ampliou-se até uma forma instrumental com elevada sofisticação [...].

Na década de 70, os sistemas cromatográficos eram a GC e LC [...]. Nos anos 80, buscou-se aumento da resolução...

(Química Nova, v.27, n.5, 747-753, 2004)

COMPARAÇÃO/PERSPECTIVAS/APROXIMAÇÃO: examina criticamente duas ou mais maneiras de entendimento sobre um assunto particular. Relata ou aproxima resultados provenientes de campos do conhecimento diferentes sobre um assunto particular. O trecho do artigo exposto a seguir exemplifica essa característica.

Sallers e colaboradores ${ }^{117}$ demonstraram que o metilHg é decomposto fotolíticamente na superfície das águas, sendo este processo uma etapa importante no ciclo aquático do Hg.[...]

Um comportamento inverso foi obtido recentemente por Lean e Siciliano ${ }^{120}$, em águas da região do Quebec (Canadá) contaminadas por metilHg e expostas à radiação solar, pois ocorreu produção de metilHg e não fotodegradação, como encontrado nos trabalhos anteriores.

(Quimica Nova, v.27, n.4, 593-600, 2004)

Esses artigos não obedecem a uma divisão formal de tópicos presentes na maioria dos artigos científicos. Observe, por exemplo, como o autor do seguinte artigo de revisão estruturou seu texto.

\section{$\longrightarrow$ Título do artigo \\ TECNOLOGIA DE RECICLAGEM DOS POLÍMEROS}

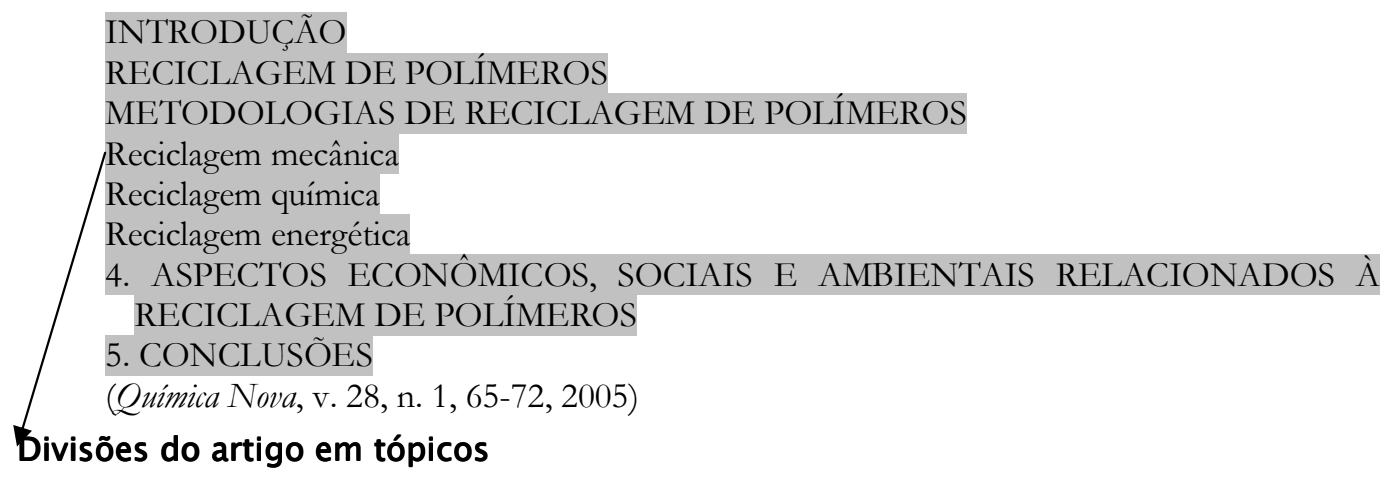

\subsection{TRABALHOS APRESENTADOS EM REUNIÕES CIENTÍFICAS}

Congressos, encontros e jornadas são eventos científicos nos quais vários pesquisadores de uma mesma área do conhecimento, como o CBQ (Congresso Brasileiro de Química), ou de uma mesma área de pesquisa, como o BMIC (Brazilian Meeting of Inorganic Chemistry), reúnem-se durante um certo período de tempo para apresentarem seus trabalhos mais recentes e debater sobre temas importantes na área. Esses eventos 
possibilitam aos pesquisadores interagir com outros colegas, discutir seus resultados e acompanhar a evolução das pesquisas desenvolvidas em seu país ou no mundo.

Diversas denominações têm sido dadas aos eventos científicos, tais como congressos, jornadas, simpósios, entre outras. Embora muitas destas definições sejam usadas como sinônimos, elas têm diferenças conceituais, sobretudo quanto ao aprofundamento do evento, ao tempo e à forma de realização. A seguir serão abordadas as principais denominações dadas aos eventos científicos.

O Congresso é um evento científico geralmente promovido e organizado por entidades ou associações de especialistas de uma determinada área do conhecimento. Seu objetivo é fazer com que seus participantes acompanhem, divulguem ou debatam sobre a evolução do conhecimento na área.

A Conferência, como evento geral, se aproxima bastante do Congresso, embora apresente uma abordagem de temas mais ampla que este. No entanto, a conferência geralmente não é promovida por uma única entidade em particular, mas por várias entidades de uma mesma área. Conferência é um termo também usado como sinônimo de palestra. Neste sentido, conferência não pode ser considerada um evento, mas uma exposição oral - geralmente de um convidado especial ou uma figura de destaque na área Palestra é denominada uma exposição oral em condições menos solenes que pode ocorrer no contexto de um evento ou realizada isoladamente, seguida ou não de debates com os ouvintes.

O Encontro denomina um evento de menor porte que um Congresso, embora também destinado ao debate sobre temas predeterminados e com diversas formas de apresentações em sessões. A Reunião deveria ser um evento mais restrito ainda que o próprio Encontro; muitas vezes, porém, é utilizada no sentido de Encontro ou Congresso. A Jornada é um encontro com tempo limitado, de poucos dias, embora também seja utilizada no sentido de Encontro.

O Simpósio é uma reunião destinada apenas a especialistas e destinada ao debate sobre temas já previamente determinados. Geralmente é um evento que versa sobre um único tema que venha sendo estudado por pesquisadores de diferentes instituições.

O Seminário é evento bem restrito, uma reunião onde os participantes expõem suas idéias e pesquisas, as quais são debatidas com os demais participantes. O seminário também é conhecido no sentido de exposição oral sobre um determinado tema geralmente uma atividade didático-científica que faz parte da vida acadêmica.

Em eventos de grande porte, ocorrem diversas formas de apresentação e discussão de trabalhos e/ou avanços de determinada área, como as sessões de comunicação oral, mesas redondas, sessões de apresentação de painéis. Nas Sessões de Comunicação Oral os pesquisadores apresentam resultados de pesquisas em desenvolvimento. As sessões de Mesa Redonda destinam-se à apresentação de pontos de vista distintos sobre uma mesma questão, cujo debate geralmente é realizado a partir da exposição de um dos participantes seguida da discussão crítica dos demais expositores. Nas Sessões de Apresentação em 
Painel, os trabalhos ficam expostos ao público e o autor fica à disposição para fornecer eventuais esclarecimentos ou discutir pontos relevantes de seu trabalho.

As Oficinas e os Workshops, embora possam ocorrer como evento científico restrito em número de expositores e participantes, geralmente são realizados no contexto de um evento de maior porte. As Oficinas e Workshops destinam-se à apresentação de novos trabalhos de pesquisa, novas metodologias, novas experiências, bem como à divulgação dos avanços técnicos ocorridos na área.

Eventos científicos nacionais da área de Química que se destacam são:

- Reunião Anual da Sociedade Brasileira de Química, promovida pela SBQ (Sociedade Brasileira de Química). Há 28 anos consecutivos a SBQ organiza suas reuniões anuais, as quais, em sua maioria, ocorreram no Estado de São Paulo. Nesse evento realizam-se Conferências, Simpósios, Workshops, mini-cursos, sessões de apresentação e discussão de painéis. Os trabalhos apresentados são organizados em diferentes seções como: Química Ambiental, Catálise, Ensino de Química, EletroQuímica e Eletroanalítica, Físico-Química, FotoQuímica, História da Química, Química Medicinal, Produtos Naturais, Analítica, Superfícies e Colóides, Inorgânica, Orgânica, Química Teórica, Biológica, Tecnológica e de Materiais.

- Congresso Brasileiro de Química promovido pela ABQ (Associação Brasileira de Química) todos os anos, nos meses de setembro, em um estado da federação diferente dos últimos três anos, os quais em sua maioria ocorrem em Estados do Norte e Nordeste. No evento são apresentados em painéis trabalhos de diversas áreas da Química: Alimentos, Solo, Métodos Instrumentais de Análises, Drogas, Educação, Energia, Novos Materiais etc. Este congresso conta ainda com palestras e mesas redondas, $W$ orkshops, e com a realização paralela de outros eventos como a Jornada Brasileira de Iniciação Científica em Química, a Maratona de Química, a Feira de Projetos de Química (FEPROQUIM) e ExpoQuímica (Show room de serviços e produtos).

Nos congressos são apresentados os resumos (que fazem parte dos anais do congresso ou do caderno de resumo) e os painéis. Neles também são feitas apresentações orais.

\subsubsection{RESUMOS}

O resumo, como indica o próprio nome, é um documento científico na forma escrita que deve apresentar, de maneira concisa, um trabalho realizado. Os resumos enviados para congressos devem obedecer às normas do evento. Geralmente é estabelecida uma quantidade máxima de palavras (200 a 500, em média). Além disso, deve 
conter ainda: TÍTULO, AUTOR(ES) E AFILIAÇÃO(ÕES), PALAVRAS-CHAVE (3 a 5, em média) e, às vezes, AGRADECIMENTOS e REFERÊNCIAS.

O corpo do resumo geralmente é um texto corrido, sem parágrafos. Em alguns casos pode ser solicitado que os resumos sejam divididos em seções bem definidas, como Introdução, Materiais e Métodos, Resultados, Discussão e Conclusões. Alguns eventos adotam as duas formas de submissão de trabalhos: o resumo curto do trabalho, bem mais simples, que é publicado no livro de resumos; e o resumo completo do trabalho divido em seções, geralmente disponibilizado on-line ou em CD.

Nas reuniões da SBQ, o modelo do resumo e do trabalho são disponibilizados na forma de template, no qual o autor preenche os espaços reservados para cada componente do texto. Observe abaixo exemplos de um mesmo trabalho enviados para $28^{a}$ Reunião Anual da SBQ, realizada em 2005. Neles, podem ser encontrados seus componentes básicos. Primeiramente, pode-se observar o resumo curto de um trabalho e, em seguida, o resumo completo do mesmo trabalho, o qual possui divisões em seções (Introdução, Resultados e Discussão, Conclusão e Agradecimentos).

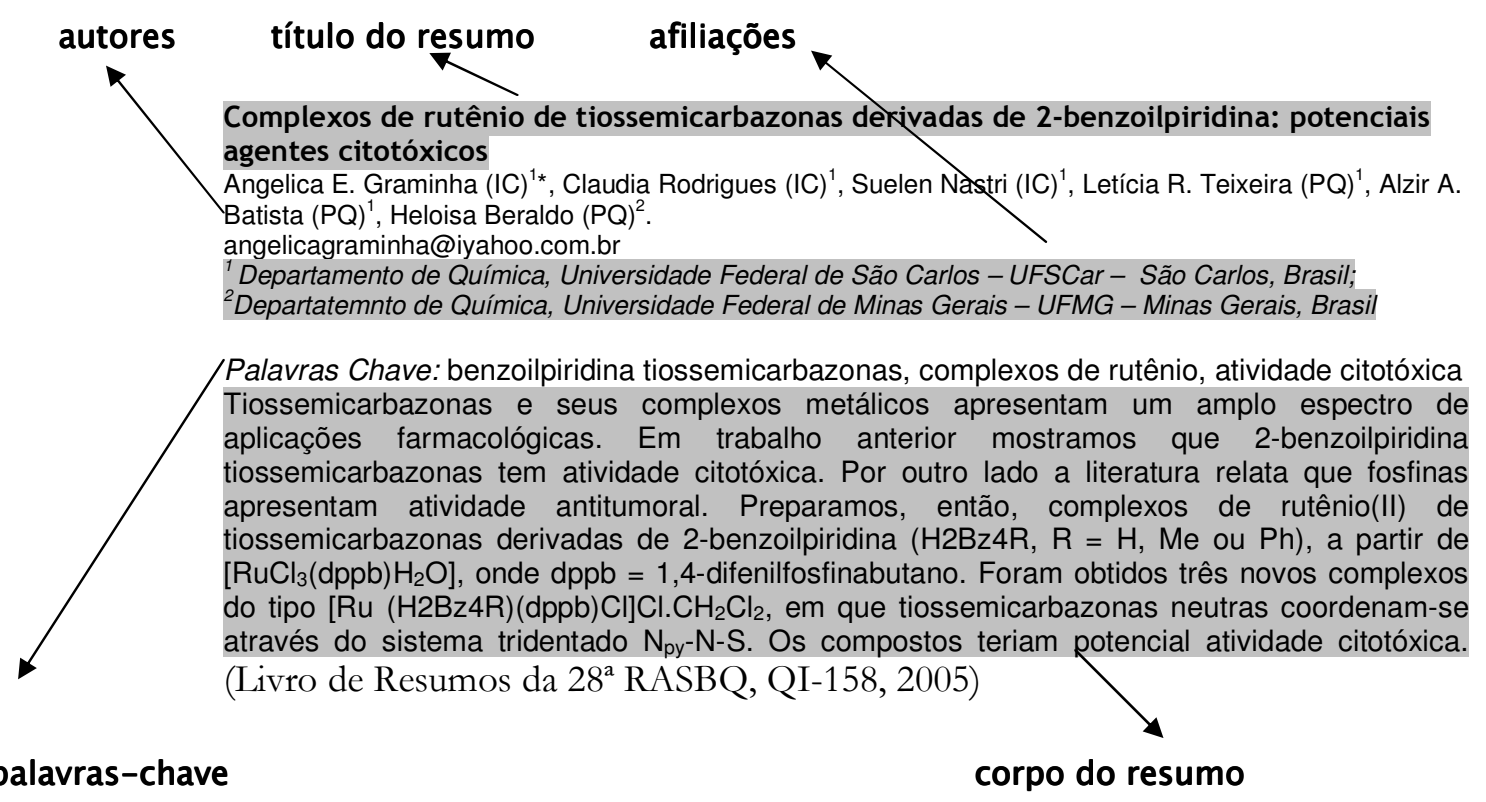




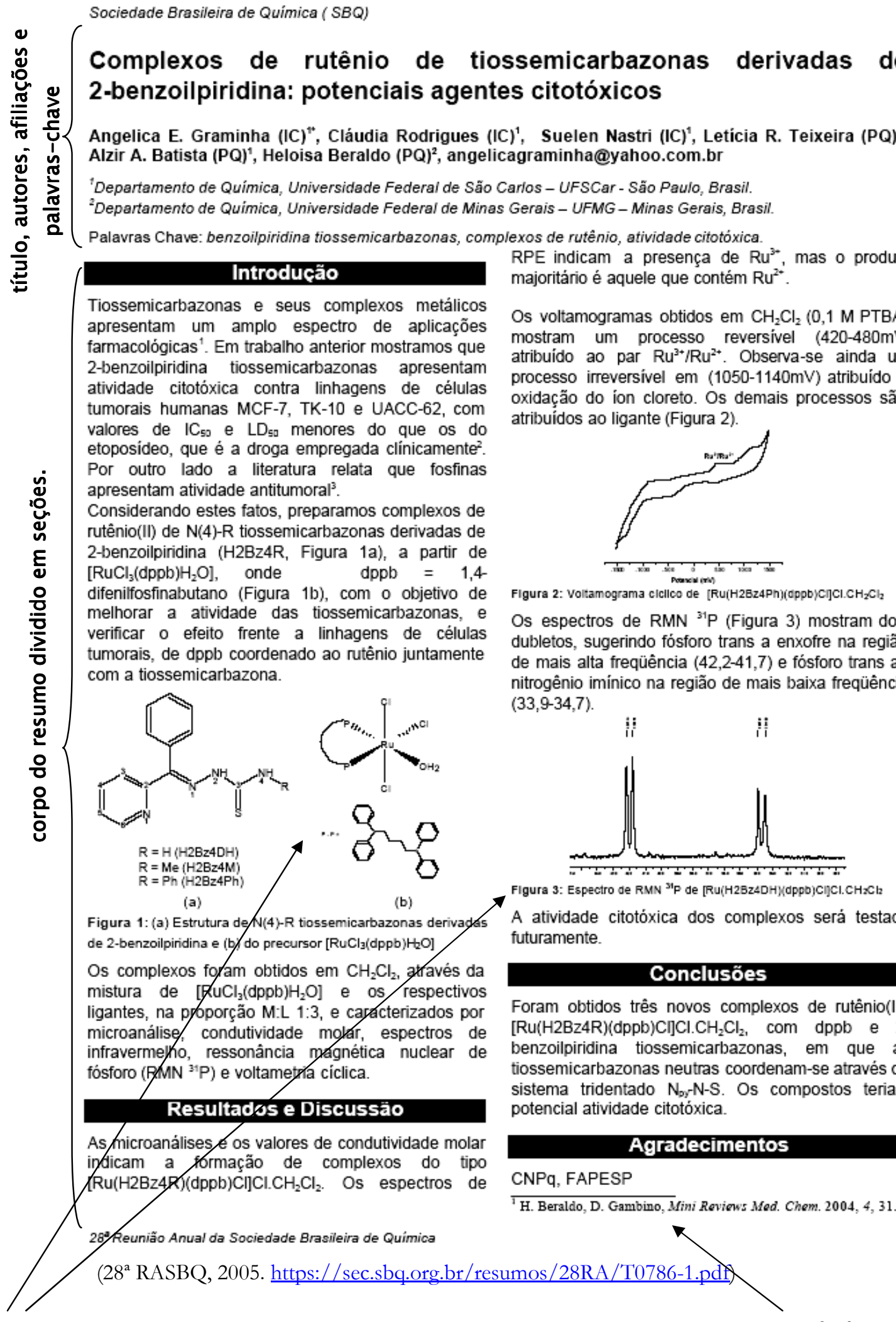

figuras podem ser agregadas ao resumo

agradecimentos e referências 


\subsubsection{PAINÉIS}

Os painéis são formas de comunicação escrita de trabalhos científicos, em sua maioria apresentados em congressos e outros eventos. A apresentação em painel é particularmente importante porque possibilita, no decorrer de sua exposição, discussões que venham a enriquecer o trabalho do pesquisador.

Um bom painel costuma transmitir de maneira resumida, clara e atraente, o resultado de um trabalho. Geralmente possui imagens (figuras, gráficos, esquemas, tabelas) e texto. Além disso, são elaborados com o intuito de fazer com que o leitor possa compreender as principais informações da pesquisa realizada, sem necessidade de explanação oral.

Os principais componentes de um painel são:

- Título

- Autores e Afiliações

- Introdução

- Materiais e Métodos (às vezes incluso na Introdução)

- Resultados (e Discussão)

- Conclusão

- Referências Bibliográficas e Agradecimentos (apenas as mais importantes)

A "estética" - sem exageros - é um aspecto bastante considerado na elaboração de um painel, pois pode ser um recurso atrativo inicial para que as pessoas o leiam. Via de regra, as seções de um painel são organizadas de modo que o leitor possa seguir facilmente a sua seqüência.

Observa-se que os textos de painéis geralmente são bastante resumidos, com o mínimo de palavras. Além disso, sempre que possível, são utilizadas diversas ilustrações, como por exemplo fluxogramas para descrição de métodos, figuras para demonstração de estruturas químicas, gráficos ou tabelas para apresentação de resultados etc.

Um painel costuma ser legível, em média, por até 1,2m de distância. Para isso, geralmente os autores utilizam fontes em tamanho grande (em média 40), espaçamento 1,5 ou duplo para não dificultar a leitura. O título costuma ser bem destacado, com fontes tamanho 70. Agradecimentos e referências bibliográficas aparecem em menor destaque com fontes de tamanho 25 ou 30. 
Exemplo de painel apresentado em congresso:

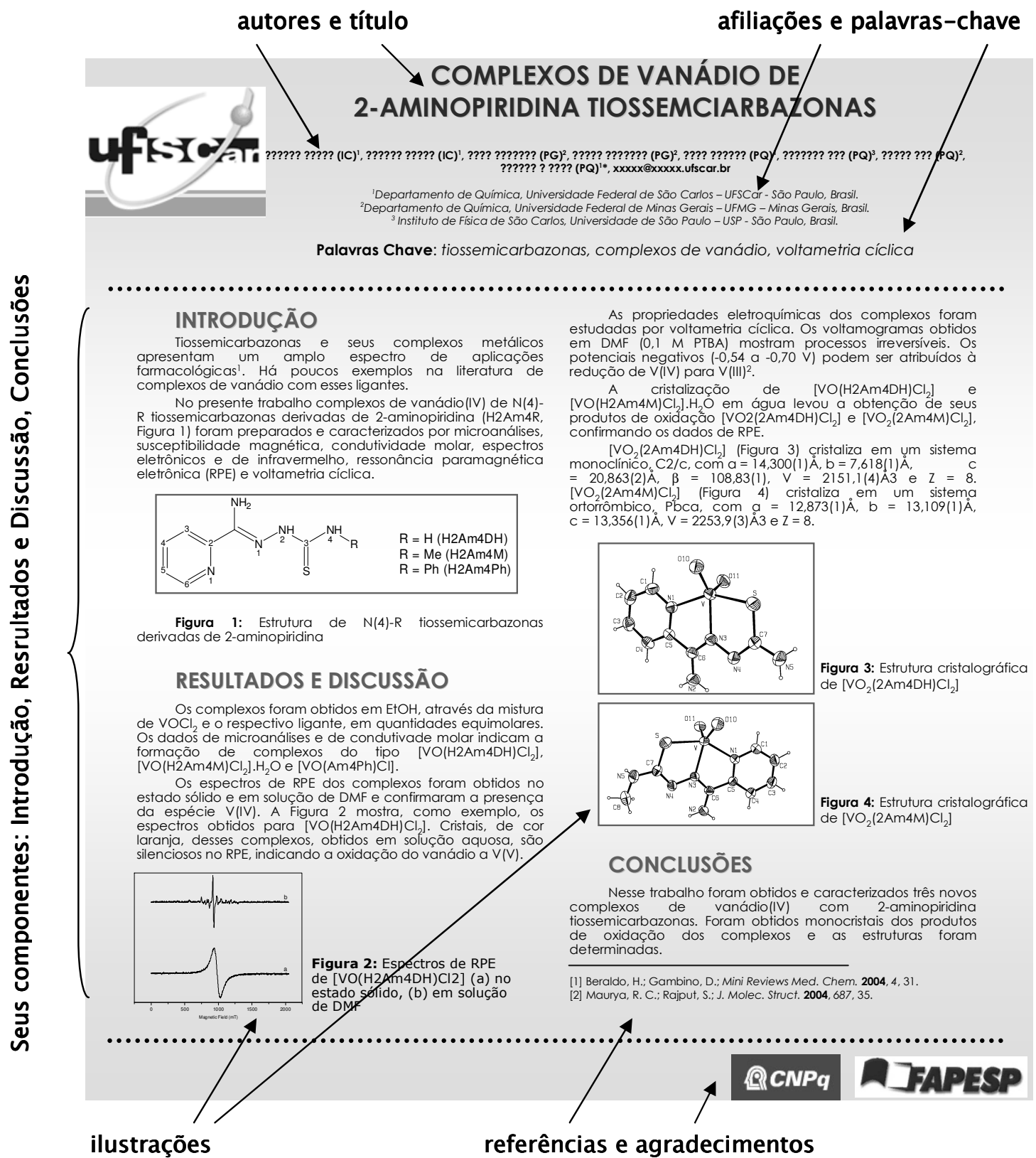

\subsubsection{APRESENTAÇÕES ORAIS}

São formas de comunicação científica, muito freqüentes em encontros científicos, que fazem parte da vida acadêmica e profissional desde o início da graduação, tais como seminários requeridos em disciplinas, apresentações de trabalhos de iniciação científica, monografias, dissertações, teses e apresentações de trabalhos em congressos. 
As apresentações orais são estruturadas considerados dois aspectos principais: elaboração dos slides ou transparências e exposição oral.

\section{a) Elaboração dos slides ou das transparências}

Para facilitar a leitura e visualização, são utilizadas fontes simples, como Times New Roman, de tamanho entre 18 e 24 . As cores também são escolhidas de modo a tornar as transparências ou slides atrativos e ao mesmo tempo evitar que a platéia tenha dificuldade para ler seus conteúdos. Tons pastel, por exemplo, não aparecem muito em um fundo branco e por isso costumam ser evitados.

Cada trabalho tem suas particularidades e, por esse motivo, geralmente não há regras que descrevam que tópicos devem estar presentes em slides ou transparências de apresentações orais. Observa-se, no entanto, que o costume é seguir os mesmos tópicos do trabalho de origem. Ao apresentar oralmente, por exemplo, um relatório de pesquisa, um autor estruturará sua apresentação em: Introdução; Objetivos; Materiais e Métodos; Resultados e Discussão; e Conclusões. Via de regra, na maioria das apresentações orais também observa-se a descrição de Agradecimentos e Referências Bibliográficas, embora bastante resumidos.

Geralmente, a apresentação oral tem início com a apresentação de slide ou transparência com o nome da instituição na qual o trabalho foi desenvolvido, o título do trabalho e o(s) autor(es). Em seguida é comum ser apresentado um esboço ou resumo do que será exposto, para que as pessoas possam tomar conhecimento do assunto a ser abordado. Observe os exemplos a seguir.

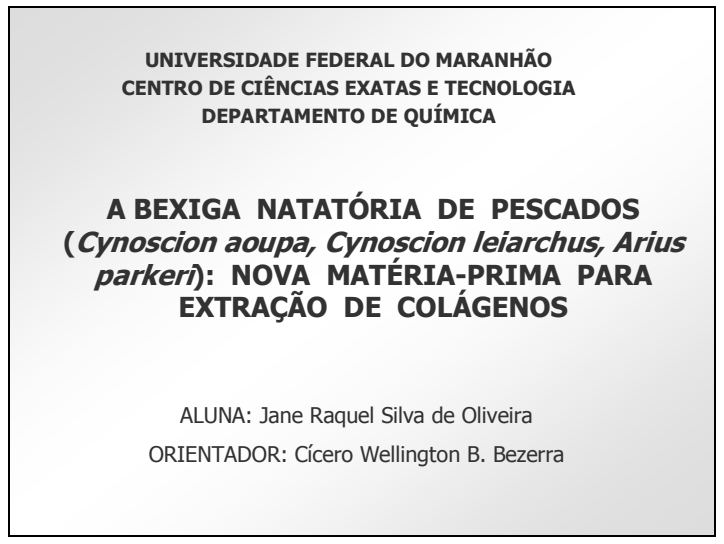

afiliação, título e autores

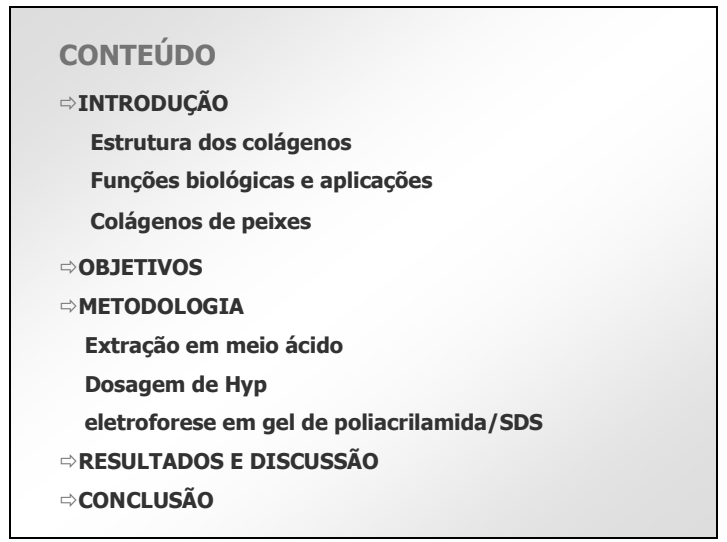

resumo da apresentação

As ilustrações freqüentemente ocorrem em apresentações orais. Para facilitar sua compreensão, fluxogramas, gráficos ou tabelas costumam ser apresentados de forma simples, com tamanho apropriado à leitura de seus componentes com destaque para os dados mais importantes. Além disso, sempre que possível, números apresentados em tabelas são arredondados - o número 50, por exemplo, é mais fácil de ler que 49,87. 


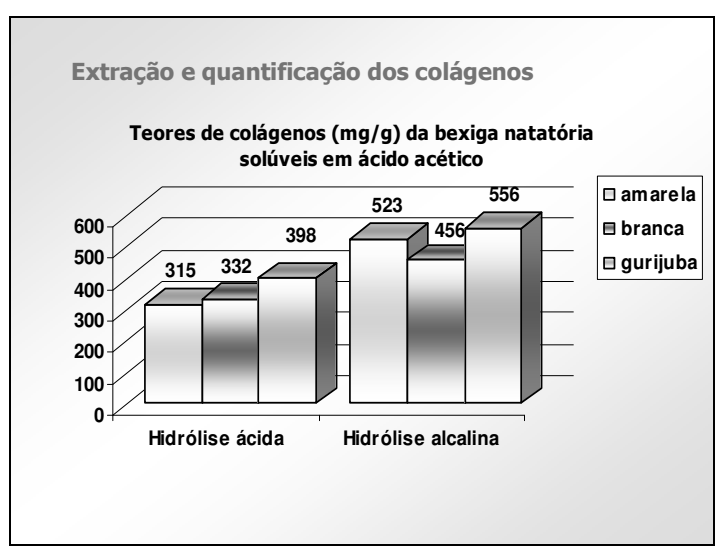

slide com gráfico
3.4. Identificação dos colágenos

Eletroforese em Gel de Poliacrilamida / SDS.

PREPARO DAS AMOSTRAS

Bexiga ácido Colágeno $\mathrm{NaCl}$ Precipitado

natatória acético solúvel $\underset{0,7 \mathrm{~N}}{\longrightarrow}$ salino

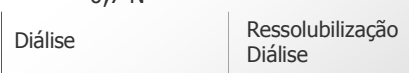

Tampão de amostra

Tris-HCl: pH 6,8 / SDS,

mercaptoetanol, azul
de bromofenol $/ 100^{\circ} \mathrm{C}$

Amostra 1

Amostra 2

slide com fluxograma

Geralmente ao elaborar a parte escrita de uma apresentação oral, os autores evitam escrever textos longos ou muitos tópicos por slide ou transparência; isso evita escrever todas palavras de sua apresentação diretamente nos slides.

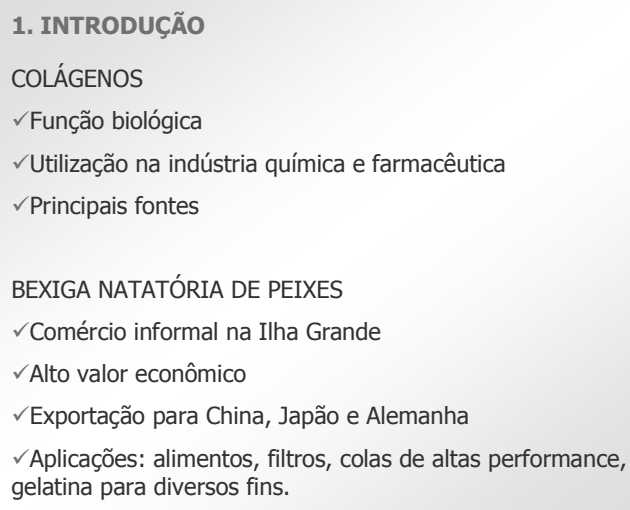

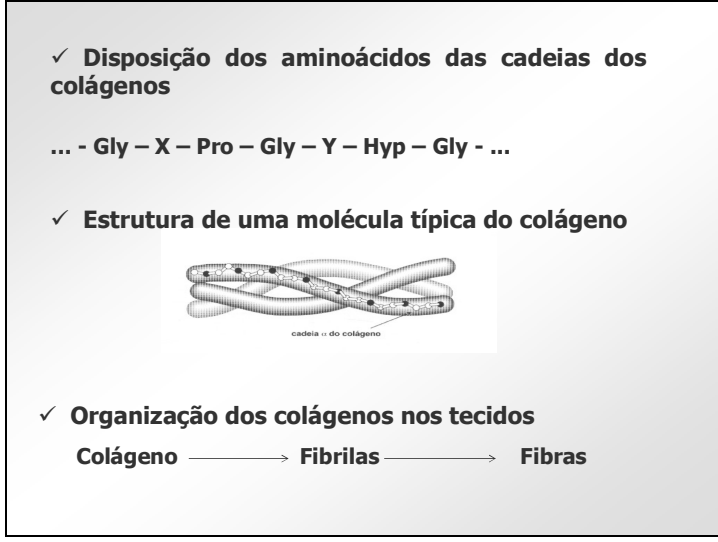

slides com conteúdo resumido em tópicos curtos

\section{b) Apresentação oral dos slides ou das transparências}

A fala lenta e o tom claro o suficiente para que todas as pessoas possam ouvir bem a apresentação são bastante observados em boas exposições orais. Para isso, quando possível, são utilizados microfones, especialmente se a apresentação for realizada em auditório grande.

Alguns cuidados também costumam ser adotados durante as apresentações orais, a fim de torná-las mais agradáveis para quem as assiste: olhar para toda a platéia a fim de verificar como as pessoas estão acompanhando o assunto exposto; não passar as transparências ou slides rápido demais para permitir que as pessoas tenham tempo para ler e refletir sobre os dados apresentados; utilizar a ponteira do laser ou outro instrumento da mesma natureza. 
O tempo das apresentações orais é um aspecto extremamente importante. Em congressos, geralmente o tempo é programado para determinado número de apresentações em um dia. Desta forma, atrasos podem alterar o planejamento realizado, o que é inconveniente para os próximos apresentadores e para a platéia. Em defesas de monografias, teses e dissertações o tempo costuma fazer parte da avaliação do aluno. Tanto apresentações rápidas quanto longas não são bem aceitas. Por esse motivo costuma-se revisar a apresentação com antecedência e observar se ela se ajusta ao tempo disponível para, se necessário, ampliá-la ou reduzi-la.

Observa-se, ainda, na escrita de textos científicos e nas apresentações orais, que os autores geralmente evitam o uso de jargões e expressões do dia-a-dia, a menos que sejam necessárias e, ainda assim, justificadas na própria apresentação.

\subsection{PROJETOS DE PESQUISA}

São documentos que apresentam uma proposta de trabalho de pesquisa envolvendo algum tema relevante para determinada área do conhecimento. Em muitos casos, esses projetos visam obter recursos para o desenvolvimento da pesquisa. Além disso, servem como roteiro de planejamento das atividades dos alunos.

As seções que compõem um projeto variam de acordo com as normas da instituição ou agência de apoio à pesquisa. A FAPESP preconiza os seguintes componentes de um projeto de pesquisa:

O projeto de pesquisa deve ser apresentado de maneira clara e resumida, ocupado no máximo 20 páginas datilografadas em espaço duplo. Deve compreender:

- Resumo (máximo 20 linhas);

- Introdução e justificativa, com síntese da bibliografia fundamental;

- Objetivos;

- Plano de trabalho e cronograma de sua execução;

- Material e métodos;

- Forma de análise dos resultados.

(www.fapesp.br)

Alguns projetos de pesquisa, que envolvem experimentos com animais ou humanos, necessitam de aprovação prévia de um comitê de ética, presente em várias instituições de ensino e pesquisa.

Uma das seções específicas de um projeto é o cronograma de atividades. Nele, o autor lista as atividades a serem desenvolvidas e o tempo de duração previsto para sua realização. A divisão cronológica pode ser mensal (em projetos de um ano) ou semestral para projetos mais longos (dois anos ou mais). Observe o exemplo fictício a seguir: 
Cronograma de atividades

\begin{tabular}{|c|c|c|c|c|c|c|c|c|c|c|c|c|}
\hline \multirow[b]{2}{*}{$\begin{array}{l}\text { ATIVIDADES } \\
\text { DESENVOLVIDAS }\end{array}$} & \multicolumn{12}{|c|}{2005} \\
\hline &.$\underline{\Xi}$ & $\stackrel{己}{己}$ & छีّ & 蒙 & 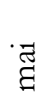 &.$\Xi$ &.$\Xi$ & \&్రి & $\breve{d}$ & $\vec{z}$ & 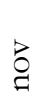 & D̃ \\
\hline Pesquisa bibliográfica & $\mathrm{X}$ & $\mathrm{X}$ & $\mathrm{X}$ & $\mathrm{X}$ & $\mathrm{X}$ & $\mathrm{X}$ & $\mathrm{X}$ & $\mathrm{X}$ & $\mathrm{X}$ & $\mathrm{X}$ & $\mathrm{X}$ & \\
\hline Coleta de amostras & $\mathrm{X}$ & & & $\mathrm{X}$ & & & & $\mathrm{X}$ & & & & \\
\hline Experimentos & $\mathrm{X}$ & $\mathrm{X}$ & $\mathrm{X}$ & $\mathrm{X}$ & $\mathrm{X}$ & $\mathrm{X}$ & $\mathrm{X}$ & $\mathrm{X}$ & $\mathrm{X}$ & $\mathrm{X}$ & $\mathrm{X}$ & \\
\hline Análise estatística & & & $\mathrm{X}$ & & & $\mathrm{X}$ & & & & & $\mathrm{X}$ & \\
\hline Redação dos Relatórios & & & & & & & $\mathrm{X}$ & & & & & $\mathrm{X}$ \\
\hline
\end{tabular}

O orçamento de uma pesquisa costuma estar presente em muitos projetos. Nesta seção todas as despesas previstas são detalhadas em itens distintos; os principais são:

- Despesas pessoais: diárias de viagens

- Material de consumo: reagentes, vidrarias, material de escritório

- Material permanente: equipamentos

- Transportes: viagens para coleta de amostras, apresentação dos resultados em congressos

- Outros: manutenção de equipamentos

\subsection{ARTIGOS CIENTÍFICOS DE DIVULGAÇÃO}

Os artigos de divulgação, destinados ao público especializado, apresentam assuntos relacionados a alguma área da Ciência e são redigidos de forma diferenciada dos artigos originais de pesquisa. Geralmente são direcionados a: estudantes de graduação, pós-graduação, pesquisadores de áreas diferentes, professores do ensino médio de Química etc.

Observe no exemplo abaixo que o assunto abordado está direcionado a estudantes e pesquisadores da área, embora haja preocupação do autor em conceituar os termos técnicos apresentados, facilitando a compreensão do texto.

O óxido nítrico é um gás incolor à temperatura ambiente, pouco solúvel em água, com uma concentração em uma solução saturada (1 atm de $\mathrm{NO})$ de $1,9 \mathrm{mM}\left(25^{\circ} \mathrm{C}\right)$, sendo muito mais solúvel em solventes apolares [...].Sendo uma espécie radicalar, o óxido nítrico é capaz de reagir rapidamente com outros radicais importantes do ponto de vista biológico, tais como oxigênio molecular e superóxido $\left(\mathrm{O}_{2}^{-}\right)$.[...] $\mathrm{O}$ óxido nítrico é também um neurotransmissor no cérebro $^{16}$, sendo a sua produção neuronal iniciada quando um neurônio emissor (neurônio pré-sináptico) libera um mensageiro químico, o glutamato [...]. (Química Nova, v. 22, n. 4, 584-589, 1999) 


\subsection{ARTIGOS RELACIONADOS À EDUCAÇÃO EM CIÊNCIA}

$\mathrm{Na}$ área de Química, alguns periódicos são destinados a publicar artigos que envolvem trabalhos relacionados ao ensino de Química. Esses artigos, produzidos por cientistas e professores, podem ser direcionados a professores do ensino médio e superior e relatam experiências desenvolvidas em sala de aula ou no laboratório, novas tecnologias de ensino e vários outros recursos que melhorem o ensino de Química.

Entre os periódicos internacionais, destaca-se o Journal of Chemical Education. Nos nacionais, temos a Química Nova na Escola. Além disso, a Química Nova, embora não publique apenas trabalhos da área, apresenta a seção Educação destinada a trabalhos de pesquisas relacionadas ao ensino de Química e divulgação de experiências inovadoras em todos os níveis de ensino.

Os exemplos a seguir foram extraídos de artigos da seção Educação da revista Quimica Nova.

\section{o autor relata a aplicação de experimentos de laboratório}

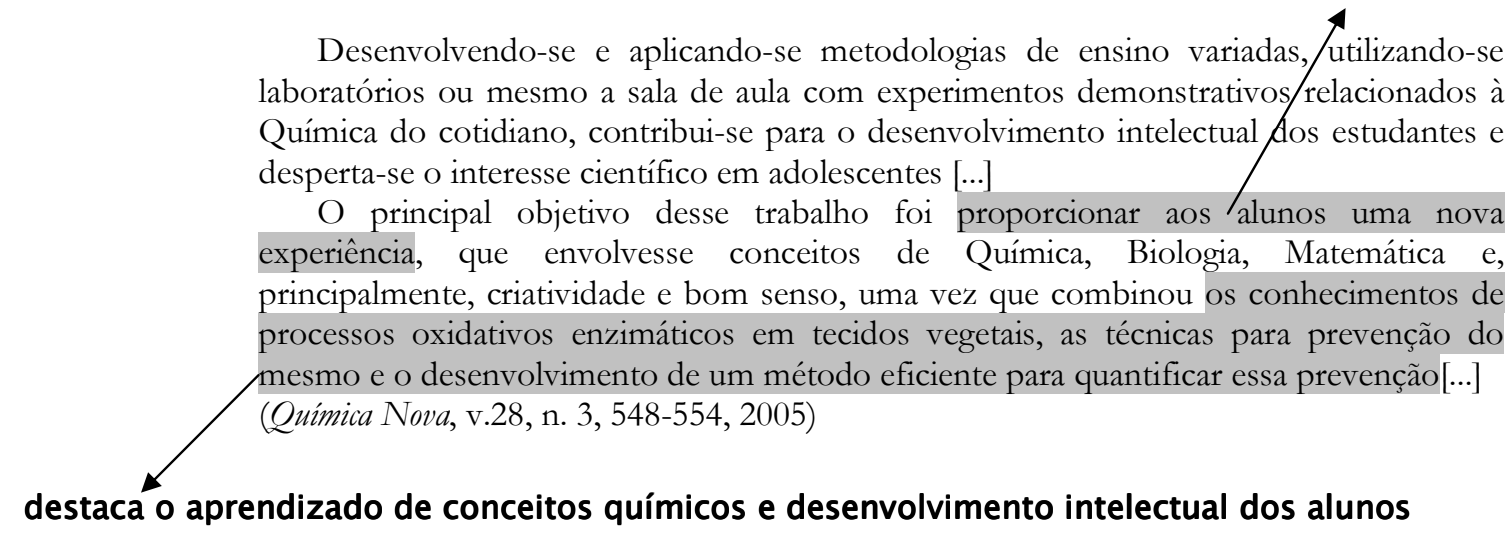

o autor apresenta os objetivos do trabalho do desenvolvido,

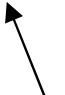

Assim, na forma de curso de extensão ministrado a alunos de graduação e pósgraduação, propusemos uma maneira de introduzir conceitos de Química quântica visando o entendimento de planejamento de fármacos. [...] Os problemas propostos foram trabalhados na forma de desenvolvimento de projetos, utilizando recursos computacionais para o cálculo de propriedades possivelmente importantes para o estudo /desenvolvido. [...] A concepção de conhecimento como produção coletiva torna a aprendizagem mais significativa, pois os alunos aprendem a utilizar seus conhecimentos para além da disciplina... (Química Nova, v. 28, n.2, 360-363, 2005)

descriçấo da metodologia aplicada as vantagens obtidas neste prócesso de ensino

\subsection{LIVROS DIDÁTICOS}


Outro tipo de publicação, também produzida por cientistas e professores, voltada ao ensino de Ciência, são os livros didáticos. Nestas publicações, o autor organiza de maneira didática os conhecimentos já bem fundamentados na literatura de Química que são importantes para a formação básica do aluno, seja no nível médio ou superior do ensino de Química.

\subsection{ARTIGOS DE DIVULGAÇÃO DA CIÊNCIA}

São publicações destinadas à sociedade em geral, que apresentam resultados de pesquisa científica de forma menos detalhada tecnicamente e com uma linguagem simples. Geralmente são publicados em jornais e revistas de maior circulação. No Brasil, as principais revistas de divulgação científica são: Pesquisa Fapesp, Ciência Hoje, Scientific American, Galileu e Superinteressante.

Não apenas a linguagem escrita dos artigos de divulgação é diferente daquela empregada nos artigos citados anteriormente, mas também sua forma de apresentação. Não há separação rígida das diversas seções do artigo científico original. Sua apresentação geralmente é permeada de figuras ilustrativas que facilitam a compreensão e atraem a atenção do leitor.

Em artigos de divulgação, geralmente a intenção do autor é "fisgar" o leitor logo nas primeiras linhas. O título geralmente é curto e bem atrativo. Além disso, o humor fino, usado com classe e bom senso, às vezes é utilizado para tornar mais agradáveis os textos de temas científicos. Observe estas características no exemplo a seguir.

\section{TRAQUINAGENS ETÍLICAS}

Nos próximos dias é quase certo que alguém lhe estenderá uma taça de espumante - ou de champanhe, a original francesa, se as finanças familiares estiverem no azul e dólar, bem comportado [...]. Mas é preciso ficar atento: tão ruim quanto exagerar na dose é consumir produtos de qualidade ou autenticidade duvidosa. [...] Nos últimos cinco anos, pesquisadores brasileiros passaram a estudar o grau de adulteração em produtos nacionais e estrangeiros [...] (Pesquisa Fapesp, n.94, 72-75, 2003)

Outra característica comum a este tipo de artigo é a simplicidade da linguagem, a fim de tornar o texto acessível a um público heterogêneo. Os conceitos científicos costumam ser explicados através de analogias fáceis de serem compreendidas, como demonstrado no seguinte exemplo:

[...] Por perder um elétron é que o óxido nítrico se torna muito reativo - com fome de elétron, digamos - e adere rapidamente a outras moléculas [...]

(Pesquisa Fapesp, n.111, 46-49, 2005)

As fórmulas matemáticas costumam ser evitadas, embora se necessárias, o significado das variáveis e unidades são explicados. O significado de siglas sempre é 
descrito, por extenso, no próprio texto. Além disso, ao longo do texto, as siglas são relembradas para que o leitor não precise retornar ao ponto inicial no qual ela foi descrita. Observe o exemplo abaixo:

A lecitina da pitomba, também conhecida pela sigla TEL, de Talisia esculenta lectin, mostrouse versátil ao inibir o desenvolvimento de fungos [...]

(Pesquisa Fapesp, n.82, 48-49, 2002)

Não é comum o uso de primeira pessoa em artigos de divulgação científica. Em geral os depoimentos pessoais de um pesquisador sobre o assunto são citados entre aspas ao longo do texto.

No final do ano passado, conta Mariângela, a viabilidade da técnica da pastilha foi comprovada. "Agora, na segunda fase do projeto, estamos trabalhando na simplificação e viabilização econômica", diz.

(Pesquisa Fapesp, n.90, 74-77, 2003)

Os artigos de divulgação científica, em sua maioria, não apresentam a lista de autores da pesquisa e suas respectivas afiliações. Assim, ao citar o nome de um pesquisador no texto, geralmente são descritas também sua atividade e instituição onde trabalha.

"Mas em alguns casos, percebemos até sete períodos distintos", comenta o físico Alberto Tufaile, da Universidade de São Paulo (USP), estudioso de sistemas caóticos em meios líquidos...

(Pesquisa Fapesp, n.117, 58-61, 2005)

As ilustrações, assim como boxes ou textos auxiliares, são recursos bastante utilizados para atrair a atenção do leitor e para facilitar a explicação de tópicos mais complexos. É possível encontrar pequeno glossário nesses artigos. 


\subsection{TÍTULO}

O título deve refletir claramente o conteúdo do trabalho e transmitir o máximo de informações com o mínimo de palavras. Essa tarefa não simples. Por esse motivo, a escolha do título geralmente é uma das últimas realizações na redação de qualquer documento científico. Via de regra, somente após a conclusão do trabalho, é possível uma visão global a seu respeito e a conseqüente produção do título adequado. A seguir podemos observar uma das principais dificuldades na elaboração de um título: fazê-lo claro e resumido.

O seguinte título:

DETERMINAÇÃO DA COMPOSIÇÃO IÔNICA MAJORITÁRIA DE AMOSTRAS DE ÁGUA DE CHUVA DA REGIÃO CENTRAL DA CIDADE DE SÃO PAULO (Exemplo fictício)

Poderia ser resumido da seguinte forma (detalhes como "amostras da região central" podem ser citadas no resumo):

COMPOSIÇÃO IÔNICA MAJORITÁRIA DE ÁGUAS DE CHUVA NO CENTRO DA CIDADE DE SÃO PAULO

(Quimica Nova, v.27, n.6, 855-861, 2004)

O uso de subtítulo pode ser bastante oportuno se o título for muito longo ou quando se pretende explicar melhor o título, como demonstram os exemplos a seguir.

ANÁLISE DE IMAGEM EM QUÍMICA ANALÍTICA: EMPREGANDO METODOLOGIAS SIMPLES E DIDÁTICAS PARA ENTENDER O ESCURECIMENTO DE TECIDOS VEGETAIS

(Química Nova, v.28, n.3, 548-554, 2008)

SÍNTESE QUÍMICA E ENZIMÁTICA DE PEPTÍDEOS: PRINCÍPIOS BÁSICOS E APLICAÇÕES

(Quimica Nova, v.27, n.5, 781-789, 2004) 
O manuseio de revistas científicas como a Química Nova permite identificar outros tipos de títulos, como por exemplo, títulos que transmitem a idéia de questionamento, os quais são construídos com a inserção de um ponto de interrogação.

INDICADORES NATURAIS DE PH: USAR PAPEL OU SOLUÇÃO?

(Quimica Nova, v. 25, n.4, 684-688, 2002)

Títulos vagos ou genéricos que não especifiquem exatamente o conteúdo do trabalho devem ser evitados. Expressões como "Estudos sobre...", “Observações sobre..." devem ser evitadas, pois aumentam o tamanho do título e podem não contribuir para explicar o conteúdo do trabalho. Expressões como "Aspectos de..." podem ainda causar a impressão de que o trabalho é superficial. É recomendável também evitar abreviaturas e siglas no título, a não ser aquelas amplamente conhecidas e aceitas pelo público ao qual se destina o trabalho.

Cabe ressaltar que palavras contidas no título em língua diferente daquela adotada no trabalho devem ser destacadas em itálico, como palavras latinas ou até mesmo palavras em inglês em título escrito em português.

\subsection{AUTORES}

Os autores de um trabalho são, obviamente, aqueles que participaram efetivamente do desenvolvimento da pesquisa e da redação do manuscrito a ser submetido para publicação.

Quem publica ou pretende publicar regularmente deve adotar uma forma constante de colocar seu nome nos trabalhos. Assim, não é recomendável, por exemplo, que Guilherme Henrique Paulino publique seus trabalhos como G.H. Paulino e, às vezes, como G. Paulino. Um leitor pode pensar que são autores diferentes; ou alguém que necessite fazer uma busca bibliográfica das publicações de G.H. Paulino pode deixar de ler outros trabalhos que aparecem com outros nomes.

Manter a mesma forma de apresentação da autoria de um trabalho nem sempre é possível, muitos periódicos têm formas distintas de apresentar o nome dos autores de um trabalho. Alguns periódicos podem colocar por extenso apenas o último sobrenome e abreviar os demais. Outros podem colocar todos os nomes e sobrenomes dos autores por extenso.

Nomes com terminação em Filho ou Junior podem causar alguns enganos. Se um autor optar, por exemplo, por publicar como G.H. Paulino Filho, há a possibilidade de um leitor que não entenda português não compreender a palavra (filho) como indicativo de parentesco. Assim, este leitor pode fazer buscas de outros trabalhos publicados por Filho, ou enviar uma carta ao Dr. Neto. Neste caso, recomenda-se abolir o nome Filho, Júnior, Neto, caso não haja parentes que também publiquem com o mesmo nome. Outra 
possibilidade é unir, através de hífen, o nome Filho ao sobrenome. No exemplo citado, o autor passaria, então, a ser conhecido nas publicações como G.H Paulino-Fillho.

Observe estes exemplos encontrados em publicações científicas:

Karina Omuro Lupetti, Lucinéia Cristina de Carvalho, André Farias de Moura e Orlando Fatibello-Filho*

(Química Nova, v.28, n.3, 548-554, 2005)

Leonardo de Santos Andrade, Romeu C. Rocha-Filho*, Nerilso Bocchi e Sonia A. Biaggio

(Química Nova, v. 27, n.6, 866-872, 2004)

A seqüência de autores é bastante variável e não há consenso entre os pesquisadores sobre a forma mais adequada de distribuir os nomes daqueles que participaram na execução do trabalho. $\mathrm{Na}$ área de Química, o primeiro autor geralmente é o autor principal, aquele que mais dedicou tempo e esforço para sua realização. O último autor apresentado na seqüência de autores é geralmente o orientador do trabalho, que provavelmente idealizou a pesquisa, teve grande participação intelectual e forneceu infraestrutura para sua execução. É reconhecido no meio científico como o idealizador e organizador da pesquisa.

Diversos periódicos solicitam a indicação do autor para correspondência. $\mathrm{Na}$ revista Química Nova esta indicação é feita através de uma nota de rodapé na primeira página do artigo apresentando o e-mail do autor, o qual representa, portanto, o autor responsável pelo trabalho. Será endereçada a ele a correspondência do editor da revista ou de leitores do seu artigo. Observe o exemplo a seguir:

\section{Emy Komatsu e Jorge Moreira Vaz* \\ $[\ldots]$ \\ *email: jmvaz@net.ipen.br \\ (Química Nova, v.27, n.5, 720-724, 2004)}

\subsection{AFILIAÇÕES}

Os artigos publicados em periódicos e os trabalhos apresentados em congressos requerem a apresentação das afiliações institucionais ou acadêmicas dos autores. $\mathrm{O}$ objetivo é permitir que os leitores reconheçam as instituições que desenvolvem um determinado tipo de pesquisa ou, se assim desejarem, entrem em contato com os autores do trabalho.

Quando todos os autores pertencem à mesma instituição torna-se mais simples sua apresentação. Quando os autores pertencem a instituições diferentes deve ser apresentada a afiliação de cada autor. Desta forma, os autores podem ser divididos em grupos separados por afiliação - modelo adotado pelo periódico Química Nova. 
Observe o exemplo a seguir:

Tatiana F. M. Leal, Anna P. G. Fontenele e Jairo J. Pedrotti*

Departamento de Química, Universidade Presbiteriana Mackenzie, Rua Itambé, 45, 01239902 São Paulo - SP

Adalgiza Fornaro

Departamento de Ciências Atmosféricas, Instituto de Astronomia, Geofísica e Ciências Atmosféricas, USP, Rua Matão, 1226, 05508-900 São Paulo - SP

(Quimica Nova, v. 27, n.6, 855-861, 2004)

Cada periódico ou evento tem sua forma específica de apresentação de nomes das instituições e seus endereços. O conteúdo pode variar desde apenas o nome da instituição até seu endereço completo, telefone para contato e e-mail dos autores.

Outras formas de apresentar as afiliações dos autores podem ser encontradas na literatura, como a indicação através de números ou asteriscos sobrescritos após o nome de cada autor. Modificando-se o exemplo anterior, poderíamos ter também a seguinte forma de apresentação:

Tatiana F. M. Leal ${ }^{1}$, Anna P. G. Fontenele ${ }^{1}$, Adalgiza Fornaro ${ }^{2}$, Jairo J. Pedrotti ${ }^{1}$ ${ }^{1}$ Departamento de Química, Universidade Presbiteriana Mackenzie, Rua Itambé, 45, 01239902 São Paulo - SP

${ }^{2}$ Departamento de Ciências Atmosféricas, Instituto de Astronomia, Geofísica e Ciências Atmosféricas, USP, Rua Matão, 1226, 05508-900 São Paulo - SP

\section{$3.4 \quad$ RESUMO}

O resumo é o texto no qual o autor deve apresentar, de forma concisa, o trabalho realizado. O resumo é um componente extremamente importante em publicações científicas, pois geralmente é o primeiro texto lido pelo examinador da monografia, tese ou dissertação, bem como pelo assessor do periódico para quem o artigo é enviado. Se, ao analisar o resumo de um trabalho, um leitor não compreender plenamente o conteúdo da pesquisa ou não for convencido de sua relevância, poderá decidir por não ler o trabalho na íntegra.

Os resumos fazem parte de diversos documentos científicos. Em muitos bancos de dados de pesquisa de literatura em Ciência, o resumo é o único componente do texto disponível para consulta. Os resumos aparecem em relatórios de pesquisa, projetos, monografias, teses e dissertações, geralmente ocupando uma página do texto. Em artigos e publicações em congressos são bem mais resumidos, pois o número de palavras ou de caracteres é bastante limitado, de acordo com o tipo de trabalho ou com as normas especificas de cada periódico ou evento. Para o caso da revista Química Nova, o número máximo de caracteres é 100.

Na maioria dos documentos científicos, o resumo contém: 
A QUESTÃO ABORDADA NO TRABALHO: razão pela qual foi realizado o trabalho, seguida da descrição objetiva do que foi feito.

MÉTODOS UTILIZADOS: citação simples das técnicas aplicadas.

PRINCIPAIS RESULTADOS E CONCLUSÕES: citação dos dados mais relevantes, informando valores e intervalos de confiança.

Pelo fato de a revista Química Nova não publicar resumos em português (apenas o Abstract), os exemplos de resumos apresentados neste trabalho foram extraídos da revista Eclética Química.

Observe como o autor estrutura o resumo a seguir:

\section{o autor apresenta a razão pela qual seu trabalho foi realizado}

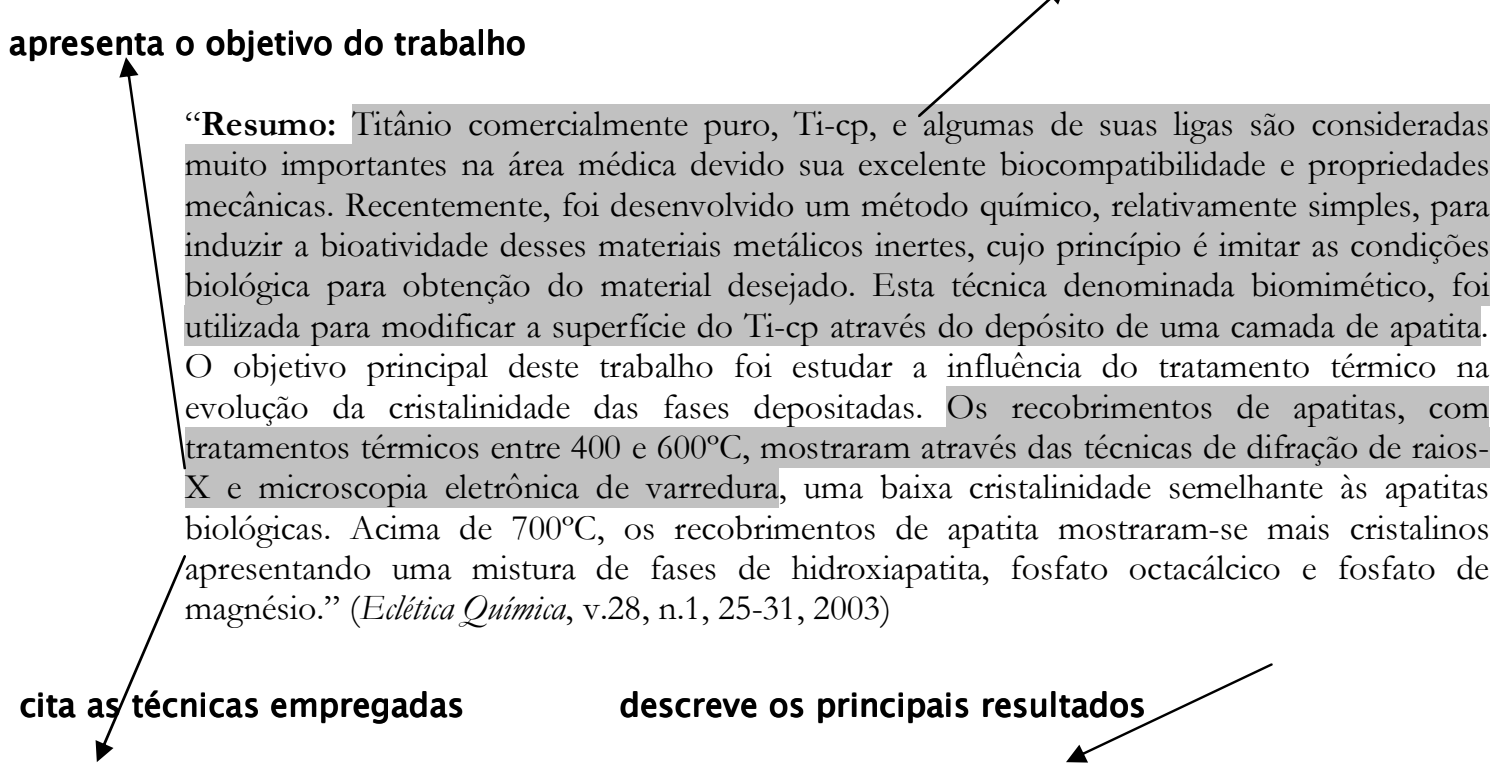

Em muitos casos, o resumo é iniciado pela apresentação direta do que foi realizado na pesquisa ou do seu objetivo principal. Os textos assim estruturados são mais resumidos e colocam o leitor em contato direto com o foco principal do trabalho. Observe o exemplo a seguir: 
o autor apresenta, em um só parágrafo, o objetivo do trabalho e a principal técnica empregada

Resumo: O objetivo deste trabalho foi caracterizar ácidos húmicos (HA) de diferentes origens por eletroforese capilar de zona (CZE) e avaliar a influência da concentração do tampão borato nesta caracterização. Os resultados mostraram que HA de diferentes origens podem ser rapidamente caracterizados por CZE. Por essa técnica, a caracterização de HA é devido a diferenças na razão carga/tamanho e das propriedades dos componentes individuais e duas origens. (Eclética Química, v. 29, n.2, 47-52, 2004).

descreve os principais resultados do trabalho

Outras características dos resumos ainda podem ser destacadas:

- Devido ao seu tamanho, no resumo não costumam ser apresentados detalhes sobre a metodologia e os reagentes empregados, a não ser que o trabalho proponha nova metodologia ou modificações em metodologia já estabelecida;

- Costuma-se evitar também o uso de abreviaturas, a não ser aquelas amplamente aceitas;

- Se um conjunto de palavras for utilizado várias vezes, pode-se abreviá-la, indicando seu significado no próprio resumo, no primeiro momento em que aparece;

- Citações bibliográficas não são usadas, pois se o resumo for indexado e o leitor não tiver acesso ao texto completo, a citação ficará sem sentido.

\subsection{PALAVRAS-CHAVE}

As palavras-chave (Keywords) são exigidas em diversos artigos científicos e em trabalhos enviados para congresso. São poucas palavras - geralmente de três a cinco - que expressam o tema ou assunto abordado no trabalho.

São usadas para indexação de trabalhos científicos. Atualmente, com os diversos bancos de dados eletrônicos, nos quais muitos leitores costumam pesquisar trabalhos através de palavras-chave, eles tornaram-se mais importantes. Por esse motivo, é importante selecionar com cuidado as palavras-chave de um trabalho.

Ao selecionar as palavras-chave, os autores costumam evitar o uso de palavras vagas ou pouco específicas, que não possibilitem o direcionamento de leitores interessados em pesquisar especificamente um determinado tema.

Extrair palavras do título ou do próprio resumo pode facilitar a escolha das palavras-chave. Isto pode ser observado no exemplo a seguir, no qual foram descritos o título do artigo e suas respectivas palavras-chave. 


\section{ESTABILIZAÇÃO DO SOLO CONTAMINADO COM ZINCO USANDO ZEÓLITAS SINTETIZADAS A PARTIR DE CINZAS DE CARVÃO}

Palavras-chave: zeólita, estabilização, solo contaminado

(Quimica Nova, v.27, n.4, 582-585, 2004)

Além disso, alguns periódicos - como o Journal of Chemical Education - dispõem de uma lista de palavras-chave para que o autor selecione as mais adequadas ao seu trabalho.

\subsection{INTRODUÇÃO}

É a seção do texto na qual são apresentados o tema principal do trabalho e as necessárias justificativas para sua realização, geralmente apoiadas em dados da literatura relacionados à pesquisa em questão.

A introdução pode ser bastante extensa como nas teses de doutorado ou sucinta como em muitos artigos científicos. De modo geral, a Introdução contém alguns elementos principais, tais como:

O ASSUNTO QUE FOI INVESTIGADO: sobre o que trata o trabalho.

O ESTADO DA ARTE: o que já se sabe sobre o assunto.

O QUE NÃO SE SABE SOBRE O ASSUNTO: pontos desconhecidos ou polêmicos existentes na literatura.

O OBJETIVO DO TRABALHO: a proposta do trabalho ou pergunta que pretende responder, enfatizando sua importância.

Nos artigos e relatórios de pesquisa é comum a introdução ser redigida em um único tópico, como demonstrado no exemplo a seguir. No entanto, em monografias, teses, dissertações e projetos de pesquisa é comum dividir os elementos da introdução em tópicos bem distintos. Inicialmente apresenta-se uma introdução curta na qual o tema do trabalho é apresentado e sua importância é justificada. Segue-se com a Revisão da Literatura (ou Revisão Bibliográfica), bem mais extensa e aprofundada, sobre o que se conhece a respeito do tema estudado. Em alguns casos, a Introdução pode ser dividida em subtópicos, como demonstrado no exemplo, extraído de uma dissertação de mestrado, exposto mais adiante. E por último apresenta-se claramente o que se pretende fazer no tópico Objetivos, que pode às vezes ser subdividido em Objetivos Específicos.

Exemplo de Introdução reproduzida de um artigo: 
apresenta em seguida o que se conhece

na literatura sobre $o$ assunto

o autor apresenta inicialmente

o sistema investigado

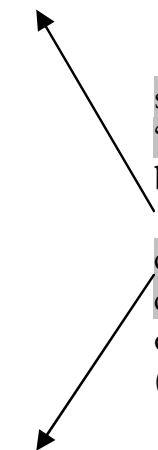

Espécies da família Myrtaceae encontram-se distribuídas em regiões tropicais e subtropicais ${ }^{1}[\ldots]$. Melaleuca alternifolia Cheel é comumente conhecida na Austrália como "árvore de chá" [...] A constituição Química do óleo essencial das folhas de M. alternifolia é bem conhecida ${ }^{3-7}$, sendo rico em terpinen-4-ol [...]

Embora vários trabalhos relatando a composição Química de óleos essenciais de folhas de $M$. alternifolia sejam encontrados na literatura, nenhum estudo químico de outras partes desta planta foi ainda descrito [...] O presente trabalho relata o primeiro estudo químico do caule e da casca de $M$. alternifolia...

(Química Nova, v.27, n.4, 536-539, 2004)

mostra o que não se conhece na literatura, que, neste exemplo, serve de base para justificar a importância do trabalho

apresenta o que foi estudado em seu trabalho

No exemplo a seguir apresenta-se uma Introdução de uma dissertação de mestrado e suas divisões características.

\section{INTRODUÇÃO}

1.1 Tuberculose e Outras Doenças Micobacterianas

A tuberculose é uma doença grave relatada durante toda a história [...]

1.2 Micobactérias

O gênero Mycobacterium contém um grande número de espécies [...]

1.3 Aplicações de RMN no Estudo da Composição Química de Bactérias

A técnica de ressonância magnética (RMN) é um método [...]

1.4 Aplicações da Espectroscopia de FTIR para Estudo de Bactérias

A espectroscopia no infravermelho que vem sendo usada [...]

\section{OBJETIVOS}

O objetivo deste trabalho é estudar a composição Química das micobactérias com as espectroscopias de RMN e FTIR.[...]

\subsection{Objetivos Específicos}

1) Identificar na composição Química das micobactérias ( $M$. smegmatis, $M$. fortuitum,(...)) as macromoléculas como proteínas, lipídeos e polissacarídeos por FTIR e RMN de ${ }^{13} \mathrm{C}$ em estado sólido;

2) Comparar a composição Química de bactérias de espécies diferentes;

3) Acompanhar a mudança na composição Química do Mycobacterium smegmatis, em diferentes tempos de cultivo;

4) Acompanhar a mudança na composição Química do Mycobacterium smegmatis, em diferentes meios de cultura.

(Tsukahara, Milena. Dissertação de Mestrado. IQSC/USP, 2005)

Alguns cuidados costumam ser adotados pelos autores na elaboração da Introdução, tais como: 
- Apresentar claramente o que especificamente foi realizado no trabalho. Evitar apresentar de maneira vaga o problema de pesquisa abordado;

- Evitar apresentar na revisão bibliográfica uma extensa lista de autores com os principais resultados ou conclusões de cada um, sem no entanto correlacionar as informações entre si, fazer análises dos resultados dos autores e discutir a relação destes com o trabalho de pesquisa em questão.

\subsection{MATERIAIS E MÉTODOS}

Em Química, esta seção do texto também pode ser denominada Metodologia ou Parte Experimental. Como diz o próprio nome, esta é a seção do texto na qual são apresentados os materiais utilizados, bem como os procedimentos realizados nos experimentos. Trabalhos longos podem ter subdivisões desta seção, a fim de tornar sua descrição mais clara e mais organizada.

A finalidade das informações expressas em Materiais e Métodos é proporcionar ao leitor a capacidade de julgar e reproduzir o trabalho desenvolvido, se assim o desejar - é o princípio da reprodutibilidade. Isto não é tarefa fácil por dois motivos principais: o que pode ser óbvio para o autor, pode ser bastante confuso para o leitor; as limitações de espaço podem obrigar o autor a resumir seu texto, o que pode levar à remoção de informações importantes.

É bastante comum a citação, no início da seção, dos principais reagentes utilizados, acompanhados de sua origem. Recomenda-se ainda escrever as fórmulas Químicas dos compostos em detrimento ao seu nome por extenso. No entanto, convém escrever na primeira vez em que a fórmula Química de um dado composto aparece no texto seu nome, sobretudo se a fórmula for de composto complexo e pouco conhecido.

Com relação às soluções utilizadas nos experimentos não há necessidade de descrever minuciosamente seu preparo; basta sempre citar suas concentrações e, neste caso, adotar as medidas internacionalmente aceitas. Quando se trata de soluções que exigem procedimentos especiais é preferível descrever seu preparo. Ressalte-se ainda a importância de alertar o leitor, durante a descrição dos experimentos, quando do uso de reagentes ou produção de substâncias explosivas ou, de alguma forma, danosos à saúde.

Com exceção de equipamentos rotineiros de laboratório como balança ou estufa, os equipamentos utilizados são também citados acompanhados de informações sobre seu modelo e procedência. Veja o exemplo a seguir:

Os pontos de fusão foram medidos através dos aparelhos modelo Q.340.23-Quimis e modelo MQAPF-301-MicroQuímica [...] Os espectros de RMN foram obtidos em um aparelho Unity Plus $-300 \mathrm{MHz}-$ Varian. (Química Nova, v.27, n.6, 905-910, 2004) 
Escrever os procedimentos experimentais realizados na seqüência cronológica na qual eles realmente ocorreram é regra básica para construção de uma clara e objetiva seção Materiais e Métodos. Isto facilita ao leitor compreender o traçado lógico da pesquisa realizada e não imaginar que o trabalho é apenas um relato de vários experimentos desenvolvidos aleatoriamente, sem planejamento e sem uma ligação íntima entre os resultados apresentados.

Observe no exemplo a seguir algumas características presentes na descrição de experimentos:

\section{- autor fornece informações exatas sobre os tipos de reagentes utilizados, as concentrações, o tempo de cada etapa experimental (para permitir a reprodutibilidade)}

Uma solução de $20 \mathrm{~g}$ (262,78 mmoles) de tiouréia, 24,8 g (262,43 mmoles) de ádico monocloroacético em $200 \mathrm{~mL}$ de água destilada, foi deixada sob agitação e refluxo por $18 \mathrm{~h}$. Após completada a reação, a mistura foi deixada em geladeira por $24 \mathrm{~h}$. A reação foi acompanhada por $\mathrm{CCD}$ em sílica (eluente $\mathrm{CHCl}_{3} / \mathrm{MeOH}(9,2: 0,8)$ ). Em seguida, o produto obtido foi filtrado e purificado por sucessivas recristalizações... (Química Nova, v. 27, n. 6, 905p10, 2004)

os procédimentos experimentais foram descritos na ordem em que foram realizados

procedimentos rotineiros (agitação, refluxo, filtração) e técnicas bastante conhecidas (CCD - Cromatografia em Camada Delgada) foram apenas citados

Técnicas rotineiras ou métodos bastante conhecidos não carecem de maiores detalhamentos. Neste caso, citam-se brevemente as técnicas aplicadas e indicam-se referências a seu respeito. As modificações realizadas no método também devem ser mencionadas, caso seja um fator de relevância para o resultado do trabalho. Por fim, se o trabalho utilizou uma técnica inédita esta dever ser minuciosamente descrita.

Cada trabalho tem suas particularidades, o que torna difícil relatar que cuidados devem ser tomados na elaboração desta seção. No entanto, na área de Química, alguns aspectos que não podem deixar de ser mencionados. Assim, convém verificar se as seguintes perguntas encontram respostas na seção Materiais e Métodos:

- Como foram coletadas as amostras? Quantas? Onde? Como foram armazenadas? Quais tratamentos receberam?

- Quantos experimentos foram realizados? Foram feitas análises em duplicata, triplicata?

- Quais técnicas foram empregadas? Quais as condições experimentais $(\mathrm{pH}$, temperatura, concentração)? Foram realizadas algumas modificações?

- Foram realizados tratamentos estatísticos? Quais? 


\subsection{RESULTADOS}

Nesta seção são apresentados todos os achados da pesquisa sem qualquer comentário ou interpretação. Este componente do trabalho merece também extremo cuidado em sua forma de apresentação, pois alguns dados aparentemente óbvios para o autor podem deixar de ser relatados e comprometem a interpretação e reprodução do trabalho.

A imparcialidade do autor também é importante na elaboração da seção de Resultados. Ou seja, o autor deve apenas relatar de forma clara e objetiva os resultados sem deixar transparecer qualquer tendenciosidade a favor ou contra algum resultado.

Pode haver ou não necessidade de descrever todos os dados obtidos no trabalho. Em artigos científicos, por exemplo, o autor deve apresentar apenas os dados mais relevantes diante da totalidade de dados coletados na pesquisa. No outro extremo, temos, por exemplo, os relatórios de laboratório, nos quais são descritos os diversos resultados obtidos, até mesmo os resultados parciais ou incompletos.

Observe no exemplo abaixo que o autor descreve no texto apenas os resultados mais significativos do trabalho:

Observa-se a predominância de ésteres etílicos de ácidos graxos insaturados, com o ácido linoléico aparecendo em maior quantidade, e um teor total de 14,83\% de ésteres etílicos de ácidos graxos saturados presentes no biodiesel produzido a partir do óleo neutro de soja.

(Quimica Nova, v.28, n.1, p. 19-23, 2005)

Para facilitar a compreensão do trabalho como um todo é recomendável que os resultados sejam apresentados em seqüência similar à que foi utilizada na seção, Materiais e Métodos. Da mesma forma que em Materiais e Métodos, se o trabalho for composto por muitos resultados, obtidos de diferentes experimentos, esta seção pode ser apresentada em subtópicos.

Dados numéricos ficam mais organizados se apresentados em tabelas ou gráficos. Além disso, os resultados devem estar providos de informações sobre média, desvio padrão, intervalo de confiança e outros parâmetros estatísticos.

As tabelas e figuras devem apoiar o texto, mas não substituí-lo inteiramente. A mensagem que a tabela ou a figura quer transmitir deve estar descrita no texto. Por outro lado, recomenda-se que as tabelas e figuras, e suas respectivas legendas, sejam autoexplicativas, para que o leitor possa compreender o conteúdo do trabalho sem precisar recorrer ao texto. Deve-se também usar o bom senso quanto à necessidade de apresentar tabelas e gráficos: não é apropriado elaborar uma tabela para apresentar, por exemplo, pequena quantidade de dados ou informações pouco relevantes ou, ainda, acrescentar ao trabalho uma figura que não agregue valor ao texto. Por fim, deve-se evitar colocar a mesma informação tanto em uma tabela quanto em uma figura. 
Tabelas e figuras devem ser enumeradas seqüencialmente de maneira independente entre si e devem, sempre que possível, ser apresentadas o mais próximo de sua citação no texto. Elas são citadas no texto entre parênteses (quando não fazem parte da sentença) ou sem parênteses quando fazem parte da sentença. Observe o exemplo abaixo:

Outros tipos de polímeros encontrados correspondem a apenas 11\% do total (Figura 1). [...] O esquema da Figura 3 mostra como é possível fazer a separação dos resíduos poliméricos... (Quimica Nova, v.28, n.1, 65-72, 2005)

Muitos dos resultados de pesquisa são apresentados na forma de tabela e/ou gráficos, embora, eventualmente, estes possam eventualmente estar presentes em outras seções do trabalho. A seguir são descritas algumas recomendações para sua elaboração.

\subsubsection{APRESENTAÇÃO DE TABELAS}

O IBGE (Instituto Brasileiro de Geografia e Estatística, 1993) estabeleceu algumas normas para elaboração de tabelas, tomadas como base neste trabalho.

As tabelas apresentam diversos componentes e alguns são demonstrados no exemplo, adaptado de artigo de revista Química Nova, exposto a seguir:

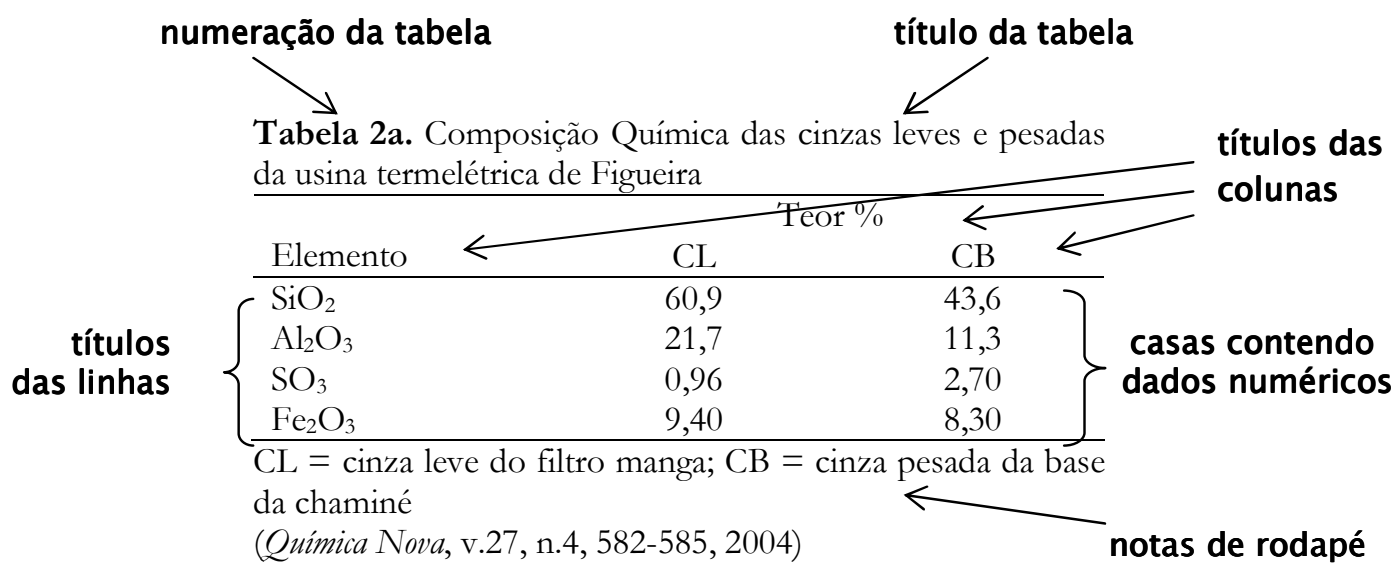

a) Numeração e títulos das tabelas

As tabelas são numeradas em ordem seqüencial crescente, em algarismos arábicos, independente da numeração de figuras.

A legenda ou título da tabela é componente obrigatório no qual são descritas informações necessárias para a compreensão do conteúdo da tabela. No título da legenda deve ser escrita inicialmente a palavra Tabela, apenas com a inicial maiúscula, seguida de sua numeração. A fonte pode ser normal, em negrito ou em itálico e o texto alinhado à esquerda. Sua colocação deve ser acima da tabela. 


\section{b) Título de linhas e colunas}

O significado do conteúdo de cada linha e coluna deve ser indicado na tabela ou complementado em nota de rodapé para não deixar a tabela com muito texto. De modo geral, as colunas apresentadas em trabalhos científicos apresentam poucos traços separando os títulos e dados de linhas e colunas. Assim, na maioria dos casos, apenas três traços são suficientes: (1) uma linha horizontal superior, no início da tabela; (2) uma linha horizontal separando os títulos das colunas dos títulos e dados apresentados nas linhas abaixo; (3) e uma linha horizontal inferior, ao final da tabela. Linhas verticais geralmente são evitadas.

Deve-se evitar construir tabelas excessivamente largas (com muitos dados na horizontal). É preferível apresentar os dados na vertical, tornando sua leitura mais agradável. Uma tabela muito longa pode, se necessário, ser dividida em duas menores colocadas lado a lado, ou ainda ser "deitada" na página (orientação do texto em retrato), cuja legenda deve ser colocada na margem à esquerda.

Em teses, dissertações e relatórios de pesquisa pode ser necessária a apresentação de grande quantidade de dados. Quando, nestes casos, uma tabela ocupar mais de uma página, escreve-se no final da primeira página da tabela "continua”, nas outras páginas "continuação" e ao final da tabela "conclusão". Além disso, no final da primeira página da tabela não se coloca a linha de fechamento horizontal e nas demais páginas o título das colunas deve ser novamente apresentado.

As notas de rodapé em tabelas, embora sejam opcionais, têm diversas utilidades. No exemplo apresentado anteriormente, a nota de rodapé foi utilizada para explicar abreviaturas usadas no título das colunas. Em outros casos podem ser utilizadas também para explicar unidades de medidas ou para indicar a fonte dos dados, caso eles não pertençam ao autor. Símbolos ou letras também podem ser utilizados para apresentação das notas de rodapé em tabelas. Se na tabela existirem muitos algarismos, para não haver confusão, é recomendável evitar fazer as chamadas através de números.

A nota de rodapé da Tabela 2a, anteriormente apresentada, poderia ser colocada da maneira a seguir:

Tabela 2b. Composição Química das cinzas leves e pesadas da usina termelétrica de Figueira

\begin{tabular}{lcc}
\hline & \multicolumn{3}{c}{ Teor $\%$} & $C B *$ \\
\hline $\mathrm{SiO}_{2}$ & 60,9 & 43,6 \\
$\mathrm{Al}_{2} \mathrm{O}_{3}$ & 21,7 & 11,3 \\
$\mathrm{SO}_{3}$ & 0,96 & 2,70 \\
$\mathrm{Fe}_{2} \mathrm{O}_{3}$ & 9,40 & 8,30 \\
\hline * cinza leve do filtro manga; & ** cinza pesada da base da chaminé
\end{tabular}




\subsubsection{APRESENTAÇÃO DE FIGURAS}

Denominam-se figuras em textos científicos uma variedade muito grande de imagens, tais como fotografias, gráficos, esquemas, mapas, fluxogramas e quadros. Geralmente, nas publicações, sobretudo em periódicos, é recomendado que o número de figuras seja limitado ao estritamente necessário. Portanto, o autor deve selecionar apenas as imagens mais significativas do trabalho.

Embora as figuras estejam mais presentes na seção de Resultados, é possível utilizá-las como recurso valioso em seções como Materiais e Métodos, para mostrar equipamentos ou para esquematizar uma técnica ou experimento.

\section{a) Numeração e legendas das figuras}

Todos os tipos de imagens apresentadas no texto são numerados seqüencialmente em números arábicos. Portanto, não se separa a numeração de desenhos, gráficos, fluxogramas, fotografias etc.

As legendas são colocadas logo abaixo da figura. Elas devem conter informações suficientes para que o leitor possa compreender seu conteúdo sem precisar recorrer ao texto. Para que o leitor possa entender a figura, algumas imagens necessitam de informações como, por exemplo, a técnica utilizada, o número de vezes que a imagem foi ampliada, o tipo de coloração empregada etc. Todas estas informações também devem ser expressas na legenda.

Outra utilidade da legenda é citar a fonte da figura quando for de outro autor ou até mesmo do próprio autor, porém já publicada em outro local. Quando não for feita menção, subtende-se que a figura foi idealizada ou produzida pelo autor do texto e publicada pela primeira vez.

Símbolos e abreviaturas que estejam presentes nas figuras devem ter seus significados expressos na legenda. A apresentação de imagens às vezes necessita de recursos para que o autor chame a atenção do leitor para detalhes considerados importantes, que, freqüentemente, são percebidos apenas por quem entende muito do assunto. Uma das formas de conseguir isto é acrescentar, à imagem, letras ou símbolos (asteriscos, estrelas ou setas) ou figuras geométricas (linhas, círculos ou retângulos) à imagem. Obviamente, tanto letras como setas e símbolos devem ter tamanho capaz de chamar a atenção do leitor, sem atrapalhar a visualização da figura. Além disso, deve sempre ser colocada em contraste com o fundo. Ou seja, se a imagem for escura, o fundo deve ser branco.

$\mathrm{Na}$ figura abaixo o autor acrescenta à imagem a indicação do seu tamanho real (os traços em branco têm 1,0 $\mu \mathrm{m}$ de comprimento). 


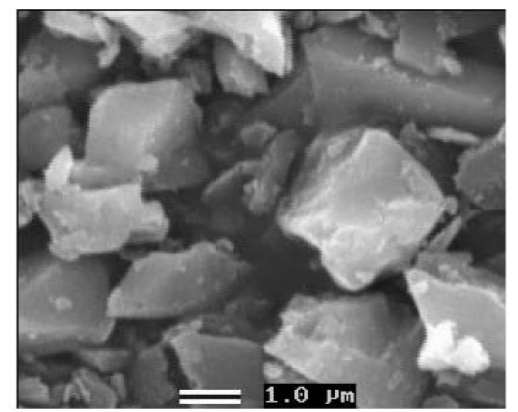

Figura 1. Imagem por microscópio eletrônico de varredura de grãos da fração magnética separada da amostra da rocha.

(Quimica Nova, v. 28, n.1, 5-9, 2005)

\section{b) Apresentação de gráficos}

Os gráficos estão presentes com bastante freqüência nos trabalhos de Química; por isso merecem especial atenção. Eles são representação figurada de uma relação entre grandezas e parâmetros. Os principais tipos de gráficos são os gráficos em barras e os gráficos em pontos e linhas (curvas), cujos componentes serão descritos nos exemplos a seguir.

Observe o exemplo de um gráfico de barras:

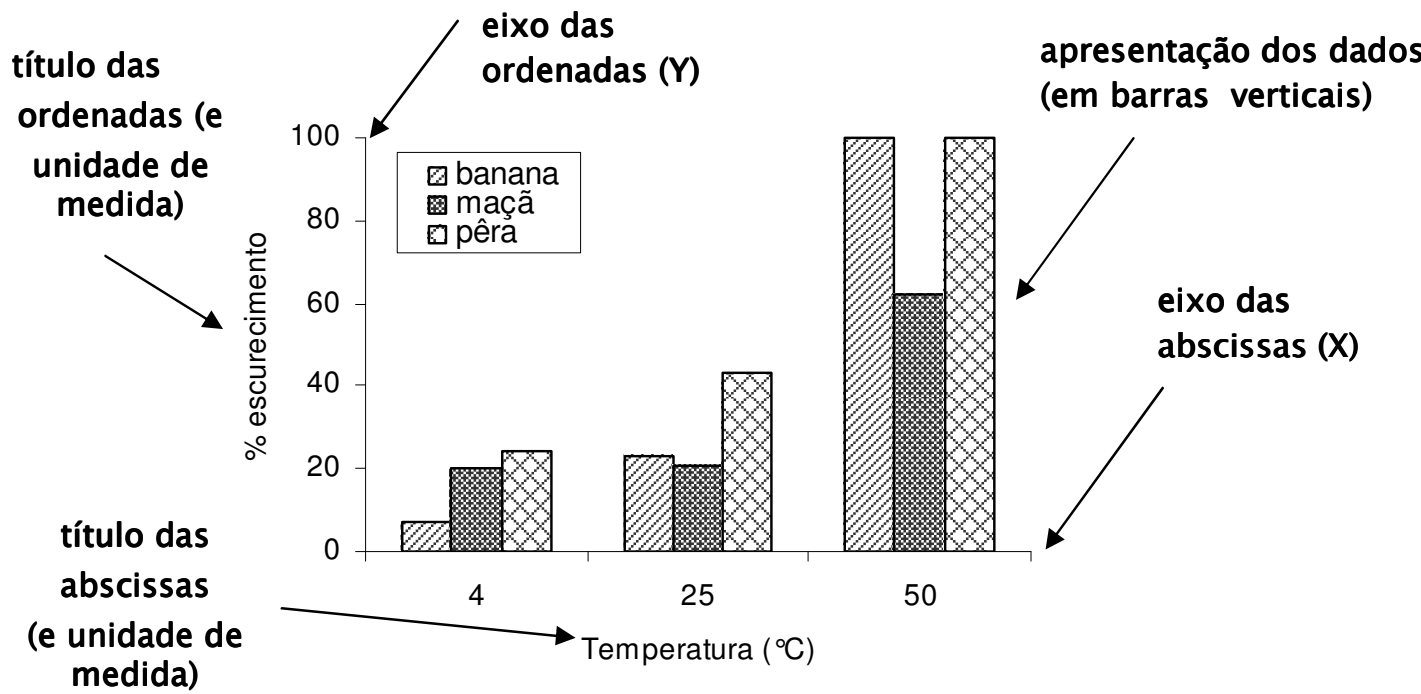

Figura 4. Estudo do efeito da temperatura de 4,25 e $50{ }^{\circ} \mathrm{C}$ na oxidação dos tecidos de banana, maçã e pêra.

(Adaptado de: Química Nova, v. 28, n.3, 548-554, 2005)

Nestes tipos de gráficos as barras podem ser dispostas na horizontal, sobretudo se forem bastante longas.

Os gráficos de pontos e/ou linhas são mais utilizados quando há duas ou mais variáveis interdependentes. A seguir um exemplo de gráfico de linhas e pontos: 


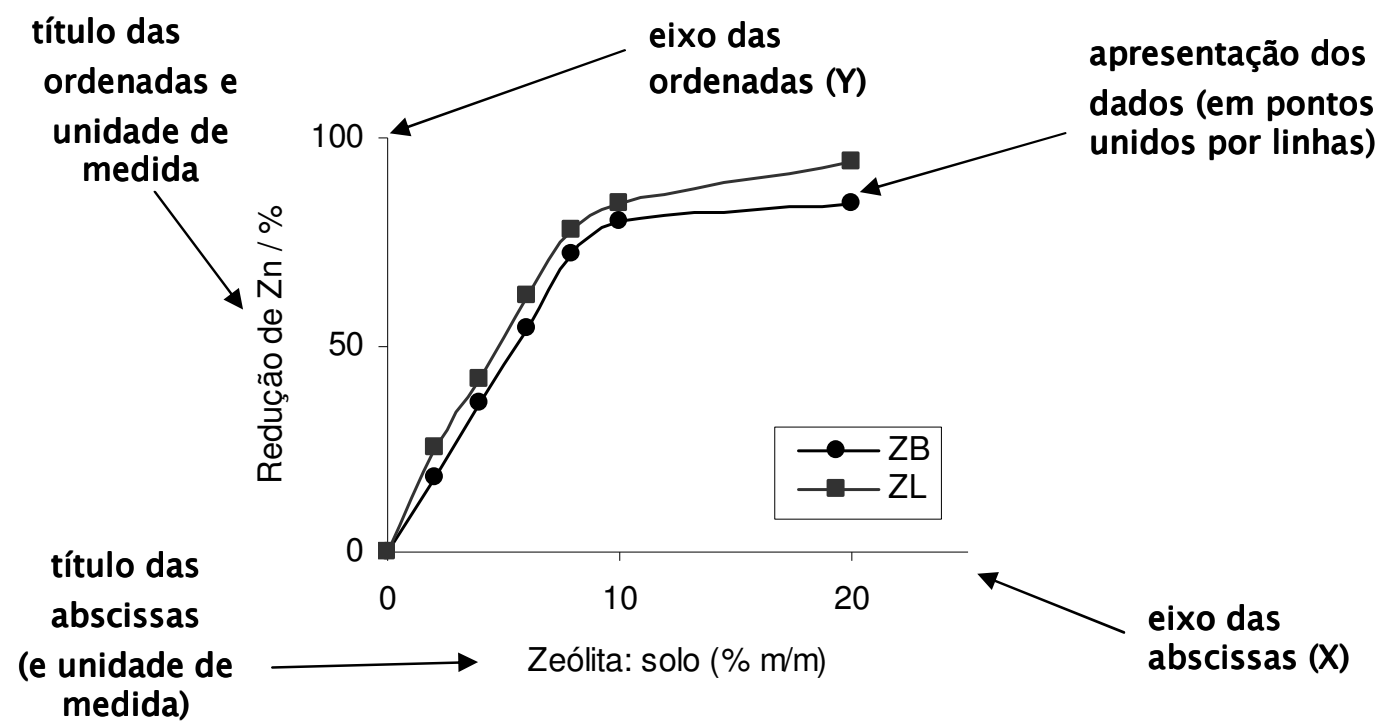

Figura 3. Redução da concentração de Zn no lixiviado de solo em função do teor de zeólita preparada com cinza pesada da base da chaminé (ZB) e com cinza leve do filtro de manga (ZL).

(Adaptado de: Química Nova, v. 27, n.4, 582-585, 2004)

De acordo com os exemplos até aqui citados, percebe-se que alguns componentes são fundamentais para a compreensão dos dados expostos na forma de um gráfico. São eles:

- O significado de cada eixo, bem como, se for o caso, suas respectivas medidas.

- A descrição da seqüência de dados - nos exemplos descritos, cada barra ou a seqüência de pontos - que podem ser apresentadas na legenda interna do gráfico ou na legenda do texto.

- Apresentação das unidades utilizadas no gráfico.

Tanto gráficos em barras quantos em linhas e pontos podem apresentar tratamento estatístico - recurso disponível em vários programas de computador específicos. $\mathrm{Na}$ área de Química um dos mais comuns é o Origin ${ }^{\circledR}$.

\subsection{DISCUSSÃO}

É a seção do texto científico na qual os resultados obtidos são analisados e discutidos de acordo com o que foi proposto e também de acordo com outros trabalhos já publicados referentes ao assunto em questão. Em alguns trabalhos é comum encontramos as seções Resultados e Discussão juntas em uma única seção, como por exemplo nos trabalhos apresentados na revista Quimica Nova. 
As características específicas de cada trabalho tornam os cuidados na elaboração de sua discussão bastante particulares. Assim, embora não seja possível estabelecer uma regra geral para elaboração desta seção, na área de Química, alguns pontos costumam estar presentes com bastante freqüência nas discussões dos trabalhos científicos. Desta forma, convém verificar se as seguintes perguntas encontram respostas na seção Discussão:

- A questão ou proposta inicial do trabalho foi respondida? Total ou parcialmente?

- Quais as semelhanças e diferenças do presente trabalho com os resultados apresentados por outros autores? É possível explicar o motivo dessas semelhanças e diferenças?

- É possível nova interpretação dos resultados obtidos no trabalho?

- Qual a importância dos resultados diante do problema apresentado? Quais as principais conclusões do trabalho?

$\mathrm{Na}$ discussão também pode ser apresentado um resumo dos principais resultados, geralmente descrito logo nas primeiras linhas desta seção. Às vezes durante a discussão torna-se necessário reapresentar alguns dados para auxiliar nas argumentações. No entanto, deve-se tomar cuidado para que não se ocupe grande parte do texto apenas relatando novamente os resultados. Em alguns casos também pode ser necessário discutir a metodologia utilizada, sobretudo se foram realizadas modificações que permitiram alterações significativas nos resultados.

Da mesma forma, deve-se evitar apresentar uma longa lista de resultados encontrados por outros autores sem interpretar as semelhanças e diferenças entre eles e o trabalho em questão. É importante ainda ter bastante cuidado na redação do texto para não confundir o leitor sobre quais são os resultados do trabalho e quais são os de outros autores, sem deixar claro a autoria das interpretações e opiniões de um trabalho citado.

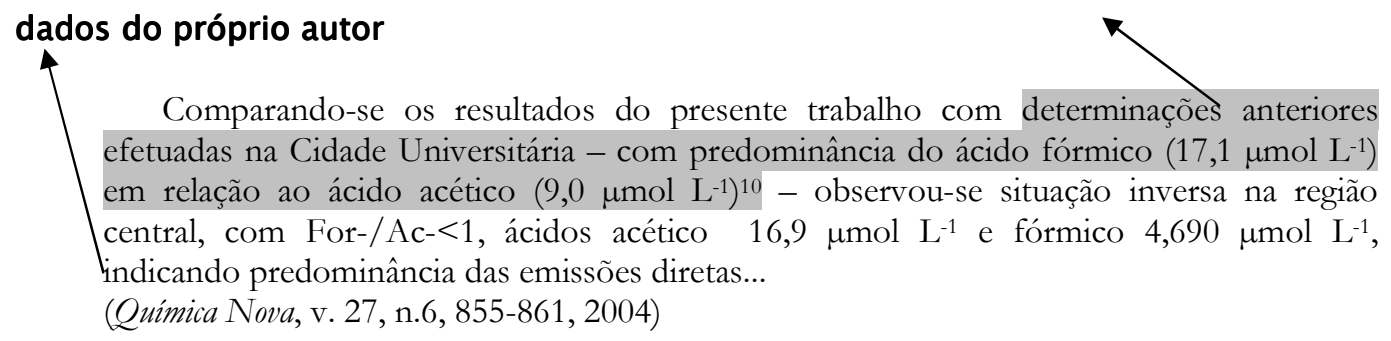

Em muitas discussões também são observadas sugestões do autor para trabalhos futuros, principalmente se as questões levantadas no início do trabalho não foram totalmente respondidas ou se os resultados levaram a novos questionamentos. 
indicação de possíveis trabalhos futuros

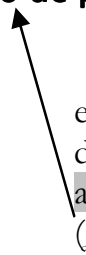

As considerações acima, embora pertinentes, não permitem apontar o mecanismo exato através do qual os compostos exercem sua atividade antiedematogênica neste modelo de inflamação, no entanto indicam uma perspectiva de estudos posteriores para o aprofundamento acerca do mecanismo de ação dos mesmos. (Química Nova, v. 27, n.6, 905-910, 2004)

\subsection{CONCLUSÕES}

A apresentação das conclusões de um trabalho em seção separada no texto científico ocorre com mais freqüência em trabalhos acadêmicos como monografias, teses e relatórios. Portanto, nem todos os trabalhos científicos apresentam a seção Conclusão ou Conclusões. Em artigos, por exemplo, geralmente as conclusões são expostas no decorrer da discussão e, às vezes, relembradas resumidamente ao final do texto.

Ao elaborar a Conclusão é preciso ser bastante objetivo, descrever apenas as principais conclusões e evitar enumerar novamente todos os resultados obtidos ou citar resultados e conclusões de outros autores.

\subsection{CITAÇÕES E REFERÊNCIAS BIBLIOGRÁFICAS}

$\mathrm{Na}$ elaboração de um texto científico, o autor costuma apoiar-se nas idéias e resultados apresentados por outros autores. Um cientista raramente está sozinho na elaboração de novos conhecimentos. Faz-se necessário tomar por base o conhecimento já existente. As inúmeras citações e referências bibliográficas - característica inerente ao trabalho científico - são reflexo disso.

As referências e citações bibliográficas têm especial importância por vários motivos: por uma questão de ética deve-se sempre citar o autor responsável por uma dada informação que não seja sua. Por respeito ao leitor sempre deve ser dado o caminho para a busca de um trabalho original completo cuja parte foi citada no seu texto; para resguardar-se da responsabilidade de fornecer informações incorretas deve-se sempre citar a fonte de todos os dados ou informações não oriundas do seu trabalho.

Embora muitas instituições ou revistas tenham normas específicas para apresentação das citações e referências bibliográficas, trataremos a seguir das formas mais freqüentemente utilizadas para fazê-las. A ABNT (Associação Brasileira de Normas Técnicas) apresenta normas mais completas que tratam desse assunto, como a NBR 10520/2002 e a NBR 6023/2002, respectivamente, sobre citações em documentos e sobre referências.

\subsubsection{CITAÇÕES}


As citações são os registros no decorrer do texto de todas as informações emitidas por outro autor ou oriundas de outras fontes. Existem duas formas de citações: a direta e a indireta.

A citação direta ocorre quando no texto são citados orações ou períodos iguais ao do trabalho do qual foram extraídos. Neste caso, as citações devem ser colocadas entre aspas. Quando forem frases longas, a citação é feita em bloco e apresentada em parágrafo isolado, com letras menores que a do texto, em espaço simples, sem aspas e margem recuada a quatro centímetros da margem esquerda.

O exemplo a seguir mostra uma citação direta, apresentada no corpo do texto (entre aspas).

Segundo $\mathrm{EPA}^{4}$, um pesticida "é qualquer substância ou mistura de substâncias com capacidade de prevenir, destruir, repelir ou atenuar qualquer peste".

(Adaptado de: Química Nova, v. 27, n.5, 720-724, 2004)

A seguir apresentamos exemplo de uma citação direta, apresentada em bloco (fonte menor e recuada a quatro centímetros da margem esquerda).

\footnotetext{
Medições em análises químicas, quer sejam para o controle da qualidade de processos e produtos ou destinados ao acompanhamento de trabalhos de pesquisa e desenvolvimento, quando consideradas erradas ou não suficientemente confiáveis, podem representar desperdício de tempo e dinheiro.

(Química Nova, v. 27, n. 6, p. 993-1003, 2004)
}

Quando, por outro lado, o autor apresenta com suas próprias palavras dados ou informações de outro autor a citação é considerada indireta. A citação poderá ser feita por dois sistemas diferentes, dependendo do formato exigido para o trabalho em questão.

\section{a) Sistema de citação autor-data}

Também chamado sistema alfabético, no sistema autor-data a citação é apresentada com o sobrenome do autor, seguido pelo ano de publicação.

Quando os nomes dos autores fazem parte da sentença, apenas o ano de publicação fica entre parênteses e o nome do autor é escrito com inicial maiúscula. Quando não fazem parte do texto, ambos são colocados entre parênteses separados por uma vírgula e o nome do autor é escrito em caixa alta (todas maiúsculas).

Quando forem dois autores, ambos são citados separados por "e" fora do parênteses e por ponto e vírgula (;) quando dentro do parênteses. Se forem três autores, estes são separados por ponto e vírgula dentro do parênteses e, quando fazem parte do texto, por vírgula entre os dois primeiros autores e "e" entre os dois últimos. Quando for citado um trabalho com três ou mais autores, deve aparecer no texto apenas o nome do primeiro seguido pela expressão latina “et al." (e outros). É possível também ser observado em alguns trabalhos a expressão "e colaboradores" em substituição ao "et al.". 
Em todos os casos, quando se utiliza este formato de citação autor-data, a lista de referências bibliográficas apresentada no final do capítulo é organizada em ordem alfabética.

Observe os exemplos:

\section{citação de trabalho com mais de três autores na própria sentença}

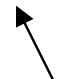

Monyem e Vangespen (2001) também observaram que a performance do motor com biodiesel puro e suas misturas [...]

Dorado et al. (2002) concluíram que o motor a diesel, analisado sem nenhuma modificação, funciona de maneira bem sucedida com misturas [...]

O número de cetano representa uma das mais importantes propriedades do diesel automotivo...(SERDARI et al., 1999) [...]

O Brasil consome cerca de 35 milhões de t/ano de óleo diesel (RODRIGUES, 2001)...(Adaptado de: Química Nova, v.28, n.1, 19-23, 2005).

citação de trabalho com mais de três

citação de um autor fora da sentença autores fora da sentença

Citações de vários trabalhos em uma mesma sentença devem ser apresentadas em ordem alfabética ou ordem cronológica, segundo alguns editores, e separadas por ponto e vírgula. E quando forem trabalhos diferentes de um mesmo autor, eles são citados em ordem cronológica.

A extração torna-se eficiente quando a agitação é utilizada para facilitar o transporte de massa entre a fase aquosa e a fibra (PAWLISZYN, 1997; DUGAY et al., 1998; WERCINSKI, 1999).

(Adaptado de :Química Nova, v. 27, n. 5, 781-789, 2004)

Se forem citados trabalhos diferentes de um mesmo autor e do mesmo ano, podese acrescentar letras ( $a, b, c)$ após o ano para diferenciá-los e citá-los da mesma forma na lista de referências bibliográficas, conforme demonstra o exemplo abaixo:

Por outro lado o fato de não existir uma enzima universal faz com que a metodologia não seja geral ou aplicável a qualquer seqüência peptídica (BORDUSA, 2002a; LIRIA et al., 2002). [...] Por esta razão, para maximizar os rendimentos de síntese recomenda-se:.utilizar substratos miméticos (BORDUSA 2002b; IVANOV et al., 1997).

\section{REFERÊNCIAS}

BORDUSA, F.; Chem Rev. 2002a, 102, 4817.

BORDUSA, F.; Curr. Protein Pept. Sci. 2002b, 2, 159.

(Adaptado de: Química Nova, v. 27, n. 5, 781-789, 2004) 


\section{b) Sistema de citação numérico}

Neste sistema, os trabalhos citados são numerados seqüencialmente de acordo com a ordem em que surgem no texto. A vantagem desse sistema é tornar a leitura mais fluida e ocupar menos espaço no texto. Por outro lado, o leitor só terá acesso a informações sobre os autores dos trabalhos citados ao consultar a lista de referências bibliográficas no final do trabalho.

Os números, em algarismos arábicos, são apresentados entre parênteses ou colchetes ou exponencialmente. Vários trabalhos podem ser citados em uma mesma sentença. Quando forem apenas dois números, eles são separados por vírgula. Se mais de dois, o primeiro e último aparecem separados por um traço.

citação numérica da referência entre parênteses

\section{citação numérica sobrescrito}

Monyem e Vangespen (14) também observaram que a performance do motor com biodiesel puro e suas misturas [...]. O número de cetano representa uma das mais importantes propriedades do diesel automotivo ${ }^{44}$. [...]

...sua utilização está associada à substituição de combustíveis fósseis em motores do ciclo diesel ${ }^{16,17}$.

Neste contexto, os bleos vegetais aparecem como alternativa para substituição ao óleo diesel em motores de ignição por compressão $\mathrm{O}^{2-4}$

(Adaptado de: Quimica Nova, v.28, n.1, 19-23, 2005).

citação numérica de duas referências

citação de três ou mais referências

A lista de referências bibliográfica, neste caso, deve vir organizada em ordem numérica crescente, de acordo com os trabalhos correspondentes aos números citados no texto.

Não citar autores a partir de seus trabalhos originais, mas a partir de outros autores, pode implicar em passar uma informação que talvez esteja errada ou incompleta. E mais: tais equívocos, caso forem citados por outros leitores de seu trabalho, podem assim perpetuarem-se na literatura. Uma alternativa quando não é possível ter acesso ao trabalho original é a utilização da citação da citação.

O seguinte exemplo:

Os óleos brutos comercialmente encontrados possuem índice de acidez entre 0,5 3\%...(FERRARI et al., 2005).

Pode ser expresso mais claramente da seguinte forma:

Segundo Kusdiana e Saka (citado por FERRARI et al., 2005), os óleos brutos comercialmente encontrados possuem índice de acidez entre $0,5-3 \% \ldots$ 
Observa-se, então, que diante do primeiro exemplo é possível que o leitor considere que os dados apresentados são de autoria original de Ferrari et al., até localizar seu artigo original e descobrir que, na realidade, tais informações foram fornecidas por Kusdiana e Saka. Portanto, a forma mais clara de apresentar a informação ao leitor é fazendo a citação da citação.

O formato de apresentação da citação da citação descrito anteriormente, no entanto, não é o padrão estabelecido pela ABNT. Para citar um texto em que não se teve acesso ao documento original, a ABNT recomenda a utilização da expressão latina apud (citado por), conforme pode ser observado no exemplo a seguir.

\section{nome do autor e ano de publicação do trabalhe não consultado}

Segundo Kusdiana e Saka (2001 apud FERRARI et al., 2005), os óleos brutos comercialmente encontrados possuem índice de acidez entre $0,5-1 \%$... (Quimica Nova, v. 28, n.1, p.19-23, 2005)

nome do autor e ano do trabalho consultado

Neste caso temos duas citações: Kusdiana e Saka (2001), documento original não consultado, cuja referência deve ser colocada em nota de rodapé; e Ferrari et al (2005), obra consultada e referenciada nas Referências Bibliográficas.

\subsubsection{REFERÊNCIAS BIBLIOGRÁFICAS}

Esta é uma das seções de um trabalho científico cujas formas de apresentações são bastante distintas, sobretudo entre os periódicos. Cada um tem suas próprias "normas para apresentação de trabalhos" e, desta maneira, cabe ao autor adequar-se às mesmas. Os trabalhos acadêmicos costumam, no entanto, seguir as normas da ABNT.

Segundo a NBR 6023/2002, todas as referências são alinhadas à esquerda, com espaço simples entre linhas e espaço duplo entre parágrafos. A seguir são descritas resumidamente as formas de elaboração de referências dos principais tipos de trabalhos utilizados na área de Química.

\section{a) Artigos em periódicos}

AUTOR(ES) DO ARTIGO. Título do artigo. Nome da revista (itálico ou negrito), local, volume, número, páginas inicial-final, mês, ano.

MORAES, S.L.; LANDGRAF, M.D.; REZENDE, M.O.O. Caracterização de ácidos húmicos de diferentes origens por eletroforese capilar de zona. Eclética Química, São Paulo, v.29, n.2, p.47-52, jul. 2004.

b) Livros (em um todo) 
SOBRENOME, Nome. Título (negrito ou itálico): subtítulo (se houver). Tradutor (se houver). Edição. Local: Editora, ano, número de páginas.

FARIAS, Robson Fernandes. Para gostar de ler a história da Química. 1.ed. Campinas: Editora Átomo, 2003, 98p.

c) Capítulos de livros

AUTOR DO CAPÍTULO, Nome. Título do capítulo. In: AUTOR DO LIVRO, Nome. Título do livro. Edição. Local: Editora, ano, pág. inicial final.

ARGUMEDO, Manuel Alberto. Em busca de uma metodologia de ação institucional. In: BRANDÃO, Carlos Rodrigues. Repensando a Pesquisa Participante.3.ed. São Paulo: Brasiliense, 1999, p.189-222.

\section{d) Trabalhos apresentados em congressos}

AUTOR(ES) DO TRABALHO. Título. In: NOME DO CONGRESSO, número do evento, ano, local de realização., Título da publicação (Anais, Resumos, seguido de reticências para não repetir o nome do evento, negrito ou itálico). Local: Editora, data, pág do trabalho.

OLIVEIRA, J. R. S.; FRANCISCO, C. A.; QUEIROZ, S. L. Uma revisão das propostas para o desenvolvimento de habilidades de expressão oral e escrita de alunos de graduação em Química. In: REUNIÃO ANUAL DA SOCIEDADE BRASILEIRA DE QUÍMICA, 28, 2005, Poços de Caldas-MG. Livro de resumos... São Paulo: Sociedade Brasileira de Química, 2005, ref ED-129.

e) Dissertações e teses

SOBRENOME, Nome do autor. Título do trabalho (negrito ou itálico). Ano. Número de folhas. Categoria do trabalho (Área de concentração) - Nome da instituição, Local, ano de publicação.

RIGOLI, Isabel Cristina. Polimerização de monômeros vinílicos fotoiniciada por Ru(II) e Fe(III). 2005. 144f. Tese (Doutorado em Físico-Química) - Instituto de Química de São Carlos, Universidade de São Paulo, São Carlos, 2005.

Convém lembrar que alguns periódicos solicitam que os autores coloquem nas referências bibliográficas o formato abreviado de apresentação dos nomes dos periódicos. Esta abreviação, no entanto, deve seguir os padrões adotados internacionalmente. A lista dos títulos abreviados dos periódicos pode ser encontrada na internet (http://www.cas.org/sent.html).

\subsection{AGRADECIMENTOS}


Embora nem sempre obrigatório, os agradecimentos estão presentes em diversos trabalhos científicos. Em artigos de periódicos são apresentados no final do trabalho, geralmente após a discussão. Em trabalhos acadêmicos, como monografias e teses surgem no início do trabalho, em página separada das demais que compõem o texto.

Nesta parte do texto podem estar presentes:

- Agradecimentos a pessoas que contribuíram de alguma maneira no trabalho, como estudantes, técnicos ou outros colaboradores;

- Agradecimentos a pessoas ou instituições que cederam materiais ou permitiram o uso de equipamentos ou laboratórios;

- Citação de agências que concederam auxílio financeiro para realização da pesquisa, bem como bolsas de estudos para algum dos participantes;

Observe os seguintes exemplos:

Os autores agradecem à FAPESP (processo no $n^{\circ}$ 01/09838-0) e ao MACKPESQUISA pelo auxílio financeiro. Ao Instituto de Tecnologia pra o Desenvolvimento do Paraná - LATEC - pelo empréstimo do coletor de automático de água de chuva.

(Química Nova, v. 27, n.6, 855-861, 2004)

Ao $\mathrm{CNPq}$ pelo apoio concedido e à empresa COINBRA pelo óleo fornecido. (Química Nova, v.28, n.1, 19-23, 2005)

Os autores agradecem ao CNPq pelo auxilio concedido (processo $n^{\circ} 470150 / 01-7$ ) e à Dra M. A. F. Pires pelo uso do CG/MS. E. Komatsu agradece ao CNPq pela bolsa de mestrado concedida.

(Química Nova, v.27, n.5, 720-724, 2004) 


\section{4}

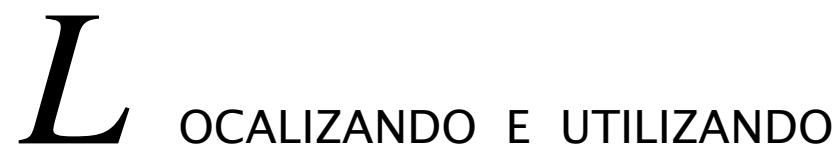

A LITERATURA EM QUÍMICA

Durante a elaboração de um trabalho científico, o autor necessita contextualizar seu problema de pesquisa, conhecer os avanços ocorridos em sua área, pesquisar novas metodologias que sejam adequadas ao seu trabalho, comparar seus resultados com os apresentados por outros autores, discutir pontos relevantes e/ou divergentes. Para realizar essas tarefas, ele toma por base trabalhos já publicados na literatura que versem sobre o tema de seu trabalho. Por esse motivo, todo cientista precisa constantemente consultar a literatura científica, desde a concepção do trabalho até a apresentação de seus resultados.

É necessário, portanto, conhecer como a literatura científica - em particular a de Química - se organiza e como localizá-la.

\subsection{TIPOS DE FONTES DE PESQUISA}

As publicações científicas podem ser originadas de trabalhos que contenham resultados originais de pesquisa ou de trabalhos derivados de repetições, avaliações ou aplicações de informações já publicadas. Por isso, as informações científicas são classificadas em categorias distintas: fontes primárias, fontes secundárias e terciárias.

\subsubsection{FONTES PRIMÁRIAS}

São trabalhos que relatam resultados originais de pesquisa, geralmente direcionados aos pares. Fazem parte das fontes primárias os seguintes documentos científicos:

- Artigos científicos (originais de pesquisa e comunicações curtas)

- Relatórios de pesquisa

- Dissertação de mestrado

- Tese de doutorado

Em diversas publicações científicas é mais freqüente a apresentação de referências bibliográficas contendo em sua maioria fontes primárias. Isso indica que as informações expressas no texto são atuais, originadas de trabalhos originais de pesquisa. Além disso, a 
apresentação de referências provenientes de fontes primárias facilita ao leitor localizar o trabalho original do qual foi extraída determinada informação.

Em Química, cujos trabalhos geralmente são provenientes de pesquisa experimental, a presença, nas publicações, de uma seção de Materiais e Métodos ou da menção da metodologia empregada, pode caracterizar uma fonte primária. Além disso, a seção Resultados, usualmente acompanhada de informações expressas em figuras e tabelas, também faz parte da maioria das fontes primárias.

\subsubsection{FONTES SECUNDÁRIAS}

As fontes secundárias são trabalhos cujo conteúdo é baseado nas pesquisas primárias. $\mathrm{O}$ autor reúne e resume informações publicadas por vários autores sobre um determinado assunto.

As principais fontes secundárias de pesquisa na literatura científica são:

- Artigos de revisão (destinados aos pares)

- Artigos científicos de divulgação (destinados aos pares)

- Artigos de divulgação científica (destinados ao público em geral)

- Livros e materiais didáticos

Leva-se certo tempo (meses ou anos) até que vários resultados de pesquisa original sejam utilizados na produção de uma publicação secundária. Por esse motivo, as fontes secundárias apresentam informações consideradas atrasadas em relação às primárias. Por outro lado, geralmente são informações já consolidadas na literatura. A vantagem das publicações secundárias é fornecer ao leitor uma visão mais abrangente de determinada área ou assunto. Assim, em um único trabalho o leitor pode ter acesso a diversas informações fornecidas por vários autores.

Os trabalhos científicos que fazem parte das fontes secundárias não obedecem a um padrão formal de apresentação, como nas fontes primárias. Sua organização geralmente depende do público ao qual se destina.

\subsubsection{FONTES TERCIÁRIAS}

Algumas fontes bibliográficas são destinadas a publicar resumos de trabalhos já publicados na literatura, tanto de fonte primárias quanto de fontes secundárias. Tais documentos são classificados como fontes terciárias de pesquisa. Assim os indexes e os abstracts são considerados publicações terciárias. Nesta categoria de publicação temos, na área de Química, o Chemical Abstracts.

O Chemical Abstracts é a mais importante obra de referência na área de Química, pois reúne a literatura mundial dessa área, fornecendo informações bibliográficas completas e o resumo dos trabalhos publicados em diversos periódicos. Suas fontes incluem mais de 8000 periódicos, patentes, relatórios técnicos, livros e dissertações 
publicados em vários países. Atualmente o Chemical Abstracs pode ser consultado em sua tradicional versão impressa ou em sua versão eletrônica.

$\mathrm{Na}$ versão impressa, o usuário pode pesquisar trabalhos publicados em determinado ano através de tópicos como, por exemplo, o assunto, o nome do autor, a substância Química ou fórmula molecular. Para realizar essa busca, o usuário identifica primeiramente no índice (index) específico de cada tópico o código de localização no trabalho nos livros do Chemical Abstracts do ano pesquisado. A partir deste código é possível localizar o trabalho desejado. As bibliotecas geralmente dispõem de material educativo que fornece orientações detalhadas de como pesquisar trabalhos no Chemical Abstracts.

Ao contrário da versão impressa, a versão eletrônica do Chemical Abstracs torna esse processo de localização de trabalhos mais fácil e rápida. A versão eletrônica está disponível através do software SciFinder Scholar. Seu acesso, no entanto, é restrito. Ou seja, SiciFinder Scholar pode ser acessado somente através de assinatura regulamentada pelo fornecedor.

\subsection{ALGUMAS BASES DE DADOS EM QUÍMICA}

As bases de dados podem ser classificadas em bases de acesso público e bases de acesso regulamentado. As bases de acesso público podem ser acessadas gratuitamente pela Internet por qualquer usuário em qualquer computador. As bases de acesso regulamentado são aquelas que só estão disponíveis para pesquisa mediante contrato firmado com seus fornecedores.

A seguir são apresentadas algumas das principais bases de dados, de acesso público e regulamentado, utilizadas na área de Química.

\subsubsection{BASES DE DADOS DE ACESSO PÚBLICO}

\section{a) SciELO}

A Scientific Electronic Library Online - SciELO é uma biblioteca eletrônica que abrange uma coleção selecionada de periódicos científicos brasileiros. Estão disponíveis para consulta cerca de 150 periódicos nacionais. Seu acesso é gratuito através do site www.scielo.br. Na área de Química, podem ser localizados os seguintes periódicos: Eclética Quimica, Quimica Nova e Journal of the Brazilian Chemical Society.

A base SciELO proporciona acesso à sua coleção de periódicos através de uma "lista alfabética" de títulos de periódicos, ou por meio de uma "lista de assuntos", ou ainda através de um módulo de "pesquisa de títulos" dos periódicos. 


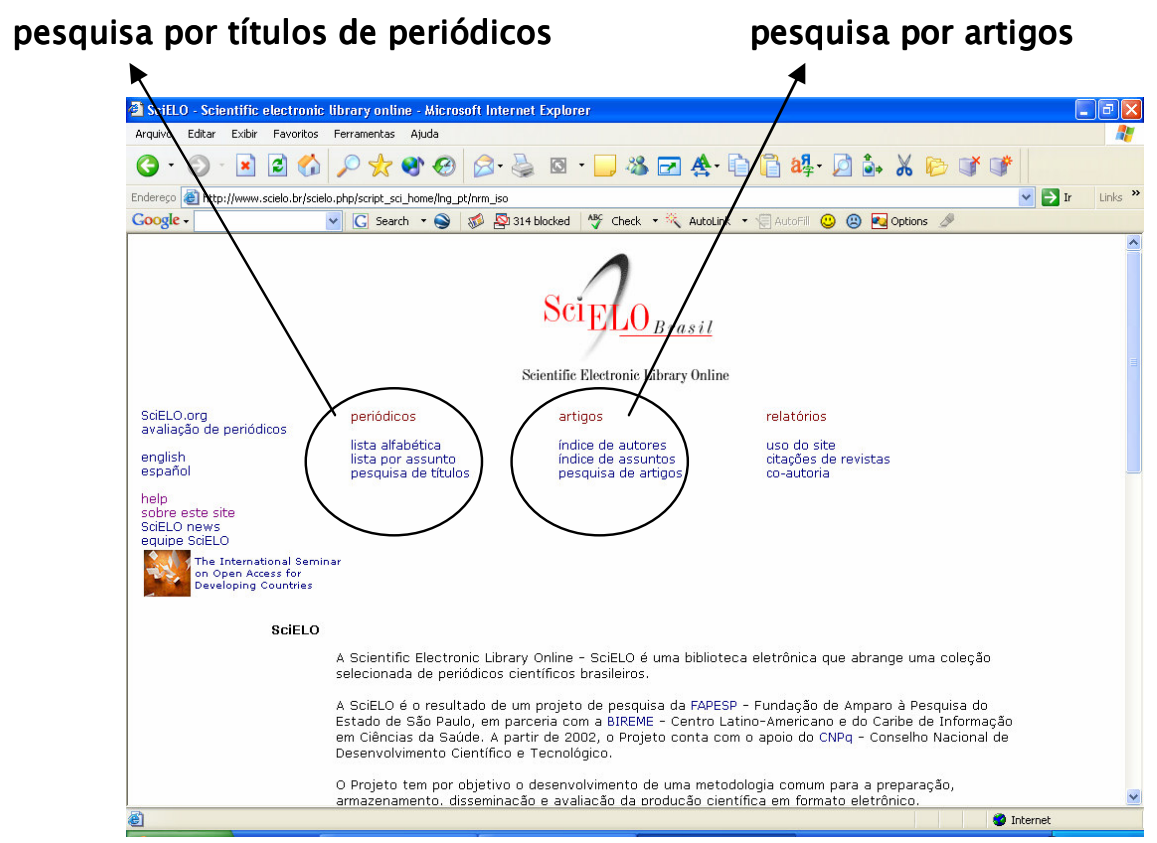

É possível também pesquisar por artigos através de um “índice de autor" e um "índice de assuntos", ou por meio de um formulário de "pesquisa de artigos". A pesquisa por artigos é realizada através de elementos que o compõem, tais como autor, palavras do título, assunto, palavras do texto e ano de publicação.

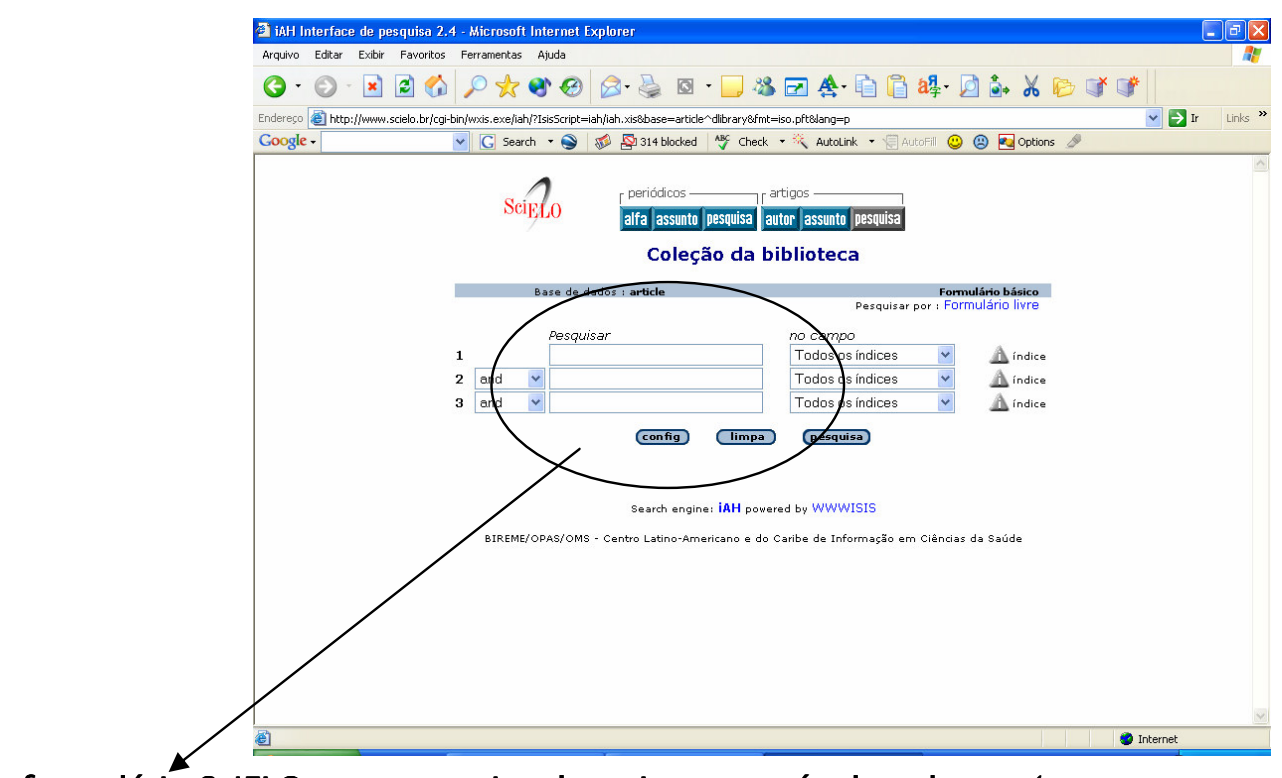

formulário SciELO para pesquisa de artigos através de palavras (assunto, autor, ano, palavras do resumo ou título etc.) 
Embora não específica da área de Química, cabe ainda mencionar a base de dados ERIC (Education Research Information Center), a maior fonte de informação existente na área de educação. Ela contém mais de 950.000 resumos de documentos e artigos de periódicos científicos de prática e pesquisa em educação. $\mathrm{O}$ usuário pode ter acesso livre via Internet através do site www.eric.ed.gov. Nesta base de dados podem ser encontrados periódicos relacionados ao ensino de Química como, por exemplo, o Journal of Chemical Education.

\subsubsection{BASES DE DADOS DE ACESSO REGULAMENTADO}

\section{a) Science Direct}

A base de dados Science Direct, da Editora Elsevier, contém publicações periódicas cobrindo as áreas de Ciências Biológicas, Ciências da Saúde, Ciências Agrárias, Ciências Exatas e da Terra, Engenharias, Ciências Sociais Aplicadas, Ciências Humanas e Letras e Artes. Dispõe de um acervo de 1.700 títulos de periódicos e pode ser localizada em www.sciencedirect.com.

Nesta base, as buscas bibliográficas são realizadas através de palavras (assunto, palavras-chave, palavras do título ou resumo), ou ainda o nome do autor, o título da revista ou ano de publicação. $\mathrm{O}$ usuário também pode restringir suas buscas aos anos desejados, escolher uma área do conhecimento ou ainda especificar o tipo de documento que deseja pesquisar (apenas artigos completos e/ou resumos dos artigos).

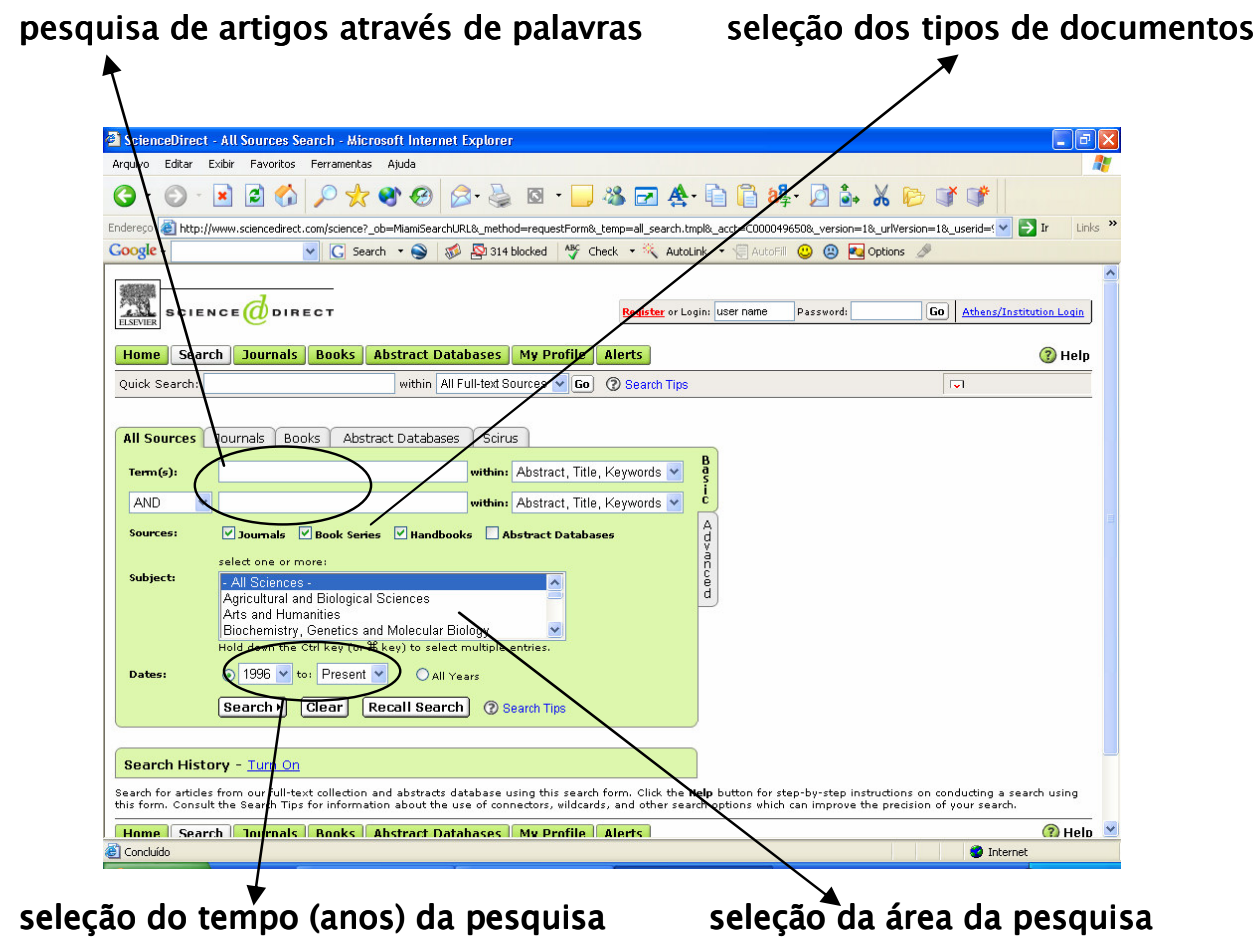


Nesta base de dados os resultados de buscas oferecem opções como o resumo do artigo, o texto completo em PDF ou ainda o texto completo mais links, nos quais o usuário pode localizar o resumo ou até mesmo o texto completo de outros artigos citados pelo artigo então localizado. É possível ainda localizar os trabalhos que citaram o artigo.



resultados de busca bibliográfica, com as opções de visualizar apenas o resumo, o texto completo ou baixar o arquivo em PDF

\section{b) Web of Sicence}

Web of Science é uma base de dados do ISI (Institute for Scientific Information) que permite a localização de trabalhos publicados nos mais importantes periódicos internacionais, apresentando as referências bibliográficas contidas nos mesmos, informando ainda, sobre os trabalhos que os citaram, com referências a outros trabalhos. Compreende: Science Citation Index, Social Citation Index e Arts and Humanities Index.

Após entrar na página do ISI Web of Knowledge, cujo endereço na Internet é http://portal.isiknowledge.com/portal.cgi, o usuário poderá acessar a Web of Science. A base oferece vários recursos de pesquisa, como selecionar o período de pesquisa, realizar buscas através de tópicos como palavras do título, do resumo ou das palavras-chave do trabalho. É possível, também, pesquisar através no nome do autor ou ano de publicação. 


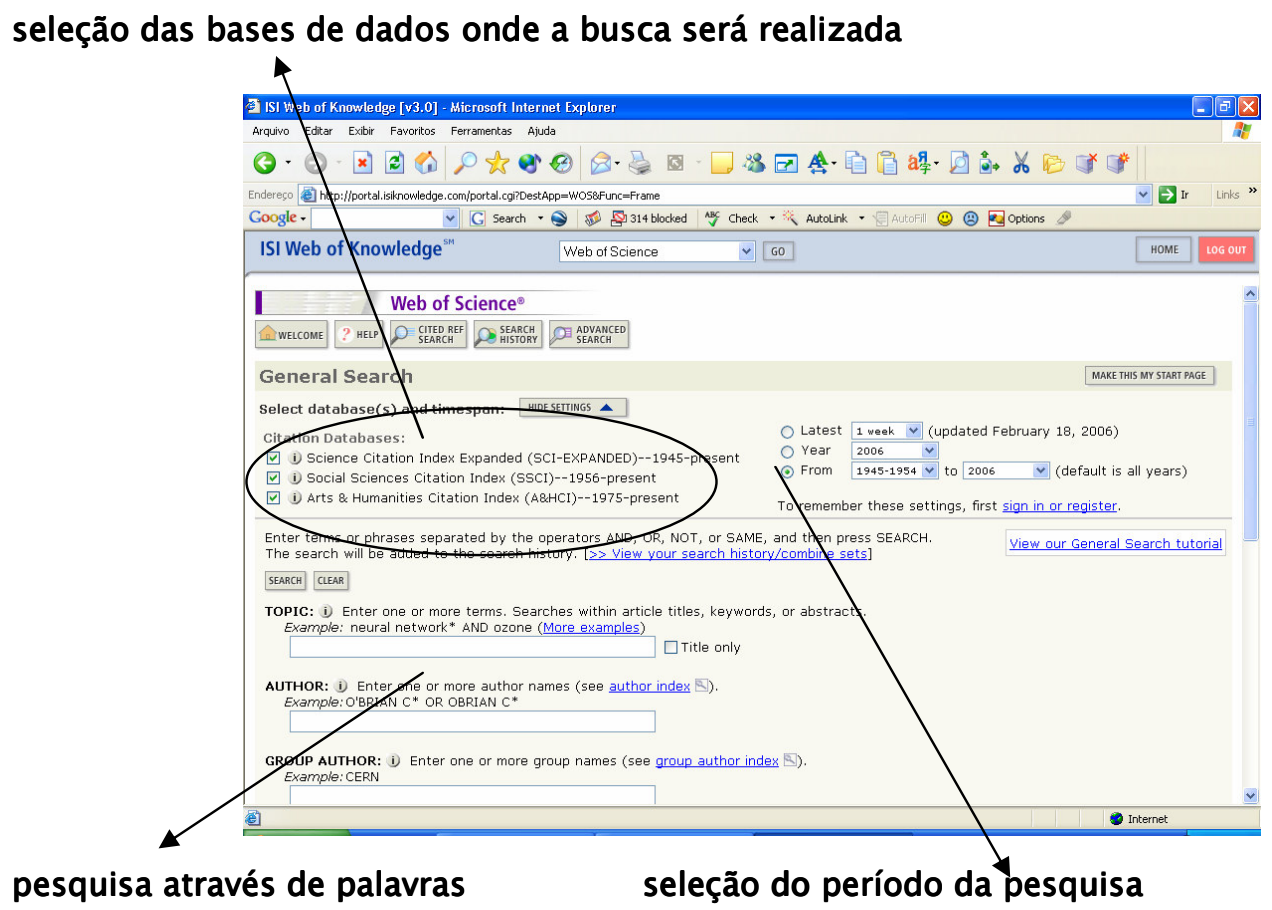

Também publicado pelo ISI e apresentado no ISI Web of Knowledge, o Journal Citation Reports (JCR) oferece recursos para avaliação de títulos de periódicos (fator de impacto, entre outros). O JCR é importante ferramenta auxiliar tanto para o pesquisador, que poderá determinar onde publicar seus trabalhos, como para os bibliotecários que realizam análise de coleção de periódicos.

\section{c) Portal Capes}

O Portal Capes é uma base de dados criada pelo Ministério da Educação para dar suporte às instituições de ensino e pesquisa e aos programas de pós-graduação do Brasil. Seu acesso pode ser realizado através do seguinte endereço na Internet. http://www.periodicos.capes.gov.br/portugues/index.jsp. A base tem cerca de 9.550 títulos de periódicos com textos completos disponíveis para consulta, os quais aumentam anualmente. 
pesquisa através do título do periódico

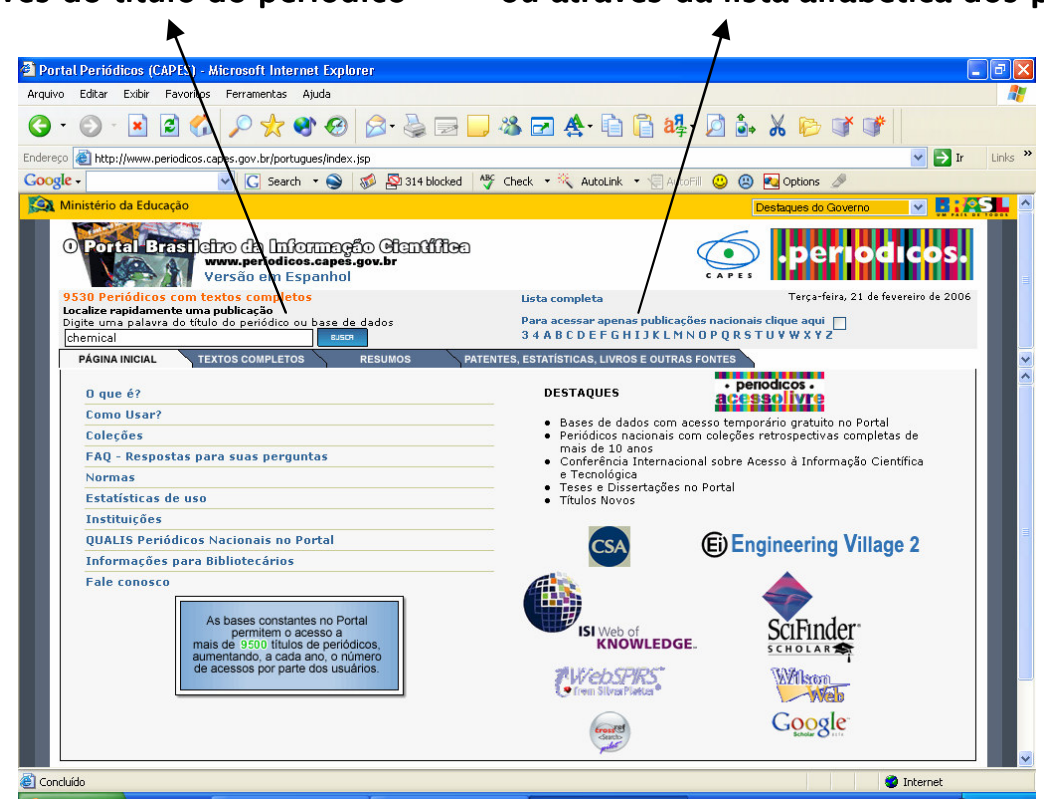

Para localizar rapidamente um periódico, o usuário pode utilizar a opção "Localize rapidamente uma publicação", digitando uma palavra do título do periódico, ou escolher uma letra, na opção "Lista alfabética", para localizar periódicos cujo título seja iniciado com essa letra. Em ambas as opções, após obter uma lista de periódicos, o usuário pode selecionar o título desejado e realizar buscas de artigos diretamente na página da revista. É possível, também, localizar diretamente artigos sobre determinado assunto ou publicados por determinado autor. Este recurso é disponibilizado através das opções "Textos completos" ou "Resumos".

Cabe ainda mencionar que o Portal Capes também disponibiliza os Periódicos de Acesso Livre, que contém além de textos completos, resumos, patentes, teses e dissertações. São cerca de 1.114 títulos de periódicos que podem ser consultados livremente na base.

\section{d) SCOPUS}

É uma base de dados que indexa mais de 14.000 títulos de periódicos, provenientes de 4.000 editoras nas diversas áreas do conhecimento. Seu acesso é realizado através do seguinte endereço na Internet. http://www.scopus.com/scopus/home.url.

O formulário de busca da SCOPUS é semelhante aos de outras bases de dados científicas. As buscas podem ser realizadas através de palavras que compõe o trabalho pesquisado, como palavras do título ou resumos, as próprias palavras-chave, nome dos autores etc. Também é possível restringir as buscas selecionando o período da pesquisa, ou seja, a apresentação de trabalhos apenas a partir de um determinado ano. Como a base SCOPUS dispõe de títulos de periódicos de diversas áreas da Ciência, é possível selecionar a área na qual o usuário deseja restringir sua pesquisa bibliográfica. 
buscas através de palavras que compõe o trabalho

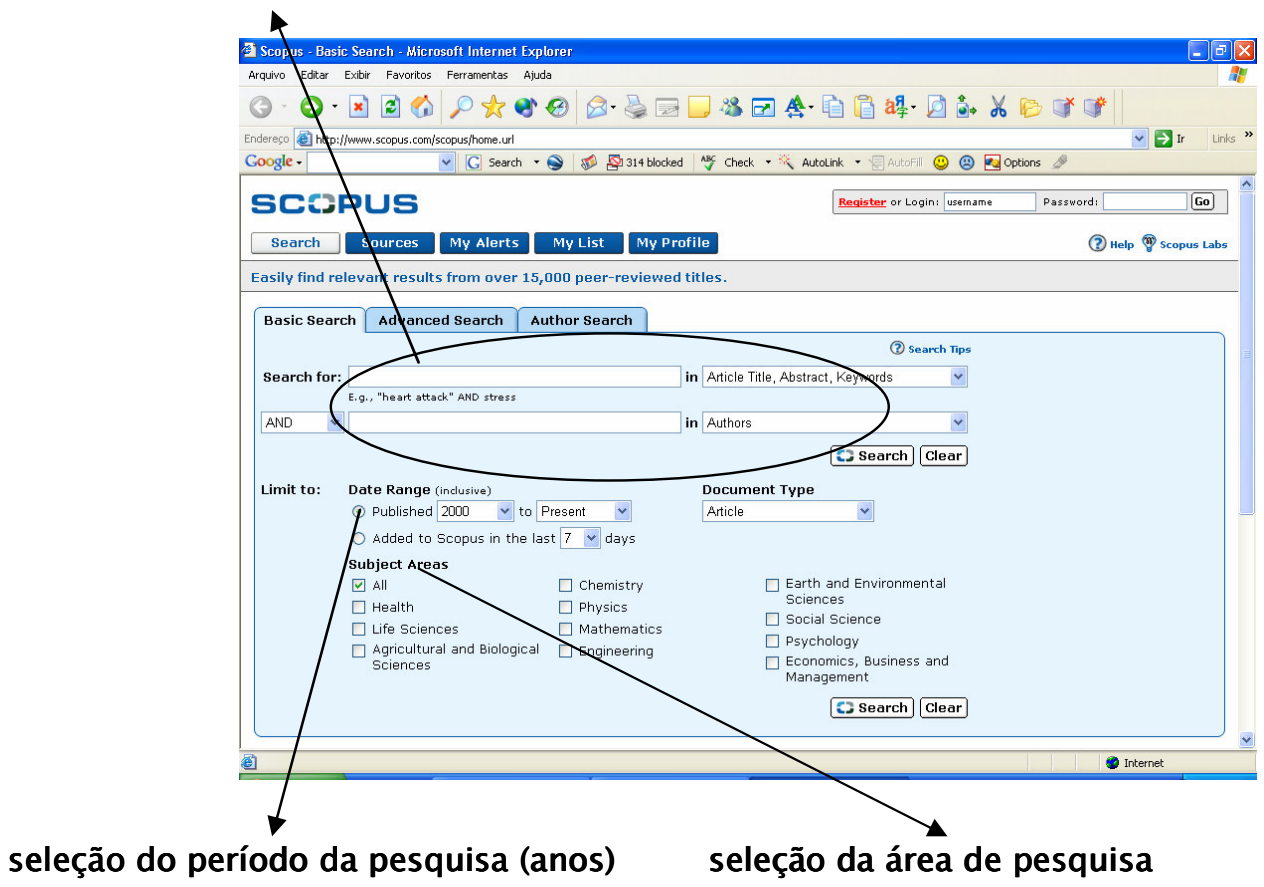

\section{e) ProBE}

O Programa Biblioteca Eletrônica - ProBE, desenvolvido com o objetivo de fornecer apoio ao desenvolvimento da pesquisa científica no Estado de São Paulo, apresenta um acervo de diversos periódicos científicos disponíveis para consulta através do endereço http://probe.bvs.br/index1.php?home=true.

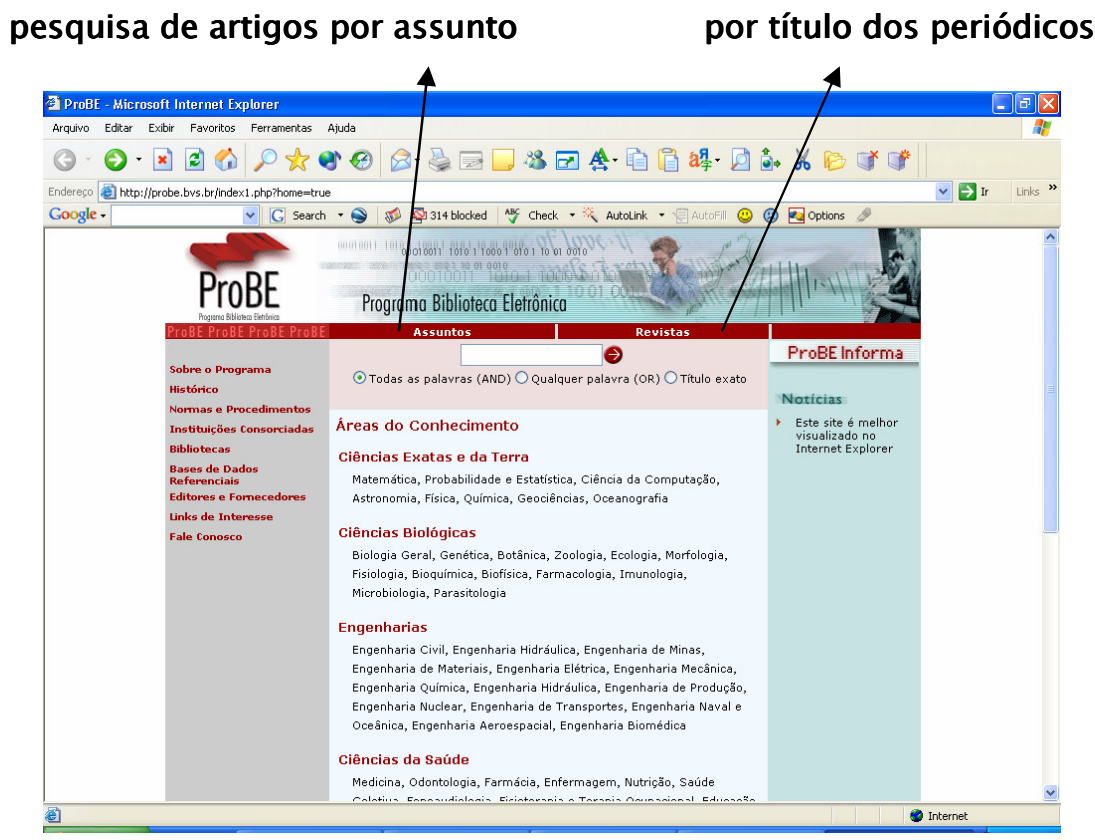


O ProBE disponibiliza:

- 840 títulos de periódicos internacionais da editora Elsevier Science Inc;

- 682 títulos de diferentes editoras das áreas de Humanas, Biológicas e Exatas fornecidos pelo Gale Group;

- 498 títulos das editoras MIT Press, Blackwell Science e Blackwell Publishers, acessíveis via Ebsco Online;

- 114 títulos brasileiros, 39 títulos chilenos, 11 cubanos, 9 venezuelanos, 18 da Costa Rica e 13 da Espanha, no Scielo Scientific Library On-line, com acesso público;

- Títulos da HighWire Press.

\section{f) SIBiNet}

A SibiNet é uma base de dados disponível apenas através de contrato firmado entre a instituição e fornecedores. Seu acesso pode ser realizado através do endereço http://www.sibi.usp.br/sibi/biblioteca/revista/revistas_frm.htm. A base contém atualmente cerca de 10.355 títulos de periódicos.

A pesquisa por artigos na SiBiNet também é realizada a partir da localização do periódicos desejado na lista de títulos apresentada e em ordem alfabética ou simplesmente digitando o nome do periódico na página Após localizar o periódico desejado, o usuário poderá acessar seus artigos publicados.

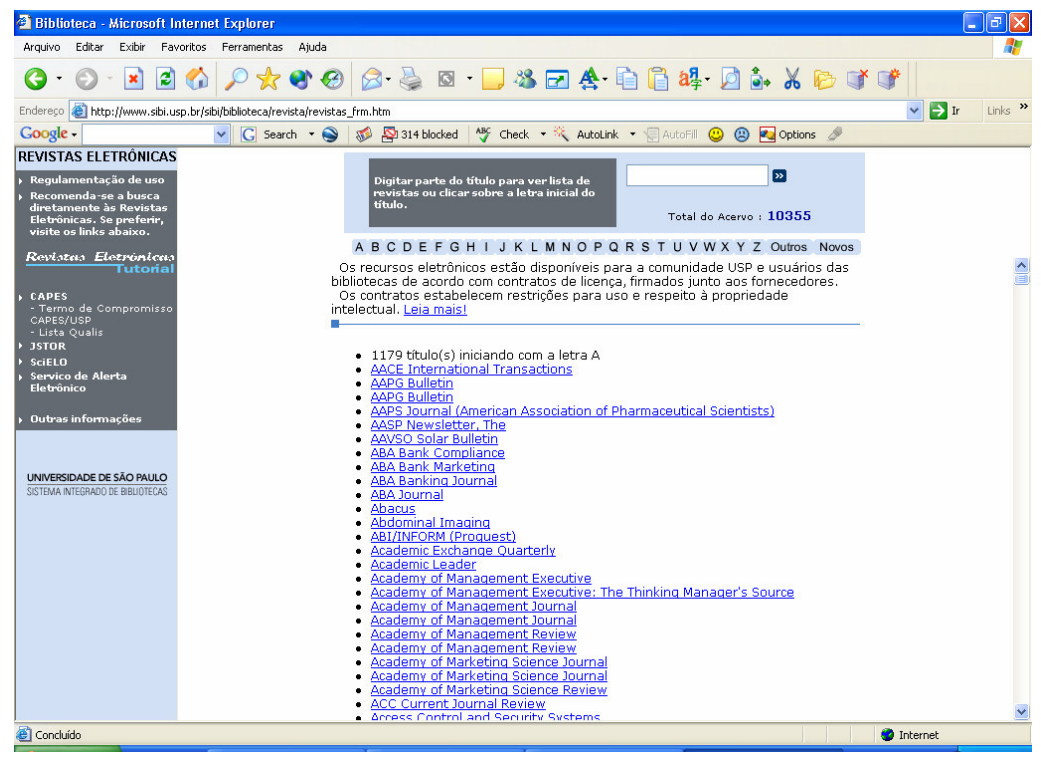

\section{g) Metadex}

Metadex é uma base de dados produzida pela Cambridge Scientific Abstracts, que proporciona ampla cobertura da literatura internacional sobre metais. Corresponde às publicações impressas: Review of Metal Literature, Metals Abstracts, Alloys Index, Steels 
Supplement e Steels Alert. Além de tópicos específicos sobre metais (nomenclatura de ligas específicas, compostos intermetálicos e sistemas metalúrgicos), são cobertas categorias básicas da metalurgia, tais como: materiais, processos, propriedades e produtos.

O formulário de pesquisa da base Metadex também fornece ao usuário opções de buscas através de palavras que compõem o artigo, e de seleção da área e o período de pesquisa.

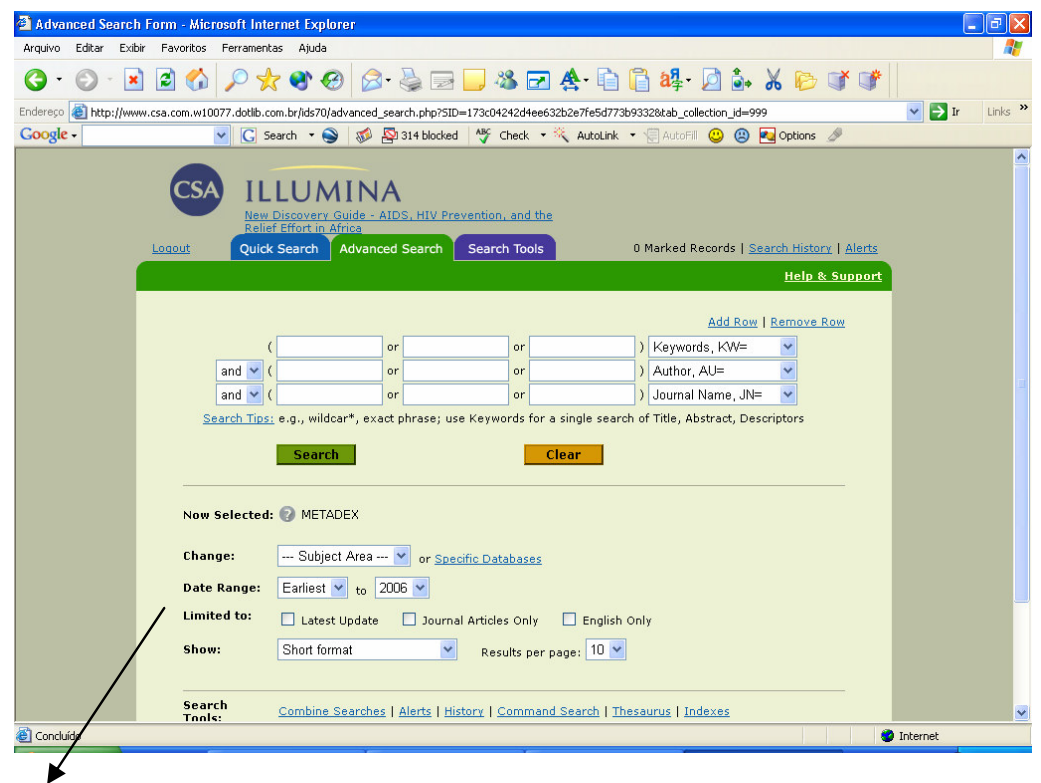

opções de pesquisa por área, período (anos de busca) e tipos de documentos

\section{h) SciFinder Scholar}

SciFinder Scholar é um serviço de acesso à versão eletrônica do Chemical Abstracts, uma base de dados da American Chemical Society (ACS) que cobre a literatura científica publicada na área de Química, de 1907 até o momento. Seu acesso só pode ser realizado a partir de uma assinatura regulamentada. Ou seja, o acesso ao SciFinder Scholar se efetiva a partir da instalação de software específico, fornecido pela American Chemical Society - ACS, nos equipamentos dos usuários assinantes.

As fontes incluem: revistas, patentes, palestras, teses, relatórios técnicos entre outros. O conteúdo cobre áreas, tais como: Engenharia e Química Aplicada, Química Geral, Física, Ciências Médicas, Polímeros, Ciências dos Materiais, etc. A base de dados contém mais de 25 milhões de substâncias orgânicas e inorgânicas, milhões de seqüências de aminoácidos e de proteínas, fontes comerciais de mais de seis milhões de substâncias Químicas e mais de 228 mil registros de substâncias catalogadas em inventários de diversos países. Dispõe de recurso especial que proporciona a busca na base de dados, a partir de estrutura de moléculas e das substâncias, entre outros. 


\author{
DA LINGUAGEM CIENTÍFICA
}

Algumas das principais características da linguagem científica, apresentadas nesta seção, estão relacionadas aos documentos que relatam resultados originais de pesquisa científica. Obviamente artigos de divulgação científica e textos jornalísticos destinados ao público em geral apresentam características diferentes, tais como linguagem menos formal, uso de palavras em sentido figurativo, analogias, entre outras.

\title{
5.1 A LINGUAGEM CIENTIIFICA
}

Embora não específica de textos científicos, outra característica - às vezes determinante na decisão do leitor a apreciar ou mesmo continuar a leitura de um trabalho - é a argumentação. Enfim, é a capacidade de convencer o leitor da importância de um trabalho. Assim o autor costuma demonstrar através das palavras seu poder de persuasão. Esta característica é bem freqüente em projetos de pesquisa no qual o autor costuma apresentar a fim de obter recursos para execução de seu trabalho.

Algumas características são ainda bastante importantes na elaboração de trabalhos científicos, tais como clareza, concisão e continuidade. Estas características na realidade são uma série de cuidados adotados a fim de tornar um texto científico inteligível e agradável. Algumas destas características serão apresentadas a seguir.

\subsubsection{IMPESSOALIDADE}

Uma das características principais dos textos científicos é a impessoalidade. O autor é apenas um observador e descritor dos fatos ocorridos em seu trabalho. Até mesmo as conclusões expostas no texto são baseadas em dados concretos obtidos a partir de sua execução. Portanto, é incomum a ocorrência de verbos na primeira pessoa em textos científicos. Desta forma, os autores costumam optar por verbos na terceira pessoa.

Para tornar o texto impessoal costuma-se utilizar o verbo na voz passiva, seja analítica ou sintética. Ambas são bastante encontradas em trabalhos científicos. Geralmente mantém-se em todo o texto a mesma forma da voz passiva adotada, para garantir homogeneidade nas construções verbais. No exemplo a seguir observa-se a utilização da voz passiva analítica e sintética, respectivamente. 
voz passiva sintética

\section{voz passiva analítica}

A destilaçãe dos solventes foi realizađa sob pressão reduzida [...] Pela análise do espectro DEPT verificou-se que dos seis carbonos aromáticos [...]

(Química Nova, v.27, n.4, 536-539, 2004)

\subsubsection{CLAREZA}

Clareza é definida como a capacidade de transmitir uma idéia com exatidão, evitando que o leitor tenha dúvidas sobre o trabalho. O que pode ser óbvio para o autor pode não ser para o leitor. Além disso, o receio de escrever informações em excesso por achá-las desnecessárias para compreensão do texto, faz com que eventualmente ocorram omissões importantes à clareza de um trabalho. Um texto claro caracteriza-se também pela simplicidade e para tanto os autores evitam utilizar palavras rebuscadas, ambíguas ou abstratas. Desta forma, o uso de palavras no sentido literal não só garantem mais formalidade ao texto e evitam interpretações distintas daquelas desejadas pelo autor.

A clareza, portanto, está diretamente relacionada à exatidão das palavras. Ou seja, as palavras utilizadas no texto devem corresponder exatamente ao seu real significado. Desta forma, os textos científicos costumam evitar ainda o emprego de termos vagos, como por exemplo "uma série", "alguns", "vários" "um pouco" (quantos exatamente?). Observe o exemplo abaixo.

O processo de obtenção de biodiesel a partir do óleo neutro de soja adotado neste trabalho promove uma alta taxa de conversão do óleo em ésteres etílicos [....]. As perdas no processo foram baixas [...]

(Exemplo fictício)

Alta taxa de conversão? 70\%? Perdas baixas? 0,5\%? Um leitor que não conheça bem esta área certamente não saberá que número exatamente pode corresponder a alto ou baixo. Para não deixar a informação obscura, o autor apresenta os dados exatamente como foram obtidos no trabalho, conforme mostra o exemplo a seguir.

O processo de obtenção de biodiesel a partir do óleo neutro de soja adotado neste trabalho promove uma taxa de conversão de $97,5 \%$ do óleo em ésteres etílicos [....]. As perdas no processo foram de $10 \%[\ldots]$

(Quimica Nova, v.28, n.1, 19-23, 2005)

Além da escolha correta de cada palavra, o cuidado na construção das orações também garante clareza ao texto. Orações demasiadamente longas, por exemplo, não costumam ser usadas. O objetivo de orações mais curtas é evitar que o leitor não compreenda bem a idéia apresentada ao ter que lembrar o que foi exposto no início da oração. Observe o exemplo a seguir.

No óleo essencial das folhas foram identificados entre monoterpenos e sesquiterpenos dez componentes representando $99 \%$ da constituição volátil, cujos principais constituintes detectados foram $\beta$-cariofileno (46,5\%), $\alpha$-humuleno $(26,0 \%)$ e $\beta$-pineno $(10,6 \%)$, e nos 
óleos extraídos da casca e do lenho da raiz nenhum monoterpeno foi detectado, por outro lado foram identificados cetonas alifáticas de cadeia longa.

(Exemplo fictício)

Portanto, textos com orações mais curtas tornam a leitura mais agradável e facilitam a compreensão dos várias informações expostas em um mesmo parágrafo, conforme demonstrado nesta versão original.

No óleo essencial das folhas foram identificados dez componentes, entre monoterpenos e sesquiterpenos, representando $99 \%$ da constituição volátil. Os principais constituintes detectados foram $\beta$-cariofileno (46,5\%), $\alpha$-humuleno $(26,0 \%)$ e $\beta$-pineno $(10,6 \%)$. [...] Nos óleos extraídos da casca e do lenho da raiz nenhum monoterpeno foi detectado. Por outro lado foram identificadas cetonas alifáticas de cadeia longa.

(Quimica Nova, v.28, n.1, 57-60, 2005)

A elaboração dos parágrafos também requer cuidados para tornar o texto claro, como, por exemplo, a apresentação das informações em uma seqüência lógica. Esta característica de um texto científico é bastante observada nas seções Materiais e Métodos, onde o autor descreve os procedimentos experimentais na seqüência com que foram realizados.

Após completada a reação, a mistura foi deixada em geladeira por 24 h. A reação foi acompanhada por CCD em sílica (eluente $\mathrm{CHCl}_{3} / \mathrm{MeOH}(9,2: 0,8)$ ). Em seguida, o produto obtido foi filtrado e purificado por sucessivas recristalizações [...]

(Quimica Nova, v. 27, n. 6, 905-910, 2004)

\subsubsection{CONCISÃO}

A concisão em um texto é a capacidade de transmitir uma idéia com o mínimo de palavras, evitando, portanto a prolixidade. É uma habilidade bastante importante na elaboração de textos científicos, sobretudo em artigos científicos, cujos periódicos costumam limitar o número de páginas para publicação. Da mesma forma, trabalhos enviados para congressos também são limitados em número de palavras ou páginas. Assim, é necessário que o autor possa expor claramente os resultados mais importantes de seu trabalho de forma bastante resumida.

Ademais, a concisão está intrinsecamente ligada à objetividade. Os textos científicos costumam concentrar-se no que é essencial e relevante para a exposição dos dados e compreensão do trabalho. Alongar a introdução ou prolongar a discussão, por exemplo, pode fazer com o leitor se perca no texto ou se canse na leitura. Por isso, observa-se que os autores costumam evitar palavras que não agregam informação útil ao texto, como exemplificado abaixo.

Os voltamogramas cíclicos apresentados na Figura 2 mostram os resultados obtidos da polimerização eletroquímica do ácido $2 \mathrm{ABS}$, após a realização de varreduras consecutivas. (Exemplo fictício) 
A nova versão do exemplo anterior, descrita a seguir, mostra que é possível remover palavras em excesso.

A Figura 2 mostra os resultados da polimerização eletroquímica do ácido 2ABS, após varreduras consecutivas.

(Quimica Nova, v. 27, n. 4, 582-585, 2004)

Neste outro exemplo também é possível observar como o autor resume o texto sem remover informações importantes para a sua compreensão.

O estudo químico do caule da espécie Melalenca alternifolia realizada no presente trabalho resultou no isolamento e caracterização de seus constituintes principais, tais como as seguintes substâncias: o ácido 3,3’-O-dimetilelágico...

(Exemplo fictício)

Em sua nova versão:

O estudo químico do caule da Melalenca alternifolia resultou no isolamento e caracterização do ácido 3,3'-O-dimetilelágico [...]

(Quimica Nova, v. 27, v. 4, 536-539, 2004)

O cuidado para não escrever palavras redundantes garante não só a concisão no texto como tornam o trabalho mais elegante. Observa-se que algumas expressões devem ser evitadas, tais como as descritas a seguir:

As pesquisas sobre o óxido nítrico ainda continuam produzindo...

Não tem sido observado um consenso de opinião entre os cientistas...

De acordo com os dados apresentados, concluímos finalmente que....

\subsubsection{CONTINUIDADE}

A continuidade é a capacidade de transmitir as idéias com seqüência lógica, garantindo ao leitor a capacidade de compreender o encadeamento das informações ou interpretações expostas no texto. A continuidade torna a leitura mais fluida e agradável. É uma característica bastante presente em publicações científicas e em todos as suas seções, nas quais parágrafos "ligam-se" a outros ou mesmo uma frase justifica a frase seguinte.

De acordo com o direcionamento lógico que o autor pretende dar às idéias expostas seqüencialmente no texto, observa-se que algumas palavras (geralmente conjunções) ou expressões são características da continuidade, como as descritas a seguir:

- Para expressar explicação ou causa: pois (antes do verbo), devido a, por esse motivo, em decorrência de, visto que;

- Para expressar conclusão: portanto, assim, em resumo; 
- Para expressar oposição: mas, porém, entretanto, por outro lado, no entanto, contudo, todavia etc;

- Para expressar adição: também, ademais, além disso, adicionalmente;

- Para expressar exemplificação: por exemplo, para ilustrar;

- Para expressar similaridade: da mesma forma, igualmente, assim como;

- Para expressar tempo: antes, após, em seguida, previamente, recentemente enquanto, assim que.

$\mathrm{Na}$ seção Introdução, por exemplo, costuma observar-se continuidade nas várias informações descritas pelo autor, interligando uma a outra, a fim de apresentar o tema de seu trabalho e justificar sua importância. O exemplo a seguir demonstra este sequenciamento lógico, tanto entre as frases de um mesmo parágrafo, quanto entre os parágrafos. Observe ainda a presença de "palavras-chave" que dão continuidade ao texto (portanto, nesse contexto, porém, assim, entre essas, visto que).

\section{apresenta-se inicialmente algumas informações que justificam a importância de seu trabalho}

em seguida, dá-se continuidade à idéia iniciada na frase anterior 4

\section{A maior parte de toda energia} e do gás natural. Essas fontes são limitadas e com previsão de esgotamento futuro, portanto, a busca por fontes alternativas de energia é de suma importância. Nesse contexto, os óleos vegetais aparecem como uma alternativa para substituição do óleo diesel em motores de ignição por compressão [...]

Foi constatado, porém, que a aplicação direta dos óleos vegetais nos motores é

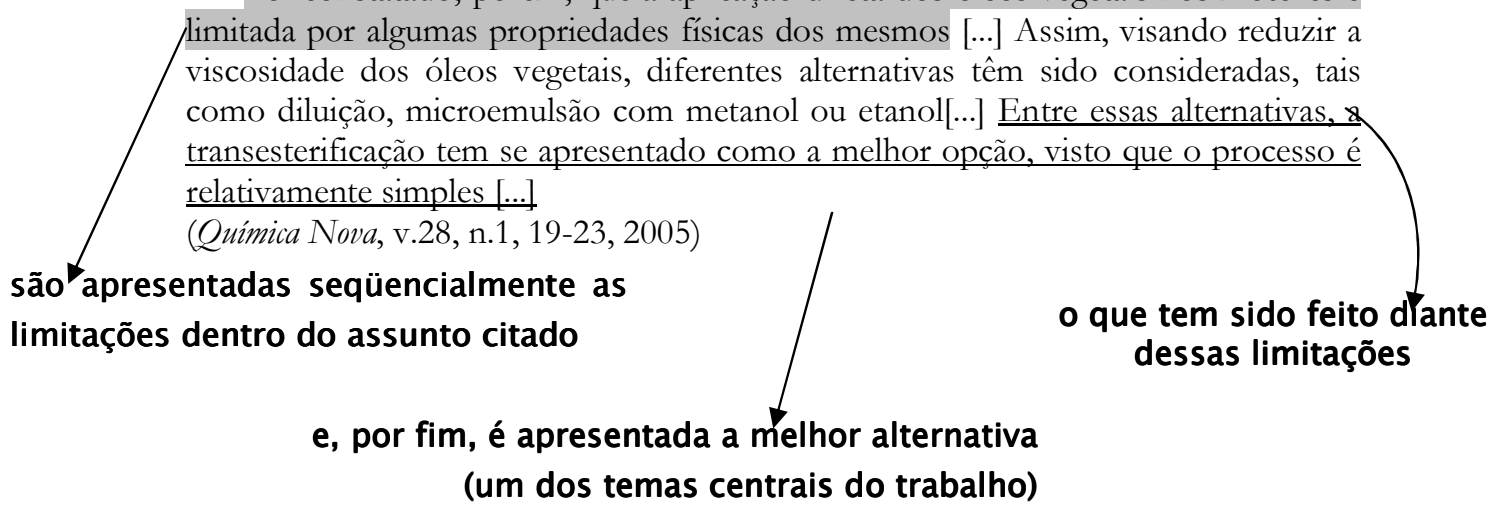

Materiais e Métodos é outra seção de um texto científico na qual a continuidade freqüentemente é observada. É desejável que o autor descreva seqüencialmente todos os procedimentos experimentais realizados exatamente na ordem com que ocorreram. Desta forma, garante que o leitor possa reproduzir os experimentos relatados no trabalho.

Uma solução de $20 \mathrm{~g}$ de (262,78 moles) de tiouréia, 24,8g (262,43 moles) de ácido monocloroacético em $200 \mathrm{~mL}$ de água destilada foi deixada sob agitação e refluxo por 18 horas. Após completada a reação, a mistura foi deixada em geladeira por $24 \mathrm{~h}$. A reação foi 
acompanhada por $\mathrm{CCD}$ em sílica (eluente $\mathrm{CHCl}_{3} / \mathrm{MeOH}(9,2: 0,8)$ ). Em seguida, o produto obtido foi filtrado e purificado por sucessivas recristalizações em água destilada [...].

(Quimica Nova, v. 27, n. 6, 905-910, 2004)

Além da continuidade é importante que o trabalho também apresente unidade. Assim, cada parágrafo costuma descrever uma mesma idéia central. Ao relatar uma outra idéia ou informação, mesmo que tenha alguma relação com a anteriormente exposta, apresenta-se novo parágrafo. Este é o princípio da unidade.

neste parágrafo a idéia central apresentada é a justificativa da importância dos óleos vegetais como fonte de energia alternativa

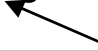

A maior parte de todà energia consumida no mundo provém do petróleo, do carvão e do gás natural. Essas fontes são limitadas e com previsão de esgotamento futuro, portanto, a busca por fontes alternativas de energia é de suma importância. Nesse contexto, os óleos vegetais aparecem como uma alternativa para substituição do óleo diesel em motores de ignição por compressão [...]

Foi constatado, porém, que a aplicação direta dos óleos vegetais nos motores é limitada por algumas propriedades físicas dos mesmos [...] Assim, visando reduzir a viscosidade dos óleos vegetais, diferentes alternativas têm sido consideradas, tais como diluição, microemulsão com metanol ou etanol[...] Entre essas alternativas, a transesterificação tem se apresentado como a melhor opção, visto que o processo é relativamente simples [...]

(Quimica Nova, v.28, n.1, 19-23, 2005)

em outro parágrafo, dando contínuidade ao mesmo assunto, apresenta-se outra idéia (mékodos para reduzir as limitações existentes para utilização dos óleos vegetais em motores)

Em alguns trabalhos científicos é possível observar a divisão do texto em subtópicos, sobretudo em teses e dissertações, cuja revisão de literatura costuma ser extensa e com abordagem de diversos assuntos relacionados ao tema central do trabalho. Desta forma, cada assunto fica separado dos demais (unidade), mas mantém-se o encadeamento lógico (continuidade) entre os parágrafos e entre os tópicos apresentados.

\subsection{OS TEMPOS VERBAIS NOS TEXTOS CIENTÍFICOS}

Os diferentes tempos verbais empregados nos textos científicos obedecem a uma lógica temporal. Ao elaborar um projeto de pesquisa o autor está descrevendo um planejamento de trabalho que pretender realizar e, portanto, sua escrita é feita com verbos no futuro. Por outro lado, um artigo científico descreve uma pesquisa já realizada, por isso os verbos costumam ser apresentados no passado. No entanto, os componentes ou seções de um texto nem sempre apresentam o mesmo tempo verbal em todo seu conteúdo; e mesmo dentro de uma mesma seção é possível ainda observar-se mais de um tempo verbal.

\subsubsection{RESUMOS}


Via de regra, os resumos apresentam fatos já ocorridos. Assim, tanto resumos de congressos quanto resumos presentes em artigos ou dissertações e teses são descritos com verbos conjugados no passado. As conclusões contidas nos resumos podem apresentar verbos no presente. Em alguns casos podem ser observados ainda resumos que descrevem brevemente o assunto abordado e/ou justificativa do trabalho apresentados com verbos conjugados no presente. A seguir podem ser observados resumos de artigo e de congresso, respectivamente.

\section{objetivos e resultados com verbos conjugados nos passado}

Resumo:O objetivo deste trabalho foi caracterizar ácidos húmicos (HA) de diferentes origens por eletroforese capilar de zona [...] Os resultados mostraram que HA de diferentes origens podem ser rapidamente caracterizados por CZE. Por essa técnica, a caracterização de HA é devido a diferenças na razão carga/tamanho e das propriedades dos componentes individuais e duas origens. (Eclet. Química, v. 29, n.2, 47-52, 2004).

conclusão do trabalho com verbo conjugado no presente

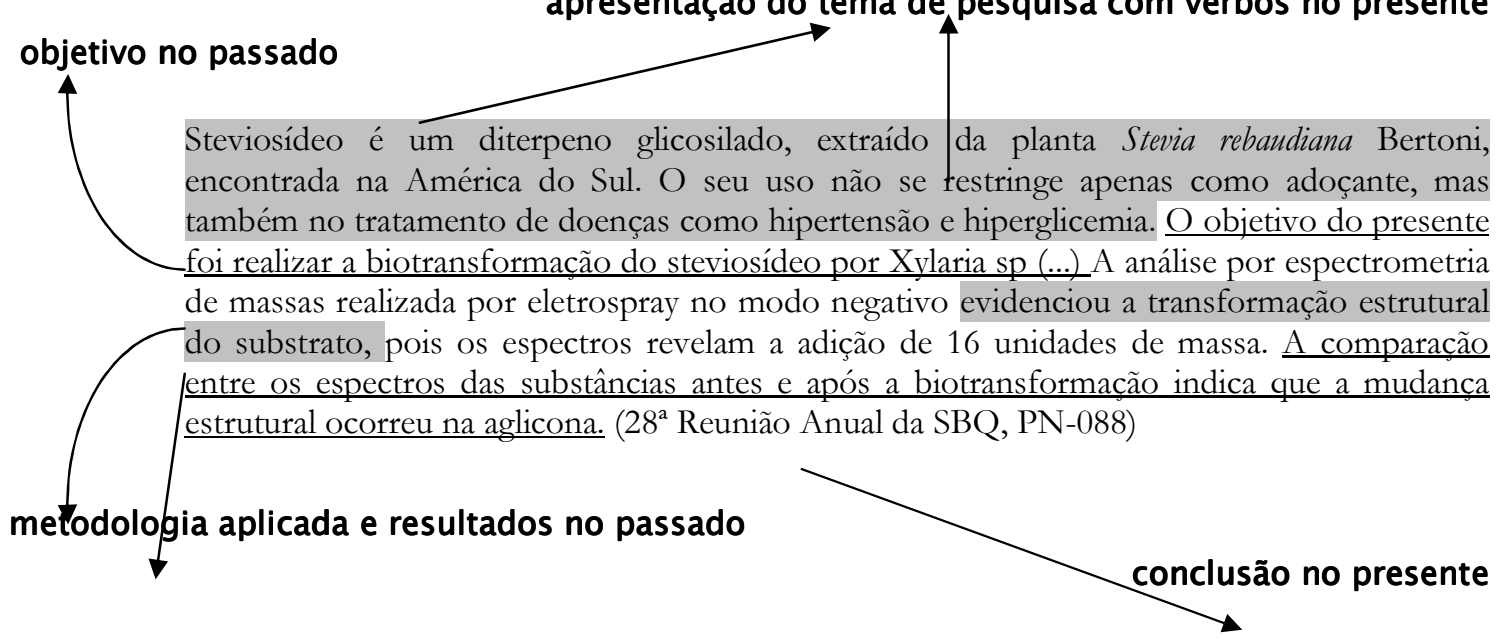

\subsubsection{INTRODUÇÃO}

A introdução de trabalhos científicos pode apresentar vários tempos verbais. Assim, podem ser observados verbos conjugados no presente descrevendo, por exemplo, o tema abordado no trabalho ou sua justificativa. Ou verbos conjugados no passado mostrando resultados de estudos já realizados sobre o mesmo tema. Os objetivos do trabalho podem ser descritos com verbos no presente ou no passado.

Observe este exemplo de introdução reproduzido de um artigo científico: 


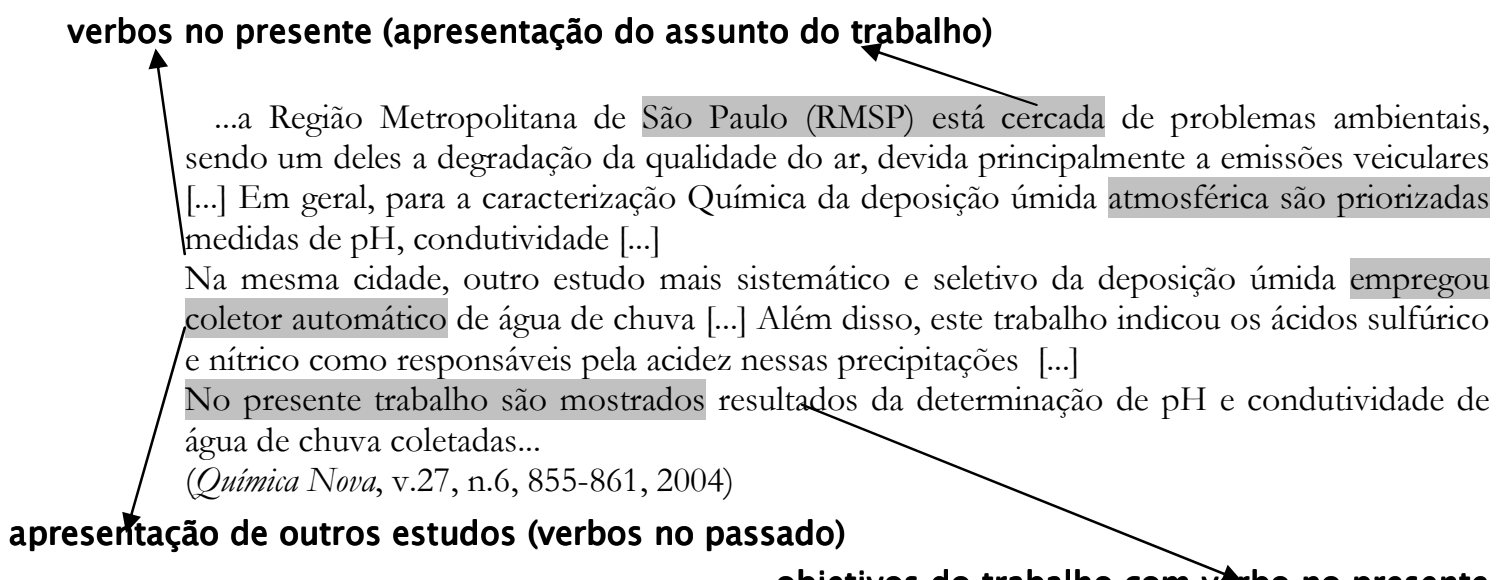

Os objetivos de trabalho apresentado também podem ser descritos com verbos no passado, geralmente em trabalhos concluídos como artigos, dissertações e teses, conforme se observa no exemplo a seguir:

Os objetivos deste trabalho foram realizar a reciclagem de resíduos sólidos pelo processo de síntese de material zeolítico [...]

(Química Nova, v.27, n. 4, 582-585, 2004)

Em projetos de pesquisa, os objetivos em geral são apresentados com verbo no futuro, como demonstra o exemplo abaixo: sólidos...

Neste trabalho será desenvolvida uma nova técnica para a reciclagem de resíduos (Exemplo fictício)

\subsubsection{MATERIAIS E MÉTODOS}

Em artigos, relatórios, teses e dissertações a seção experimental relata fatos já ocorridos, portanto, apresentam verbos conjugados no passado.

Para as preparações cromatográficas em coluna, foram utilizadas sílicas gel 70 e 230 [...] O caule $(3.250 \mathrm{~g})$ e a casca $(700 \mathrm{~g})$, após secagem à temperatura ambiente, foram moídos e submetidos a extrações com hexano [...]

(Química Nova, v. 27, n. 4, 536-539, 2004 - grifo nosso)

Os projetos de pesquisa, no entanto, descrevem trabalhos que ainda não foram realizados - embora na prática já possam ter sido iniciados - e, por esse motivo, os verbos são conjugados no futuro. 
Para as preparações cromatográficas em coluna, serão utilizadas sílicas gel 70 e 230 [...] O caule e a casca, após secagem à temperatura ambiente, serão moídos e submetidos a extrações com hexano $[\ldots]$

(Exemplo adaptado de: Quimica Nova, v. 27, n. 4, 536-539, 2004)

\subsubsection{RESULTADOS}

A seção Resultados descreve os fatos observados ou dados obtidos em um trabalho realizado e, portanto, os verbos são conjugados no passado.

Da casca foram isolados os triterpenos pentacíclicos [...] O composto 1 apresentou em seu espectro de infravermelho, bandas em 3391 e $3185 \mathrm{~cm}^{-1}[\ldots]$

(Quimica Nova, v. 27, n. 4, 536-539, 2004)

As citações no texto de gráficos ou tabelas costumam apresentar-se com verbos no presente, como pode ser demonstrado no seguinte exemplo:

As Figuras 2a e 2b ilustram os cromatogramas de uma solução padrão de cátions [...] Valores das concentrações de MPV e médias aritméticas (desvio padrão), assim como da deposição $\left(\mathrm{mg} \mathrm{m} \mathrm{m}^{-2} \mathrm{mês}^{-1}\right)$ para as espécies analisadas em águas de chuva da região central de São Paulo estão apresentados na Tabela 2.

(Quimica Nova, v. 27, n. 6, 855-861, 2004)

\subsubsection{DISCUSSÃO}

Nesta seção também podem ser observados vários tempos verbais. A interpretação dos resultados é apresentada com verbos no presente ou no passado.

A comparação dos resultados obtidos para os dois conjuntos de precursores mostra diferenças significativas nos valores de massa e espessura estimada, sendo que os filmes preparados a partir de dos sulfatos apresentaram-se bem menos espessos [...] De acordo com os dados obtidos na Tabela 2, pode-se observar que houve um grande aumento no valor de $\Delta$ Ep [...] Essa variação mostra que este eletrodo não tem um comportamento idealmente reversível...

(Quimica Nova, v. 27, n. 6, 866-872, 2004)

A citação de resultados de outros trabalhos já publicados de vê ser realizada com verbos no passado. No entanto, em alguns casos, é possível fazê-la com verbos no presente.

Agarwal e Das igualmente encontraram que 20\% da mistura de biodiesel no óleo diesel, testado em um motor a diesel, teve a melhor performance entre todas as misturas analisadas [...] Já Dourado et al. concluíram que o motor a diesel, analisado sem nenhuma modificação, funciona de maneira bem sucedida com misturas de 10\% 
(Quimica Nova, v. 28, n.1, 19-23, 2005)

No entanto há a possibilidade dos derivados estarem agindo também por inibição da enzima óxido nítrico sintase (NOS) o que, de acordo com Salvemini et al., resulta em diminuição da infiltração neutrofílica no sítio da inflamação...

(Quimica Nova, v. 27, n. 6, 905-910, 2004)

$\mathrm{Na}$ discussão ainda podem ser encontrados verbos no futuro quando o autor faz indicação de trabalhos que ainda serão realizados.

\subsubsection{CONCLUSÕES}

As conclusões, via de regra, também apresentam verbos no passado, quando o autor faz menção aos resultados obtidos no trabalho.

Finalmente, o objetivo de tentar inibir a passivação do Ti durante a etapa térmica de formação do filme de $\mathrm{SnO}_{2}$ platinizando a superfície do titânio foi atingido, pois as densidades de corrente atingidas nestes eletrodos foram até 60 vezes maiores do que quando não platinizada, mostrando viabilidade de seu uso prático.

(Química Nova, v.27, n.6, 866-872, 2004)

É observada ainda a presença de verbos conjugados no presente em Conclusões, o que neste caso faz com que os dados obtidos na pesquisa apresentem-se como concretos e atuais.

Quanto aos parâmetros químicos e físicos analisados pode-se dizer que o biodiesel se apresenta com qualidade de acordo com os limites estabelecidos pela ANP para o óleo diesel comercial e possui predominância de ésteres etílicos de ácidos graxos insaturados em sua composição.

(Quimica Nova, v. 28, n.1, 19-23, 2005)

\subsection{OS JARGÕES CIENTÍFICOS}

Uma dos grandes cuidados ao elaborar um texto científico que seja compreensível para os leitores é evitar o uso de jargões científicos. Os jargões são termos ou frases utilizados no dia-a-dia de laboratório, geralmente bastante conhecidos pelas pessoas da área, mas incorretos quanto ao seu significado literal. A seguir apresentam-se alguns exemplos de jargões bastante comuns na área de Química:

Foram tirados espectros de massa das amostras de...(usual) (exemplo fictício) 


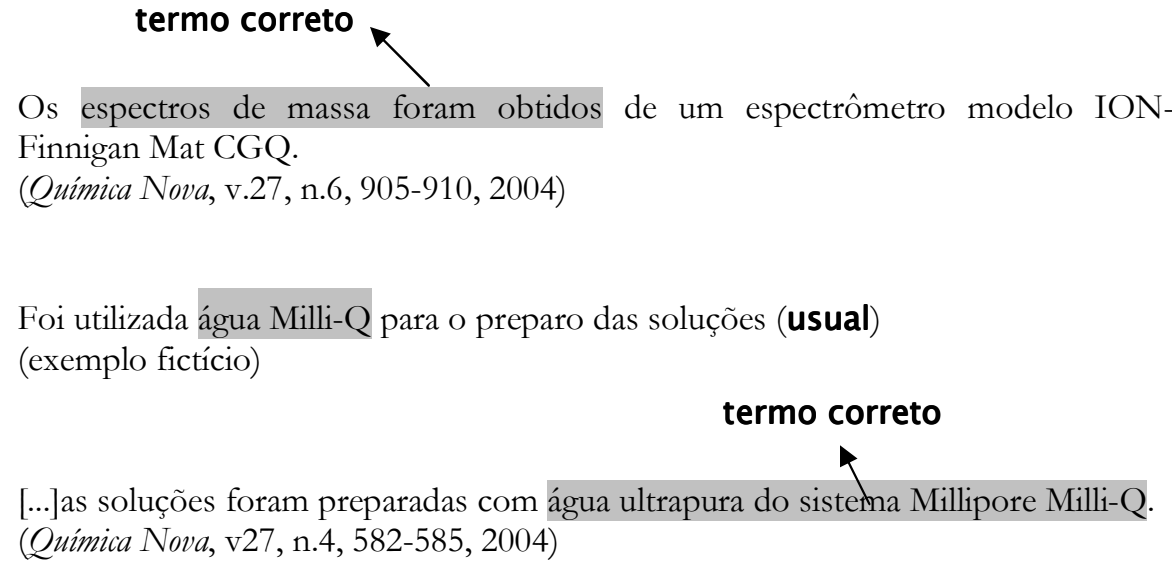

Também é possível localizar termos regionais para substituir o nome correto de um equipamento ou acessório de laboratório, como o descrito no exemplo abaixo:

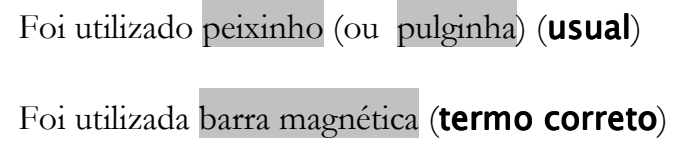

É necessário, porém, que se diferencie os jargões científicos e os termos técnicos, os quais são corretos em sua essência. Os termos técnicos são palavras que resumem um conceito longo que é facilmente compreendido e aceito pelos profissionais da mesma área. Termos técnicos específicos de cada área podem ser facilmente encontrados em textos destinados diretamente aos pares, mesmo sem a descrição detalhada de seu significado. Observe os termos técnicos descritos a seguir.

Estas soluções foram utilizadas para preparar soluções padrão intermediárias, trabalho e para o "spike" em água.

(Quimica Nova, v.27, n.5, 720-724, 2004)

Embora sejam evitados em trabalhos destinados ao público em geral, os termos técnicos eventualmente podem aparecer em tais publicações, desde que seus significados sejam explicados no meio da oração, ou em nota de rodapé (se muito extenso), ou ainda em um glossário (quando forem muito os termos utilizados). Observe o seguinte exemplo:

Sua meia-vida, quando metade do total de moléculas se desfaz, é de apenas cinco segundos.

(Pesquisa Fapesp, n.111, 46-49, 2005) 


\section{6 \\ $B$ \\ IBLIOGRAFIA CONSULTADA}

ABRAHAMSOHN, P. Redação científica. Rio de Janeiro: Guanabara Koogan, 2004, 267p.

ALMEIDA, M. L. P. Como elaborar monografias. Belém: CEJUP, 1996, 224p.

ANDRADE, J.B. A avaliação por pares. Química Nova, v. 28, n. 6, p. 939, 2005.

BENÍTEZ-BRIBIESCA, L.; MODIANO-ESQUENAZI, M. Ethics of science publication after stem cell scandal. Archives of Medical Research, v. 37, p. 423-424, 2006

BUTZ, A. M.; KOHR, L.; JONES, D. Developing a successful poster presentation. Journal of Pediactric Health Care, v. 18, n. 1, p. 45-48, 2004.

CAVALCANTI, B. N.; RODE, S. M. Ética em autoria de trabalhos científicos. Pesquisa Odontológica Brasileira, v. 17, p. 65-66, 2003. Suplemento 1.

CAPES. Critérios para avaliação dos programas de pós-graduação da área de Química. Disponível em: <http://www.capes.gov.br/capes/portal/conteudo/QUIMICA.pdf>. Acesso em: 9 jun 2006.

CONSELHO REGIONAL DE QUÍMICA - IV REGIÃO. Manual de Responsabilidade Técnica. São Paulo: CRQ-IV, 2000, 12p.

CYRANKA, L. F. M.; SOUZA, V. P. Orientações para normalização de trabalhos acadêmicos. Juiz de Fora: Editora da UFJF, 2004, 78p.

GAMA, A. A. S.; FERREIRA, V. F. A pós-graduação em Química no Brasil melhor seus indicadores de qualidade. Química Nova, v. 27, n. 5, p. 687, 2004.

GILPIN, A. A.; PATCHET-GOLUBEV, P. A guide to writing in sciences. Toronto: University of Toronto Press, 1969, 109p.

HERMES-LIMA, M. Publicar e perecer? Ciência Hoje, v. 36, n. 212, p. 76-77, 2005

HUDDLE, P. A. How to present a paper or a poster. Journal of Chemical Education, v. 77, n. 9, p. 1152-1153, 2000.

INSTITUTO DE QUÍMICA DE SÃO CARLOS/ SERVIÇO DE BIBLIOTECA E INFORMAÇÃO. Normas para apresentação de dissertações e teses do IQSC-USP: documentos eletrônicos e impressos. São Carlos: SBI/IQSC, 2005, 80p. 
JACS FACTS. Disponível em: < http://pubs.acs.org/journals/jacsat/promo/facts.pdf> Acesso em: 10 fev 2006.

LATOUR, B.; WOOLGAR, S. A vida de laboratório. Rio de Janeiro: Editora Relume Dumará, 1997, 310p.

LEMOS, A. A. B. Publicar e perecer. Ciência da Informação, v. 34, n. 2, p. 7-8, 2005.

LUZ JÚNIOR, G. E.; SOUSA, S. A.; MOITA, G. C; MOITA NETO, J. M. Química geral experimental: uma nova abordagem didática. Química Nova, vol. 27, n. 1, p. 164 168, 2004.

MARTINS FILHO, P. Direitos autorais na Internet. Ciência da Informação, v. 27, n. 2, p. 183-188, 1998.

McMILLAN, V. E. Writing papers in the biological sciences. 2.ed. Boston: Bedford Books, 1997, p.199.

MEADOWS, A. J. A comunicação científica. Brasília: Briquet de Lemos Livros, 1999, p.263.

MOURA, M. L. S.; FERREIRA, M. C.; PAINE, P. A. Manual para elaboração de projetos de pesquisa. Rio de Janeiro: EdUERJ, 1998, 134p.

NELSON, S. Manual para redação de teses, projetos de pesquisa e artigos científicos. 2.ed. Rio de Janeiro: Guanabara Koogan, 2001, 150p.

OLIVEIRA FILHO, R. S.; HOCHMAN, B.; NAHAS, F. X.; FERREIRA, L. M. Fomento à publicação científica e proteção do conhecimento científico. Acta Cirúrgica Brasileira, v. 20, p. 35-39, 2005. Suplemento 2.

OLIVEIRA, J. P. M.; MOTTA, C. A. P. Como escrever textos técnicos. São Paulo: Pioneira Tomson Learning, 2005, 137p.

PACKER, A. L. ; BIOJONE, M. R.; ANTONIO, I.; TAKENAKA, R. M.; GARCÍA, A. P.; SILVA, A. C.; MURASAKI, R. T.; MYLEK, C.; REIS, O. C.; DELBUCIO, H. C. R. F. SciELO: uma metodologia para publicação eletrônica. Ciência da Informação, v. 27, n. 2, p. 109-121, 1998.

PAULSON, D. R. Writing for chemistry: satisfying the CDU Upper-Division writing requeriment. Journal of Chemical Education, v. 78, n. 8, p. 1047-1049, 2001.

PESSANHA, C. Critérios editoriais de avaliação científica: notas para discussão. Ciência da Informação, v. 27, n. 2, p. 226-229. 1998. 
PETROIANU, Andy. Autoria de um Trabalho Científico. Revista da Associação médica Brasileira, v. 48, n. 1, p. 60-65, 2002.

PINTO, A.C.; ANDRADE, J.B. Fator de impacto de revistas científicas: qual o significado deste parâmetro? Química Nova, v. 22, n. 3, p. 448-453, 1999.

ROSENFELDT, F. L.; DOWLING, J. T.; PEPE, S.; FULLERTON, M. J. How to write a paper for publication. Heart, Lung and Circulation, v. 9, p. 82-87, 2000.

SINGH, B. R.; DECK, J. C. Etiquette in Departmental Seminars. Journal of Chemical Education, v. 75, n. 7, p. 846-848, 1998.

SPECTOR, N. Manual para redação de teses, projetos de pesquisa e artigos científicos, 2.ed. Rio de Janeiro: Guanabara Koogan, 2001, 149p.

UNIVERSIDADE FEDERAL DO PARANÁ/BIBLIOTECA CENTRAL. Normas para apresentação de trabalhos. Parte 2: teses, dissertações e trabalhos acadêmicos. 6.ed. Curitiba: Editora da UFPR, 1996, 23p.

VIEIRA, C. L. Manual de Divulgação Científica: dicas para cientistas e divulgadores de Ciência. 2.ed. Rio de Janeiro: Ciência Hoje/FAPERJ, 1999.

VOGT, C. A espiral da cultura científica. ComCiência, n. 45, 2003. Disponível em: http://www.comciencia.br/reportagens/framereport.htm. Acesso em: 03 maio 2006.

VOLPATO, G. L.; FREITAS, E. G. Desafios da publicação científica. Pesquisa Odontológica Brasileira, v. 17 (supl 1), p. 49-56, 2003. 